ISSN 2313-5891 (Online)

ISSN 2304-974X (Print)

\title{
Ukrainian
}

\section{Food Journal}

\section{Volume 7, Issue 3 \\ 2018}

Kyiv

Київ

2018 
Ukrainian Food Journal is an international scientific journal that publishes innovative papers of the experts in the fields of food science, engineering and technology, chemistry, economics and management.

Ukrainian Food Journal is abstracted and indexed by scientometric databases:
Ukrainian Food Journal - міжнародне наукове періодичне видання для публікації результатів досліджень фахівців у галузі харчової науки, техніки та технології, хімії, економіки і управління.

Ukrainian Food Journal індексується наукометричними базами:

$$
\begin{gathered}
\text { Index Copernicus (2012) } \\
\text { EBSCO (2013) } \\
\text { Google Scholar (2013) } \\
\text { UlrichsWeb (2013) } \\
\text { CABI full text (2014) }
\end{gathered}
$$

Online Library of University of Southern Denmark (2014)

Directory of Research Journals Indexing (DRJI) (2014)

Directory of Open Access scholarly Resources (ROAD) (2014)

European Reference Index for the Humanities and the Social Sciences (ERIH PLUS) (2014)

Directory of Open Access Journals (DOAJ) (2015)

InfoBase Index (2015)

Chemical Abstracts Service Source Index (CASSI) (2016)

FSTA (Food Science and Technology Abstracts) (2018)

Emerging Sourses Citaton Index (2018)

Ukrainian Food Journal включено у перелік наукових фахових видань України з технічних наук (Наказ Міністерства освіти і науки України № 1609 від 21.11.2013)

Editorial office address:

National University of Food Technologies

Volodymyrska str., 68

Ukraine, Kyiv 01601

\section{Адреса редакції:}

Національний університет харчових технологій вул. Володимирська, 68 Київ 01601

\section{e-mail: ufj_nuft@meta.ua}

Scientific Council of the National University of Food Technologies recommends the Journal for printing. Protocol № 2, 27.09.2018
Рекомендовано вченою радою Національного університету харчових технологій. Протокол № 2 від 27.09.2018 p.

(C) HУXT, 2018 
Ukrainian Food Journal publishes original research articles, short communications, scientific news in the related fields and also literature reviews.

\section{Topics coverage:}

Food engineering

Food chemistry

Food microbiology

Physical property of food

Food quality and safety
Food nanotechnologies

Food processing

Economics and management in food industry

Automation of food processes

Food packaging

Periodicity of the journal -4 isues per year.

Reviewing a Manuscript for Publication. All scientific articles submitted for publication in "Ukrainian Food Journal" are double-blind peer-reviewed by at least two academics appointed by the Editors' Board: one from the Editorial Board and one, not affiliated to the Board and/or the Publisher.

Copyright. Authors submitting articles for publication are expected to provide an electronic statement confirming that their work is not an infringement of any existing copyright and will not indemnify the publisher against any breach of legislation and/or international standards in academic publishing. For the ease of dissemination all papers and other contributions become the legal copyright of the publisher unless agreed otherwise.

Academic ethics policy. The Editorial Board of "Ukrainian Food Journal" strictly follows all internationally acknowledged rules and regulations on academic publishing and academic ethics. For more details on this see: Miguel Roig (2003, 2006) "Avoiding plagiarism, self-plagiarism, and other questionable writing practices. A guide to ethical writing". The Editorial Board suggests all potential contributors of the journal, reviewers and readers to dully follow this guidance in order to avoid misconceptions.

For a Full guide for All Authors please visit our website:

$$
\text { http://ufj.ho.ua }
$$




\section{International Editorial Board}

\section{Editor-in-Chief:}

Valerii Mank, Dr., Prof., National University of Food Technologies, Ukraine Members of Editorial board:

Lelieveld Huub, Dr., Global Harmonization Initiative Association, The Netherlands Mark Shamtsyan, Dr., As. Prof, St. Petersburg State Technological Institute, Russia Pascal Dupeux, Dr., University Claude Bernard Lion 1, France Popovici Cristina, Dr., As. Prof., Technical University of Moldova Semih Otles, Dr., Prof., Ege University, Turkey

Sonia Amariei, Dr., Prof., University "Ştefan cel Mare" of Suceava, Romania Stefan Stefanov, Dr., Prof., University of Food Technologies, Bulgaria

Tetiana Pyrog, Dr., Prof., National University of Food Technologies, Ukraine Tomasz Bernat, Dr., Prof., Szczecin University, Poland

Valerii Myronchuk, Dr., Prof., National University for Food Technologies, Ukraine Viktor Stabnikov, Dr., As. Prof., National University for Food Technologies, Ukraine Virginija Jureniene, Dr., Prof., Vilnius University, Lithuania Vladimir Grudanov, Dr., Prof., Belarusian State Agrarian Technical University Volodymyr Ivanov, Dr., Prof., Iowa State University, USA Yordanka Stefanova, Dr., University of Plovdiv "Paisii Hilendarski", Bulgaria Yuliya Dzyazko, Dr., Prof., Institute of General and Inorganic Chemistry «Vernadskii» of National Academy of Sciences of Ukraine

Yurii Bilan, Dr., As. Prof., Szczecin University, Poland

\section{Managing Editor:}

Oleksii Gubenia, Dr., As. Prof., National University of Food Technologies, Ukraine 


\section{Contents}

Merab Jgenti, Levan Gulua, Tamar Turmanidze

Effect of methyl jasmonate, salicylic acid and ascorbic acid on quality parameters of strawberry (Fragaria x ananassa Duch) fruit during cold

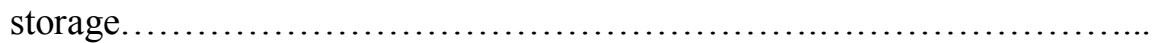

Iryna Tsykhanovska, Lyudmyla Skurikhina,

Victoria Evlash, Larisa Pavlotska

Formation of the functional and technological properties of the beef

minced meat by using the food additive on the nanopowder basis of

double oxide of two- and trivalent iron

Vira Obolkina, Tamara Nosenko,

Olha Dzyhar, Dzhamal Rakhmetov

Chemical composition of fenugreek hay leaves....

Asya Çetinkaya, Fatih $\ddot{O}_{z}$

Changes in cholesterol and free fatty acid content of Kars Gravyer Cheese (A Turkish dairy product produced by the traditional method).

Volodymyr Vyshniak, Oleg Dimitriev,

Svitlana Litvynchuk, Valeriy Dombrovskiy

Identification of beeswax and its falsification

by the method of infrared spectroscopy

Mykola Oseyko, Vasyl Shevchyk, Olena Pokryshko

Antimicrobial properties of model drugs in the systemic concept of

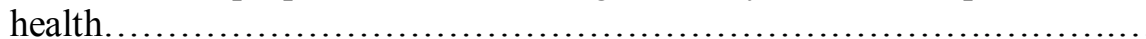

Natalia Povarova, Liudmyla Melnyk

Functional-technological properties of protein composite of animal

origin.

Biotechnology, Microbiology

Anatoli Cartasev

Identification, characterization and industrial utilization of autochthonous strains of Streptococcus thermophilus isolated from Moldavian raw milk and dairy products of spontaneous fermentation 
Food Safety.

Jakia Sultana Jothi, Ishrat Zahan Anka,

Shaharior Hashem, Shamsul Morshed

Assessment of heavy metal concentration in edible fish muscle and water sample collected from different location in Chittagong: a public health concern

Processes and Equipment.

Ihor Mikulionok, Arkadii Petukhov,

Viktor Gapon, Oleksandr Gavva

Intensification of cooling of tubular blown polymeric packing films with the flowing-down liquid film.............................................

Taras Nykytiuk, Valentyn Olishevskiy, Evhen Babko, Oleg Prokopiuk

Impact of nanosized aluminum hydroxide on the structural and mechanical properties of sugar beet tissue.

Oleg Lyashuk, Maria Sokil, Yuriy Vovk, Anna Tson,

Andrii Gupka, Oleksandr Marunych

Torsional oscillations of an auger multifunctional conveyor's screw working body with consideration of the dynamics of a processed medium continuous flow....

Nataliia Lutska, Nataliia Zaiets,

Lidiia Vlasenko, Volodymyr Shtepa

Effective robust optimal control system for a lamellar pasteurizationcooling unit under the conditions of intense external perturbations

Economics and Management

Agota Giedrè Raišiené, Artiom Volkov,

Virgilijus Skulskis, Rita Vilke

Representation of agricultural producers' interests: substantiation of the research construct.

Abstracts.

Instructions for authors. 


\title{
Effect of methyl jasmonate, salicylic acid and ascorbic acid on quality parameters of strawberry (Fragaria $x$ ananassa Duch) fruit during cold storage
}

\author{
Merab Jgenti, Levan Gulua, Tamar Turmanidze
}

Agricultural University of Georgia, Tbilisi, Georgia

\section{Keywords:}

Strawberry

Phenolic

Antioxidant

Anthocyanins

Methyl jasmonate

Salicylic acid,

Ascorbic acid

\section{Article history:}

Received

10.08.2018

Received in

revised form

30.08.2018

Accepted

28.09.2018

Corresponding

author:

Tamar Turmanidze

E-mail:

tturm2010@

agruni.edu.ge

DOI:

$10.24263 / 2304-$

974X-2018-7-3-3

\section{Abstract}

Introduction. The objective of this work was to investigate the combined solution effects of methyl jasmonate, salicylic acid and ascorbic acid on storability of strawberry fruits.

Materials and methods. The anthocyanins were quantified by the $\mathrm{pH}$ differential method. Total phenolic compounds were determined by method using Folin-Ciocalteau reagent. FRAP assay was applied in order to determine antioxidant activity. Determination of individual anthocyanins by HPLC was performed by a Varian- Prostar-500 series liquid chromatograph. The texture analyses of the strawberries were carried out using a Texture Analyser.

Results and discussion. Effect of combined solution of Methyl jasmonate (MJ), Salicylic acid (SA) and Ascorbic acid (AA) on storability of strawberry fruits (Victoria and Camarosa varieties) was investigated. Treatment with $\mathrm{MJ}, \mathrm{SA}$ and $\mathrm{AA}$ positively influenced on the level of content of vitamin $\mathrm{C}$ in strawberries fruits during storage.Total anthocyanins in the control samples of Victoria gradually decreased from $21.35 \pm 1.06$ to $13.35 \pm 0.66 \mathrm{mg} 100 \mathrm{~g}^{-1}$ on the 13-th day of storage. As to the treated samples, anthocyanins content reduced to $15.49 \pm 0.77 \mathrm{mg} 100 \mathrm{~g}^{-1}$. In the samples of Camarosa total anthocyanins reduced from $46.93 \pm 2.34$ to $20.41 \pm 1.02$ and to $34.59 \pm 1.72 \mathrm{mg}$ per $100 \mathrm{~g}$ fruits in control and treated samples respectively.Total phenolic compounds (TPC) in the control samples of Victoria initially was equal to $129.86 \pm 6.49 \mathrm{mglO}^{-1}$ and at the end of experiment, it reduced to $111.15 \pm 5.55 \mathrm{mg} 100 \mathrm{~g}^{-1}$. Whereas, in the treated sample TPC was unchanged. TPC in Camarosa initially was by $40 \%$ more

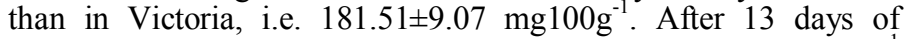
storage, TPC reduced to $131.00 \pm 6.55$ and to $150.02 \pm 7.50 \mathrm{mg}^{100 \mathrm{~g}^{-1}}$ in the control and treated samples respectively. Effect of treatment was statistically and practically significant. During storage period, antioxidant activity of the fruits decreased gradually. Change in antioxidant activity of the treated samples was less significant than in untreated sample. i.e by 17.9 and $23.3 \%$ for the fruits of Victoria and Camarosa varieties respectively. Main anthocyanin in the fruits of both varieties was Pelargonidin-3-O-glucoside. Its initial content in the fruits was $68.45 \pm 3.42$ and $65.28 \pm 3.26 \%$ of total anthocyanins for Victoria and Camarosa varieties respectively.

Conclusion Treatment of fruits of strawberry with combined solutions of methyl jasmonate, salicylic acid and ascorbic acid positively influenced on storability of the fruits. Maintenance of anthocyanins and total phenolics as well as antioxidant potential during storage period was statistically significantly increased. Treatment with combined solution resulted in improvement of texture of fruits during storage process. 


\section{Introduction}

Strawberries (Fragaria $\mathrm{x}$ ananassa Duch) are one of the most popular berries in the world. The quality, chemical composition and sensory parameters of strawberries during fresh storage period have been studied intensively [1]. Strawberries are a good source of vitamins and minerals, and their quality and chemical composition vary among cultivars and with postharvest handling conditions [2]. Also, strawberry fruit is a rich source of natural antioxidants and phytochemicals, particularly anthocyanins, flavonoids, phenolic acids[3-8]. However, shelf life of strawberries is very limited. During fresh storage fruits undergo significant microbial decay, fruit softening, water loss, loss of red color, brown pigment formation, and flavor changes [1,9-10].

Various chemical compounds have been used to treat the strawberry fruits in order to reduce such undesirable changes during storage period and to prolong shelf life of the fruits.

MJ and SA are endogenous plant hormones that play principal roles in regulating stress responses and plant development [11-12].

Methyl jasmonate (MJ)is a plant growth regulator and it very actively participates in many physiological processes $[12,13]$. MJ serves as a signal molecule to initiate the defense mechanism in response to stress conditions [14]. According to Cardemil and coauthors, post-harvest treatments of fruits with jasmonate stimulates the production of such antioxidants as flavonoids, anthocyanins, phenolic acids; improvesthe fruits quality and prolongs their shelf life [15].

Salicylic acid (SA) is a hormonal substance, participating in regulation of numerous physiological processes [16]. SA can inhibit biosynthesis of ethylene in fruits and in such a way delay the ripening of fruits. SA reduces fruit deterioration caused by chill injury and fungal disease during fresh storage period[17].

Ascorbic acid (AA) is known to inhibit browning process in fruits. In addition, AA is cheap and safe for human consumption [18, 19-24].

The objective of our work was to investigate the combined solution effects of methyl jasmonate, salicylic acid and ascorbic acid on storability of strawberry fruits.

\section{Material and methods}

\subsection{Chemicals}

Ascorbic acid higher than $99.0 \%$ and potassium dihydrogen phosphate were purchased from Sigma-Aldrich (Steinheim, Germany); TPTZ - 2-4-6-tris (2-pyridyl)-s-triazine (Sigma-Aldrich, Switzerland), the Folin-Ciocalteau reagent (Appli Chem, Germany), hydrochloric acid, formic acid and phosphoric acid were provided by Merck (Darm-stadt, Germany); sodium carbonate was purchased from ChemCruz (ChemCruz Biochemicals, USA); ethyl acetate and methanol (Sigma-Aldrich, Steinheim, Germany) were HPLC grade. All other reagents were commercially available at the local market and were of analytical grade.

\subsection{Sample collection}

The strawberries (Camarosa and Victoria) were harvested in mid-summer in the eastern part of Georgia (GPS coordinates: Latitude: 4157'59.99” N, Longitude: 4405'60.00” E). After harvesting, representative samples of the fruits were treated with combined solution $(0.005 \% \mathrm{MJ}, 0.15 \% \mathrm{SA}, 1 \% \mathrm{AA})$ at $20 \pm 1{ }^{\circ} \mathrm{C}$ with an exposure time of $2.0 \mathrm{~min}$. The treated 
samples were stored in a refrigerator at $0 \pm 0.5{ }^{\circ} \mathrm{C}$ and $95 \pm 0.5 \%$ RH. Quality parameters such as vitamin $\mathrm{C}$ content, TPC and anthocyanin content, as well as the antioxidant potential were monitored at the start of sampling and after 4,7,10 and 13 days.

\subsection{Sampling procedure}

The samples were prepared for the ascorbic acid determination by HPLC (VarianProstar-500, USA, detector-UV varian Prostar, Australia, column- $250 \mathrm{~mm} \times 4.6 \mathrm{~mm}, \mathrm{dp}=$ $5 \mu \mathrm{m}$ (Symmetry, Waters, Ireland) [25] as follows: briefly, the sample (10 g) was extracted in $10 \mathrm{~mL}$ water adjusted to $\mathrm{pH} 1.5$ with $10 \mathrm{~mL}$ phosphoric acid-water $(2 \%, \mathrm{v} / \mathrm{v})$. The extracts were filtered through $45 \mu \mathrm{m}$ filter paper (Whatman, UK) and $1.5 \mathrm{~mL}$ buffer $(0.01$ $\mathrm{M} \mathrm{KH} 2 \mathrm{PO} 4, \mathrm{pH} 8.0$ ) then added to $1.5 \mathrm{~mL}$ of the sample extract. $1 \mathrm{~mL}$ aliquots (vitamin C) of each of the preferred mixtures were then loaded on to $\mathrm{C} 18$ cartridges (Agilent, Bond Elut, USA) and $3 \mathrm{~mL}$ aliquots of water adjusted to $\mathrm{pH} 1.5$ with $2 \mathrm{~mL}$ phosphoric acid-water $(2 \%, v / v)$ passed through them.

The samples used for the antioxidant analysis were prepared according to RodriguezSaona and Wrolstad (2001) [26]. About $40 \mathrm{~g}$ of strawberries was cryogenically milled in liquid nitrogen. Chilled test tubes were filled with milled fruit powder and weighed $(5 \mathrm{~g})$, and the powder then extracted with acetone $(200 \mathrm{~mL})$.The acetone was removed under vacuum in a rotary evaporator at $<30^{\circ} \mathrm{C}$, and $250 \mathrm{~mL}$ of methanol $(70 \%)$ then added to the powder. The total methanol extract was examined for antioxidant activity.

Samples for anthocyanin analyses by High performance liquid chromatography, HPLC (Varian - Prostar - 500, USA, detector - UV varian Prostar, Australia, column - S $250 \mathrm{x}$ 4.6, Agilent, Microsorb - 100 - 5, The Netherlands) were prepared according to Prior et al. (2012) [27]. Berries ( $40 \mathrm{~g}$ ) were homogenized in methanol/water/formic acid in a ratio of 60: 37: $3(\mathrm{v} / \mathrm{v} / \mathrm{v})$, kept overnight $(14 \mathrm{~h})$ at $3-5^{\circ} \mathrm{C}$ and later filtered by filter $45 \mu \mathrm{m}$ (Whatman, UK) through a Buchner funnel under vacuum. The filtrates were centrifuged $\left(4000 \mathrm{X} \mathrm{g}, 15 \mathrm{~min}, 21^{\circ} \mathrm{C}\right)$ The supernatant was concentrated under vacuum in a rotary evaporator at $<30^{\circ} \mathrm{C}$ to total evaporation of the methanol. An aliquot $(2.0 \mathrm{~mL})$ of the aqueous phase was carefully deposited onto a C - 18 cartridge (Agilent, Bond Elut, USA). sugars and more polar substances were removed by passing $2.0 \mathrm{~mL}$ of ultrapure water through the cartridge. polyphenols were removed by passing $2.0 \mathrm{~mL}$ of ethyl acetate and finally anthocyanin pigments were eluted with $10 \mathrm{~mL}$ of methanol. $10 \mathrm{~mL}$ deionized (DI) water was added to the methanol extract and then the methanol was removed under vacuum in a rotary evaporator at $<30^{\circ} \mathrm{C}$.

\subsection{Determination of $\mathrm{pH}$} [28].

$\mathrm{pH}$ value of the berry fruits was measured using a pH-meter (EHS-320, China) at $20^{\circ} \mathrm{C}$

\subsection{Determination of vitamin $C$}

Vitamin C was determined by the HPLC method [25]. The columns used were $250 \mathrm{~mm}$ $\times 4.6 \mathrm{~mm}, \mathrm{dp}=5 \mu \mathrm{m}$ (Symmetry, Waters, Ireland) and the mobile phase was water adjusted to $\mathrm{pH} 3$ with phosphoric acid. The UV detector (Varian pro Star, Australia) was set at 215 $\mathrm{nm}$ and quantification was based on the peak area measurement. For HPLC (Varian-Prostar-500, USA), $20 \mu \mathrm{L}$ of sample were injected.

\subsection{Determination of total Anthocyanins}

The anthocyanins were quantified by the $\mathrm{pH}$ differential method [29]. Samples were diluted 1:150 in $\mathrm{pH} 1.0$ and $\mathrm{pH} 4.5$ buffers, and the absorbance measured at $520 \mathrm{~nm}$ and $700 \mathrm{~nm}$ in a UV -Visible spectrophotometer (A \& E Lab Co LTD, UK), based on a 
cyanidin 3-glucoside molar extinction coefficient of 26,900 $\Delta \mathrm{Emol}^{-1}$ and a molecular weight of $449.2 \mathrm{gmol}^{-1}$. The resulting values were expressed in terms of $\mathrm{mg}$ of anthocyanin per $100 \mathrm{~g}$ of fresh fruit.

\subsection{Determination TPC}

TPC was performed by Bond et al. (2003) [30]. As aliquot of $1.0 \mathrm{~mL}$ of diluted sample extract was vortexed with $10 \mathrm{~mL}$ DI water and $1.0 \mathrm{~mL}$ Folin-Ciocalteau reagent, and a 1.0 $\mathrm{mL}$ deionized water was used as control. After equilibration at room temperature for $8 \mathrm{~min}$, the solutions were mixed with $4 \mathrm{~mL}$ of $7.5 \%(\mathrm{w} / \mathrm{v}) \mathrm{Na}_{2} \mathrm{CO}_{3}$. The samples and standards (Gallic acid dilute working standard solutions: $10-50 \mu \mathrm{gmL}^{-1}$ ) were equilibrated at room temperature for 60 minutes. The absorbance of the samples and standards were measured spectrophotometrically (UV/Vis spectrophotometer, A\&E Lab Co LTD, UK) at $765 \mathrm{~nm}$, with a $10 \mathrm{~mm}$ path length cell. TPC was calculated as $\mathrm{mg}$ of gallic acid equivalents per 100 $\mathrm{g}$ fresh weight of sample.

\subsection{Determination of individual anthocyanins by HPLC}

Determination of Anthocyanins by HPLC Analyses was performed by a Varian Prostar - 500 series liquid chromatograph. Separation was achieved on a C18, $150 \mathrm{~mm} \times$ $4.6 \mathrm{~mm}$ column. Solvents used were: (A) Aqueous Trifluoroacetic acid (TFA) $0.1 \%$, and (B) Methanol 100\%, establishing the following gradient: isocratic $6 \% \mathrm{~B}$ for $5 \mathrm{~min}, 30 \% \mathrm{~B}$ over $10 \mathrm{~min}$, isocratic $50 \% \mathrm{~B}$ for $15 \mathrm{~min}, 60 \% \mathrm{~B}$ over $5 \mathrm{~min}$, and $6 \% \mathrm{~B}$ over $10 \mathrm{~min}$, using a flow rate of $0.4 \mathrm{~mL}$ min-1, using $518 \mathrm{~nm}$ wavelength, and a mass spectrometer (MS, Varian-prostar-500, USA) connected to the HPLC system. The Mass Spectrometer (MS) was equipped with an Electro Spray Ionization (ESI) source and an ion trap mass analyzer. Spectra were recorded in positive ion mode 3500 volts. Quantification of anthocyanins content was carried out according to chromatographic peaks at $518 \mathrm{~nm}$ wavelength.

\subsection{FRAP assay}

The Ferric Reducing Ability of Plasma (FRAP) assay was carried out as previously described by Benzie and Strain (1996) [31]. The experiment was carried out at $37^{\circ} \mathrm{C}$ and pH 3.6 with a blank sample in parallel. In the FRAP assay, the reductants ("antioxidants") in the sample reduce the $\mathrm{Fe}$ (III)/tripyridyltriazine complex to the blue ferrous form, with an increase in absorbance at $593 \mathrm{~nm}$. The final results were expressed as micromole AA equivalents per 100 gram (mmol AA100g $\left.\mathrm{g}^{-1}\right)$.

\subsection{Texture Profile Analysis (TPA)}

The texture analyses of the strawberries were carried out using a Texture Analyser (LLOYD, TA1, AMETEK Inc, USA).Cylindrical probe with $10 \mathrm{~mm}$ diameter was applied. Extension speed of the probe was $100 \mathrm{mmmin}^{-1}$. Work done by probe, which caused the sample to rupture, was calculated.

\subsection{Statistical Analysis}

The data represents the mean of three replicates \pm standard deviation (SD). Data were subjected to the $t$ - test. All calculations were performed with Microsoft Excel (Version 4, statistical functions, Microsoft Corp., Redmond, WA, USA). 


\section{Results and discussion}

\section{1. pH}

During storage period, $\mathrm{pH}$ value of treated as well as untreated fruits did not change statistically significantly and was between 3.60-3.76 for Victoria (Table 1) and between 3.75-3.99 for Camarosa (Table 2). This fact indicates that there was no hydrolyses of proteins and no change in organic acids concentration during storage period, i.e. conditions for cold storage was chosen properly.

Proximate chemical composition of Victoria

\begin{tabular}{|c|c|c|c|c|c|c|}
\hline \multicolumn{2}{|c|}{$\begin{array}{l}\text { Storage } \\
\text { period }\end{array}$} & pH & $\begin{array}{c}\text { Vitamin C } \\
\text { mg100g }^{-1}\end{array}$ & $\begin{array}{c}\text { Total } \\
\text { Anthocyanins } \\
\operatorname{mg100g}^{-1}\end{array}$ & $\begin{array}{c}\text { TPC } \\
\text { mg100g }^{-1}\end{array}$ & $\begin{array}{c}\text { FRAP mg } \\
\text { equivalents } \\
\text { of vitamin C } \\
\times 100 \mathrm{~g}^{-1}\end{array}$ \\
\hline \multirow{2}{*}{\multicolumn{2}{|c|}{ Initial }} & 3.60 & 45.60 & 21.35 & 129.86 & 206.46 \\
\hline & & $\pm 0.18^{\mathrm{a}}$ & $\pm 2.28^{\mathrm{a}}$ & $\pm 1.06^{\mathrm{a}}$ & $\pm 6.49^{\mathrm{a}}$ & $\pm 10.32^{\mathrm{a}}$ \\
\hline \multirow{4}{*}{$\begin{array}{l}\text { After } 4 \\
\text { days }\end{array}$} & $\mathrm{C}$ & 3.69 & 56.40 & 17.09 & 134.23 & 185.70 \\
\hline & & $\pm 0.18^{\mathrm{a}}$ & $\pm 2.82^{\mathrm{b}}$ & $\pm 0.85^{\mathrm{b}}$ & $\pm 6.71^{\mathrm{a}}$ & $\pm 9.28^{\mathrm{b}}$ \\
\hline & TS & 3.79 & 61.20 & 20.21 & 140.85 & 202.12 \\
\hline & & $\pm 0.19^{\mathrm{a}}$ & $\pm 3.06^{\mathrm{b}}$ & $\pm 1.01^{\mathrm{a}}$ & $\pm 7.04^{\mathrm{a}}$ & $\pm 10.10^{\mathrm{a}}$ \\
\hline \multirow{4}{*}{$\begin{array}{l}\text { After } 7 \\
\text { days }\end{array}$} & $\mathrm{C}$ & 3.68 & 52.80 & 15.79 & 130.92 & 136.08 \\
\hline & & $\pm 0.18^{\mathrm{a}}$ & $\pm 2.64^{\mathrm{b}}$ & $\pm 0.78^{\mathrm{b}}$ & $\pm 5.23^{\mathrm{a}}$ & $\pm 6.80^{\mathrm{c}}$ \\
\hline & TS & 3.80 & 55.20 & 19.50 & 137.56 & 177.25 \\
\hline & & $\pm 0.19^{\mathrm{a}}$ & $\pm 2.76^{\mathrm{b}}$ & $\pm 0.97^{\mathrm{c}}$ & $\pm 6.87^{\mathrm{a}}$ & $\pm 8.86^{\mathrm{b}}$ \\
\hline \multirow{4}{*}{$\begin{array}{l}\text { After } \\
10 \text { days }\end{array}$} & $\mathrm{C}$ & 3.77 & 41.00 & 13.95 & 126.57 & 130.38 \\
\hline & & $\pm 0.17^{\mathrm{a}}$ & $\pm 2.05^{\mathrm{c}}$ & $\pm 0.69^{\mathrm{d}}$ & $\pm 6.32^{\mathrm{a}}$ & $\pm 6.51^{\mathrm{c}}$ \\
\hline & $\mathrm{TS}$ & 3.82 & $49.25 \pm$ & 18.91 & 141.95 & 169.14 \\
\hline & & $\pm 0.20^{\mathrm{a}}$ & $\pm 2.46^{\mathrm{d}}$ & $\pm 0.94^{\mathrm{c}}$ & $\pm 7.10^{\mathrm{a}}$ & $\pm 8.45^{\mathrm{b}}$ \\
\hline \multirow{4}{*}{$\begin{array}{l}\text { After } \\
13 \text { days }\end{array}$} & $\mathrm{C}$ & 3.76 & 22.55 & 13.35 & 111.15 & 120.02 \\
\hline & & $\pm 0.17^{\mathrm{a}}$ & $\pm 1.12^{\mathrm{e}}$ & $\pm 0.66^{\mathrm{d}}$ & $\pm 5.55^{\mathrm{b}}$ & $\pm 6.00^{\mathrm{d}}$ \\
\hline & $\mathrm{TS}$ & 3.95 & 38.95 & 15.49 & 138.00 & 157.61 \\
\hline & & $\pm 0.20^{\mathrm{b}}$ & $\pm 1.94^{\mathrm{f}}$ & $\pm 0.77^{\mathrm{b}}$ & $\pm 6.90^{\mathrm{a}}$ & $\pm 7.88^{\mathrm{e}}$ \\
\hline
\end{tabular}

${ }^{*} \mathrm{C}$-control; **TS-treated samples

*-Values within a column with different letters are significantly different by ANOVA with Tukey's HSD tests at $\mathrm{p}<0.05$.

\subsection{Content of vitamin $\mathrm{C}$}

Vitamin C content in the fruits of Victoria increased after treatment from $45.60 \pm 2.28$ to

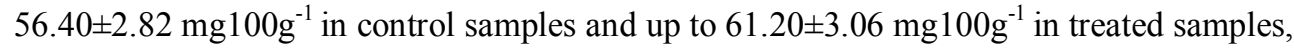
and stayed on this level until 7-th day. Increasing of vitamin $\mathrm{C}$ content was caused, probably, because of the prolonged ripening process in fruits during first storage days [25]. After 7-th day content of vitamin $\mathrm{C}$ declined due to destruction of vitamins caused by oxidation process [32-36]. On the 13-th day, it was $22.55 \pm 1.12$ and $38.95 \pm 1.94 \mathrm{mg} 100 \mathrm{~g}^{-1}$ in control and treated samples respectively. Thus, treatment with MJ, SA and AA positively influenced on the level of content of vitamin $\mathrm{C}$ in Victoria strawberries fruits during storage. 
As to the fruits of Camarosa, because of oxidation process again, vitamin $\mathrm{C}$ content decreased monotonically in the control and treated samples as well, and at the end of experiment it was about half of the initial level. There was no statistically significant difference between content of vitamin $\mathrm{C}$ in the control and treated samples (Table 2). So, in case of Camarosa fruits, no effect of treatment with MJ, SA and AA on the content of vitamin $\mathrm{C}$ was found.

Proximate chemical composition of Camarosa

Table 2

\begin{tabular}{|c|c|c|c|c|c|c|}
\hline \multicolumn{2}{|c|}{$\begin{array}{c}\text { Storage } \\
\text { period }\end{array}$} & pH & $\begin{array}{c}\text { Vitamin } \\
\mathrm{C} \\
\mathrm{mg100g}^{-1}\end{array}$ & $\begin{array}{c}\text { Total } \\
\underset{\text { Anthocyanins }^{-100 g^{-1}}}{\text { mg10 }^{2}}\end{array}$ & $\begin{array}{c}\text { TPC } \\
\text { mg100g }^{-1}\end{array}$ & $\begin{array}{c}\text { FRAP mg } \\
\text { equivalents } \\
\text { vitamin } \mathrm{C} \\
\times 100 \mathrm{~g}^{-1}\end{array}$ \\
\hline \multicolumn{2}{|l|}{ Initial } & $\begin{array}{c}3.75 \\
\pm 0.15^{\mathrm{a}}\end{array}$ & $\begin{array}{c}56.40 \\
\pm 2.82^{\text {a }}\end{array}$ & $\begin{array}{l}46.93 \\
\pm 2.34^{\mathrm{a}}\end{array}$ & $\begin{array}{l}181.51 \\
\pm 9.07^{\mathrm{a}}\end{array}$ & $\begin{array}{c}370.23 \\
\pm 18.51^{\mathrm{a}}\end{array}$ \\
\hline \multirow[t]{2}{*}{$\begin{array}{l}\text { After } 4 \\
\text { days }\end{array}$} & $\mathrm{C}$ & $\begin{array}{c}3.78 \\
\pm 0.15^{\mathrm{a}}\end{array}$ & $\begin{array}{c}58.80 \\
\pm 2.94^{\mathrm{a}}\end{array}$ & $\begin{array}{c}35.03 \\
\pm 1.75^{\mathrm{b}}\end{array}$ & $\begin{array}{l}188.10 \\
\pm 9.40^{\mathrm{a}}\end{array}$ & $\begin{array}{c}352.30 \\
\pm 17.61^{\mathrm{a}}\end{array}$ \\
\hline & TS & $\begin{array}{c}3.82 \\
\pm 0.19^{\mathrm{a}}\end{array}$ & $\begin{array}{c}62.40 \\
\pm 3.12^{\mathrm{a}}\end{array}$ & $\begin{array}{l}48.43 \\
\pm 2.42^{\mathrm{a}}\end{array}$ & $\begin{array}{l}197.80 \\
\pm 9.89^{\mathrm{a}}\end{array}$ & $\begin{array}{c}368.45 \\
\pm 18.42^{\mathrm{a}}\end{array}$ \\
\hline \multirow[t]{2}{*}{$\begin{array}{l}\text { After } 7 \\
\text { days }\end{array}$} & $\mathrm{C}$ & $\begin{array}{c}3.87 \\
\pm 0.18^{\mathrm{a}}\end{array}$ & $\begin{array}{l}43.20 \\
\pm 2.16^{\mathrm{b}}\end{array}$ & $\begin{array}{l}30.15 \\
\pm 1.50^{\mathrm{c}}\end{array}$ & $\begin{array}{l}162.83 \\
\pm 8.14^{\mathrm{b}}\end{array}$ & $\begin{array}{r}281.60 \\
\pm 14.08^{b}\end{array}$ \\
\hline & TS & $\begin{array}{c}3.80 \\
\pm 0.18^{\mathrm{a}}\end{array}$ & $\begin{array}{l}45.60 \\
\pm 2.28^{\mathrm{b}}\end{array}$ & $\begin{array}{l}42.20 \\
\pm 2.11^{\mathrm{a}}\end{array}$ & $\begin{array}{l}184.81 \\
\pm 9.24^{\mathrm{a}}\end{array}$ & $\begin{array}{c}319.99 \\
\pm 15.99^{c}\end{array}$ \\
\hline \multirow[t]{2}{*}{$\begin{array}{l}\text { After } 10 \\
\text { days }\end{array}$} & $\mathrm{C}$ & $\begin{array}{c}3.90 \\
\pm 0.19^{\mathrm{a}}\end{array}$ & $\begin{array}{r}28.70 \\
\pm 1.43^{\mathrm{c}}\end{array}$ & $\begin{array}{c}26.28 \\
\pm 1.31^{\mathrm{d}}\end{array}$ & $\begin{array}{l}160.32 \\
\pm 8.01^{\mathrm{b}}\end{array}$ & $\begin{array}{c}216.30 \\
\pm 10.81^{d}\end{array}$ \\
\hline & $\mathrm{TS}$ & $\begin{array}{c}3.84 \\
\pm 0.19^{\mathrm{a}}\end{array}$ & $\begin{array}{c}30.75 \\
\pm 1.53^{\mathrm{c}}\end{array}$ & $\begin{array}{c}38.17 \\
\pm 1.90^{\mathrm{b}}\end{array}$ & $\begin{array}{l}180.11 \\
\pm 9.00^{\mathrm{a}}\end{array}$ & $\begin{array}{c}277.98 \\
\pm 13.89^{\mathrm{b}}\end{array}$ \\
\hline \multirow[t]{2}{*}{$\begin{array}{l}\text { After } 13 \\
\text { days }\end{array}$} & $\mathrm{C}$ & $\begin{array}{c}3.99 \\
\pm 0.20^{\mathrm{a}}\end{array}$ & $\begin{array}{l}23.40 \\
\pm 1.17^{\mathrm{d}}\end{array}$ & $\begin{array}{l}20.41 \\
\pm 1.02^{\mathrm{e}}\end{array}$ & $\begin{array}{l}131.00 \\
\pm 6.55^{\mathrm{c}}\end{array}$ & $\begin{array}{c}201.14 \\
\pm 10.05^{\mathrm{d}}\end{array}$ \\
\hline & TS & $\begin{array}{c}3.83 \\
\pm 0.18^{\mathrm{a}}\end{array}$ & $\begin{array}{l}25.42 \\
\pm 2.27^{\mathrm{d}}\end{array}$ & $\begin{array}{c}34.59 \\
\pm 1.72^{\mathrm{b}}\end{array}$ & $\begin{array}{l}150.02 \\
\pm 7.50^{\mathrm{d}}\end{array}$ & $\begin{array}{c}248.25 \\
\pm 12.41^{\mathrm{e}}\end{array}$ \\
\hline
\end{tabular}

*C-control; **TS-treated samples

*-Values within a column with different letters are significantly different by ANOVA with Tukey's HSD tests at $\mathrm{p}<0.05$.

\subsection{Content of total anthocyanins}

Total anthocyanins in the control samples of Victoria gradually decreased from $21.35 \pm 1.06$ to $13.35 \pm 0.66 \mathrm{mg} 100 \mathrm{~g}^{-1}$ on the 13 -th day of storage. The reason for reduction of anthocyanins quantity may be their oxidation process [37]. As to the treated samples, anthocyanins content reduced to $15.49 \pm 0.77 \mathrm{mg} 100 \mathrm{~g}^{-1}$. Difference between control and treated samples at the end of experiment was statistically significant but practically insignificant (Table 1).

In the samples of Camarosa total anthocyanins reduced from $46.93 \pm 2.34$ to $20.41 \pm 1.02$ and to $34.59 \pm 1.72 \mathrm{mg}$ per $100 \mathrm{~g}$ fruits in control and treated samples respectively. Difference between control and treated samples at the end of experiment was statistically and practically significant as well (Table 2). Thus, in case of Camarosa, application of combined solution of methyl jasmonate, salicylic acid and ascorbic acid positively influenced on storability of strawberry fruits. 


\subsection{TPC}

Total phenolic compounds in the control samples of Victoria initially was equal to $129.86 \pm 6.49 \mathrm{mg} 100 \mathrm{~g}^{-1}$ and at the end of experiment it reduced to $111.15 \pm 5.55$, that is by $17 \%$. Degradation of phenolic compounds was. Probably, caused by their oxidation [38.39]. Whereas, in the treated sample TPC was unchanged (Table 1), assumingly due to the treatment effect.

TPC in Camarosa initially was by $40 \%$ more than in Victoria, i.e. $181.51 \pm 9.07$ $\mathrm{mg} 100 \mathrm{~g}^{-1}$. After 13 days of storage, TPC reduced to $131.00 \pm 6.55$ and to $150.02 \pm 7.50$ $\mathrm{mg} 100 \mathrm{~g}^{-1}$ in the control and treated samples respectively (Table 2). Effect of treatment was statistically and practically significant. From these data, we can conclude, that combined solution of MJ, SA and AA effectively inhibited oxidation process of phenolic compounds in the fruits of strawberry of Victoria and Camarosa varieties.

\subsection{FRAP assay}

It is well known that antioxidant activity of fruits is proportional to the phenolic compounds content [40.41]. Therefore, it was not surprising that antioxidant activity monotonically decreased in the control samples of Victoria from $206.46 \pm 10.32$ at the first day to $120.02 \pm 6.00 \mathrm{mg}$ equivalents of vitamin-C per $100 \mathrm{~g}$ fruits at the end of the experiment. Change in antioxidant activity of the treated samples of Victoria was less significant: from $206.46 \pm 10.32$ to $157.61 \pm 7.88$ units, that is by $17.9 \%$ less than in the case of control samples.

Antioxidant activity of fruits of Camarosa initially was by $80 \%$ more than that of Victoria fruits. During storage period, antioxidant activity of the fruits of Camarosa decreased gradually. After 13 days of storage, it was equal to $201.14 \pm 10.05$ and $248.25 \pm 12.41$ units for untreated and treated samples respectively (Table 2). Thus, the effect of treatment was statistically and practically significant, i.e. $23.3 \%$.

\subsection{Individual anthocyanins}

Main anthocyanin in the fruits of both varieties was Pelargonidin-3-O-glucoside. This is a common case for strawberry fruits [42]. Its initial content in the fruits was $68.45 \pm 3.42$ and $65.28 \pm 3.26 \%$ of total anthocyanins for Victoria and Camarosa varieties respectively. Though total anthocyanins content gradually decreased during storage period, percentage of this anthocyanin did not change during storage days (Table 3). This indicates on the fact, that Pelargonidin-3-O-glucoside remained the main anthocyanin during whole period of storage. In Victoria variety Pelargonidin-3-acetyl-glucoside was the second anthocyanin by quantity - its percentage in the treated and untreated samples was about $10 \%$ and did not changed during storage. Percentage of this anthocyanin in the Camarosa variety varied nonmonotonically during storage time. Non-monotonical changes of percentage of individual anthocyanins, assumingly, was a result of the fact that quantity of various anthocyanins were changing differently during storage period. In Camarosa Cyanidin-3-O-glucoside was the second anthocyanin by quantity, its percentage changed during storage period from $10.25 \pm 0.51$ to $9.41 \pm 0.47$ and $8.10 \pm 0.40 \%$ for untreated and treated fruit samples respectively. Pelargonidin-3-O- rutinoside was one more anthocyanins detected in both varieties of strawberry. Its initial percentage was equal to $6.14 \pm 0.30$ and $8.23 \pm 0.41 \%$ in Victoria and Camarosa varieties respectively. Cyanidin-3-O-rutinoside was presented in the smallest quantity in both varieties. Its percentage was less than $1 \%$ and did not change practically during storage time. 
Table 3

Individual Anthocyanins in Strawberry cultivars (\%)

\begin{tabular}{|c|c|c|c|c|c|c|c|}
\hline Cultivars & \multicolumn{2}{|c|}{ Storage period } & 1 & 2 & 3 & 4 & 5 \\
\hline \multirow{10}{*}{ Victoria } & \multicolumn{2}{|l|}{ Initial } & 5.44 & 0.17 & 68.45 & 6.14 & 10.03 \\
\hline & \multirow{3}{*}{ After 4 days } & ${ }^{2}$ & 520 & 021 & 6004 & 76,5 & 083 \\
\hline & & $C$ & $\begin{array}{c}5.39 \\
\pm 0.26^{\mathrm{a}}\end{array}$ & $\pm 0.01^{\mathrm{b}}$ & $\begin{array}{l}69.04 \\
\pm 3.45^{\mathrm{a}}\end{array}$ & $\begin{array}{c}1.65 \\
\pm 0.38^{b}\end{array}$ & $\begin{array}{l}9.83 \\
\pm 0.49^{\mathrm{a}}\end{array}$ \\
\hline & & TS & $\begin{array}{c}6.30 \\
\pm 0.31^{\mathrm{b}}\end{array}$ & $\begin{array}{c}0.19 \\
\pm 0.009^{\mathrm{c}}\end{array}$ & $\begin{array}{c}69.19 \\
\pm 3.46^{\mathrm{a}}\end{array}$ & $\begin{array}{c}6.45 \\
\pm 0.32^{\mathrm{a}}\end{array}$ & $\begin{array}{c}9.13 \\
\pm 0.45^{\mathrm{a}}\end{array}$ \\
\hline & \multirow{2}{*}{ After 7 days } & $\mathrm{C}$ & $\begin{array}{c}7.71 \\
\pm 0.38^{\mathrm{c}}\end{array}$ & $\begin{array}{c}0.23 \\
\pm 0.01^{\mathrm{d}}\end{array}$ & $\begin{array}{c}65.95 \\
\pm 3.29^{\mathrm{a}}\end{array}$ & $\begin{array}{c}7.44 \\
\pm 0.37^{b}\end{array}$ & $\begin{array}{c}10.33 \\
\pm 0.51^{\mathrm{a}}\end{array}$ \\
\hline & & TS & $\begin{array}{c}6.76 \\
\pm 0.33^{\mathrm{b}}\end{array}$ & $\begin{array}{c}0.22 \\
\pm 0.01^{\text {bd }}\end{array}$ & $\begin{array}{c}66.87 \\
\pm 3.34^{\mathrm{a}}\end{array}$ & $\begin{array}{c}6.59 \\
\pm 0.32^{\mathrm{a}}\end{array}$ & $\begin{array}{c}10.06 \\
\pm 0.50^{\mathrm{a}}\end{array}$ \\
\hline & \multirow{2}{*}{ After 10 days } & $\mathrm{C}$ & $\begin{array}{c}5.23 \\
\pm 0.26^{\mathrm{a}}\end{array}$ & $\begin{array}{c}0.20 \\
\pm 0.02^{\mathrm{bd}}\end{array}$ & $\begin{array}{c}69.45 \\
\pm 3.47^{\mathrm{a}}\end{array}$ & $\begin{array}{c}6.12 \\
\pm 0.30^{\mathrm{a}}\end{array}$ & $\begin{array}{c}8.09 \\
\pm 0.40^{\mathrm{b}}\end{array}$ \\
\hline & & TS & $\begin{array}{c}6.19 \\
\pm 0.38^{\mathrm{a}}\end{array}$ & $\begin{array}{c}0.24 \\
\pm 0.01^{\mathrm{d}}\end{array}$ & $\begin{array}{c}68.01 \\
\pm 3.40^{\mathrm{a}}\end{array}$ & $\begin{array}{c}7.33 \\
\pm 0.36^{\mathrm{b}}\end{array}$ & $\begin{array}{c}9.38 \\
\pm 0.47^{\text {a }}\end{array}$ \\
\hline & \multirow{2}{*}{ After 13 days } & $\mathrm{C}$ & $\begin{array}{c}8.27 \\
\pm 0.41^{\mathrm{c}}\end{array}$ & $\begin{array}{c}0.23 \\
\pm 0.01^{\text {bd }}\end{array}$ & $\begin{array}{c}66.29 \\
\pm 3.31^{\mathrm{a}}\end{array}$ & $\begin{array}{c}6.02 \\
\pm 0.30^{\mathrm{b}}\end{array}$ & $\begin{array}{c}8.22 \\
\pm 0.41^{\mathrm{b}}\end{array}$ \\
\hline & & TS & $\begin{array}{c}8.69 \\
\pm 0.43^{\mathrm{c}}\end{array}$ & $\begin{array}{c}0.35 \\
\pm 0.02^{\mathrm{e}}\end{array}$ & $\begin{array}{c}64.84 \\
\pm 3.24^{\mathrm{a}}\end{array}$ & $\begin{array}{c}5.47 \\
\pm 0.27^{\mathrm{c}}\end{array}$ & $\begin{array}{c}9.10 \\
\pm 0.45^{\mathrm{a}}\end{array}$ \\
\hline \multirow{9}{*}{ Camarosa } & \multicolumn{2}{|l|}{ Initial } & $\begin{array}{c}9.28 \\
\pm 0.46^{\mathrm{a}}\end{array}$ & $\begin{array}{c}0.48 \\
\pm 0.02^{\mathrm{a}}\end{array}$ & $\begin{array}{c}65.28 \\
\pm 3.26^{\mathrm{a}}\end{array}$ & $\begin{array}{c}8.23 \\
\pm 0.41^{\mathrm{a}}\end{array}$ & $\begin{array}{c}7.01 \\
\pm 0.35^{\mathrm{a}}\end{array}$ \\
\hline & \multirow{2}{*}{ After 4 days } & $\mathrm{C}$ & $\begin{array}{c}10.25 \\
\pm 0.51^{\text {a }}\end{array}$ & $\begin{array}{c}0.63 \\
\pm 0.03^{\mathrm{b}}\end{array}$ & $\begin{array}{c}65.40 \\
\pm 3.27^{\mathrm{a}}\end{array}$ & $\begin{array}{c}11.71 \\
\pm 0.58^{b}\end{array}$ & $\begin{array}{c}3.13 \\
\pm 0.15^{\mathrm{b}}\end{array}$ \\
\hline & & TS & $\begin{array}{c}7.81 \\
\pm 0.39^{b}\end{array}$ & $\begin{array}{c}0.46 \\
\pm 0.02^{\mathrm{a}}\end{array}$ & $\begin{array}{c}68.68 \\
\pm 3.43^{\mathrm{a}}\end{array}$ & $\begin{array}{c}8.72 \\
\pm 0.43^{\mathrm{a}}\end{array}$ & $\begin{array}{c}4.12 \\
\pm 0.20^{\mathrm{c}}\end{array}$ \\
\hline & \multirow{2}{*}{ After 7 days } & $\mathrm{C}$ & $\begin{array}{c}9.29 \\
\pm 0.46^{\mathrm{a}}\end{array}$ & $\begin{array}{c}0.70 \\
\pm 0.03^{\mathrm{c}}\end{array}$ & $\begin{array}{c}65.50 \\
\pm 3.27^{\mathrm{a}}\end{array}$ & $\begin{array}{c}13.93 \\
\pm 0.69^{\mathrm{c}}\end{array}$ & $\begin{array}{c}1.57 \\
\pm 0.07^{\mathrm{d}}\end{array}$ \\
\hline & & TS & $\begin{array}{c}10.58 \\
\pm 0.52^{\mathrm{a}}\end{array}$ & $\begin{array}{c}0.59 \\
\pm 0.03^{\mathrm{b}}\end{array}$ & $\begin{array}{c}64.00 \\
\pm 3.20^{\mathrm{a}}\end{array}$ & $\begin{array}{c}10.67 \\
\pm 0.53^{\mathrm{b}}\end{array}$ & $\begin{array}{c}4.62 \\
\pm 0.23^{\mathrm{e}}\end{array}$ \\
\hline & \multirow{2}{*}{ After 10 days } & $\mathrm{C}$ & $\begin{array}{c}11.41 \\
\pm 0.57^{\mathrm{a}}\end{array}$ & $\begin{array}{c}0.65 \\
\pm 0.03^{\mathrm{b}}\end{array}$ & $\begin{array}{c}65.81 \\
\pm 3.29^{\mathrm{a}}\end{array}$ & $\begin{array}{c}10.08 \\
\pm 0.50^{\mathrm{b}}\end{array}$ & $\begin{array}{c}2.23 \\
\pm 0.11^{\mathrm{f}}\end{array}$ \\
\hline & & TS & $\begin{array}{c}9.12 \\
\pm 0.45^{\mathrm{a}}\end{array}$ & $\begin{array}{c}0.31 \\
\pm 0.01^{\mathrm{d}}\end{array}$ & $\begin{array}{c}62.73 \\
\pm 3.13^{\mathrm{a}}\end{array}$ & $\begin{array}{c}4.11 \\
\pm 0.20^{\mathrm{d}}\end{array}$ & $\begin{array}{c}12.26 \\
\pm 0.61^{\mathrm{g}}\end{array}$ \\
\hline & \multirow{2}{*}{ After 13 days } & $\mathrm{C}$ & $\begin{array}{c}9.41 \\
\pm 0.47^{\mathrm{a}}\end{array}$ & $\begin{array}{c}0.62 \\
\pm 0.03^{\mathrm{b}}\end{array}$ & $\begin{array}{c}67.81 \\
\pm 3.39^{\mathrm{a}}\end{array}$ & $\begin{array}{c}10.16 \\
\pm 0.50^{b}\end{array}$ & $\begin{array}{c}2.02 \\
\pm 0.10^{\mathrm{f}}\end{array}$ \\
\hline & & $\mathrm{TS}$ & $\begin{array}{c}8.10 \\
\pm 0.40^{b}\end{array}$ & $\begin{array}{c}0.32 \\
\pm 0.01^{\mathrm{d}}\end{array}$ & $\begin{array}{c}63.73 \\
\pm 3.18^{\mathrm{a}}\end{array}$ & $\begin{array}{c}4.00 \\
\pm 0.20^{\mathrm{d}}\end{array}$ & $\begin{array}{c}11.30 \\
\pm 0.56^{\mathrm{g}}\end{array}$ \\
\hline
\end{tabular}

*C-control; **TS-Treated samples

1.Cyanidin-3-O-glucoside

2.Cyanidin-3-O-rutinoside

3.Pelargonidin-3-O-glucoside

4.Pelargonidin-3-O- rutinoside

5.Pelargonidin-3-acetyl-glucoside

* Values within a column with different letters are significantly different by ANOVA with Tukey's HSD tests at $\mathrm{p}<0.05$ 


\subsection{Texture analysis}

The curve showing load resulting from deformation of fruit was linear for all samples (Fig.1).At the start of experiment for control samples of Victoria fruits, work required for rupture of fruits was equal to $20.6 \pm 4.7 \mathrm{Nmm}$, and at the end of the experiment, it was equal to10.8 $\pm 4.8 \mathrm{Nmm}$. For the treated samples of Victoria this parameter changed from 25.1 \pm 9.8 to $17.8 \pm 4.5 \mathrm{Nmm}$. Camarosa fruits were more resistant against load force. Work to rupture untreated samples of Camarosa was equal $46.5 \pm 13.2 \mathrm{Nmm}$ at the start of experiment and reduced to $30.4 \pm 5.5 \mathrm{Nmm}$ after 13 days of storage. As to the treated samples of Camarosa, this parameter was $43.2 \pm 6.3 \mathrm{Nmm}$ on the first day of experiment, and $32.6 \pm 5.5 \mathrm{Nmm}$ on the 13-th day of storage. Thus, treatment with combined solution resulted in improvement of texture of fruits during storage process.

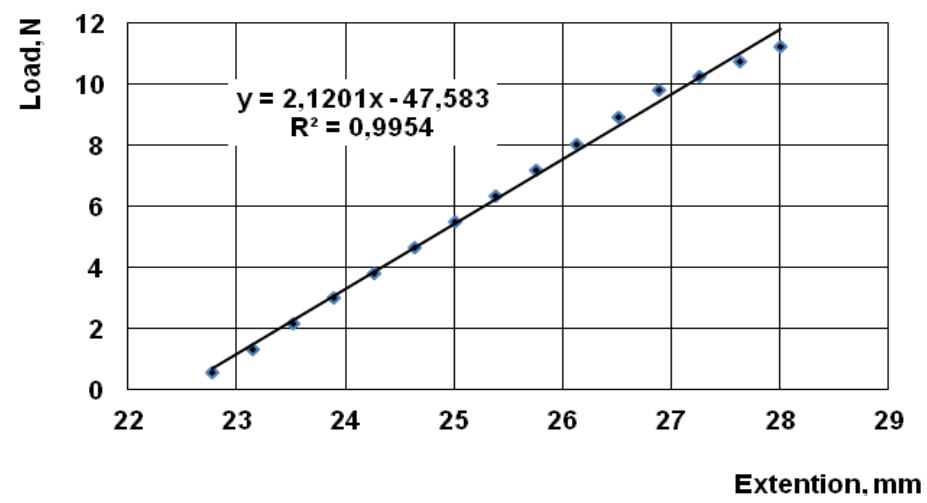

Figure 1. Load dependance on extention in camarosa fruits, control samples, first day

\section{Conclusions}

Treatment of fruits of strawberry with combined solutions of methyl jasmonate, salicylic acid and ascorbic acid positively influenced on storability of the fruits. Maintenance of anthocyanins and total phenolics as well as antioxidant potential during storage period was statistically significantly increased. Treatment with combined solution resulted in improvement of texture of fruits during storage process.

Acknowledgements. The authors declare no conflicts of interest. The research was carried out in the framework of the research task financed by Shota Rustaveli National Science Foundation (SRNSF), 216736.

\section{References}

1. Talcott S.T. (2007), Chapter 2. Chemical components of berry fruits. In: Yanyun Zhao (ed). Berry fruit, value-Added products for health promotion, CRC Press, pp. 51-73. 
2. Hakala M., Lapvetelainen A., Huopalahti R., Kallio H., Tahvonen R. (2003), Effects of varieties and cultivation conditions on the composition of strawberries, Journal of Food Composition and Analysis, 16, pp. 67-80.

3. Skrovankova S., Sumczynski D., Mlcek J., Jurikova T., Sochor J. (2015), Bioactive compounds and antioxidant activity in different types of berries. International Journal of Molecular Sciences, Basel, 16, pp. 24673-24706.

4. Slatnar A., Jakopic J., Stampar F., Vebric R., Jamnik P. (2012), The effect of bioactive compounds on in vitro and in vivo antioxidant activity of different berry juices, PLoS ONE, San Francisco, 7(10), pp. e47880-1-e47880-8.

5. Namiesnik J., Vearasilp K., Nemirovski A., Leontowicz H., leontowicz M., Pasko P., martinez0zyala A.L., Gonzalez-agular G.A., Suhaj M., Gorinstein S. (2014), In vitro studies on the relationship between the antioxidant activities of some berry extracts and their binding properties to serum albumin, Applied of Biochemistry and Biotechnology, 182, pp. 2849-2865.

6. Diaconeasa Z., Ranga F., Rugina F., Leopold L., Pop O., Vodnar D., Cuibus L., Socaciu C. (2015), Phenolic content and their antioxidant activity in various berries cultivated in Romania. Journal of Food Science and Technology, Oxford, 72(1), pp. 99-103.

7. Rice-Evans C.A., MillerN.J. (1996), Antioxidant activities of flavonoids as bioactive components of food. Biochemical Society Transactions, 24, pp. 790-795.

8. Heinonen I.M., MeyerA.S., FrankelE.N. (1998), Antioxidant activity of berry phenolics on human low-density lipoprotein and liposome oxidation, Jounal of Agricultural and Food Chemistry, 46, pp. 4107-4112.

9. Wills R.B.H. (1998), Enhancement of senescence in non-climacteric fruit and vegetables by low ethylene levels, Acta Horticulturae, 464, pp. 159-162.

10. De Antos B., Sanchez -Moreno C., De Pascual-Teresa S., Cano M.P. (2006), Freezing Principles, In: Y.H.Hui (ed.), Handbook of Fruit and Fruit Processig, Blackwell Publishing, pp. 59-80.

11. Raskin I. (1992), Role of salicylic acid in plants, Annual review of plant physiology and plant molecular biology, 43, pp. 439-463.

12. Turner J.G., Ellis C., Devoto A. (2002), The jasmonate signal pathway, Plant Cell, 14, pp. 153164.

13. Ueda, J. Saniewski, J. (2006), Methyl jasmonate-induced stimulation of chlorophyll formation in the basal part of tulip bulbs kept under natural light conditions, Journal of fruit and ornamental plant research, 14, pp. 199-210.

14. AliM.B., Hahn, E., Paek, K. (2007), Methyl jasmonate and salicylic acid induced oxidative stress and accumulation of phenolics in panax ginseng bioreactor root suspension cultures. Molecules, 12, pp. 607-621.

15. Cardemil TL., Nunes-Nesi A.,Retamales J., Jaakola L., Alberdi M., Ribera-Fonseca A. (2016), Methyl Jasmonate: An Alternative for Improving the Quality and Health Properties of Fresh Fruits, Molecules, 21, pp. 567, DOI:10.3390/moleculeas21060567

16. Zavala J.F.A., Wang S.Y., Wang C.Y., Aguilar G.A.G.(2004), Effects of Storage Temperatures on Antioxidant Capacity and Aroma Compounds in Strawberry Fruit, Elsevier Ltd. on behalf of Swiss Society of Food Science \& Technology.

17. Wang L., Li S. (2008), Role of Salicylic acid in postharvest Physiology, Fresh produce 2(1), pp.1-5.

18. Sapers G.M. (1993), Browning of foods: control by sulfites, antioxidants and other means, Food Technology, 47, pp.75-84.

19. Chiabrando V., Giacalone G. (2012), Effect of antibrowning agents on color and related enzymes in fresh-cut apples during cold storage, Journal of Food Processing and Preservation, 36, pp. 133-140.

20. Gomez P.L., Garcia-Loredo A., Nieto A., Salvadori A., Guerrero S., Alzamora S.M. (2012), Effect of pulsed light combined with an antibrowning pretreatment on quality fresh-cut apple, Innovative Food Science and Emerging Technology, 46, pp.102-112.

21. Remorini D., Landi M., Tardelli F., Lugani A., Massai R., Graziani G., Fogliano V., Guidi L. (2015), Effect of chlorine dioxide and ascorbic acid on enzymatic browning and fresh-cut red 
delicious and granny smith apples, Journal of Food Processing and Preservation, 39, pp. 29252934.

22. Alscher R.G., Donahue J.L., Cramer C.L. (1997), Reactive oxygen species and antioxidants: Relationship in green cells, Physiologia Plantarum, 100, pp. 224-233.

23. Osuga D., Van der Schaaf A. Whitaker J.R. (1994), Control of polyphenol oxidase activity using a catalytic mechanism. In: (R.Y. Yada, R.L. Jackman and J.L. Smith, (eds.) Protein StructureFunction Relationships in Foods, pp. NY, Springer, pp. 62-88.

24. Landi M., Deglinnocenti E., guglielminetti L., Guidi L. (2013), Role of ascorbic acid in polyphenol-oxidase inhibition and browning prevention in different browning-sensitive Lactuca sativa var. capitata (L.) and Eruca sativa (Mill.) stored as fresh-cut products, Journal of the science of food and agriculture, 93, pp. 1814-1819.

25. Koyunce M.A., Dilmagunal T. (2012), Determination of vitamin C and organic acid changes in strawberry by HPLC during cold storage, Notulae Botanicae Horti Agrobotanici, 38 (3), pp. 9598.

26. Rodrigues-Saona L.E., Wrolstad R.E. (2001), Extraction, isolation and purification of Anthocyanins. In: Wrolstad, R. E. (Ed.). Current protocols in food analytical chemistry. Hoboken: John Wiley \& Sons.

27. Prior R.L., Cao G., Martin A., Sofic E., Mcewen J., O’brien C., Lischner N., Ehlenfeldt M., Kalt W., Krewer G., Mainland C.M. (1998), Antioxidant capacity as influenced by total phenolic and anthocyanin content, maturity, and variety of vaccinium species, Journal of Agricultural and Food Chemistry, 46, pp. 2686-2693.

28. Tosun I., Ustun N.S., Tekguler B. (2008), Physical and chemical changes during ripening of blackberry fruits, Scientia Agricola, 65, pp. 87-90.

29. Giusti M.M., Wrolstad R.E. (2001), Characterization and measurement with UV visible spectroscopy. In: Wrolstad R. E. (Ed.), Current protocols in food analytical chemistry, John Wiley \& Sons.

30. Bond T.J., Lewis J.R., Davis A., Davis A.P. (2003), Analysis and Purification of Catechins and Their Transformation Products. In C. Santos-Bulga, G. Williamson (Eds.), Methods of polyphenols analysis, UK, The Royal Society of Chemistry, pp. $229-265$.

31. Benzie I.F.F., Strain J.J. (1996), The ferric reducing ability of plasma (FRAP) as a measure of "antioxidant power": the FRAP assay. Analytical Biochemistry, 239, pp.70 - 76.

32. Howard L.A., Wong A.D., Perry A.K., Klein B.P. (1999), Beta-carotene and ascorbic acid retention in fresh and processed vegetables, Journal of Food science, 64, pp. 929-936, DOI: 10.1111/j.1365-2621.1999.tb15943.

33. Lisiewska Z., Słupski J., Zuchowicz E. (2003), Effect of temperature and storage period on the preservation of vitamin $\mathrm{C}$, thiamine and riboflavin in frozen dill (Anethum graveolens L.), Electronic Journal of Polish Agricultural Universities, 6, pp. 1-7.

34. Phillips K.M., Tarragó-Trani M.T., Gebhardt S.E., Exler J., Patterson K.Y., Haytowitz D.B., Pehrsson P.R., Holden J.M. (2010), Stability of vitamin C in frozen raw fruit and vegetable homogenates, Journal of Food Composition and Analysis, 23, pp. 253-259, DOI:10.1016/j.jfca.2009.08.018.

35. Cätunescu G.M., Tofanä, M., Mureșan C., Ranga F., David A., Muntean M. (2012), The Effect of Cold Storage on Some Quality Characteristics of Minimally Processed Parsley (Petroselinum crispum), Dill (Anethum graveolens) and Lovage (Levisticum officinale), The Bulletin of University of Agricultural Sciences and Veterinary Medicin Cluj-Napoca, 6, pp. 213-221.

36. Cho K.S., Jeong H.J., Cho J.H., Park Y.E., Hong S.Y., Won H.S., Kim H.J. (2013), Vitamin C content of potato clones from Korean breeding lines and compositional changes during growth and after storage. Horticulture, Environment and Biotechnology, 54, pp. 70-75, DOI:10.1007/s13580-013-0089-8.

37. Huang X., Li J., Shang H., Meng X. (Effect of methyl jasmonate on the anthocyanin content and antioxidant activity of blueberries during, Journal of the science of food and agriculture, 95(2), pp. 337-343.

38. Kays S.J. (1991), Postharvest Physiology of Perishable Plant Products, An AVI Book, Van Nostrand Reinhold, New York. 
39. Turmanidze T., Gulua L., Jgenti M., Wicker L. (2017), Potential antioxidant retention and quality maintenance in raspberries and strawberries treated with calcium chloride and stored under refrigeration, Brazilian Journal of Food Technology Campinas, 20, e2016089.

40. Moyer R.A., Hummer K.E., Finn C.E., Frei B., Wrolstad R.E. (2002), Anthocyanins, Phenolics, and Antioxidant Capacity in Diverse Small Fruits: Vaccinium, Rubus, and Ribes, Journal of Agricultural and Food Chemistry, 50, pp. 519-525.

41. Burin V.M., Falcão L.D., Gonzaga L.V., Fett R., Rosier J.P., Marilde Terezinha Bordignon-Luiz M.T. (2010), Colour, phenolic content and antioxidant activity of grape juice, Food science and technology, 30(4), pp. 1027-1032,

42. Zhang J., Wang X., Yu O., Tang J., Gu X., Wan X., Fang C. (2011), Metabolic profiling of strawberry (Fragaria $\times$ ananassa Duch.) during fruit development and maturation, Journal of Experimental Botany, 62(3), pp. 1103-1118, DOI:10.1093/jxb/erq343 
Formation of the functional and technological properties of the beef minced meat by using the food additive on the nanopowder basis of double oxide of two- and trivalent iron

\author{
Iryna Tsykhanovska ${ }^{1}$, Lyudmyla Skurikhina ${ }^{2}$, \\ Victoria Evlash', Larisa Pavlotska²
}

1 - Ukrainian Engineering-Pedagogics Academy, Kharkiv, Ukraine

2 - Kharkiv State University of Food Technology and Trade, Kharkiv, Ukraine

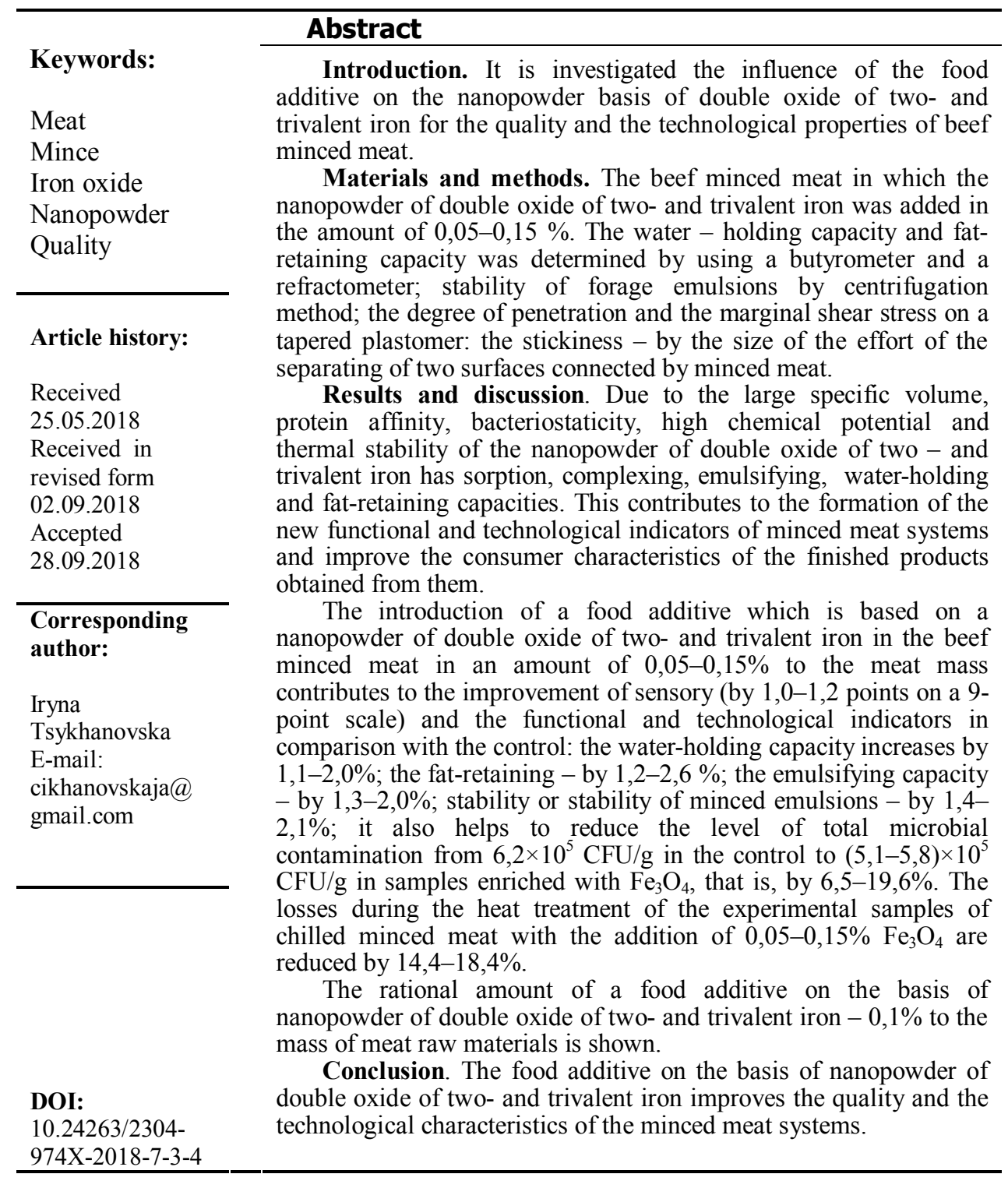




\section{Introduction}

At present time the increase in the meat quality with the low moisture in particular with PSE i DFD problems dictates the need to improve the existing technologies of meat products which permit the practical and effectively use of the meat formula with the indicated disadvantages. Therefore, the meat industry uses a variety of food additivesimprovers: biologically active additives (BAA), enriched with essential micro-elements and probiotic (BAA) $[1,2]$; protein formulation [3, 4]; water-retaining agents E450, E452 $[3,5]$; acidity regulators: E451, acetic acid, lactic acid, E262 [3, 6]; spices, spice extracts, dextrose, thickeners E412, E410, E415 [5, 6]; amplifiers of taste and aroma E621 [6]; antioxidants - citric, tartaric and ascorbic acid, E316 [6, 7]; natural food colors, in particular, red rice [6]; flavors, in particular, IN [5, 7]; colorants, in particular, $\mathrm{NaNO}_{3}$ [7].

One of the most common additives is glutamic acid E620 and its salts (E621, E622, etc.) without which almost any enterprise in the meat processing industry cann 't do today. These substances are able to enhance the products taste made from meat especially when using the low-grade stock causing a "sense of satisfaction". This property is called the "glutamine effect" [7]. However, food additives of this group do not bear any technological load which is why they are not necessary either [7].

Another group of food additives that are widely used in the meat industry there are the additives to improve the functional and technological indicators of the meat products, in particular, the increase in the water binding capacity (WBC) of the meat and meat products (sodium and potassium alginates [6,8]; agar, carrageenan [8, 9]; gums: carob, guar, xanthan, konduk $[6,8,10,11]$; insoluble dietary fibers of the different origin: wheat, soy, oat, pea, apple, citrus [12-14]; citrates [7, 15], food phosphates: pyro, tri- and polyphosphates [7, 8], cellulose, methylcellulose, to arboximethylcellulose [6-8, 13, 14]. However, they impair the quality and reduce the microbiological safety (as a result of high moisture content) and the economic performance of the product (due to the yield increasing and reducing of the finished products cost). Exceeding the recommended amount of phosphates $[7,8]$ and citrates $[7,13]$ leads to a loss of the products aroma taste and a pearl luster appears on the cut. The disadvantage of the insoluble dietary fibers [7, 13-14] is the instability of both high and low temperatures in the acidic media and the salts presence. The lack of insoluble dietary fiber [12-14] - lack of antioxidant and antimicrobial action. The need for accurate the alginates dosing $[6,8]$ makes it difficult to use them in the meat industry.

To improve the emulsifying capacity it is used the food emulsifiers based on fatty acids:fatty acids salts, mono- and diglycerides of fatty acids cetylated fatty acid [6, 7, 17]. However, they do not have an antioxidant effect.

In the meat processing plants for the improving of the nutrition value and the waterretention capacities it is used the various functional ingredients derived from the industrial by-products (skin, hooves, feathers, offal, etc.). They are used in the form of enriching powdered protein supplements [6, 19].

However these additives are characterized by a narrow focus and do not have a complex effect [19]. In the meat industry for improving of the nutrition value and quality of finished products it is used the natural phytosolids and probiotics [2, 20]. Their disadvantage is the functional properties loss during heat treatment. Nowadays to improve the quality and shelf life of the meat products the dietary supplements with antioxidant and antimicrobial effects of natural origin are used: essential oils, oils and fats [21, 22]. The disadvantages of these additives include the low water-retention capacity and the insufficient yield of finished products [21, 22]. 
Recently, silver, titanium dioxide and silicon dioxide nanopowders have been used as the polyfunctional food additives [23]. However the use of these additives in food products is very limited, since their functional, technological, microbiological, and physicalchemical parameters have not been studied sufficiently [23]

Thus, the well-known food additives-improvers, as a rule, separately allow to improve the certain functional and technological characteristics, the product quality; slow down the processes of oxidative, microbial damage; lengthen storage time. However, they do not have a complex action.

Therefore, it is relevant in the meat-processing industry to search for and research the food polyplastic additives of the complex action.

For the formation of the necessary functional and technological properties of the meat products can be offered a dietary supplement based on iron oxides "Magnetofood" [Patent UA No. 126502 Food additive "Magnetofood", 2018, Bul. No. 12, 4 p., Ukrainian Engineering Pedagogical Academy, Kharkov, Ukraine], which is a scientific development of the authors of this research paper. "Magnetofood" is a highly dispersed nanopowder with a particle size of $70-80 \mathrm{~nm}$ and with a large specific surface and chemical potential [2428]. According to the chemical formulation "Magnetofood" is a double iron oxide ( $\mathrm{FeO}$. $\mathrm{Fe}_{2} \mathrm{O}_{3}$ aбo $\mathrm{Fe}_{3} \mathrm{O}_{4}$ ) which was obtained by the using the improved technology that allows to obtain nanoparticles of a given size; adjustment the physical-chemical and functionaltechnological properties; reduce the process complexity and the cost of the final product [24, 29 -31]. Due to Fe (II), "Magnetofood" shows the reducing properties and can be used as an antioxidant additive which prevents the fats oxidation and fat-containing products and thereby improves their quality and the period of use [32, 33]. Considered the biological compatibility of the supplement "Magnetofood" with the living organisms and its positive effect on the human body $[24,34]$ it is possible to use the food additive based on $\mathrm{Fe}_{3} \mathrm{O}_{4}$ nanopowder ("Magnetofood") as an additional source of the easily digestible iron [24, 35].

Nanoobjects which include a nanopowder based on $\mathrm{Fe}_{3} \mathrm{O}_{4}$ iron oxides ("Magnetofood") have a huge potential and carry a lot of the important fundamental discoveries, the new functional-technological properties and promising technological applications [36, 37].

The nanoparticles interaction of a food additive based on $\mathrm{Fe}_{3} \mathrm{O}_{4}$ nanopowder ("Magnetofood") with biopolymers (proteins, proteins, carbohydrates, lipids) it is a complex of the complex chemical reactions. The process of nucleation is nucleation of a new stable phase with an initial metastable phase passes through. The supramolecular organization of "Magnetofood" nanoparticles and the organic matrix structure play an important role. The result is the formation of spatial nanostructures that significantly affect on the functional and technological properties of raw materials and semi-finished products. In food systems such additives in particular, a food additive, based on $\mathrm{Fe}_{3} \mathrm{O}_{4}$ nanopowder ("Magnetofood") can show restorative, antioxidant, bacteriostatic, sorption, complexing, emulsifying, water-binding, water-retaining, greasy properties [24, 38-42].

The researchers of VM Pasechny, TA Shugurova, NN Tolkunova and others have devoted their research to the modern directions of the technologies perfection for the meat split-off semifinished products. In numerous scientific publications the innovative approach prospects to the development or the technology improvement of the meat-split semifinished products are considered both in the aspect of the formation of the formulation with the use of additive- improvers and the technological process improvement [43-47].

Hence, the advanced way of the issue solution of the improving technological, sensory qualities and ensuring their stability and safety, extending the meat products shelf life, in particular, split semis can be used the new food ingredients which designed to perform, as a rule, the several functions at the same time: the structure formers, stabilizers, emulsifiers, 


\section{- Food Technology -}

antioxidants; to possess bacteriostatic, water-retention and fat-containing capacities [4547].

Therefore, the research related to the technology improvement of the high-quality meat products with a long shelf life with the food additives of complex action is relevant and well-timed.

Also the unknown effect of the food additive based on $\mathrm{Fe}_{3} \mathrm{O}_{4}$ nanopowder ("Magnetofood") on the sensory characteristics, the structural and mechanical and functional-technological properties of the meat-split semi-finished products, in particular, the beef mincemeat in the beef steaks technology.

As this research is the integral part of the authors' scientific and practical work for the beef steaks technology improving of a food additive using based on $\mathrm{Fe}_{3} \mathrm{O}_{4}$ nanopowder ("Magnetofood"), the aim of this work is to research the functional and technological properties of the beef minces by using of the food additives of $\mathrm{Fe}_{3} \mathrm{O}_{4}$ nanopowder ("Magnetofood") and determine the rational mass fraction of its addition.

To achieve the aim the following tasks were set:

- to investigate the effect of "Magnetofood" food additive on the heat treatment losses and sensory characteristics of prototypes of chilled beef mince after storage for 24 hours at $5{ }^{\circ} \mathrm{C} \pm 1{ }^{\circ} \mathrm{C}$;

- to investigate the influence of "Magnetofood" food additive on the functional and technological properties of prototypes of fresh made and chilled beef mince after storage for 24 hours at $5{ }^{\circ} \mathrm{C} \pm 1{ }^{\circ} \mathrm{C}$;

- to investigate the influence of "Magnetofood" food additive on the microbiological indicators of the test samples of fresh made and chilled beef mince after storage for 24 hours at $5{ }^{\circ} \mathrm{C} \pm 1{ }^{\circ} \mathrm{C}$;

- to investigate the influence of "Magnetofood" food additive on the structural and mechanical properties of the experimental samples of fresh made beef mince;

- to establish a rational mass fraction of "Magnetofood" food additive in the experimental samples of the beef mince.

\section{Materials and methods}

\section{Materials}

Object of research: the effect of the food additive based on $\mathrm{Fe}_{3} \mathrm{O}_{4}$ nanopowder ("Magnetofood") on the heat treatment losses; the functional and technological (emulsifying, water-binding, water-retention and fat-containing capacities, the stability of beef mince emulsion) and the structural-mechanical (ultimate shear stress, stickiness), and the properties; the sensory and microbiological (the level of total microbial contamination NMAFAnM, the number of bacteria of the coliform bacterium group - BCBG, bacteria of the genus Salmonella and L. Monocytogenes) the indicators of beef minced meat.

Research subjects:

- sample 1 control is beef mince. For its preparation the meat was taken: prime beef or the first quality. After cleansing and degreasing, the beef was ground on a meat grinder with a diameter of the openings of the output grating of $3-4 \mathrm{~mm}$. Then the sample was thoroughly mixed with salt and spices and held for 10 minutes;

- sample 2 is beef mince which was prepared as in sample 1. Only a mixture of the spices, salt and nutrient additive based on $\mathrm{Fe}_{3} \mathrm{O}_{4}$ nanopowders ("Magnetofood") was 
added to the crushed beef (the amount of the additive was $0,05 \%$ relative to the meat raw mass). Then the sample was thoroughly mixed and held for 10 minutes;

- sample 3 is beef mince which was prepared like sample 1. Only a mixture of spices, salt and food additive based on $\mathrm{Fe}_{3} \mathrm{O}_{4}$ nanopowder ("Magnetofood") was added to the crushed beef (the amount of additive was $0,10 \%$ relative to the meat raw mass). Then the sample was thoroughly mixed and kept for 10 minutes.

- sample 4 is beef mince which was prepared like sample 1. Only a mixture of spices, salt and food additive based on $\mathrm{Fe}_{3} \mathrm{O}_{4}$ nanopowder ("Magnetofood") was added to the crushed beef (the amount of additive was $0,15 \%$ relative to the meat raw mass). Then the sample was thoroughly mixed and kept for 10 minutes.

All samples were stored in a vacuum package at a temperature of $(5 \pm 1)^{\circ} \mathrm{C}$ for 24 hours, the heat losses were investigated; their emulsifying, water-binding, water-retention and fat-containing capacities; emulsion stability; the rheological characteristics (shear stress, stickiness) are the microbiological (the level of total microbial contamination is NMAFAnM, the number of bacteria of the coliform bacterium group - BCBG, bacteria of the genus Salmonella and L. Monocytogenes) and the sensoryal indicators (appearance, sectional view, consistency, odor and taste).

Food additive based on iron oxides ("Magnetofood") [Patent UA No. 126502 Food additive "Magnetofood", 2018, Bul. No. 12, 4 p., Ukrainian Engineering Pedagogical Academy, Kharkov, Ukraine], which is a scientific development of the authors of this research paper. "Magnetofood" is a highly dispersed nanopowder of brown or black color with a particle size $78 \mathrm{~nm}$. According to the chemical composition of "Magnetofood" is a double ferrous oxide $\left(\mathrm{FeO} \cdot \mathrm{Fe}_{2} \mathrm{O}_{3}\right.$ or $\left.\mathrm{Fe}_{3} \mathrm{O}_{4}\right)$ obtained by the method of the chemical coprecipitation from aqueous solutions of salts of two- and trivalent ferrum in the alkaline medium.

\section{Methods}

In the researches the mince recipe for beef steak was chosen as the basic formula [48].

In the process of performing experimental work the research methods were used which are given in [40, 49, 51].

The heat treatment of the experimental samples of the minced meat was carried out by the frying method in the main way at a frying surface temperature of $150-160^{\circ} \mathrm{C}$ till the temperature of culinary readiness in the center of the product is reached $(85 \pm 1)^{\circ} \mathrm{C}$.

\section{Losses determination during the heat treatment and sensory parameters of the experimental samples of beef mince}

In the inal meat solid products it was researched the finished product yield (FPY) and heat treatment losses (HTL) which was determined as the difference in the case of the initial semi-finished product and the finished product in accordance with the methods [49, 51].

Sensory estimation of the minced meat quality and products made from them was carried out on a 9-point scale in accordance with $[40,49,50]$. To estimate of the minced meat quality from beef and made of meat split products according to sensory indicators, the study samples were taken from the different places of the stuffing mass depending on the volume and from 3 to 7 . The appearance of minced meat semi-finished products was determined visually raw and fried. The quality of beef (grinding degree, equability mixing, texture) was determined visually. The smell and taste of minced meat and split meat semi- 
finished products, as well as fried products made from them, were determined organoleptically at the cut. Moreover, the appearance and smell of the fried products was determined sensory in the hot condition (the product temperature is not lower than $65^{\circ} \mathrm{C}$ ) and the taste after cooling the product to a temperature of $25-30{ }^{\circ} \mathrm{C}$.

The degree of grinding and equability mixing of the minced meat and also the correctness of split products heat treatment made from them were determined visually in the hot products (the product temperature is not lower than $65^{\circ} \mathrm{C}$ ), for which each product was cut into four parts (along and across through the middle).

\section{Determination of functional and technological properties of the beef mince prototypes}

The water-holding capacity (WHC) was determined by using a butyrometer according to the method [49]. The sample of minced meat portion weighing 4-5 g was thoroughly crushed. The glass rod was uniformly applied to the inner surface of the milk butyrometer which was punched with a stopper and placed narrowly into the water bath at a boiling temperature for $15 \mathrm{~min}$. After that the moisture mass was determined according to the amount of division on the scale of the butyrometer. Water-holding capacity (WHC) of the minced meat (\%) was determined by the formula (1):

$$
\mathrm{WHC}=\mathrm{W}-\mathrm{WHLC}
$$

water-highlighting capacity (WHIC) of the minced meat (\%) (2):

$$
\mathrm{WHIC}=\mathrm{a} \cdot \mathrm{m} \cdot \mathrm{n}^{-1} \cdot 100,
$$

$\mathrm{W}-$ is the total mass fraction of moisture in the weight, $\%$;

$\mathrm{a}-$ is the price of dividing the butyrometer; $\mathrm{a}=0,01 \mathrm{~cm}^{-1}$;

$\mathrm{n}-$ is the number of divisions on the zymometer scale;

$\mathrm{m}-$ is the sample weight, $\mathrm{g}$

Fat-retaining capacity (FRC) was determined by using a butyrometer and refractometer according to the method [49]. The MPC was preliminarily calculated and the minced meat weight was found that remained in the oil with an accuracy of

$\pm 0,0001 \mathrm{~g}$. The sample was placed in a tube and dried to a post mass at $150{ }^{\circ} \mathrm{C}$ for 1,5 hours. After drying, the sample weighing $(2,0000 \pm 0,0002) \mathrm{g}$ is placed in a porcelain mortar, 2,5 $\mathrm{g}\left(1,6 \mathrm{~cm}^{3}\right)$ of fine calcined sand and $6 \mathrm{~g}\left(4,3 \mathrm{~cm}^{3}\right) \alpha$ - monobromo-naphthalene are added. The contents of the mortar were carefully ground for 4 minutes and filtered through the folded paper filter.

The investigated solution (3-4 drops) was evenly applied to the lower prism of the refractometer with a glass rod. The prism was closed by fastening the screw. The beam of light was directed with the help of a mirror on the prism of the refractometer, setting the sight tube so that the borders of the intersecting fields (aliada) were clearly visible. Aliada moved until the boundary between the illuminated and the dark fields did not coincide with the intersection point of their limits, counting the index of refraction. At the same time the refractive index of $\alpha$-monobromonaphthalene was determined. Fat-retaining capacity of forcemeat (FRC) (\%) was determined by the formula (3):

$$
\mathrm{FRC}=\mathrm{g}_{1} \cdot \mathrm{g}_{2}{ }^{-1} \cdot 100
$$

where $\mathrm{g}_{1}-$ is the fat mass fraction in the weight after the heat treatment, \%;

$\mathrm{g}_{2}-$ is the same one before the heat treatment, $\%$.

The emulsifying capacity (EC) and the stability or the emulsion stability (ES) were determined according to the procedure $[49,50]$. A portion of ground beef by the weighing 
$7 \mathrm{~g}$ is suspended in $100 \mathrm{~cm}^{3}$ of the water in a homogenizer at a frequency of $66,6 \mathrm{~s}^{-1}$ for 60 s. $100 \mathrm{~cm}^{3}$ of the sunflower oil are added and the mixture is emulsified in a homogenizer at a speed of $1500 \mathrm{~s}^{-1}$ for 5 minutes. Then the emulsion is poured into 4 calibrated centrifugal tubes with a volume of $50 \mathrm{~cm}^{3}$ and centrifuged at $500 \mathrm{~s}^{-1}$ for 10 minutes. It is determined the volume of the emulsified oil. The emulsifying ability (EC) (\%) was determined by the formula (4):

$E C=V_{1} / V \cdot 100$
where $V_{1}-$ is the volume of the emulsified oil, $\mathrm{cm}^{3}$

$\mathrm{V}-$ is the total volume of oil, $\mathrm{cm}^{3}$.

The emulsion stability (ES) was determined by the heating at a temperature of $80{ }^{\circ} \mathrm{C}$ for 30 minutes. and the cooling water for 15 minutes. Then emulsion was filled with 4 calibrated centrifuged tubes in a volume of $50 \mathrm{~cm}^{3}$ and centrifuged for $500 \mathrm{~s}^{-1}$ for 5 minutes. It is determined the volume of the emulsified layer. The emulsion stability (ES) (\%) was determined by the formula (5):

$E S=V_{1} / V_{2} \cdot 100$
where $V_{2}-$ is the total volume of the emulsion, $\mathrm{cm}^{3}$

R.M. Salavatulina determined the WHC, FRC and the stability of the stuffing emulsions (SE) in one weight $[49,51]$.

The minced meat samples by the weighing 180-200 g, were placed in the hermetically sealed cans № 3, weighed and subjected to the heat treatment with the modes corresponding to the production (cooking at temperatures of $78-80{ }^{\circ} \mathrm{C}$ for 1 hour, cooled in the running water to a temperature of $12-15{ }^{\circ} \mathrm{C}$ ).

The cans were opened the broth and the fat released were transferred into pre-weighted cans. After removing the broth and fat, minced meat was blotted with filter paper and weighed. Buks with broth were placed in a drying cabinet and dried to constant weight at a temperature of $103-105{ }^{\circ} \mathrm{C}$. The mass fraction of moisture released during the heat treatment of minced meat and the water-holding capacity of minced meat were determined. From the cups with the rest of the broth and fat, the fat was extracted in $10-15 \mathrm{~cm}^{3}$ of solvents, (a mixture of chloroform and ethanol in a 1: 2 ratio). The fat extraction was carried out for 3 to 4 minutes from three to four replicates. Having established the mass fraction of the fat remaining after the heat treatment of minced meat it was calculated the grease capacity. The stability of the stuffing emulsion ( $\%$ by weight of meat) was determined by the formula (6).

where $\mathrm{m}=\mathrm{m}_{\mathrm{tk}}-\mathrm{m}_{\mathrm{t}}$;

$$
\mathrm{SE}=\left(\mathrm{m}-\mathrm{m}_{\mathrm{b} 1} / \mathrm{m}\right) \cdot 100, \text { or } \mathrm{SE}=\mathrm{m}_{\mathrm{b}} / \mathrm{m} \cdot 100,
$$

$\mathrm{m}_{\mathrm{bl}}=\mathrm{m}-\mathrm{m}_{\mathrm{b}}$

$\mathrm{m}$ - mass of minced meat, $\mathrm{g}$;

$\mathrm{m}_{\mathrm{b} 1}-$ mass of broth with highlighted fats, $\mathrm{g}$;

$\mathrm{m}_{\mathrm{b}}$ - mass of the bunch of the minced meat after the heat treatment, $g$;

$\mathrm{m}_{\mathrm{tk}}-$ mass of tight cans with fork stuffed, $\mathrm{g}$;

$\mathrm{m}_{\mathrm{t}}-$ the weight of cans, $\mathrm{g}$

WHC of the minced meat ( $\%$ to the weight of minced meat) was determined by the formula (7):

$$
\mathrm{WHC}=\left(\left(\mathrm{W}-\mathrm{m}_{\mathrm{b} 1} \cdot \mathrm{m}_{\mathrm{b}}\right) / \mathrm{m}_{\mathrm{b} 2} \cdot \mathrm{m}\right) \cdot 100,
$$

where $\mathrm{W}$ - the mass fraction of moisture in the minced meat, $\%$;

$\mathrm{m}_{\mathrm{b}}$ - the mass in the investigated broth, $\mathrm{g}$;

$\mathrm{m}_{\mathrm{b} 2}-$ the mass of the broth investigated with fat, $\mathrm{g}$. 
FRC of the minced meat ( $\%$ to the weight of minced meat) was determined by the formula (8):

$$
\mathrm{FRC}=\mathrm{F}_{\mathrm{f}}-\mathrm{m}_{\tilde{\sigma} 1} \cdot \mathrm{m}_{\mathrm{fb}} / \mathrm{m}_{\mathrm{6} 2} \cdot \mathrm{m},
$$

where $\mathrm{F}_{\mathrm{f}}$ - the fat mass fraction in the minced meat, \%;

$\mathrm{m}_{\mathrm{fb}}$ - the fat body mass in the investigated broth, $\mathrm{g}$.

\section{Determination of microbiological parameters and structural and mechanical properties of test samples of beef minced meat}

The list of the microbiological indicators used to control the quality of minced meat was established following the requirements: the number of mesophilic aerobic and facultative anaerobic microorganisms (NMAFAnM, KUO/g); the presence of bacteria in the group of coliform bacterium (BGCB (coliform), in $0,001 \mathrm{~g}$ ); detection of the golden staphylococci, protein and other pathogenic microorganisms (pathogenic microorganisms including bacteria of the genus Salmonella, in $25 \mathrm{~g}$ ) [40, 44, 45].

With the structural-mechanical (rheological) properties of the minced meat the degree of penetration $(h)$ and ultimate shear stress $\left(\theta_{0}\right)$ on a conical plastomer were determined using a conical identifier [49].

The experimental sample of the beef minced cooking is made of the appropriate consistency and placed in the device cuvette. Align the surface of the experimental sample with the metal ruler so that the minced meat in the cuvette is level with its edges. A cuvette with a prototype set on the table of the instrument and raised up to the touch of the surface with the edge of the cone. Press the start button, turn on the stopwatch and holding the bar at a slight pace lower the cone. As the immersion cone like minced meat fixes the depth of immersion of the corrugated cone through the indicator every minute. Dipping ends in 3-5 minutes as at the end of this time the cone drops to a slight depth which can be practically neglected. The immersion drainage from 180 to $300 \mathrm{~s}$ corresponds to the largest period of relaxation of meaty minced meat from the beef used for research.

Fix the magnitude of the angle $2 \alpha$ at the vertex of the cone and the cone constant $\mathrm{C}$ $(\mathrm{m} / \mathrm{kg})$, the total mass of $\mathrm{m}_{\text {tot }}(\mathrm{kg})$ of the rod, the mass of the cone $\left(\mathrm{m}_{\mathrm{ind}}\right)$ and the mass of the additional load $\left(\mathrm{m}_{\mathrm{ad}}\right)$ by its presence. It is known that the depth of the immersion of a conical ident $\left(\mathrm{h}_{\text {ind }}\right)$ is equal to the degree of penetration $(\mathrm{h})$ and is a function of the total mass, that is, according to the formula (9):

$$
\mathrm{h}=\mathrm{h}_{\text {ind }}=\mathrm{f}\left(\mathrm{m}_{\mathrm{tot}}\right) \text {, }
$$

where $\mathrm{h}_{\text {ind }}-$ depth of immersion of a conical ident, $\mathrm{mm}$;

$\mathrm{h}$ - degree of penetration of the prototype, $\mathrm{mm}$;

$\mathrm{m}_{\mathrm{tot}}$ - total weight of the bar of the cone plastomer, $\mathrm{kg}$

Hence, the estimated value of the mass of goods was determined by the formula (10):

$$
\mathrm{m}_{\mathrm{tot}}=\mathrm{m}_{\mathrm{ad}}+\mathrm{m}_{\text {ind }}
$$

where $\mathrm{m}_{\mathrm{tot}}$ - is the total weight of the bar of the tapered plastomer, $\mathrm{kg}$;

$\mathrm{m}_{\mathrm{ad}}$ - is the mass of additional load, $\mathrm{kg}$

$\mathrm{m}_{\text {ind }}-$ mass of cone identor, $\mathrm{kg}$.

For each sample, the boundary shear stress $\theta(\mathrm{Pa})$ was calculated for a fixed immersion duration (h) by the formula (11):

$$
\theta=\mathrm{K} \cdot \mathrm{m} / \mathrm{h}_{2}=\mathrm{K} \cdot \mathrm{m}_{\text {tot }}-\mathrm{m}_{\text {ind. } /} \mathrm{h}^{2},
$$

where $\mathrm{m}_{\mathrm{tot}}-$ is the total weight of the bar of the tapered plastomer, $\mathrm{kg}$;

$\mathrm{m}$ - the weight of the experimental sample, $\mathrm{kg}$;

$\mathrm{m}_{\text {ind }}-$ the mass of conical identer, $\mathrm{kg}$; 
$\mathrm{C}$ - the constants of the cone of the ident;

$\mathrm{h}$ - the depth of immersion of a conical ident, $\mathrm{mm}$.

The arithmetic mean of the marginal shear stress $(\theta)$ for each of the variants $(\theta i)$ of the experimental sample (i) was determined by the formula (12):

$$
\theta=\Sigma \theta_{\mathrm{i}} / \mathrm{i},
$$

where $\theta$ - is the arithmetic mean value of the marginal strain of displacement, Pa;

$\theta_{i}-$ is the strain of the displacement of the experimental sample of minced beef, $\mathrm{Pa}$

$\mathrm{i}$ - the number of samples of the beef minced samples.

The liposynthesis $\left(\rho_{0}\right)$ was investigated on Sokolov-Bolshakov device which was based on the determination effort amount required to separate the two surfaces of the bound (bonded) minced meat that is being investigated. Adhesion or adhesion ( $\mathrm{Pa}$ ) was calculated as the specific force of the normal separation of the plate from the prototype minced meat from the beef by the formula (13):

where $\mathrm{F}_{\mathrm{o}}-$ is the separation force, $\mathrm{N}$;

$$
\rho_{\mathrm{o}}=\mathrm{F}_{\mathrm{o}} / \mathrm{S}_{\mathrm{o}}=9,81 \cdot \mathrm{m} / \mathrm{F}_{\mathrm{o}}
$$

$\mathrm{S}_{\mathrm{o}}$ - the geometric area of the plate, $\mathrm{m}^{2}$;

$\mathrm{m}-$ the weight of the load, $\mathrm{kg}$.

\section{Results and discussion}

Table 1 and Figure 1 show the of the heat treatment losses and sensory evaluation data of the cooled experimental samples of the beef minced meat.

Table 1

The losses results due to the heat treatment and the sensory parameters of the experimental samples of the cooled minced beef (on a 9 - point scale)

\begin{tabular}{|l|c|c|c|c|}
\hline \multirow{2}{*}{\multicolumn{1}{|c|}{ Name of the indicator }} & \multicolumn{4}{|c|}{ The experimental samples of the minced beef } \\
\cline { 2 - 5 } & Sample 1 & Sample 2 & Sample 3 & Sample 4 \\
\hline The heat treatment losses \% & 20,6 & 18,0 & 17,5 & 17,4 \\
\hline Appearance & $8,0 \pm 0,2$ & $9,0 \pm 0,2$ & $9,0 \pm 0,2$ & $9,0 \pm 0,2$ \\
\hline Appearance in the sections & $8,0 \pm 0,2$ & $9,0 \pm 0,2$ & $9,0 \pm 0,2$ & $8,0 \pm 0,2$ \\
\hline Consistence & $7,0 \pm 0,2$ & $8,0 \pm 0,2$ & $9,0 \pm 0,2$ & $9,0 \pm 0,2$ \\
\hline Scent and taste & $8,0 \pm 0,2$ & $9,0 \pm 0,2$ & $9,0 \pm 0,2$ & $9,0 \pm 0,2$ \\
\hline \multicolumn{1}{|c|}{ Averaged scoring value } & $7,8 \pm 0,2$ & $8,8 \pm 0,2$ & $9,0 \pm 0,2$ & $8,8 \pm 0,2$ \\
\hline
\end{tabular}

The analysis of the experimental data in the Table 1 shows that when introducing a food additive based on $\mathrm{Fe}_{3} \mathrm{O}_{4}$ nanopowders ("Magnetofood") in the experimental samples of the cooled minced beef the losses amount in their heat treatment is reduced with the increase in $\mathrm{Fe}_{3} \mathrm{O}_{4}$ content by $14,4-18,4 \%$.

The data given in Table 1 and Figure 1 indicate a positive effect of the adding $\mathrm{Fe}_{3} \mathrm{O}_{4}$ nanopowders to meat stuffing systems. The sensory parameters of the experimental samples of the cooled minced beef enriched with a food additive based on $\mathrm{Fe}_{3} \mathrm{O}_{4}$ nanopowder ("Magnetofood") are improved. The average scoring value for the sensory parameters increases by 1,0-1,2 points in comparison with the control. 


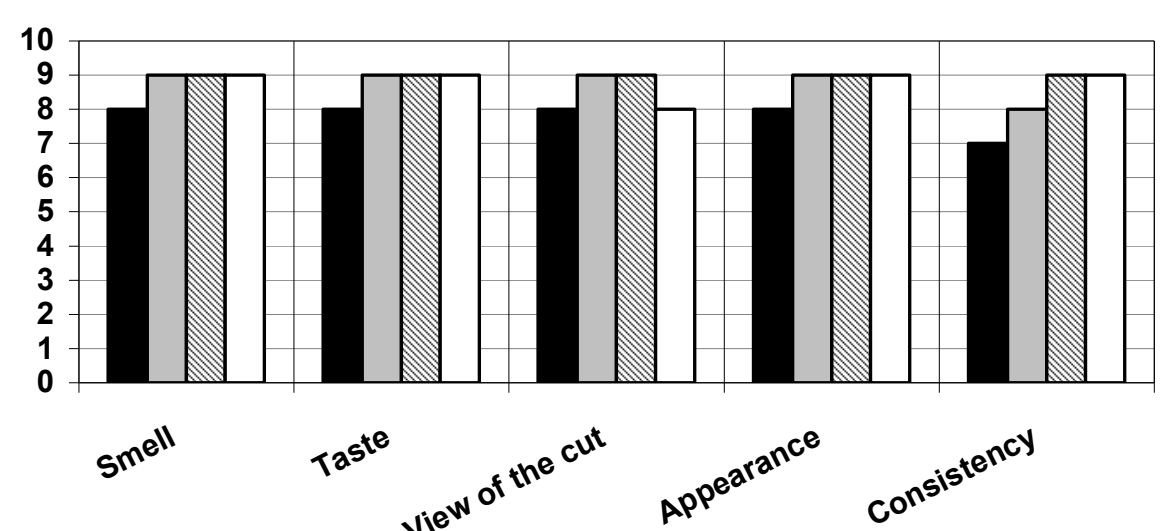

Sample 1

$\square$ Sample 2

Sample 3

$\square$ Sample 4

Figure 1. Sensory indicatory quality of the experimental samples of cooled minced beef

The introduction of a nutritional supplement based on $\mathrm{Fe}_{3} \mathrm{O}_{4}$ nanopowder ("Magnetofood") and its ability to the electrostatic and coordination interaction with proteins of meat forages systems leads to the changes in the moisture content of the experimental samples and the water-retaining capacity of minced meat and consequently changes in the heat treatment losses whose the value decreases with increasing $\mathrm{Fe}_{3} \mathrm{O}_{4}$ content [29]. The optimum mass fraction of $\mathrm{Fe}_{3} \mathrm{O}_{4}$ additives which provides the best sensory characteristics of meat sausages and less heat treatment losses is $0,10 \%$.

The water-holding (WHC) and fat-retaining (FRC) capacity causes the product properties to store in it the prescribed amount of moisture and fat in the cooking process. Therefore, these characteristics are the main functional and technological properties of the meat forages systems. In the heat treatment process of the meat cut trunks and the physical and chemical changes of the ingredient composition occur. The part of moisture and fat are separated in the form of bouillon-fatty flushes which shows the result in the mass loss. As part of the finished product the moisture and fat retained and the amount determines the moisture and fat-retaining capacity of minced meat [28].

Table 2 presents the main functional and technological properties of the experimental samples of beef minced meat: WHC and FRC and the emulsifying capacity (EC), emulsion stability (ES) when adding the additive based on $\mathrm{Fe}_{3} \mathrm{O}_{4}$ nanopowder ("Magnetofood") compared to control.

In the experimental samples of freshly prepared beef minced there is a gradual increase in WHC, FRC, EC, ES with an increase in $\mathrm{Fe}_{3} \mathrm{O}_{4}$ mass fraction in comparison with the control sample: WHC is increased by $1,1-2,0 \%$; FRC by $1,2-2,6 \%$; EC by $1,3-2,0 \%$; ES by $1,4-2,1 \%$.

The similar dynamics changes in these indices and in the experimental samples of cooled minced meat in 24 hours of their storage at $6{ }^{\circ} \mathrm{C} \pm 1{ }^{\circ} \mathrm{C}$ only in all cases their value is lower by $1,3 \%-2,0 \%$ compared to freshly prepared beef minced meat. The best result is obtained with $\mathrm{Fe}_{3} \mathrm{O}_{4}$ mass fraction of $0,10 \%$. Further increase of $\mathrm{Fe}_{3} \mathrm{O}_{4}$ to $0,15 \%$ practically does not affect the indicators change. 
Table 2

Functional and technological properties of freshly prepared and the cooled beef minced meat after storage with the addition of a nutritional additive based on $\mathrm{Fe}_{3} \mathrm{O}_{4}$ nanopowder

("Magnetofood") in comparison with the control sample

\begin{tabular}{|c|c|c|c|c|c|}
\hline \multicolumn{2}{|c|}{ Name of the indicators } & \multicolumn{4}{c|}{ The experimental samples } \\
\cline { 2 - 6 } \multirow{2}{*}{$\begin{array}{c}\text { WHC } \\
\%\end{array}$} & $\begin{array}{c}\text { freshly prepared beef } \\
\text { minced meat }\end{array}$ & $76,3 \pm 0,9$ & $77,2 \pm 0,9$ & $77,6 \pm 0,9$ & $77,7 \pm 0,9$ \\
\cline { 2 - 6 } & $\begin{array}{c}\text { in } 24 \text { hours of the } \\
\text { storage at } 6 \pm 1{ }^{\circ} \mathrm{C}\end{array}$ & $75,3 \pm 0,9$ & $76,7 \pm 0,9$ & $77,1 \pm 0,9$ & $77,2 \pm 0,9$ \\
\hline \multirow{2}{*}{ FRC,\% } & $\begin{array}{c}\text { freshly prepared beef } \\
\text { minced meat }\end{array}$ & $72,1 \pm 0,7$ & $73,3 \pm 0,8$ & $73,8 \pm 0,9$ & $73,9 \pm 0,8$ \\
\cline { 2 - 6 } & $\begin{array}{c}\text { in } 24 \text { hours of the } \\
\text { storage at } 6 \pm 1{ }^{\circ} \mathrm{C}\end{array}$ & $71,6 \pm 0,7$ & $72,7 \pm 0,8$ & $72,9 \pm 0,9$ & $73,0 \pm 0,8$ \\
\hline \multirow{2}{*}{ EC,\% } & $\begin{array}{c}\text { freshly prepared beef } \\
\text { minced meat }\end{array}$ & $78,2 \pm 0,9$ & $79,2 \pm 0,9$ & $79,5 \pm 0,9$ & $79,8 \pm 0,9$ \\
\cline { 2 - 6 } & $\begin{array}{c}\text { in } 24 \text { hours of the } \\
\text { storage at } 6 \pm 1{ }^{\circ} \mathrm{C}\end{array}$ & $77,2 \pm 0,9$ & $77,9 \pm 0,9$ & $78,3 \pm 0,9$ & $78,4 \pm 0,9$ \\
\hline \multirow{2}{*}{ ES, \% } & $\begin{array}{c}\text { freshly prepared beef } \\
\text { minced meat }\end{array}$ & $80,2 \pm 0,8$ & $81,3 \pm 0,8$ & $81,6 \pm 0,9$ & $81,7 \pm 0,8$ \\
\cline { 2 - 6 } & $\begin{array}{c}\text { in } 24 \text { hours of the } \\
\text { storage at } 6 \pm 1{ }^{\circ} \mathrm{C}\end{array}$ & $79,2 \pm 0,8$ & $79,9 \pm 0,8$ & $80,2 \pm 0,9$ & $80,3 \pm 0,8$ \\
\hline
\end{tabular}

The surface-active, sorption, complexing properties of the ionized nanoparticles of a food additive based on $\mathrm{Fe}_{3} \mathrm{O}_{4}$ nanopowder ("Magnetofood"), its catalytic activity, heat treatment stability, bio-affinity of the main component of "Magnetofood" - $\mathrm{Fe}_{3} \mathrm{O}_{4}$ nanoparticles with a lot of proteins determine the emulsifying, wetting, wet and fatretaining capacity of "Magnetofood" [39]. Therefore, the introduction of the additive "Magnetofood" to meat minced meat increases the level of moisture and fat content and the formation of stable emulsions, in particular, with the lipid and protein components of meat sausage systems.

On the sanitary well-being of meat minced meat enriched with a food additive based on $\mathrm{Fe}_{3} \mathrm{O}_{4}$ nanopowder ("Magnetofood") were judged by the microbiological parameters in accordance with $[40,44,45]$. The microbiological characteristics of freshly prepared $(*)$ and cooled beef minced meat $(* *)$ were researched after storage at a temperature of $-5{ }^{\circ} \mathrm{C}$ $\pm 1{ }^{\circ} \mathrm{C}$ for 24 hours. The data obtained are presented in Table 3 .

It can be seen from Table 3, the level of general microbial contamination of both freshly prepared minced meat and those stored for 24 hours at a temperature of $-5{ }^{\circ} \mathrm{C} \pm 1$ ${ }^{\circ} \mathrm{C}$ did not exceed the permissible levels and was: after the end of the technological process and cooling 5,0 $\times 10^{4} \mathrm{CFU} / \mathrm{g}-$ in all prototypes; and after 24 hours of storage $-6,2 \times 10^{5}$ $\mathrm{CFU} / \mathrm{g}$ in the control and $(5,1-5,8) \times 10^{5} \mathrm{CFU} / \mathrm{g}$ in the samples enriched with $\mathrm{Fe}_{3} \mathrm{O}_{4}$ thate is, on $6,5-19,6 \%$ less than in the control sample. In this case in all experimental samples bacteria of the group of intestinal sticks (BGIS) in $0,001 \mathrm{~g}$, bacteria of the genus Salmonella and L. Monocytogenes were not detected in $25 \mathrm{~g}$. 
Table 3

Microbiological characteristics of the fresh and cooled beef minced meat with the addition of a food additives on the basis of the $\mathrm{Fe}_{3} \mathrm{O}_{4}$ nanopowder ("Magnetofood") compared to the control

\begin{tabular}{|c|c|c|c|c|}
\hline $\begin{array}{c}\text { The } \\
\text { experiment } \\
\text { al samples }\end{array}$ & $\begin{array}{c}\text { (NMAFAnM, } \\
\text { CFU/g) }\end{array}$ & $\begin{array}{c}\text { BGIS, } \\
\text { in } 0,001 \mathrm{~g}\end{array}$ & $\begin{array}{l}\text { Salmonella, } \\
\text { in } 25 \mathrm{~g}\end{array}$ & $\begin{array}{l}\text { L. Monocyto- } \\
\text { genes, in } 25 \mathrm{~g}\end{array}$ \\
\hline *Sample 1 & $5,0 \times 10^{4}$ & missing in $0,001 \mathrm{~g}$ & missing in $25 \mathrm{~g}$ & missing in $25 \mathrm{~g}$ \\
\hline **Sample 1 & $6,2 \times 10^{5}$ & missing in $0,001 \mathrm{~g}$ & missing in $25 \mathrm{~g}$ & missing in $25 \mathrm{~g}$ \\
\hline * Sample 2 & $5,0 \times 10^{4}$ & missing in $0,001 \mathrm{~g}$ & missing in $25 \mathrm{~g}$ & missing in $25 \mathrm{~g}$ \\
\hline ** Sample 2 & $5,8 \times 10^{5}$ & missing in $0,001 \mathrm{~g}$ & missing in $25 \mathrm{~g}$ & missing in $25 \mathrm{~g}$ \\
\hline * Sample 3 & $5,0 \times 10^{4}$ & missing in $0,001 \mathrm{~g}$ & missing in $25 \mathrm{~g}$ & missing in $25 \mathrm{~g}$ \\
\hline ** Sample 3 & $5,2 \times 10^{5}$ & missing in $0,001 \mathrm{~g}$ & missing in $25 \mathrm{~g}$ & missing in $25 \mathrm{~g}$ \\
\hline * Sample 4 & $5,0 \times 10^{4}$ & missing in $0,001 \mathrm{~g}$ & missing in $25 \mathrm{~g}$ & missing in $25 \mathrm{~g}$ \\
\hline ** Sample 4 & $5,1 \times 10^{5}$ & missing in $0,001 \mathrm{~g}$ & missing in $25 \mathrm{~g}$ & missing in $25 \mathrm{~g}$ \\
\hline Standard & $1 \times 10^{6}$ & not allowed & not allowed & not allowed \\
\hline
\end{tabular}

Note. ${ }^{*}$ - fresh beef minced meat

**_cooled beef minced meat

Reducing of the total microbial contamination in the cooled meat minced meat indicates the bacteriostatic effect on the food additive based on $\mathrm{Fe}_{3} \mathrm{O}_{4}$ nanopowder ("Magnetofood"). The obtained data also indicates that the meat minced from the beef enriched with "Magnetofood" when stored in a refrigerated state for 24 hours, complied with the requirements of the microbiological standards established for this type of product $[40,44,45]$.

The most complete picture of some essential aspects of the quality of meat stuffings is the physical properties that depend on the biological and chemical composition (formulation) and the internal structure (product structure). Minor changes in these defining characteristics should cause the significant changes in the properties values that are registered by devices. At the same time the characteristics of the meat raw materials determine the main indicators of finished products. One of the groups of such indicators include structural - mechanical (rheological) properties.

Table 4 shows the results of determining the depth of immersion and (or the degree of penetration), $\mathrm{h}$ and the marginal displacement stress, $\theta^{0}$.

From the experimental data of Table 4 it follows that with the increase in the angle of the cone, the marginal shear stress $\left(\theta^{0}\right)$ decreases for all experimental samples of the minced meat. At the same time $\theta^{0}$ in the experimental sample of 3 meat minced with a food additive based on $\mathrm{Fe}_{3} \mathrm{O}_{4}$ nanopowders ("Magnetofood") in the optimum amount of $0,10 \%$ by the meat weight is less than $26 \%$ on average than in the control sample minced without $\mathrm{Fe}_{3} \mathrm{O}_{4}$. This indicates a softer and tender consistency of the beef minced with the addition of a nutritional supplement based on $\mathrm{Fe}_{3} \mathrm{O}_{4}$ nanopowders.

When forming a monolithic structure of the crushed meat the index of stickiness or adhesion (Ro) is the great importance $[25,28]$. The research of stickiness for example, the sausage minced allows you to determine the optimal time of rubbing. Similarly in the state of the meat surface it is possible with a certain plausibility to assess its water-holding capacity. Stickiness is associated with other phenomena and products properties: adhesion, cohesion, viscosity and surface friction $[48,51]$. 
Table 4

Structural - mechanical properties of the beef minced meat with the addition of the food additive based on $\mathrm{Fe}_{3} \mathrm{O}_{4}$ nanopowder ("Magnetofood") compared with the control.

\begin{tabular}{|c|c|c|c|c|c|c|c|c|c|c|c|}
\hline \multicolumn{2}{|c|}{$\begin{array}{c}\text { The } \\
\text { angle of } \\
\text { the cone } \\
\alpha, \text { deg. }\end{array}$} & \multirow[t]{2}{*}{$\begin{array}{r}\text { Load } \\
F, \mathrm{H}\end{array}$} & \multicolumn{2}{|c|}{$\begin{array}{c}\text { Depth of } \\
\text { immersion } \\
h, \mathrm{~mm}\end{array}$} & \multicolumn{2}{|c|}{$\begin{array}{l}\text { Average } \\
\text { depth } \\
\text { diving } \\
h_{\text {av }} \mathrm{mm}\end{array}$} & \multicolumn{5}{|c|}{$\begin{array}{c}\text { Tensile displacement of the } \\
\text { experimental samples of the beef } \\
\text { minced meat } \theta_{0}, \mathrm{~Pa} \\
\text { "A"/ "B" }\end{array}$} \\
\hline & & & $\begin{array}{l}\text { Sample } \\
1 \text { or } \\
\text { "A"A" }\end{array}$ & $\begin{array}{l}\text { Sample } \\
3 \text { or } \\
\text { "B" }\end{array}$ & "A" & "B" & $C_{\alpha 1}$ & $C_{\alpha 2}$ & $C_{03}$ & $C_{04}$ & $C_{\alpha 5}$ \\
\hline \multirow{3}{*}{$30^{\circ}$} & 1 & 0,25 & 4,65 & 4,25 & \multirow{3}{*}{4,70} & \multirow{3}{*}{4,20} & \multirow{3}{*}{$\begin{array}{l}12,5 \\
19,5\end{array}$} & \multirow{3}{*}{$\begin{array}{l}12,0 \\
/ 9,0\end{array}$} & \multirow{3}{*}{$\begin{array}{l}11,5 \\
/ 8,5\end{array}$} & \multirow{3}{*}{$\begin{array}{l}11,8 \\
/ 8,9\end{array}$} & \multirow{3}{*}{$\begin{array}{l}12,2 \\
/ 8,4\end{array}$} \\
\hline & 2 & 0,25 & 4,70 & 4,20 & & & & & & & \\
\hline & 3 & 0,25 & 4,75 & 4,30 & & & & & & & \\
\hline \multirow{3}{*}{$60^{\circ}$} & 1 & 0,15 & 4,20 & 3,25 & \multirow{3}{*}{4,15} & \multirow{3}{*}{3,20} & \multirow{3}{*}{$\begin{array}{c}7,5 \\
/ 6,0\end{array}$} & \multirow{3}{*}{$\begin{array}{r}7,0 \\
15,8\end{array}$} & \multirow{3}{*}{$\begin{array}{r}6,5 \\
15,3\end{array}$} & \multirow{3}{*}{$\begin{array}{c}6,8 \\
15,7\end{array}$} & \multirow{3}{*}{$\begin{array}{c}7,4 \\
15,6\end{array}$} \\
\hline & 2 & 0,15 & 4,15 & 3,20 & & & & & & & \\
\hline & 3 & 0,15 & 4,25 & 3,15 & & & & & & & \\
\hline \multirow{3}{*}{$* *$} & 1 & 0,50 & 12,90 & 9,65 & \multirow{3}{*}{12,85} & \multirow{3}{*}{9,70} & \multirow{3}{*}{$\begin{array}{l}16,5 \\
/ 11,0\end{array}$} & \multirow{3}{*}{$\begin{array}{l}16,0 \\
/ 10,5\end{array}$} & \multirow{3}{*}{$\begin{array}{l}15,5 \\
/ 10.0\end{array}$} & \multirow{3}{*}{$\begin{array}{c}15,8 \\
/ 10,4\end{array}$} & \multirow{3}{*}{$\begin{array}{l}16,2 \\
/ 10,3\end{array}$} \\
\hline & 2 & 0,50 & 12,85 & 9,70 & & & & & & & \\
\hline & 3 & 0,50 & 12,80 & 9,75 & & & & & & & \\
\hline
\end{tabular}

*Note. ** - thin core; sample 1 or "A" is the control sample of the beef minced (without "Magnetofood"); sample 3 or "B" is the sample of the beef minced with the addition of a rational quantity of "Magnetofood"- $0,10 \% ; \mathrm{C}_{\alpha}$ is the value of the constant of the cone for the different angles of the cone $\left(30^{\circ} / 60^{\circ}\right):\left(\mathrm{C}_{\alpha 1}=1,1100,415-\mathrm{P}\right.$. A. Rebinder; $\mathrm{C}_{\alpha 2}=0,959 / 0,214-\mathrm{M}$. M. Agranat, M. F. Shirokov; $\mathrm{C}_{\alpha 3}=0,456 / 0,164-$ V.O. Aret, O.N. Pirogov, $\mathrm{C}_{a 4}=0,663 / 0,213-$ A. V. Gorbatov, V. D. Kosoy.; $\mathrm{C}_{\alpha 5}=0,976 / 0,210-$ V. D. Karpichev, V.D. Kosoy.

The results of the research of stickiness content of the beef minced meat with the addition of a nutritional additive based on $\mathrm{Fe}_{3} \mathrm{O}_{4}$ nanopowders ("Magnetofood") as compared to the control are given in Table 5 and Figure 3.

Table 5

The stickiness of the beef mince with the addition of a dietary additive based on $\mathrm{Fe}_{3} \mathrm{O}_{4}$ nanopowder ("Magnetofood") compared with the control

\begin{tabular}{|c|c|c|}
\hline $\begin{array}{c}\text { The experimental sample } \\
\text { of the beef mince }\end{array}$ & $\begin{array}{c}\text { Contact pressure, } \\
\mathbf{R}_{\mathbf{K}} \times \mathbf{1 0}^{-\mathbf{4}}, \mathbf{H} / \mathbf{M}^{\mathbf{2}}\end{array}$ & $\begin{array}{c}\text { Stickiness, } \\
\mathbf{R}_{\mathbf{0}} \times \mathbf{1 0}^{-\mathbf{4}}, \mathbf{P a}\end{array}$ \\
\hline Sample1-control & 0,80 & 0,60 \\
\hline Sample 2 & 0,86 & 0,75 \\
\hline Sample 3 & 0,92 & 0,80 \\
\hline Sample 4 & 1,29 & 0,85 \\
\hline
\end{tabular}

The analysis of data in Table 5 and Figure 2 shows that the use of beef minced meat on the basis of $\mathrm{Fe}_{3} \mathrm{O}_{4}$ nanopowder by helping to increase the stickiness content of meat minced meat at $(0,15-0,25) \times 10^{-4} \mathrm{~Pa}$. Moreover with the increase in the mass fraction of the additive on the basis of $\mathrm{Fe}_{3} \mathrm{O}_{4}$ nanopowder ("Magnetofood") the stickiness of the meat mints increases in 1,16-1,42 times compared with the control sample. 


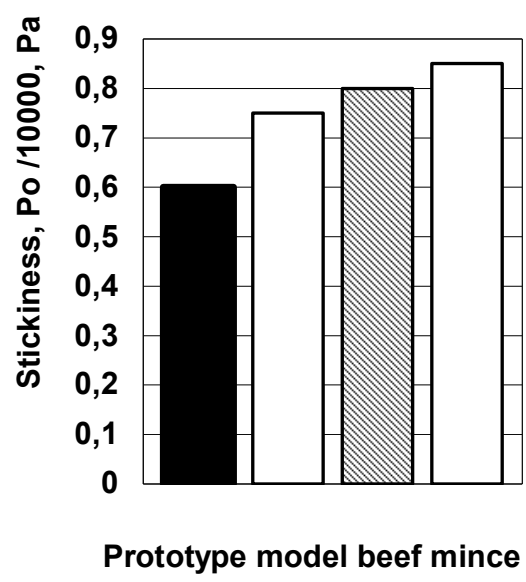

Figure 2. The influence of nutritional additive based on $\mathrm{Fe}_{3} \mathrm{O}_{4}$ nanopowder ("Magnetofood") on the stickliness of the experimental samples of the beef minced meat

This is probably due to the intracellular enzymes activation as a result of the interaction of the ionogenic groups of their proteins with polarized $\mathrm{Fe}_{3} \mathrm{O}_{4}$ nanoparticles and the formation of the "biopolymer matrix of the enzyme - the nanoparticle of the magnetofoot $\left(\mathrm{Fe}_{3} \mathrm{O}_{4}\right)$ " [38, 39].

The complex of the structural and mechanical indicators of the crushed raw material is the information that objectively characterizes the consistency features and is in the close correlation with the specific sensory perception of the latter in the process of disintegration and plasticization of the product in the oral cavity.

The results of research of the nutritional supplement influence on the basis of $\mathrm{Fe}_{3} \mathrm{O}_{4}$ nanopowder ("Magnetofood") on the ultrasound WHC, FRC, EC, ES and on the stickliness of the beef minced meat indicate that the effective action of $\mathrm{Fe}_{3} \mathrm{O}_{4}$ additive nanoparticles is based on the technological characteristics of the meat filling systems.

The investigated technological properties of the beef minced meat make it possible to consider the rational mass fraction of a food additive on the basis of $\mathrm{Fe}_{3} \mathrm{O}_{4}$ nanopowder ("Magnetofood") of $0,10 \%$ to the meat mass.

\section{Conclusion}

The results of the sensory analysis of beef minced meat with the addition of the food additive based on $\mathrm{Fe}_{3} \mathrm{O}_{4}$ nanopowder ("Magnetofood") showed the improvement in the sensory characteristics of the experimental samples of the beef minced meat - the average score for sensory indicators increased by 1,0-1,2 points compared to the control.

The losses reduction during the heat treatment of chilled minced meat with addition of $0,05-0,15 \% \mathrm{Fe}_{3} \mathrm{O}_{4}$ by $14,4-18,4 \%$ was established due to the ability of $\mathrm{Fe}_{3} \mathrm{O}_{4}$ nanoparticles to the electrostatic and coordination interaction with proteins of the minced meat systems [29, 39, 40]. This leads to a change in the moisture content in the experimental samples of the beef minced meat for the increasing in the water-holding capacity of minced meat and better distribution and content of $\mathrm{H}_{2} \mathrm{O}$ and, as a result, a decrease in losses during the heat treatment. 
It is proved that the addition of $0,05-0,15 \%$ to the food additive on the basis of the $\mathrm{Fe}_{3} \mathrm{O}_{4}$ nanopowder ("Magnetofood") has a positive effect on the functional and technological properties of minced beef. In particular, in the experimental samples of the fresh minced meat there is a gradual increase in all functional and technological indicators with an increase in the mass fraction of $\mathrm{Fe}_{3} \mathrm{O}_{4}$ compared to the control: the WHC increases by $1,1 \%-2,0 \%$; FRC $-1,2-2,6 \%$; EC - 1,3-2,0\%; ES - 1,4-2,1\%.

Similar dynamics and in the experimental models of the chilled beef from beef after 24 hours of storage at $5^{\circ} \mathrm{C} \pm 1{ }^{\circ} \mathrm{C}$ only in all cases of their value dropped by $1,3 \%$ to $2,0 \%$ compared to freshly prepared minced meat.

This is probably due to the surface-active sorption, the complex-forming properties of ionized nanoparticles of the food additive "Magnetofood", as well as its affinity with protein molecules $[39,40]$. Therefore, the introduction of the food additive based on $\mathrm{Fe}_{3} \mathrm{O}_{4}$ nanopowder ("Magnetofood") to the minced meat increases the level of moisture and fat and the formation of the stable minced emulsions, in particular, with the lipid and protein components of minced meat systems.

The microbiological characterization of prototypes of the chilled beef from beef showed that the introduction of food additives on the basis of the $\mathrm{Fe}_{3} \mathrm{O}_{4}$ nanopowder ("Magnetofood") in the amount of $0,05-0,15 \%$ by weight of the meat after 24 hours storage reduces the level of total microbial contamination from $6,2 \times 10^{5} \mathrm{CFU} / \mathrm{g}$ in control to $(5,1-$ $5,8) \times 10^{5} \mathrm{CFU} / \mathrm{g}$ in the samples enriched "Magnetofood", that is, $6,5-19,6 \%$.

The positive influence of the dietary additives on the basis of $\mathrm{Fe}_{3} \mathrm{O}_{4}$ nanopowder ("Magnetofood") on the structural and mechanical properties of the minced meat from beef:

1) the shear stress reduction limit to $26 \%$ compared to the control sample, i.e. the beef minced meat with the introduction of the food additive $\mathrm{Fe}_{3} \mathrm{O}_{4}$ has a softer and gentler consistency than the control;

2 ) the stickiness increasing of the minced meat by $(0,15-0,25) \times 10^{-4} \mathrm{PA}$. Moreover, with the mass fraction increase of $\mathrm{Fe}_{3} \mathrm{O}_{4}$ nanopowder ("Magnetofood") stickiness of the minced meat increased $1,16-1,42 \%$ compared to control.

This is probably connected with the activation of intracellular enzymes due to their interactions of ionogenic groups of the components of the minced meat with the polarized nanoparticlesof the food additives on the basis of the $\mathrm{Fe}_{3} \mathrm{O}_{4}$ nanoparticles ("Magnetofood") and the formation of complexes "boolen matrix enzyme $-\mathrm{Fe}_{3} \mathrm{O}_{4}$ nanoparticles" [38, 39].

The rational mass fraction of food additives on the basis of $\mathrm{Fe}_{3} \mathrm{O}_{4}$ nanopowders ("Magnetofod") is established, which provides the best complex of technological properties of forage systems and the smallest losses in heat treatment, it is $0,10 \%$ to the mass of meat.

\section{References}

1. Khamagaeva I.S., Krivonosova A.V., Kuznetsova O.S. (2009), Biologicheski aktivnye dobavki, obogashchennye essentsialnymi mikroelementami, VSGTU, Ulan-Ude.

2. Khamagaeva I.S. (2014), Probioticheskie biologicheski aktivnye dobavki, VSGUTU, Ulan-Ude.

3. Nikitina A.V. Azarova N.G., Tkachuk M.M. (2010), Miasnye polufabrikaty funktsionalnogo naznacheniia, Naukovi pratsi Odesskoi natsionalnoi akademii pishchevykh tekhnologii, 46(2), pp. $168-170$.

4. Potipaeva N.N., Gurinovich G.V., Patrakova I.S., Patshina M.V. (2008), Pishchevye dobavki $i$ belkovye preparaty dlia miasnoi promyshlennosti, Kemerovo.

5. Sarafanova L.A. (2007), Primenenie pishchevykh dobavok v pererabotke miasa i ryby, Professiia, Sankt-Peterburg. 
6. Semenova A.A. (2011), Primenenie pishchevykh dobavok v miasnoi promyshlennosti, Pishchevye ingredienty. Syre i dobavki, 1, pp. 31-35.

7. Bagriantseva O.V., Shatrov G.N. (2013), O bezopasnosti ispolzovaniia glutamata natriia v pishchevykh produktakh, Pishchevye ingredienty. Syre i dobavki, 2, pp. 47-50.

8. Khvylia pp.I., Parshenkova R.V. Primenenie polisakharidov v miasnoi promyshlennosti i ikh vyiavlenie, Miasnye tekhnologii, 1(11), pp. 42-49.

9. Ayadi M.A., Kechaou A., Makni I., Attia H. (2009), Influence of carrageenan addition on turkey meat sausage properties, Journal of Food Engineering, 93(3), pp. 278-283.

10. Dolgova V.A., Khramova I.S., Chmulev V.N. (2012), Effektivnost vvedeniia laktulozosoderzhashchikh BAD v retseptury izdelii kolbasnykh varenykh, Sovremennye naukoemkie tekhnologii, 3, pp. 53-54.

11. Shipulin V.I. (2009), Printsipy razrabotki alternativnykh variantov ratsionalnykh tekhnologii miasnykh produktov novogo pokoleniia s adaptirovannymi pishchevymi dobavkami, Stavropol.

12. Gorshunova K.D., Semenova P.A., Bessonov V.V. Gorshunova K. D. (2012), Interaction of hydrocolloids and water-soluble vitamins in the design of enriched foods, Food Industry, 11, pp. 46-49.

13. Phillips G. O., Williams P. A., (2009), Handbook of hydrocolloids, Woodhead Publishing.

14. Herbacel A.Q. (2013), Plus Citrus Fibers, Type N: Specification for Food Additives and Recipes.

15. María J. Beriain, Inmaculada Gómez, Francisco C. Ibáñez, Victoria M. Sarriés, Ordóñez Ana I. (2018), Chapter 1 - Improvement of the Functional and Healthy Properties of Meat Products, Food Quality: Balancing Health and Disease, Handbook of Food Bioengineering, P.1.

16. Domoroshchenkova M. L., Demyanenko T.Ф., Kamysheva I. M. (2007), Research of functional and technological properties of isolates of soy proteins and others, Oil and fat industry, 4, pp. 24-28.

17. Carla María Blanco-Lizarazo, Rubén Betancourt-Cortés, Angélica Lombana, Katerine CarrilloCastro, Indira Sotelo-Díaz (2017), Listeria monocytogenes behaviour and quality attributes during sausage storage affected by sodium nitrite, sodium lactate and thyme essential oil, Trends in Food Science \& Technology, 23(3), pp. 277-288.

18. Weerapong Woraprayote, Yuwares Malila, Supaluk Sorapukdee, Adisorn Swetwiwathana (2016), Wonnop Visessanguan Bacteriocins from lactic acid bacteria and their applications in meat and meat products, Food Research International, Trends in Food Science \& Technology, 120, pp.118-132.

19. Lai W. T., Khong N. M. H., Lim pp. pp., Hee Y. Y., Sim B. I., Lau K. Y., Lai O. M. (2016). A review: Modified agricultural by-products for the development and fortification of food products and nutraceuticals, Trends in Food Science \& Technology, pp. 59, 148 - 160.

20. José Manuel Lorenzo, Mirian Pateiro, Rubén Domínguez, Francisco J.Barba, Predrag Putnik, Danijela Bursać Kovačević, Avi Shpigelman, Daniel Granato, Daniel Francoa (2018), Berries extracts as natural antioxidants in meat products: A review, Food Research International. Trends in Food Science \& Technology, 106, pp. 1095-1104.

21. Camila de Souza Paglarini, Guilherme de Figueiredo Furtado, João Paulo Biachi, Vitor Andre Silva Vidal, Marise Aparecida Rodrigues Pollonio (2018), Functional emulsion gels with potential application in meat products, Journal of Food Engineering, Vol. 222, pp. 29 - 37.

22. Yu-Feng Wang, Jin-Xia Jia, You-Qiu Tian, Xu Shu, Zhi-Yong Yan. Antifungal effects of clove oil microcapsule on meat products, LWT. Trends in Food Science \& Technology, 89, pp. 604-609.

23. Karna Ramachandraiah, Mi-Jung Choi, Geun-Pyo Hong (2018), Micro- and nano-scaled materials for strategy-based applications in innovative livestock products: A review, Trends in Food Science \& Technology, 71, pp. 25-35.

24. Ilyukha N. G., Barsova Z. V., Kovalenko V. A., Tsykhanovskaya I. V. (2010), Tekhnologiya proizvodstva i pokazateli kachestva pishchevoy dobavki na osnove magnetita, VostochnoYevropeyskiy zhurnal peredovykh tekhnologiy, 10(48), pp. 32-35.

25. Aleksandrov O. V., Tsykhanovs'ka I. V., Hontar T. B., Barsova Z. V., Kokodiy, M. H. (2016), Doslidzhennya nanochastynok mahnetytu lipido-mahnetytovykh suspenziy metodamy fotometriyi i elektronnoyi mikroskopiyi, Vostochno-Evropeyskyy zhurnal peredovykh 
tekhnolohyy, 6,3(81), pp. 28-38.

26. Tsykhanovs'ka I. V., Aleksandrov O. V., Evlash V. V., Lazareva T. A., Svydlo K. V., Hontar T. B. (2017), Rozrobka tekhnolohiyi zhytn'o-pshenychnoho khliba «Kharkivs'kyy rodnychok» z dodavannyam polifunktsional'noyi kharchovoyi dobavky «Mahnetofud», VostochnoEvropeyskyy zhurnal peredovykh tekhnolohyy, 6,11(90), pp. 48-58.

27. Tsykhanovska I., Alexandrov A., Evlash V., Lazareva T., Svidlo K., Gontar T. (2018), Formation of the quality of the rzhno-wheat bread with addition of the polyfunktanial food additives "Magnetofood", New Technologies of Food Production: Raw Materials, Additives, Quality, Lambert Academic Publishing.

28. Tsykhanovska I., Alexandrov A., Evlash V., Svidlo K., Gontar T. (2017), «Magnetofood»-food supplement, «Eureka: Life Sciences», 5, pp. 45-52.

29. Aleksandrov O.V., Tsykhanovs'ka I. V., Barsova Z. V., Dudenko N.V., Pavlots'ka L.F., Skurikhina L. A. (2015), Oderzhannya ta doslidzhennya vlastyvostey biolohichno-aktyvnykh dobavok na osnovi lipido-mahnetytovykh suspenziy, Povnotsenne kharchuvannya: innovatsiyni aspekty tekhnolohiyi, enerhoefektyvnoho vyrobnytstva, zberihannya ta marketynhu, Kharkiv.

30. Tsykhanovska I., Alexandrov A., Gontar T., Kokodiy N., Dotsenko N. (2016), Stability and morphological characteristics of lipid-magnetite suspensions, Eureka: Life Sciences, 3, pp. 1425.

31. Ilyukha M. H., Barsova Z.V.,Timofeyeva V. P., Tsykhanovs'kka I.V. Vedernykova I. O. (2009), Nanokhimichna tekhnolohiya mahnetytu, Khimchna promyslovist' Ukrayiny, 5(94), pp. 37-41.

32. Tsykhanovs'ka I. V., Demydov I. M., Barsova Z. V., Pavlots'ka L. F. (2015), Doslidzhennya protsesiv okysnyuval'nykh ta termichnykh peretvoren' v systemi: oliya-lipido-mahnetytova suspenziya, Prohresyvna tekhnika ta tekhnolohiyi kharchovykh vyrobnytstv restorannoho hospodarstva i torhivli, 1(21), pp. 353-362.

33. Tsykhanovs'ka I. V., Demydov I. M., Aleksandrov O. V., Hontar T. B., Pavlots'ka L. F. (2017), Doslidzhennya vplyvu biolohichno aktyvnoyi dobavky na protsesy okysnennya lipidiv, Prohresyvna tekhnika ta tekhnolohiyi kharchovykh vyrobnytstv restorannoho hospodarstva $i$ torhivli, Kharkiv, 2(26), pp. 251-262.

34. Konyushenko I. pp., Barsova Z. V., Tsykhanovs'ka I. V. (2011), Syntez, fizyko-khimichni doslidzhennya i biolohichna diya mahnetytu na ob'yektakh in vivo, Vseukrayins'kyy konkurs student·s'kykh naukovykh robit za napryamkom "Khimichna tekhnolohiya ta inzheneriya", Donets'k, pp. 54-57.

35. Denisova A. Yu., Tsykhanovskaya I. V., Skorodumova O. B., Levitin Ye. Ya., Kovalenko V. A., Aleksandrov A. V., Barsova Z. V. (2012), Izucheniye rastvorimosti magnetita v usloviyakh, imitiruyushchikh pishchevaritel'nyye protsessy zheludochno-kishechnogo trakta, VostochnoYevropeyskiy zhurnal peredovykh tekhnologiy, 6(60), pp. 29-31.

36. Chaudhry O., Castle P., Watkins R. (2010), Nanotechnoiogy in food, RSC Publishin, New York.

37. Polumbryk M. O. (2011), Nanotekhnolohiyi v kharchovykh produktakh, Kharchova promyslovist, 10 , pp. 319-322.

38. Alexandrov A., Tsykhanovska I., Evlash V., Svidlo K., Gontar T. (2017), Influence of the polyfunctional food supplement «Magnetofood» on the quality of the wheat bread bread «Darnitsky» in the storage process, Eastern European Journal of Advanced Technology, 5/11(89), pp. 61-70.

39. Tsykhanovska I., Alexandrov A., Evlash V., Lazareva T., Svidlo K., Gontar T., Yurchenko L., Pavlotska L. (2018), Substantiation of the mechanism of interaction between biopolymers of ryeand-wheat flour and the nanoparticles of the «Magnetofood» food additive in order to improve moisture-retaining capacity of Dough, Eastern European Journal of Advanced Technology, 2/11(92), pp. 70-80.

40. Tsykhanovs'ka I.V., Skurikhina L.A., Aleksandrov O.V., Hontar T.B. (2017), Doslidzhennya vplyvu biolohichno aktyvnoyi dobavky na yakist' m'yasnykh posichenykh napivfabrykativ, Prohresyvni tekhnika ta tekhnolohiyi kharchovykh vyrobnytstv restorannoho hospodarstva $i$ torhivli, 1(25), pp. 302-313.

41. Tsykhanovska I., Alexandrov A., Evlash V., Lazareva T., Svidlo K., Gontar T. (2017), Research into technological indicators of a rye-wheat dough semi-finished product with the 
addition of the polyfunctional food supplement "Magnetofood", Eureka: Life Sciences, 6(14), pp. 43-50.

42. Tsykhanovska I., Alexandrov A., Evlash V., Lazareva T., Svidlo K., Gontar T. (2018), Investigation of the moisture-retaining power of rye-wheat gluten and flour with polyfunctional food supplement "Magnetofood", Eureka: Life Sciences, 2(14), p. 62-76.

43. Shugurova T. O. (2011), Innovacionnyj podhod k proizvodstvu natural'nyh polufabrikatov, Myasnoj biznes, 4, pp. 56-57.

44. Olijnik L.B. (2016), Suchasni napryami vdoskonalennya tekhnologij m'yasnih napivfabrikativ, Naukovij visnik Poltavs'kogo universitetu ekonomiki i torgivli, 1(78), pp. 22-28.

45. Pasichnyi V.M., Heredchuk A. M., Moroz O. O., Yastreba Yu. A. (2015), Doslidzhennia faktoriv prolonhatsii terminiv zberihannia miasnykh i miasomistkykh produktiv, Naukovi pratsi Natsionalnoho universytetu kharchovykh tekhnolohii, 21(4), pp. 224-230.

46. Mansvetova E.V. (2009), Novye podhody v proizvodstve ehmul'girovannyh myasnyh produktov, Pishchevaya promyshlennost', 7, pp. 44-45.

47. Hazenhyutl' Dzh., Gartel R. (2008), Pishchevye ehmul'gatory i ih primenenie, Sankt-Peterburg, pp. 156-159, 168-169.

48. Rogov I. A., Zabashta A. G., Kaziulin G. P. (2000), Obshchaia tekhnologiia miasa $i$ miasoproduktov, Kolos, Moscow.

49. Antipova L. V., Glotova I. A., Rogov I. A. (2004), Metody issledovaniia miasa i miasnykh produktov, Kolos, Moscow

50. Zhuravskaia N. K., Gutnik B. E., Zhuravskaia N. A. (1999), Tekhnokhimicheskii kontrol proizvodstva miasa i miasoproduktov, Kolos, Moscow

51. Klymenko M. M., Vinnikova L. H., Bereza V. H. (2006), Tekhnolohiia myasa ta m yasnykh produktiv, Vyshcha osvita, Kyiv. 


\title{
Chemical composition of fenugreek hay leaves
}

\author{
Vira Obolkina ${ }^{1}$, Tamara Nosenko, \\ Olha Dzyhar ${ }^{1}$, Dzhamal Rakhmetov ${ }^{2}$
}

\section{1- National University of Food Technologies, Kyiv, Ukraine \\ 2 - National botanical garden after M.M. Gryshko of National Academy of Sciences named, Kyiv, Ukraine}

\begin{tabular}{l} 
Keywords: \\
Fenugreek hay \\
Leaves \\
Spices \\
Aromatic \\
Phenolic \\
\hline
\end{tabular}

Article history:

Received

01.06 .2018

Received in

revised form

29.08.2018

Accepted

28.09.2018

\section{Corresponding author:}

Olha Dzyhar

E-mail:

olgadzygar@

gmail.com

DOI:

$10.24263 / 2304-$ 974X-2018-7-3-5

\section{Abstract}

Introduction. It was researched the chemical composition of fenugreek hay leaves which is a source of biologically active substances and used as spice-aromatic raw materials for the confectionery products.

Materials and methods. The chemical composition of fenugreek hay leaves were studied by ultra high-speed high performance liquid chromatography, spectrophotometry and gas chromatography with mass-selective detection. To investigate the composition of leaves extract aglycones acidic hydrolysis was used. After hydrolysis aglycones were extracted by ethylacetate and extracts were used for chromatography. To identify component composition the derivatization method was used.

Results and discussion. The presence of phenolic compounds, phenolcarbonic acids, chlorophylls, trigonoline alkaloids, which have a high antioxidant potential, was confirmed in the chemical composition of fenugreek leaves. It is known that phenolic compounds in plants are rarely found in the free state. Most of them are presented in the form of various $\mathrm{O}$ - and $\mathrm{C}$-glycosides. The diversity of flavonoid glycosides is due to a significant amount of sugars and the different positions of their attachment to the aglycones, as well as the fact that sugars may have different configurations of glycosidic bonds.

It was identified the luksosa, beta-dl-arabinopyranose, sucrose, raffinose, glycerol, xylitol in the fenugreek leaves extracts. The presence of amino acids such as L-alanine, L-valine, L-proline, Lthreonine had been proved in these leaves. The oxyacetic, succinic, 2,3-dioxypropanoic, 2,3,4- threehydroxybutyric acids and fatty palmitic and alpha-linolenic acids were also identified in the leaves extracts.

Fenugreek essential oil contains: hexadecene, eicozanol, ethyl palmitate, ethylinoleate, beta-hydroxy-butyric,beta-aminoizobutyric, hydroxybutanedicarbonic, 1,2,3-propanethreecarbonic acids; ethyl esters of linoleic, levulinic, palmitic, ethylpalmitic, citric acids, which are likely to form a flavor of spicy-aromatic raw materials.

Conclusions. The presence of phenolic compounds, essential nutrients, aromatics in the fenugreek leaves should increase the shelf life, the nutritional value, improve the sensory properties of confectionery. 


\section{Introduction}

Food manufacturers, in particular confectionery products, are increasingly using spicearomatic plant raw materials as a source of biologically active substances (BAS). Essential oils, tannins and phenol substances play an important role in the formation of the flavor, promote the increase of the product shelf life. Besides, bioactive substances of medicinal plant can prevent cardiovascular diseases, carcinogenesis, inflammation, atherosclerosis and other human deseases $[1,2]$.

Leafy vegetable Fenugreek (Trigonella foenum-graecum) has been used as an effective medicinal plant as well as a fodder plant. Leaves of fenugreek hay have the aroma and antioxidant properties and pleasant taste [3-6]. It was shown that the green leaf of Trigonella foenum-graecum influenced the cholesterol balancing, sugar-level, skin inflammation (wounds, rashes, boils), treating arthritis, asthma, sore throat [9]. It was suggested that phytoconstituents such as flavonoids, alkaloids, terpenoids, steroids, saponins, anthocyanin, tannin and other were involved in this effect.

Fenugreek is an annual spice-aromatic plant, belongs to the legumes family. Seeds and leaves of plants contain many antiseptic, antioxidant and anti-inflammatory substances, such as apigenin, genistein, campeferol, quercetin, rutin, selenium, trihonellin alkaloid, iodine and are using in the food industry $[7,8]$. The foliage contain a large amount of bioactive substances: vitamins A, C, B1, B2, B9 (folic acid), nicotinic acid (vitamin PP), rutin, tannins, food fibers, macro and microelements - iron, potassium, phosphorus, magnesium, calcium etc. [10-14].

Phenolic compounds present in plants are rarely found in a free state. Most of them are presented in the form of various O- and C-glycosides. The variety of flavonoid glycosides is due to a significant amount of sugars (glucose, arabinose, xylose, etc.) and the their ability to attach to the position of aglycones, as well as sugars can have different configurations of glycoside bonds. To the best of our knowledge, there were not sufficient data on the composition of carbohydrates, amino acids, fatty acids, aromatic substances of fenugreek hay leaves in the scientific literature, and this substantiates the actuality of the present work.

Consequently, the identification and quantification of phenolic compounds in plant material requires complex researches.

The purpose of this work was to study the chemical composition of the leaves of fenugreek hay, the possibility of its use in the production of a new range of flour confectionery products with high fat content, in particular, crackers and puffy cookies, as a natural antioxidant and a flavoring additive. The presence of antioxidants in the formulation of foods with fat content is very important because they can inhibit the rate of fat oxidation [15]. To determine the classes of organic substances of fenugreek leaves the highperformance liquid chromatography was used.

\section{Materials and methods}

The samples of fenugreek (Trigonella foenum-graecum) leaves have been received from M.M. Grishko National Botanical Garden of National Academy of Sciences of Ukraine. 


\section{Ethanol extract obtaining}

$2.5 \mathrm{~g}$ of dry crushed leaf was putted to a $100 \mathrm{ml}$ flask, $60 \mathrm{ml}$ of $96 \%$ ethanol was added, reversed condenser was attached and flask was heating in a boiling water bath for $90 \mathrm{~min}$. After that, the water bath was cooled, the fridge was washed with $5 \mathrm{ml}$ of ethyl alcohol, and the content of the flask was filtered into a $100 \mathrm{ml}$ measuring flask. Then procedure was repeated with $35 \mathrm{ml}$ of ethanol. The final volume of ethanol extract was adjusted to $100 \mathrm{ml}$.

\section{Obtaining of hydrolyzed extracts}

$0.4 \mathrm{~g}$ of dry crushed leaves were transferred to a $100 \mathrm{ml}$ flask attached by a reversed condenser, $20 \mathrm{ml}$ of ethyl alcohol, $20 \mathrm{ml}$ of distilled water and $10 \mathrm{ml}$ of concentrated hydrochloric acid were added. After attaching the flask to the reversed condenser the mixture was heated for 90 minutes in a boiling water bath. After that, the condenser was washed with $20 \mathrm{ml}$ of distilled water and flask was cooled. The content of the flask was transferred to a $100 \mathrm{ml}$ separate funnel through a paper filter, $25 \mathrm{~g}$ of sodium chloride was added and mixed thoroughly. The organic compounds were extracted with $30 \mathrm{ml}$ of ethyl acetate, the procedure was carried out in two consequent repetitions. After extracts drying with anhydrous sodium sulfate, the ethyl acetate was evaporated by vacuum. After evaporation the residue was dissolved in $50 \mathrm{ml}$ of ethanol.

\section{Ultra high-speed high performance liquid chromatography}

Ultra high-speed high performance liquid chromatography of leave extracts was carried out using HPLC (WATERS (USA), column ACQUITY UPLC ${ }^{8} \mathrm{BEHC}_{18}, 1,7 \mu \mathrm{m}, 50 \times 2,1$ $\mathrm{mm}$ ) with diode-matrix detection (PDA) and gradient changing of the mobile phase (acetonitrile-water) composition.

Organic substances with hydrogen mobile atoms in plants are present in conjugated form and to investigate their composition in forms of aglycones acidic hydrolysis was used. After hydrolysis aglycones were extracted by ethylacetate and extracts were used for chromatography. Composition of remaining ethanol extracts after removal of ethanol were also analyzed [10].

\section{Spectrophotometric analysis}

Spectrophotometric analysis of leave extracts was performed on the spectrophotometer Specord 210 Plus (Germany) [16].

\section{Gas chromatography with mass-selective detection}

To identify component composition of the extracts, the derivatization method was used, which allows to increase the molecular weight of the initial substances. N-methyl-Ntrimethylsilyl-trifluoroacetamide (TMS) reagent was used for derivatization.

For TMS derivatives obtaining $5 \mathrm{ml}$ of ethanol extract was putted into vial and ethyl alcohol was removed by evaporation at $78^{\circ}$ C. $300 \mu \mathrm{g}$ of anhydrous pyridine and $100 \mu \mathrm{g}$ of TMS reagent were added to the dry residue. Vial was sealed and placed in UZB for 30 minutes. After this, $1 \mathrm{ml}$ of acetonitrite was added to the vial, mixed and obtained mixture of derivatives were analyzed on chromatograph Agilent GC/MSD 7890A/5975C with capillary column HP-5MS [13]. 


\section{Results and discussion}

According to electronic absorption spectrum of the samples the phenolic acids (absorption at $326 \mathrm{~nm}$ ), aromatic compounds (absorption in the range 350-600 nm), chlorophylls $(667 \mathrm{~nm})$ were presented in initial leaf extracts of fenugreek (Figure 1).

Displacement of the maxima to the ultraviolet region with an increase of the $\mathrm{pH}$ of the solution (Figure 1,2) indicates the destruction of the intramolecular hydrogen bond under $\mathrm{pH}$ increasing.

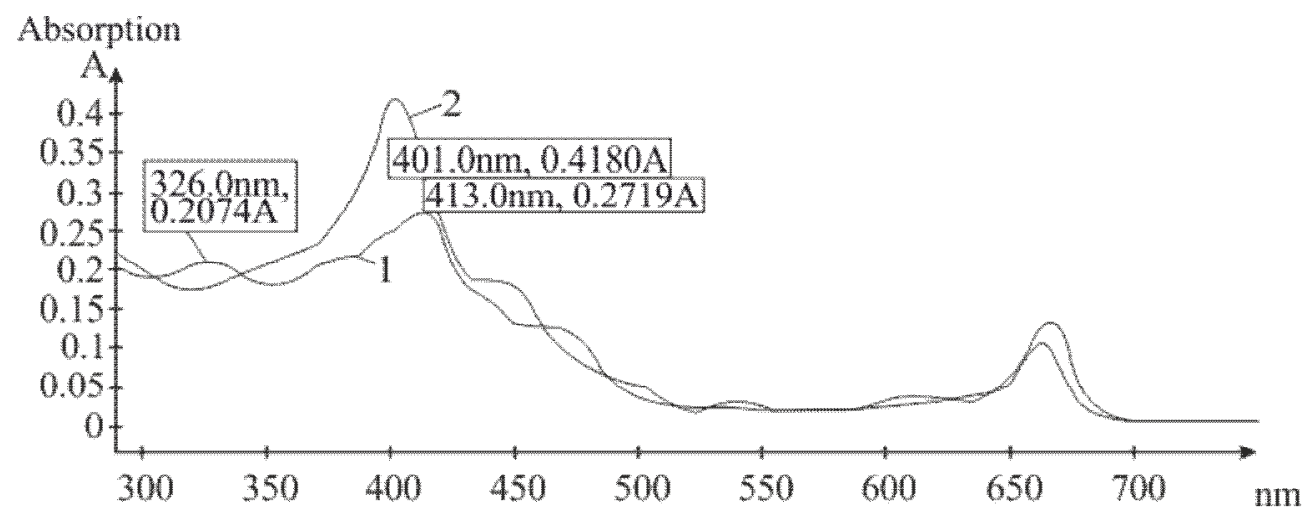

Figure 1. Electronic absorption spectrum of initial leaf extract $(1-\mathrm{pH}=6,5 ; 2-\mathrm{pH}=11,8)$

Ultra high-speed high performance liquid chromatography (UHPLC) of initial leave extracts (Figure 2a and $2 \mathrm{~b}$ ) have demonstrated presence of phenol carboxylic acids (retention time 4.52, 5.59, $6.46 \mathrm{~min}$ ), catechins (retention time 5.24, $5.45 \mathrm{~min}$ ) and alkaloid trihonellin (retention time $6.29 \mathrm{~min}$ ). Eight different substances were identified by this analysis with spectrophotometrical detection at 325.0 and $350 \mathrm{~nm}$ (Table 1).

Content of substances in initial leaf extract according to Figure 2 a, b

Table 1

\begin{tabular}{|c|c|c|c|}
\hline $\begin{array}{c}\text { Retention time, } \\
\text { min }\end{array}$ & $\begin{array}{c}\text { \% from the total } \\
\text { content }\end{array}$ & $\begin{array}{c}\text { Retention time, } \\
\text { min }\end{array}$ & $\begin{array}{c}\text { \% from the total } \\
\text { content }\end{array}$ \\
\hline \multicolumn{2}{|c|}{ PDA 325.0 nm } & \multicolumn{2}{|c|}{ PDA 350.0 nm } \\
\hline 0,983 & 7,7 & 5,241 & 4,8 \\
\hline 4,520 & 54,9 & 5,454 & 17,3 \\
\hline 6,461 & 37,5 & 5,585 & 47,0 \\
\hline- & - & 5,830 & 18,0 \\
\hline- & - & 6,292 & 13,0 \\
\hline
\end{tabular}




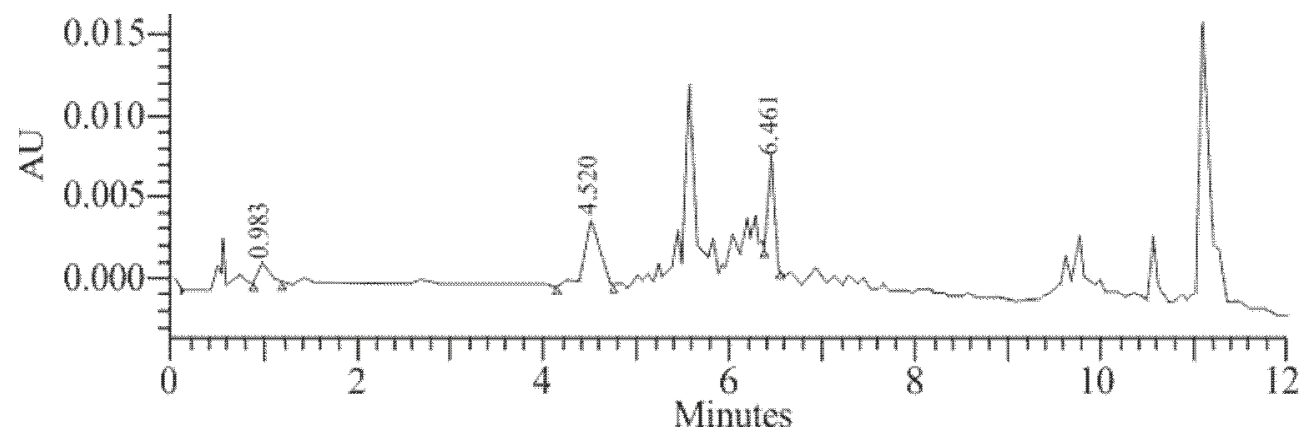

Figure 2a. Chromatogram of initial leaf extract (PDA 325.0 nm).

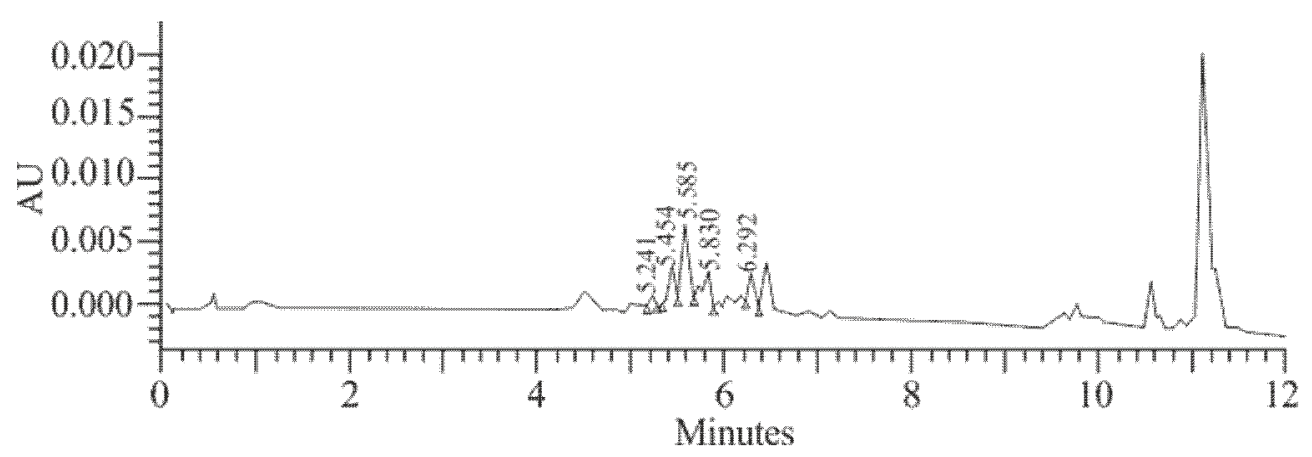

Figure 2b. Chromatogram of initial leaf extract (PDA $350.0 \mathrm{~nm}$ ).

The distribution of peaks and their absolute intensity on the sample electronic absorption spectrum after acid hydrolysis were similar to the original spectrum (Figure 3).

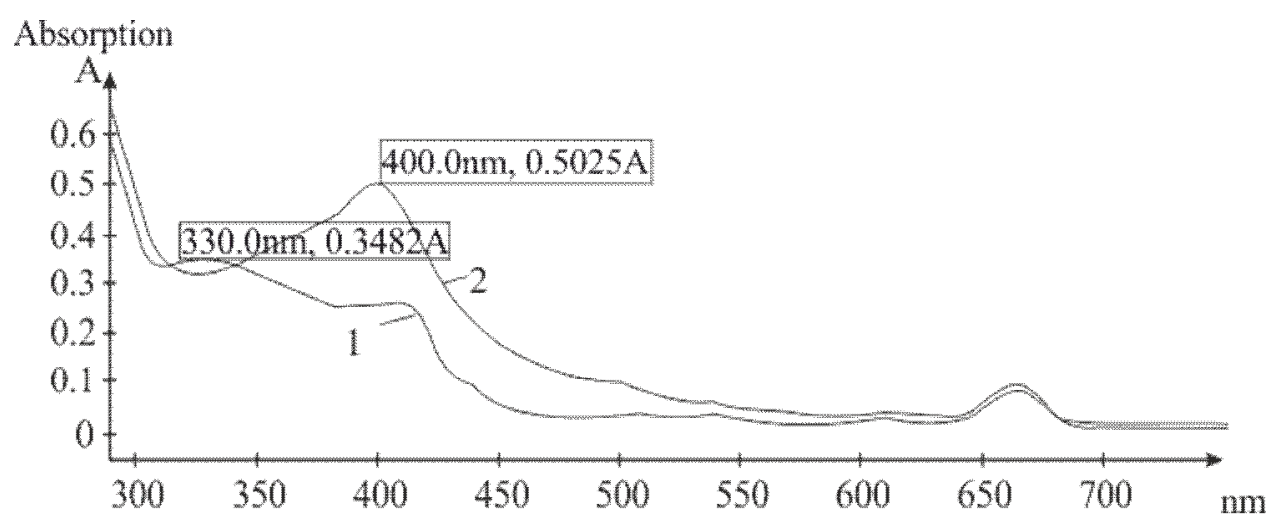

Figure 3. Electronic absorption spectrum of ethylacetate extracts after hydrolysis of leaf extracts $(1-\mathrm{pH}=6,5 ; 2-\mathrm{pH}=11,8)$ 
Analysis of this extracts by HPLC had shown that catechins were destructed under acid hydrolysis of initial leaf extract (Figure 4). Trihonellin was absent in ethylacetate extracts of hydrolyzed initial leaf extracts. The number of new substances were detected after acid hydrolysis, absorbtion peaks of which are close to phenolic acids. Ratio of detected components are presented in Table 2.

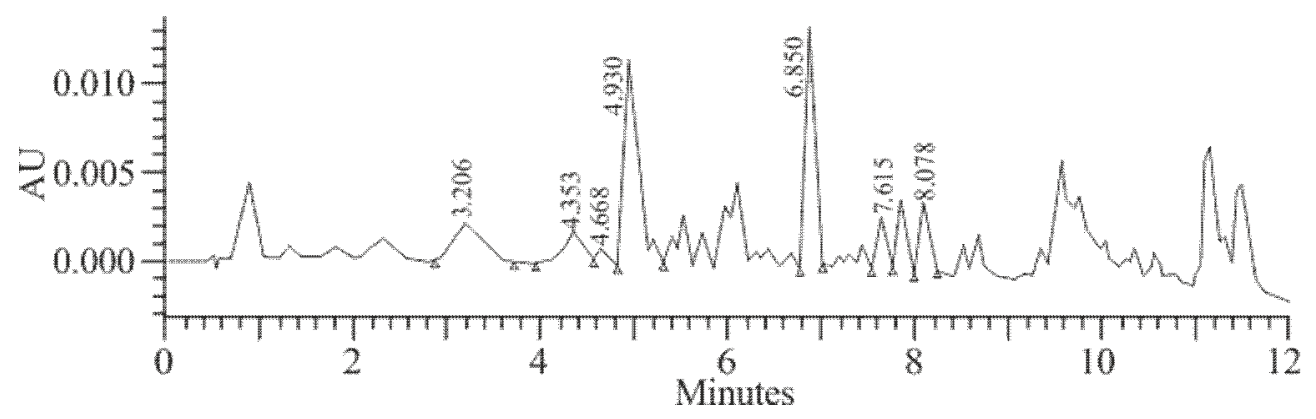

Figure 4. Chromatogramm of ethylacetate extracts after hydrolysis of leaf extracts (PDA 350)

Table 2

Ratio of components ethylacetate extracts after hydrolysis of leaf extracts (PDA $350.0 \mathrm{~nm}$ )

\begin{tabular}{|c|c|c|}
\hline № & Retention time, min & $\begin{array}{c}\text { \% from the total } \\
\text { content }\end{array}$ \\
\hline 1 & 3,206 & 14,84 \\
\hline 2 & 4,353 & 6,65 \\
\hline 3 & 4,668 & 1,30 \\
\hline 4 & 4,930 & 36,90 \\
\hline 5 & 6,859 & 25,02 \\
\hline 6 & 7,615 & 5,66 \\
\hline 7 & 8,078 & 9,63 \\
\hline
\end{tabular}

Using of mass-chromatography for analysis of initial leaf extracts gave possibility to detect number of aliphatic substances mainly hexadecen, linolenic acid and eycosanol (Figure 5).

The mass-chromatogramm of ethylacetate extracts after hydrolysis of leave extracts presented in Figure 6 have demostrated that after acid hydrolysis, a number of compounds appeared: ethyl esters of levulinic acid, ethyl palmitate, ethylinoleate.

The mass-chromatography of ethylacetate extracts after hydrolysis has detected the carbonic acid esters, that are probably the constituent of essential oil of fenugreek. They are the ethyl esters of levulinic acid, ethyl esters of citric acid, 1,2,3-propanetricarboxylic acid ethyl esters, ethyl esters of palmitic, linoleic, beta-hydroxy-butyric and citric acid. 

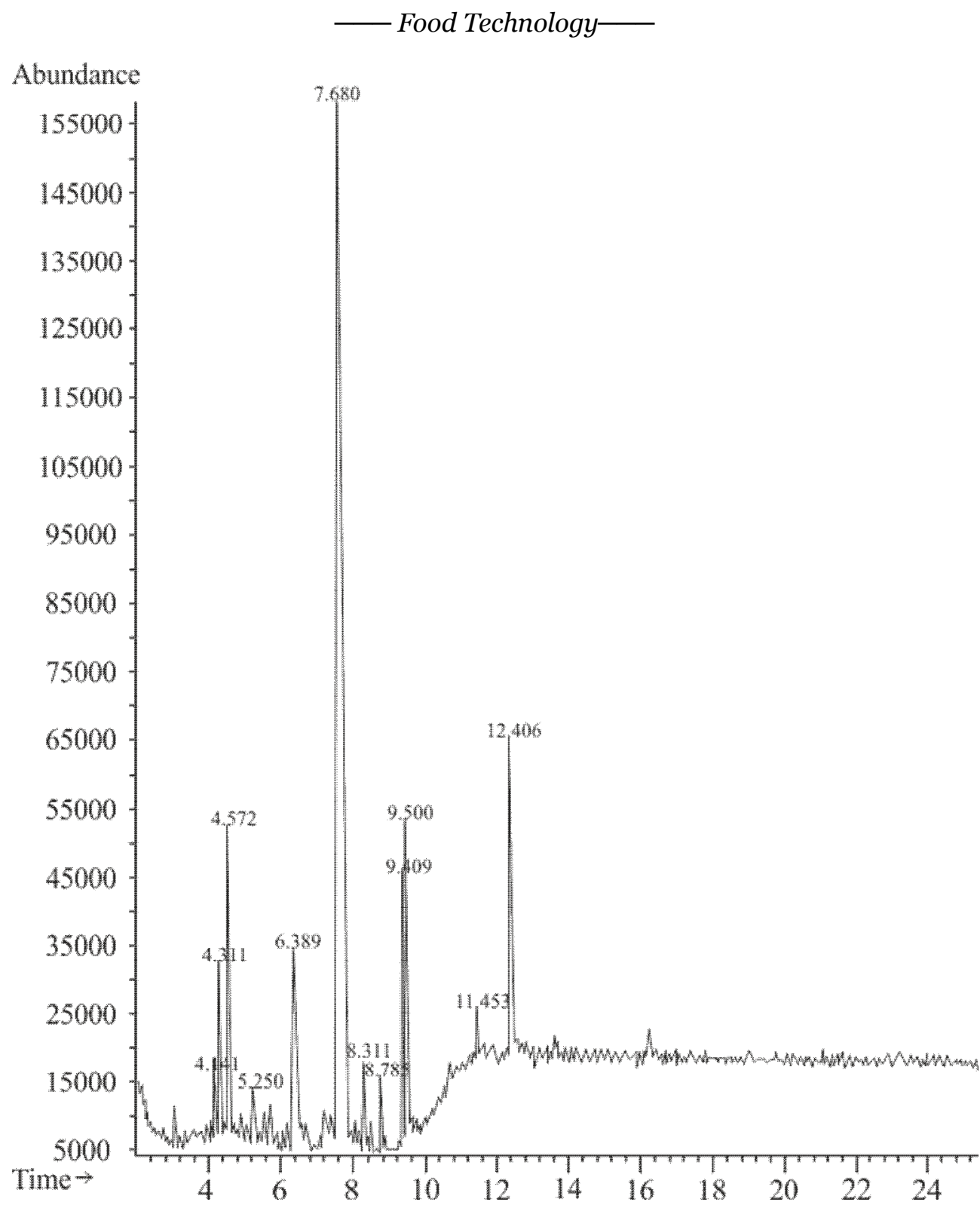

Figure 5. Mass-chromatogramm of initial fenugreek leaf extracts 


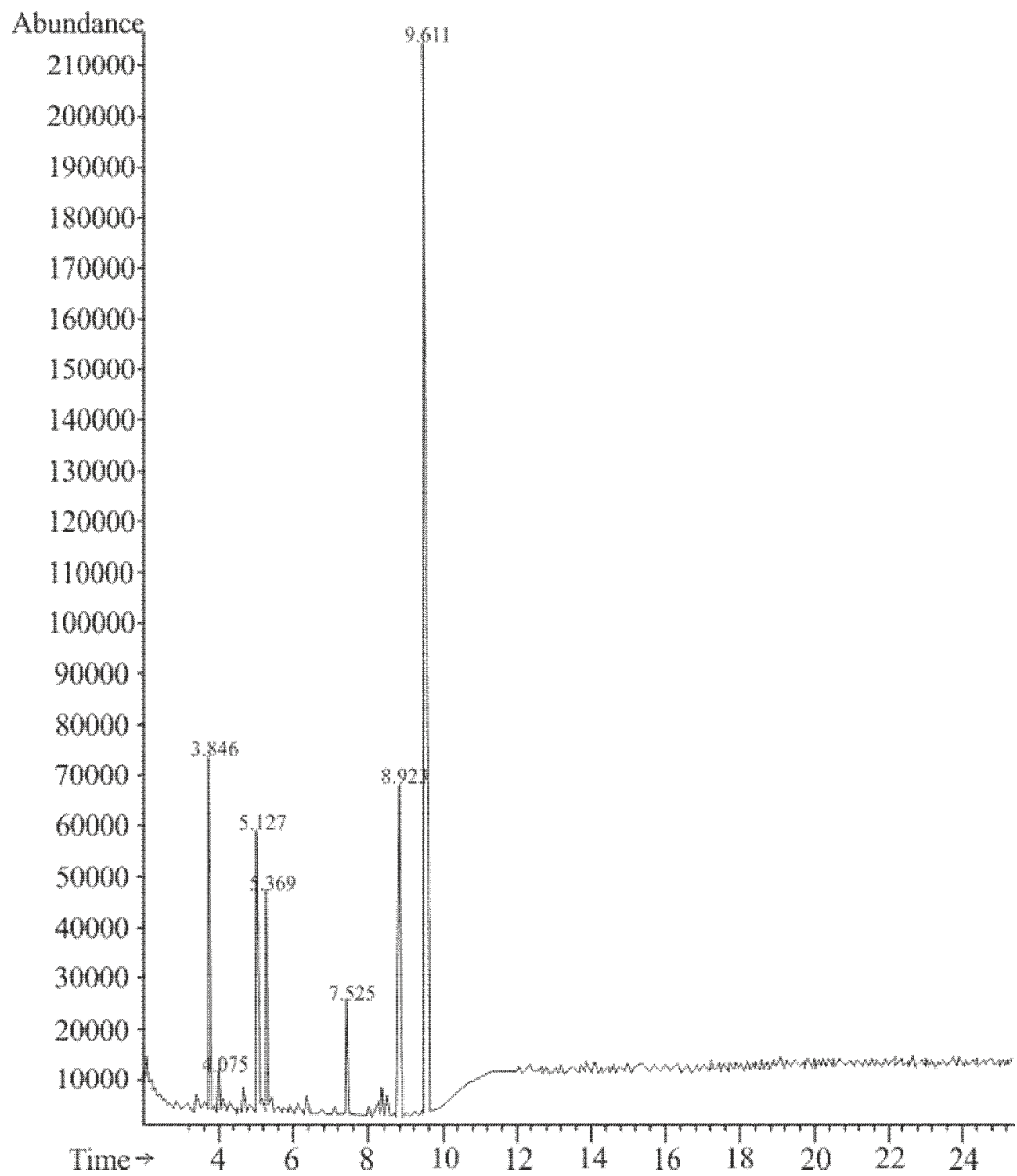

Figure 6. Mass-chromatogramm of ethylacetate extracts after hydrolysis of fenugreek leaf extracts

To identify component with low molecular weight derivatization method was used and amino acids L-alanine, L-valine, L-proline, L-threonine, a number of carbohydrates, mainly lyksosa, $\beta$-dl-arabinopyranose, sucrose and raffinnose were detected in initial fenugreek leaf extracts (Figure7). The oxoacetic acid, succinic acid, 2,3-dioxypropane acid, 2,3,4 trihydroxybutyric acid, palmitic acid, $\alpha$-linolenic acid, as well as glycerol and xylitol were identified in these extracts after derivatization. 
Abundance

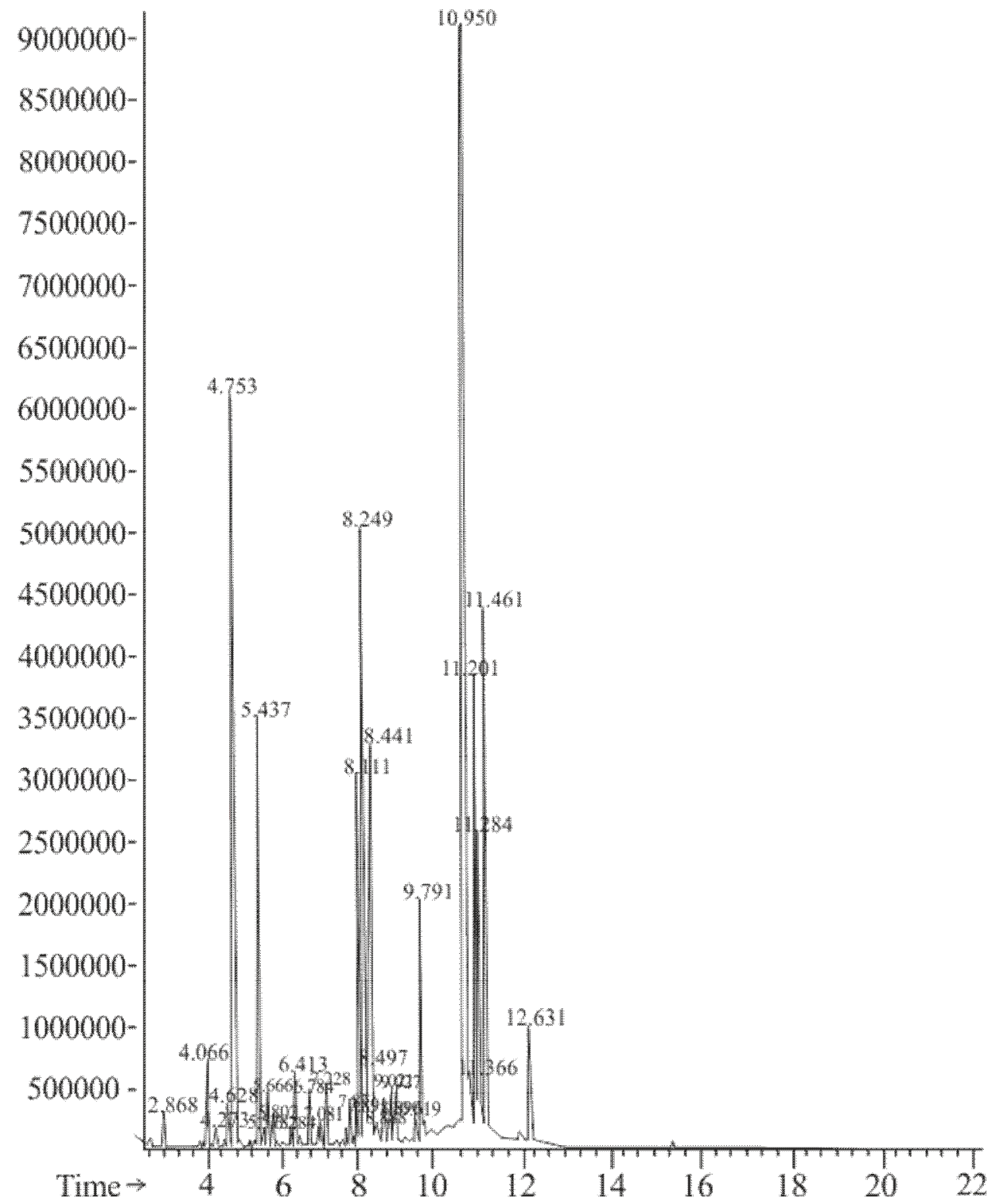

Figure 7. Mass-chromatogramm of TMS derivates of initial ethanol extracts of fenugreek leaf

The TMS derivates of constituents of fenugreek leaf extracts were obtained also after acidic hydrolysis. Mass-chromatogramm of TMS derivates of fenugreek leaf extracts after acidic hydrolysis have demonstrated presence of $\beta$-hydroxybutyric acid, betaaminoisobutyric acid, hydroxybutanedicarboxylic acid, citric acid, ethyl ester of palmitic 
and linoleic acid (Figure 8). The intense $(2,499 \mathrm{~min})$ peak is due to the interaction of the destruction product of the reagent (methylamine) with the reagent.

Therefore, using ultra high-speed high performance liquid chromatography, spectrophotometry, gas chromatography with mass-selective detection it was shown the presence of phenolic carboxylic acids, flavonoid compounds, trihonellin alkaloids, which have a high antioxidant potential, the components of fenugreek essential oils, sugars, amino acids and aromatic substances in fenugreek leaf.

Abundance

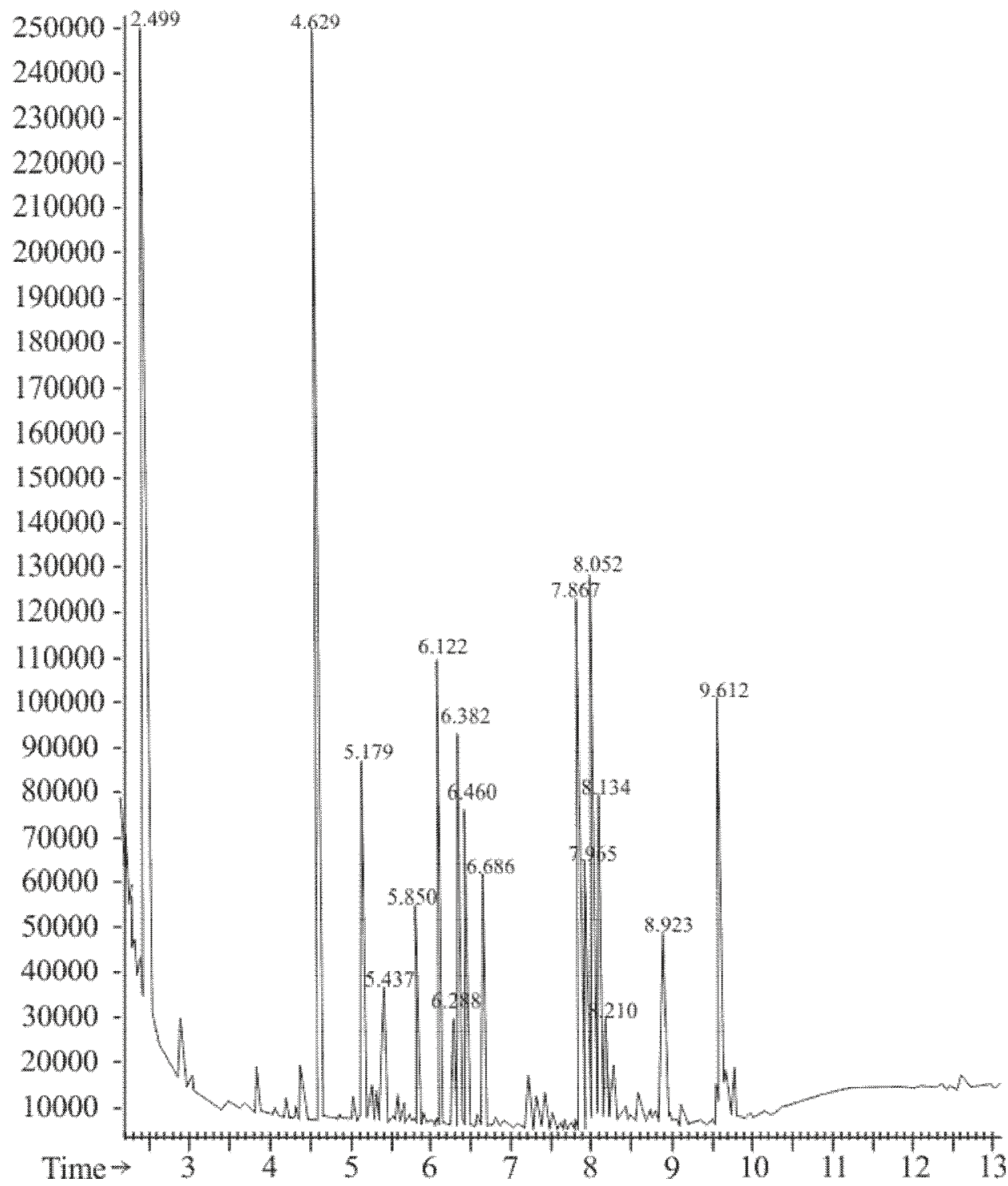

Figure 8. Mass-chromatogramm of TMS derivates of fenugreek leaf extracts after acidic hydrolysis 


\section{Conclusion}

1. For the first time by application of spectrophotometry method with reference to electronic absorption spectrum we were able to identify the phenolic acids (absorption at $326 \mathrm{~nm}$ ), aromatic compounds (absorption in the range 350-600 nm), chlorophylls (667 $\mathrm{nm}$ ) in initial leaf extracts of fenugreek.

2. By conducting analysis of this extracts by HPLC it was shown destruction of catechins and absent of trihonellin in ethylacetate extracts. New identified substances judging from absorption peaks are close to phenolic acids.

3. Mass-chromatography allowed us to recognize in fenugreek leaf extracts after acid hydrolysis a number of compounds: ethyl esters of levulinic acid, ethyl palmitate, ethylinoleate. However, alongside we found carbonic acid esters, that probably corresponds as constituent of essential oil of fenugreek. In addition we found number of carbohydrates and complex phenolic carboxylic acids, flavonoid compounds, trihonellin alkaloids, which have a high antioxidant potential. It is recommended the using of fenugreek leaf as effective source of antioxidants in production of the flour confectionery products, particularly of crackers and puffy cookies.

\section{References}

1. Srinivasan K. (2005), Role of spices beyond food flavouring: nutraceuticals with multiple health effects, Food Reviews International, 21, pp. 167-188.

2. Hossain M.B., Brunton N.P., Barry-Ryan C., Martin-Diana A.B., Wilkinson M. (2008), Antioxidant activity of spice extracts and phenolics comparison to synthetic antioxidants, Rasayan J. Chem., 1, pp. 751-756.

3. Korableva O.A., Rakhmetov D.B. (2012), Poleznye rasteniia $v$ Ukraine: ot introduktsii do ispolzovaniia: monografiia, Fitosotsiotsentr, Kyiv.

4. Korablyova O. (2001), Alternative aromatic plants in Ukraine: cultivation and utilization, Proceedings of the 50 Anniversary Conference "Crop science on the verge of the 21 century - opportunities and challenges», Prague, Czech Republic, pp. 126127.

5. Oseiko M., Ukrainets A., Shtepa S. (2005), Likarska roslynna syrovyna, zhurnal "Kharchova i pererobna promyslovist», 7, pp. 15-17.

6. Koche D., Shirsat R., Imran S., Bhadange D.G. (2010), Phytochemical screening of eight traditionally used etnomedicinal plants from akola district (MS) India, International Journal of Pharma and Bio Sciences, 1(4), pp. 253-256.

7. Burt S.A. (2004), Essential oils: their antibacterial properties and potential applications in foods: a revive, Intern. J. Food Microbiol, 94, pp. 223-253.

8. Rakhmetov D.B., Stadnichuk N.O., Korabljova O.A. (2004), Novi kormovi, prjanosmakovi ta ovochevi introducenty $v$ Lisostepu i Polissi Ukrajiny, Fitosociocentr, Kyiv.

9. Wan-Li X. (2007), Effect of Trigonella foenum-graecum (fenugreek) extract on blood glucose, blood lipid and hemorheological properties in streptozotocin-induced diabetic rats, Asia Pacific Journal of Clinical Nutrition, 16, pp. 422-426.

10. Omezzine F., Bouaziz M., Daami-Remadi M., Simmonds M.S., Haouala R. (2014), Chemical composition and antifungal activity of Trigonella foenum-graecum L. varied with plant ploidy level and developmental stage, Arabian Journal of Chemistry, pp. 111. 
11. Sumayya A.R., Srinivasan S., Amatullah N. (2012), Screening and Biochemical Quantification of Phytochemicals in Fenugreek (Trigonella foenum-graecum), Research Journal of Pharmacentical, Biological and Chemical Sciences, 3(1), pp. 165169.

12. Renuka C. (2009), Evaluation of the antidiabetic effect of Trigonella foenum-graecum seed powder on alloxaninduced diabetic albino rats, International Journal of Pharmaceutical and Technical Research, 1, pp. 1580-1584.

13. Kumaravel S., Muthukumaran P., Shanmugapriya K. (2017), Chemical composition of Trigonella foenum- graecum through gas chromatography mass spectrometry analysis, Journal of Medicinal Plants Studies, 5(3), pp. 1-3.

14. Landge D. (2005), From sauce to shelf an introduction to the supply chain of medicinal and aromatic plants, Abstract of XYII International Botanical Congress, Vienna, pp. $105-106$.

15. Pakhomova I. V. (2016), Antyoksydanty roslynoho pokhodzhennia dlia zhyrovmisnykh kondyterskykh vyrobiv, Naukovi pratsi NUKhT, 22(11), s. 185-190.

16. Moliner-Martinez Y., Campins-Falco P., Herraier - Hernoinder R. (2004), A method for the determination of dimethylamine in air by collection on solid support sorbent with subsequent derivatization and spectrophotometric analysis, J.Chromatogr.A., 1059, pp. 17-24. 


\title{
Changes in cholesterol and free fatty acid content of Kars Gravyer Cheese (A Turkish dairy product produced by the traditional method)
}

\author{
Asya Çetinkaya', Fatih Öz ${ }^{2}$ \\ 1 - Kafkas University, Kars, Turkey \\ 2 - Ataturk University, Erzurum, Turkey
}

Keywords:

Gravyer

Cheese

Ripening

Fatty acid

Cholesterol

\section{Article history:}

Received

19.08.2018

Received in

revised form

12.09.2018

Accepted

28.09.2018

Corresponding author:

Asya Çetinkaya

E-mail:

a_cetinkaya36@

hotmail.com

DOI:

$10.24263 / 2304-$

974X-2018-7-3-6

\section{Abstract}

Introduction. This study was carried out to determine changing in the ratio of free fatty acids and cholesterol depended on the maturation period of Kars Graiver cheese produced in the traditional way, and the affect of the duration of maturation on the fatty acids composition and cholesterol levels.

Materials and methods. The fat content of the cheese samples was determined by Gerber's method. Flame Ionization DetectorGas Chromatography (GC/FID) was used to determine the fatty acids composition and cholesterol content.

Results and discussion. It was found the fat content of Kars Gravyer Cheese samples was between 27.0-38.50\%. The cholesterol content in the cheese samples ranged from 45.70 to $55.80 \mathrm{mg} / 100 \mathrm{~g}$ during 90 days of maturation. In Kars Gravyer Cheese samples, 16 saturated and unsaturated fatty acids were identified. In Gravyer Cheese samples, the content of volatile fatty acids (Butyric acid and myristic acid ) increase up to 25th day $(\mathrm{P}<0.01)$ and decrease from 45 th day to 90 th day. While levels of free fatty acids (palmitic acid and linoleic acid) generally decrease to 25 th day, they begin increasing again until the end of the maturation period. In the 90 days period of storage of Kars Gravyer Cheese, palmitic, oleic, myristic and stearic acids were found to constitute $74.29 \%$ of the total free fatty acids content. In the samples studied, the most abundant saturated fatty acids were identified as palmitic and stearic acids. Oleic acid was found to be the most abundant unsaturated fatty acid. In cheese samples, the content of monounsaturated fatty acids (MUFA) and polyunsaturated fatty acids (PUFA) ranged $28.38-32.37 \%$ and $1.59-1.84 \%$, respectively. In Kars Gravyer Cheese sample, the Atherogenicity (AI) index was defined as 2.57-3.04.

Conclusion. Fatty acids are precursors of aroma compounds like short and medium chain free fatty acids, ethyl ketones, esters and thioesters, formed in cheese in a result of various biochemical processes. The detection of large amounts of fatty acids with short and medium chains in Gravyer Cheese samples providing aroma, indicate that this cheese is flavorful cheese. 


\section{Introduction}

Today there are about 4000 different varieties of cheese in the world with different aroma and textural properties [1]. The most important factors affecting cheese quality are flavor and aroma of cheese, texture, and appearance. Unique characteristic properties of cheese are formed by biochemical reactions such as glycolysis, proteolysis, and lipolysis occurring during maturation. Free fatty acid (FFA), which emerges as a result of lipolysis reaction, is effective on the flavor and aroma of cheese. FFA is an important, volatile precursor of catabolic reactions, producing compounds that contribute to aroma [2]. The presence of short, medium and long-chain fatty acids is considered the most important indicator of cheese maturation after the compounds formed by glycolytic and proteolytic reactions [3].

The amount of free fatty acids in dairy products has potential effects not only on the taste and texture of dairy products but also on nutrition and health as antimicrobial agents. Determination of fatty acid profile of cheese is also important in terms of these negativities [4]. Cheese, which is an important source of fat in human nutrition, contains a high level of various fatty acids. From a nutritional point of view, different types of cheese contain a high level of digestible fat. Its digestibility is in the range of 88-94\% [5]. However, cheese is usually presented with a negative nutritional image due to the relationship between saturated fatty acids (SFA), the main fatty acids of cheese, and cholesterol, leading to cardiovascular diseases. Although many researchers view SFA as one of the contributing factors in heart disease, there has been no direct link between cardiovascular disease and milk fat, or a real study indicating dairy products' role in heart disease [6]. Cheese is a rich source of some trans-fatty acids and short-chain fatty acids that can be considered as part of a healthy diet [7]. The World Health Organization and the American Heart association have advised that consumers limit their intake of saturated fatty acids and cholesterol to prevent coronary heart disease. The reduction of cholesterol level in dairy products will be an attractive alternative to satisfy consumer's concerns and demands [8]. Gravyer cheese is one of the few European-style cheese that has economic value and is appreciated by consumers like domestic cheese varieties in Turkey [9]. Gravyer Cheese, one of the 18 varieties of cheese that is economically important in the world, is in the same group as Emmental (Switzerland), Gruyere (France), Fontina (Italy), Samso (Denmark), Gouda and Edam (Netherlands) [10]. Approximately 90\% (544 tons) of the production of Gravyer, which is mostly produced in the Eastern Anatolia Region especially in Kars Province and its surroundings, is carried out in Kars [11]. The industrial production of Kars Grayver Cheese is quite low. Production is mostly carried out by traditional methods in dairy farms [12]. Gravyer Cheese is produced in and around Kars Province and takes the first place after kashar, tulum and white cheese production. It has economic value for the people of the region and Kars Gravyer Cheese has brand awareness throughout the country [9].

Although there are many studies on the fatty acid composition and cholesterol content of various cheeses, no studies have been conducted on the determination of changes in cholesterol and fatty acid content during the production and maturation of Kars Gravyer Cheese. However, there are few studies in which the chemical and microbiological properties of Kars Gravyer Cheese, bought from a point of purchase, are revealed [9,13]. Therefore, the aim of this study is to determine the fatty acid composition and cholesterol level of Kars Gravyer Cheese, which will be produced by traditional methods in dairy conditions, and to determine the effect of different maturation periods on fatty acid composition and cholesterol level. 


\section{Materials and methods}

\section{Sample preparation}

Gravyer cheese was produced in a dairy farm in central Boğatepe village of Kars Province according to the flow diagram given in Figure 1. Gravyer cheese production was done in two repetitions. Samples were taken on different maturation days (0th,10th, 25th, 45th, 60th and 90th days) from the produced cheeses and brought to the laboratories under cold chain conditions and fat content, fatty acid composition and cholesterol analyses were performed.

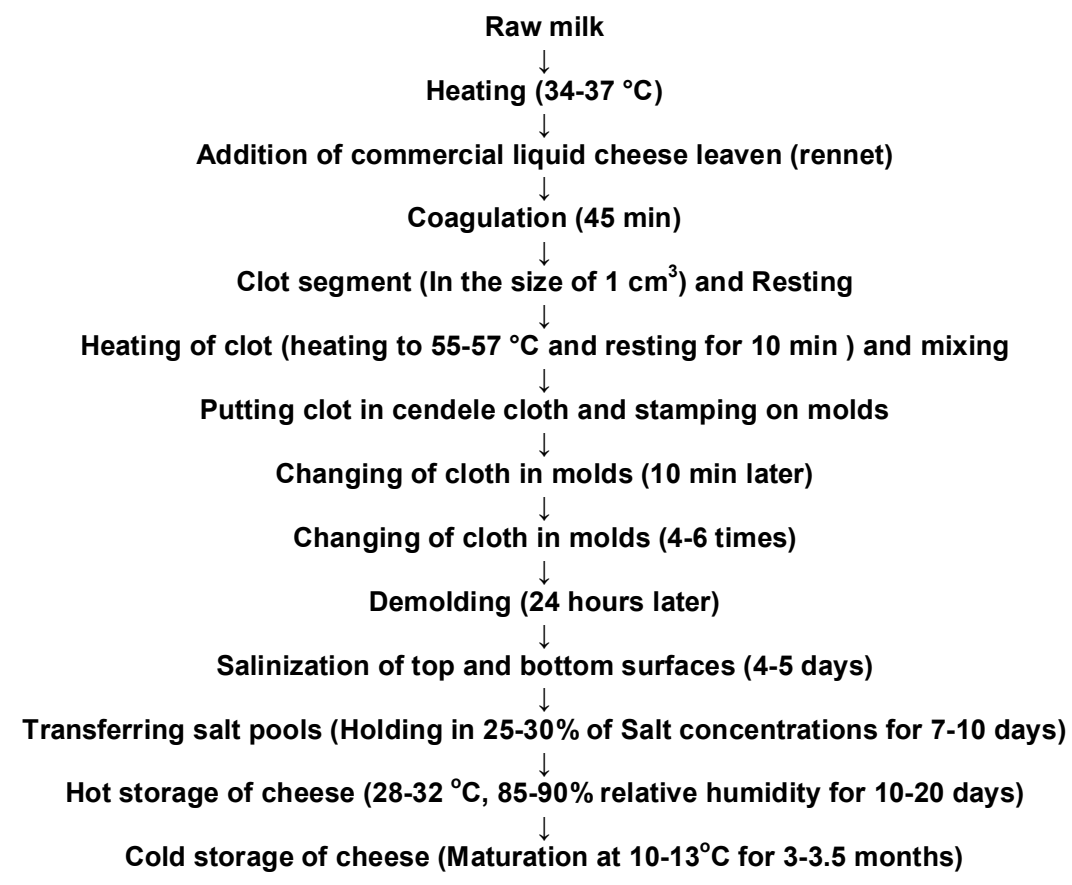

Figure 1. Production flowchart of Gravyer cheese

\section{Methods}

\section{Determination of fat}

The fat content of the samples was determined using Gerber method [14].

\section{Determination of fatty acid composition}

The fatty acid composition of the samples was determined according to the fatty acid methyl ester method (FAME) (AOAC 1996.01) [15]. Approximately $0.1 \mathrm{~g}$ of fat obtained as a result of fat determination method was mixed and shaken with $10 \mathrm{ml}$ of $\mathrm{n}$-hexane and mixed again with a $0.5 \mathrm{ml} 2 \mathrm{~N}$ potassium hydroxide solution with methanol. After standing for 1-2 hours in the dark, $1 \mu \mathrm{l}$ of the supernatant was taken and directly injected into the gas chromatograph. 


\section{- Food Technology -}

\section{GC Conditions for the analysis of fatty Acid composition}

For the fats, the FAME composition was analyzed using a Restek RTX-2330 capillary column (60 m, $0.25 \mathrm{~mm}$ id, $0.1 \mu \mathrm{m}$ film thickness, Bellefonte, PA, USA) in Shimadzu brand gas chromatography (model QP2010 Plus) and a flame ionization detector. The device was given $1 \mu \mathrm{l}$ as the injection volume from the sample. The column furnace temperature was programmed to reach $240{ }^{\circ} \mathrm{C}$ with an increase of $4{ }^{\circ} \mathrm{C} / \mathrm{min}$ after kept for 3 minutes at $100{ }^{\circ} \mathrm{C}$ and to wait 18 minutes at the last temperature value. The injection temperature was set at $250{ }^{\circ} \mathrm{C}$ and the detector temperature was set at $255^{\circ} \mathrm{C}$. Helium was used as a carrier gas. Injection split ratio was used at 1:80 ratio. For the control of the GC/FID system, the LabSolution computer program and FAME Mix standard (37 components) (Restek) were used. FAME peaks were identified by comparing the chain lengths and retention times of the fatty acids specified in the FAME standard.

\section{Determination of cholesterol level}

Cholesterol analysis of samples was done according to [16] with some modifications. According to the method, $1 \mathrm{ml}$ of internal standard (stigmasterol, $0.5 \mathrm{mg} / \mathrm{ml}$ ) and $0.5 \mathrm{ml}$ of $2 \mathrm{~N}$ alcoholic potassium hydroxide solution were added to $0.5 \mathrm{~g}$ of fat and the mixture is left to stand in a water bath at $80{ }^{\circ} \mathrm{C}$ for 15 minutes. Then, after cooling to room temperature, $1 \mathrm{ml}$ of distilled water and $5 \mathrm{ml}$ of $\mathrm{n}$-hexane were added to it and shaken for 1 min. it was then centrifuged at $2000 \mathrm{~g}$ for $1 \mathrm{~min}$ and $1 \mathrm{~mL}$ of the supernatant was removed and injected directly into the gas chromatography device.

\section{GC Conditions for cholesterol analysis}

Cholesterol analysis of samples was performed on a Shimadzu brand gas chromatography (model QP2010 plus) device using Restek Rtx-65TG (30 m x 0.32 mm ID, film thickness $0.1 \mu \mathrm{m}$ ) (Restek international, Bellefonte, PA, USA) silica column (65\% diphenyl-35\% dimethyl-polysiloxane) and flame ionization detector (FID). The column oven temperature was raised to $150{ }^{\circ} \mathrm{C}$ with an increase of $30{ }^{\circ} \mathrm{C} / \mathrm{min}$ and then to $360{ }^{\circ} \mathrm{C}$ with an increase of $15{ }^{\circ} \mathrm{C} / \mathrm{min}$ and kept at this temperature for 3 minutes. Injection port temperature was set at $300{ }^{\circ} \mathrm{C}$ and detector temperature was set at $370{ }^{\circ} \mathrm{C}$, helium was used as the carrier gas. The injection split ratio was used at 1:25.

\section{Lipid quality index}

Unsaturated/saturated fatty acids (USFA / SFA) ratios and desired fatty acids (DFA) were calculated from the fatty acid profiles of the cheeses.

In addition, in order to correlate the fatty acids profile with the risk of cardiovascular disease, the atherogenicity indices (AI) were calculated according to the following equation suggested by the equation by [17].

AI, shows the relationship between the sum of the main saturated FAs and the main classes of unsaturated FAs. The former is considered as proatherogenic (favouring the adhesion of lipids to cells of the immunological and circulatory system), and the latter as anti-atherogenic (inhibiting the aggregation of plaque and diminishing the levels of esterified fatty acid, cholesterol, and phospholipids, thereby preventing the appearance of micro-and macrocoronary diseases) [18]. 


\section{Statistical analysis}

In the evaluation of the obtained results, mean values and standard errors of the samples were determined using SPSS package program, and differences in the fatty acid composition and cholesterol level between fresh and mature Gravyer Cheese samples were analyzed by t-test.

\section{Results and discussions}

Fat ratios of Kars Gravyer Cheese samples are given in Table 1 and cholesterol ratios in Table 2.

Table 1

Fat proportion of Kars Gravyer Cheese during ripening $\left(\bar{X}_{ \pm} S_{x}\right)$

\begin{tabular}{|c|c|c|c|c|c|c|c|c|}
\hline \multirow{2}{*}{ Parameter (\%) } & \multicolumn{8}{|c|}{ Ripening Period (Day) } \\
\cline { 2 - 9 } & 0 & 10 & 25 & 45 & $\mathbf{6 0}$ & 90 & F value & $\mathrm{P}$ \\
\hline \multirow{2}{*}{ Fat } & 27.0 & 28.0 & 29.5 & 33 & 35.57 & 38.5 & 789.97 & $* * *$ \\
& $\pm 0.00 \mathrm{a}$ & $\pm 0.51 \mathrm{~b}$ & $\pm 0.70 \mathrm{c}$ & $\pm 0.71 \mathrm{~d}$ & $\pm 0.72 \mathrm{e}$ & $\pm 0.71 \mathrm{f}$ & & \\
\hline
\end{tabular}

Results are expressed as mean \pm standard deviation of means

$* * *$ a,b,c,d,e,f, $:$ Different letters in the same line refers significant differences between the averages $(P<$ $0.001)$

Cholesterol level of Kars Gravyer Cheese during ripening ( $\mathrm{mg} / \mathbf{1 0 0 g})$

Table 2

\begin{tabular}{|c|c|c|c|c|c|}
\hline \multicolumn{7}{|c|}{ Ripening period (Day) } \\
\hline $\mathbf{0}$ & $\mathbf{1 0}$ & $\mathbf{2 5}$ & $\mathbf{4 5}$ & $\mathbf{6 0}$ & $\mathbf{9 0}$ \\
\hline 45.70 & 48.54 & 58.36 & 155.80 & 104.72 & 101.52 \\
\pm 3.18 & \pm 6.32 & \pm 9.27 & \pm 6.32 & \pm 16.51 & \pm 0.89 \\
\hline
\end{tabular}

Depending on the type of cheese, ripening time varies from a few weeks to three years. The cholesterol ratio of cheese samples ranged from 45.70 to $155.80 \mathrm{mg} / 100 \mathrm{~g}$ during 90 days of maturation. Health lipid indices and the ratio double-carbon saturated of and unsaturated fatty acids in Kars Gravyer Cheese samples is given in Table 3-5.

Table 3

Health lipid indices of Kars Gravyer cheese (mg /100 g)

\begin{tabular}{|c|c|c|c|c|c|c|c|}
\hline & \multicolumn{6}{|c|}{ Kars Gravyer cheese* } & \\
\hline Fatty Acids & $\mathbf{0}$ & 10 & 25 & 45 & 60 & 90 & Total \\
\hline Satured fatty acid & 98.22 & 98.45 & 98.56 & 98.44 & 98.36 & 98.49 & 410.93 \\
\hline SCSFA C4:0-C8:0 & 5.35 & 6.12 & 6.15 & 5.90 & 5.63 & 4.84 & 33.99 \\
\hline MCFA C10:0-C14:0 & 17.34 & 19.47 & 19.24 & 18.48 & 17.59 & 15.95 & 108.07 \\
\hline LCSFAC 16:0-C18:2 & 75.53 & 72.86 & 73.17 & 74.06 & 75.14 & 77.70 & 448.46 \\
\hline MUFA & 30.15 & 28.38 & 28.59 & 29.97 & 32.37 & 31.30 & 180.76 \\
\hline PUFA & 1.84 & 1.84 & 1.84 & 1.76 & 1.80 & 1.59 & 10.64 \\
\hline DFA & 45.52 & 43.46 & 44.16 & 45.31 & 47.98 & 48.05 & 274.48 \\
\hline $\mathrm{AI}$ & 2.79 & 3.04 & 3.01 & 2.83 & 2.57 & 2.71 & 16.95 \\
\hline USFA/SFA & 0.47 & 0.43 & 0.44 & 0.46 & 0.49 & 0.46 & 2.75 \\
\hline
\end{tabular}

*Data were presented as average values; AI - atherogenicity index; 


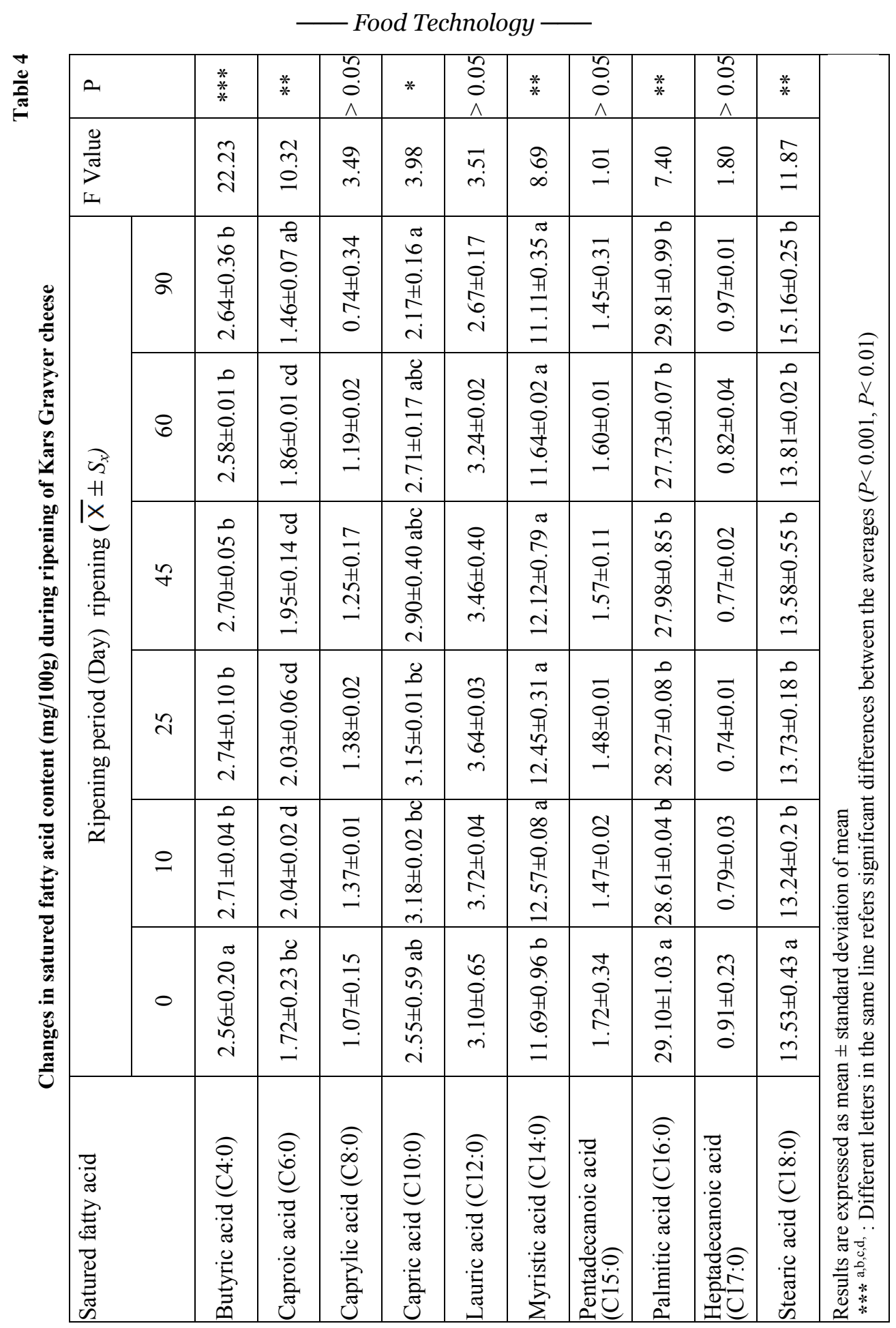


— Food Technology —

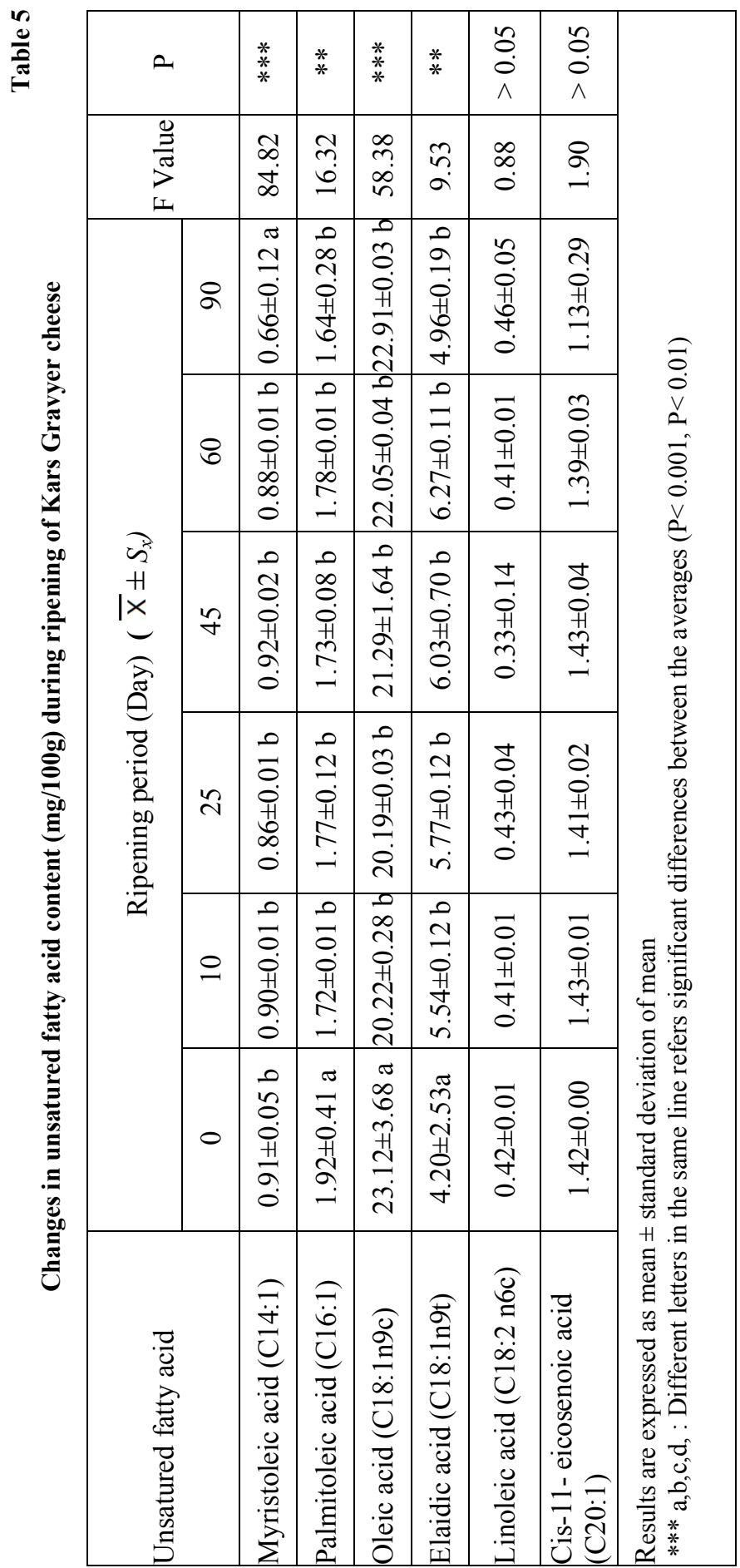


Cheese ripening is a slow and complex biochemical process that is costly due to the long storage period. The formation of biochemical and physical reactions during ripening plays an important role in the texture and taste of matured cheese [19]. The cholesterol ratio of cheese samples increased until the 45th day, decreased by 60th and 90th day. The average amount of cholesterol in cheese samples was found as $85.77 \mathrm{mg} / 100 \mathrm{~g}$. The value found is higher than the value found in Kars Gravyer Cheese $(54.23 \mathrm{mg} / 100)$ by Karagözlü et al. [20] between the values (44.6-147.769 mg/100) found in some local Turkish by Dönmez et al. [21] and close to values $(82.52 \mathrm{mg} / 100 \mathrm{~g})$ in Gouda cheese by Ho-Jung et al. [8].

As a result of the literature review, no research was found related to the determination of fatty acids profile in the production and storage stages of Kars Gravyer Cheese. For this reason, the results obtained from this research will be interpreted taking into consideration the studies conducted in other cheese varieties. Table 4 and 5 show that the fatty acid ratios of the Kars Gravyer Cheese samples changed during the maturation period from the production stage. This may be due to biochemical processes occurring in different maturity periods of the cheeses. Double carbon saturated and unsaturated 16 fatty acids were identified in Kars Gravyer Cheese samples. According to the results of the analysis, the highest fatty acids in the cheese samples were palmitic, oleic, stearic and myristic fatty acids. Ratios of butyric (C4: 0), caproic (C6:0), caprylic (C8:0), capric (C10:0), lauric (C12:0), myristic (C14:0), pentadekanoic (C15:0), palmitic (C16:0), heptadecanoic (C17:0), stearic (C18:0), myristoleic acid (C14:1), palmitoleic (C16:1), oleic (C18:1), elaidic (C18:1 (trans 9), linoleic (C18: 2) and 11 -eicosenoic (C20: 1) acid identified in cheese samples ranged between $2.56-2.74 \mathrm{mg} / 100 \mathrm{~g}, 1.46-2.04 \mathrm{mg} / 100 \mathrm{~g}, 0.74-1.38 \mathrm{mg} / 100 \mathrm{~g}, 2.17-3.18$ $\mathrm{mg} / 100 \mathrm{~g}, 2.67-3.72 \mathrm{mg} / 100 \mathrm{~g}, 11.11-12.57 \mathrm{mg} / 100 \mathrm{~g}, 1.45-1.72 \mathrm{mg} / 100 \mathrm{~g}, 27.73-29.81$ $\mathrm{mg} / 100 \mathrm{~g}, \quad 0.74-0.97 \mathrm{mg} / 100 \mathrm{~g}, \quad 13.24-15.16 \mathrm{mg} / 100 \mathrm{~g}, \quad 0.66-0.92 \mathrm{mg} / 100 \mathrm{~g}, \quad 1.64$ $1.92 \mathrm{mg} / 100 \mathrm{~g}, 20.19-23.12 \mathrm{mg} 100 \mathrm{~g}, 4.20-6.27 \mathrm{mg} / 100 \mathrm{~g}, 0.33-0.46 \mathrm{mg} / 100 \mathrm{~g}$ and $1.13-$ $1.43 \mathrm{mg} / 100 \mathrm{~g}$ respectively.

Changes in the total free fatty acids C4, C6, C10, C14, C16, C18, C14:1, C16:1, $\mathrm{C} 18: 1 \mathrm{~N} 9 \mathrm{~T}$ and $\mathrm{C} 18: 1 \mathrm{n} 9 \mathrm{C}$ values of all cheese samples during the ripening period were statistically significant $(P<0.001, P<0.01, P<0.05)$ and the changes in $\mathrm{C} 8, \mathrm{C} 12, \mathrm{C} 17$, $\mathrm{C} 18: 2$ and $\mathrm{C} 20: \ln 9$ values were statistically insignificant $(P>0.05)$.

Abd El-Salam [22] reported that milk varieties, maturation temperature, salt concentration, milk lipase, starter bacteria and other microbial lipases were also effective on the formation of free fatty acids in cheese such as Feta and Teleme. Free fatty acids are primarily formed by the enzymatic breakdown of glycerides in dairy products [23]. Free fatty acids, as they directly contribute to the flavor of the cheese, also play a role in many types of reactions leading to the formation of methyl ketones, secondary alcohols, aliphatic and aromatic esters [24]. The free volatile fatty acids found in cheeses are closely related to flavor and aroma, and acetic, butyric, caproic, caprylic and capric acids are the most important free fatty acids affecting the cheese flavor [24].

In Kars Gravyer Cheese samples, the amount of volatile fatty acids (C4: 0-C14: 0 ) increased up to 25 th day $(P<0.01)$ and decreased from 45 th day to 90 th day. While levels of free fatty acids (C16: 0-C18: 2) generally decrease at day 25, they have begun to increase again until the end of the ripening period. Kara et al. [25] stated that the proportion of fatty acids in tulum cheese increased until the 30th day and then decreased until the 90th day. In the studies carried out by different researchers [26-28]. the level of volatile fatty acids has been reported to rise during maturation. Unlike other studies, free fatty acids increased up to the 25th day and then decreased periodically (45-90 days). The reason for the decline in free fatty acids between 45 and 90 days is that some of the free fatty acids that occur at the 
end of maturation are converted into $\beta$-oxidation and methyl ketones, carbonyl compounds and other decomposition products [29].

Short and mid-chain saturated free fatty acids such as butyric, caproic, caprylic and capric acid are often the result of lipolysis of triglycerides by molds. However, in some cases, fatty acids containing up to six carbon atoms can be formed by the reduction of lactose and amino acids or the oxidation of ketones, aldehydes, and esters ([30]. Short and medium chain fatty acids have a low sensory perception threshold and have a more significant effect on the flavor development of cheese than long chain fatty acids.

In this study, the average values of butyric, caproic, caprylic and capricic acid during 90 days maturation period in Kars Gravyer cheese were found as $2.56-2.74 \mathrm{mg} / 100 \mathrm{~g}, 1.72-$ $2.04 \mathrm{mg} / 100 \mathrm{~g}, 1.07-1.38 \mathrm{mg} / 100 \mathrm{~g}$ and $2.55-3.18 \mathrm{mg} / 100 \mathrm{~g}$ respectively. The values obtained are higher than the values found by Türkoğlu, [27], in braided cheese and by Atasoy et al. [26], in Urfa cheese and lower than the values found in Van Otlu Cheese by Ocak et al. [31], and the values found in 11 different cheese varieties by Hayaloğlu et al. [32], Palmitic, oleic, myristic and stearic acid formed in gravyer cheese during maturation accounted for $74.29 \%$ of the total free fatty acids content. The most abundant fatty acids in fresh and ripe gravyer cheeses are palmitic acid (C16:0). This ratio varied between 27.73$29.81 \mathrm{mg} / 100 \mathrm{~g}$. Other acids following this fatty acid are oleic (C18:1) (20.19-23.12 $\mathrm{mg} / 100 \mathrm{~g})$ stearic acid (C18:0) (13.24-15.16) and myristic acid (C14:0) (11.11-12.57) respectively. This may be due to the presence of large amounts of palmitic, oleic, stearic and myristic fatty acids in milk fat [33]. The values identified in gravyer cheese are higher than the values obtained by Atasoy et al. [26], in Urfa cheese (myristic acid 6.37-12.40 $\mathrm{mg} / 100 \mathrm{~g}$, palmitic acid $18.0-26.9 \mathrm{mg} / 100 \mathrm{~g}$ and oleic acid $12.7-19.00 \mathrm{mg} / 100 \mathrm{~g}$ ) and lower than the values found in 11 different cheese varieties (myristic acid $6.2-139.7 \mathrm{mg} / 100 \mathrm{~g}$, palmitic acid $19.9-356.7 \mathrm{mg} / 100 \mathrm{~g}$ and $17.6-386.3 \mathrm{mg} / 100 \mathrm{~g}$ ) by Hayaloğlu et al. [32], Mallatou et al. [34], reported that although palmitic, stearic and oleic fatty acids form dominant fatty acids in feta cheese, these fatty acids were not as effective as short-chain fatty acids on cheese flavor. Lauric acid (C12:0) is the predominant fatty acid (2.67-3.72 $\mathrm{mg} / 100 \mathrm{~g}$ ) among short and medium-chain fatty acids. Aminifar et al. [35], Marrone et al. [36], and Ocak, et al. [31]. Şengül et al. [3], and Arslaner et al. [28], reported that palmitic, myristic, stearic and oleic fatty acids had the highest proportion among the fatty acids in Lighvan cheese, in Pecorino Carmastiano cheese, in fresh and ripe Herbed cheeses, in Karın kaymağ 1 cheese samples and in Tulum cheese respectively. In addition, Ocak et al. [31], stated that lauric acid (C12:0) was the predominant fatty acid among short and medium-chain fatty acids. The amounts of oleic and especially linoleic acid, which are very important in terms of nutrition physiology and which cause certain dermatological diseases and increase in the water permeability of cells in their deficiency or absence in the diet are determined as $20.19-23.12 \mathrm{mg} / 100 \mathrm{~g}$ and $0.33-0.46 \mathrm{mg} / 100 \mathrm{~g}$ respectively.

Elaidic acid (C18:1) acid level increased up to 60 days during maturation but decreased for 90 days. The contents of linoleic acid (C18: 2) $(0.33-0.46 \mathrm{mg} / 100 \mathrm{~g})$ and cis-11eicosenoic acid (C20:1) (1.13-1.43 mg/100g) of fresh and ripe Gravyer cheeses were found to vary within a narrow range. Cheese fat contains saturated (SFA), monounsaturated (MUFA) and polyunsaturated (PUFA) fatty acids. Milk fat generally contains approximately $66 \%$ saturated (SFA) $(57.4 \%$ palmitic, $21.6 \%$ myristic and $17.6 \%$ stearic), $30 \%$ monounsaturated (MUFA) and $4 \%$ polyunsaturated fatty acids (PUFA) (LópezExpósito, Amigo, \& Recio, 2012). Of the fatty acids identified in the cheese samples, $68.22 \%$ were saturated fatty acids and $31.77 \%$ were unsaturated fatty acids. Dönmezet al. [21], determined saturated fatty acid ratio as $60.80-76.57 \%$. Short, medium and long chain fatty acids were determined as $4.84-6.15 \%, 15.95-19.47 \%$ and $71.43-76.57 \%$ in Kars 
Gravyer Cheese samples, respectively. According to values determined in Gravyer Cheese: Atasoy et al. [26], in Urfa cheese $(7-8 \%, 20-23 \%$ and $70-72 \%)$ and Sert et al. [38], found in tulum cheese $(15.08-22.51 \%, 39.13-42.62 \%$ and $30.92-38.56 \%)$, Turkoglu [27], found in braided cheese (medium and long chain fatty acids $24-27 \%$ and $63-72 \%$ ) that short chain (SCSFA) and medium-chain (MCSFA) fatty acids were low and low-chain fatty acids (LCSFA) were high in concentration. In cheese samples, the proportions of monounsaturated fatty acid (MUFA) and polyunsaturated fatty acid (PUFA) were found to be $28.38-32.37 \%$ and $1.59-1.84 \%$, respectively Dönmez et al. [21], found in some traditional Turkish cheeses, that MUFA was $21.42-34.05 \%$ and PUFA $1.47-3.59 \%$ and Kinık et al. [39]. In 29 different hard and soft cheese varieties, MUFA was determined as 24.14-27.63 and PUFA as $0.72-1.58 \%$. The values found in Gravyer cheese were higher than found by Kınık, et al. [39], approximately around the same MUFA value range found by Dönmez et al. [21], and lower than the PUFA values of the same study.

The Atherogenicity (AI) index, desired fatty acids (DFA) and ASFA / SFA ratios were determined as 2.57-3.04, 43.46-48.05 and 0.43-0.49 in Kars Gravyer Cheese samples, respectively. The values found were higher than the AI value determined in traditional Serbian white cheese (1.89-3.06) by Barac et al. [5], in Serbian traditional white cheeses, higher than the lower limit of DFA (34.45-46.34), lower than the upper limit, and higher than USFA/SFA $(0.30-0.51)$.

\section{Conclusion}

This study was the first to examine the changes in free fatty acids and cholesterol levels and examine the effect of ripening days on the change of fatty acid composition and cholesterol level during maturation starting from production. In the 90 day storage period of Kars Gravyer Cheese, palmitic, oleic, myristic and stearic acid constituted $74.29 \%$ of the total free fatty acids content and while the most abundant saturated fatty acids were palmitic and stearic acid, oleic acid was the most abundant unsaturated fatty acid. The cholesterol content of cheese samples ranged from 45.70 to $55.80 \mathrm{mg} / 100 \mathrm{~g}$ during 90 days of maturation. In this study, the distribution of saturated and unsaturated fatty acids in milk fat, which is very important in terms of human nutrition, was determined in Kars Gravyer Cheese. In cheese samples, 10 saturated fatty acids and 6 unsaturated fatty acids were determined and medium and long-chain fatty acid ratios were found to be higher than short chain fatty acids. Conversion of triglycerides into free fatty acids by microorganisms and natural milk lipase plays an important role in the development of different aroma substances in ripe cheeses. Especially short and medium chain free fatty acids are used as precursors in the formation of aromatic products such as ethyl ketones, esters and thioesters $[31,40]$. It can be said that Kars Gravyer Cheese is a very aromatic cheese because it contains short and medium chain fatty acids which have an important effect on the flavor and aroma of milk and dairy products. Having said that, this research is also important in terms of shedding light on the research to be carried out in the future.

Acknowledgements

Authors wish to thank the Research Fund of Kafkas University (No. 2017-FM-02) for the financial support. 


\section{References}

1. Üçüncü M. (2004), A'dan Z’ye Peynir Teknolojisi, Ege Üniversitesi Mühendislik Fakültesi, Gıda Müh. Bölümü. Cilt 1. Bornova/ İzmir.

2. McSweeney P.L.H., Sousa M.J. (2000), Biochemical pathways for the production of flavour compounds in cheeses during ripening. A review, Lait, 80, pp. 293-324.

3. Şengül M., Erkaya E., Ceyhun A.E.(2011), Fatty acid composition of Karın Kaymağı cheese, Journal of the Faculty of Agriculture, 42(1), pp. 57-62.

4. Kilcawley K.N., Mannion D.T. (2017), Free Fatty Acids Quantification In Dairy Products, World's largest Science, Technology \& Medicine Open Access book Publisher, pp. 209-220.

5. Barać M., Kresojević M., Špirović-Trifunović B., Pešić M., Vučić T., Kostić A. Despotović S. (2018), Fatty acid profiles and mineral content of Serbian traditional white brined cheeses, Mljekarstvo, 68(1), pp. 37-45

6. Kanekanian A. (2014), The health benefits of bioactive compounds from milk and dairy products, In: Milk and Dairy Products as Functional Foods, ed A. Kanekanian, John Wiley \& Sons, Ltd, Oxford, pp. 1-22.

7. Lock A.L., Givens D.I., Bauman D.E., (2014), Dairy fat: Perceptions and realities. In: Milk and Dairy Products as Functional Foods, Ed. A. Kanekanian, John Wiley \& Sons, Ltd, Oxford, pp. 174-192.

8. Ho-Jung J., Eun-Jung K., Hae-Soo K.(2013), Comparison of physicochemical and sensory properties between cholesterol-removed Gouda cheese and Gouda cheese during ripening, Asian Australasian Association of Animal Science, 26(12), pp. 1773-1780.

9. Ulutaş Z., Çağlar A., Kurt A. (1993), Kars Gravyer peynirinin yapıllışı, duyusal fiziksel ve kimyasal özellikleri üzerinde bir araştırma, Glda, 18 (3), pp. 197-202. (In Turkish).

10. Adam R.C. (1956), Türkiye Süt ve Mamullerinin Bileşimi, Ankara Üniversitesi, 92, Ankara.

11. Anon (2015), Kars 2015 yll süt ve ürünleri kapasite raporu. Kars Sanayi ve Ticaret Odası Müdürlü̈̆̈̈, Kars/Turkiye (In Turkish)

12. Anon (2007), Düzey II bölgeleri kalkınma programı, pazarlama araştırmalarl, süt ve süt ürünleri- TRA2, RD-AKKM.419.TR.

13. Topuk Ş., Sezer Ç. (2015), Some quality characterıstıcs of Kars Gravyer cheese, The Journal of Food, 40(2), pp. 69-75.

14. Turkish Standards (1978), (Van Gulik Methods) Official methods of analysis, Turkish Standards Institution, Ankara.

15. Satchithanandam S., Fritsche J., Rader J.I. (2001), Extension of AOAC Official Method 996.01 to the Analysis of Standard Reference Material (SRM) 1846 and Infant Formula, Journal of AOAC Int,. 84, pp. 805.

16. Fletouris D.J., Botsoglou N.A., Psomas I.E., Mant1s A.I. (1998), Rapid determination of cholesterol In milk and milk products By direct saponification and capillary gas chromatography, Journal of Dairy Science, 81(11), pp. 2833-2840.

17. Ulbricht T.L.V., Southgate D.A.T. (1991), Coronary heart disease: seven dietary factors. The Lancet, 338(8773), pp. 985-992.

18. Prandini A., S. Sigolo, G. Piva A. (2011), Comparative study of fatty acid composition and CLA concentration in commercial cheeses, Journal of Food Composition and Analysis, 24(1), pp. 5561.

19. Tunick M. H. (2000), Rheology of dairy foods that gel, stretch and fracture, Journal of Dairy Science, 83(8), pp. 1892-1898.

20. Karagözlü C., Yerlikaya O., Akpınar A., Ünal G., Ergönül B., Ender G., H.R. Uysal H.R. (2016), Cholesterol levels and some nutritional parametres of traditional cheeses in Turkey, Ege Üniversitesi Ziraat Fakültesi Dergisi, 53(2), pp. 161-168.

21. Dönmez M., Seçkin A.K., Sağdıç O., Şimşek B. (2005), Chemical chracteristics fatty acid compositions conjugated linoleic acid contents and cholesterol levels of some tradional Turkish cheeses, International Journal of Food Sciences and Nutrition, 56 (3), pp. 157-163.

22. Abd El-Salam M.H. (1987), Domiati and Feta Type Cheeses. Cheese: Chemistry, Physics and Microbiology, Elsevier Applied Science, London. pp. 277-309. 
23. Deeth H.C. Fitz-Gerald C.H. (1995), Lipolyticenzymes and Hydrolytic Rancidity In Milk and Milk Products, In P. F. Fox (Ed.), Advanced dairy chemistry-2.Lipids, Chapman \& Hal, London.

24. Karaca O.B. (2007), Effects of using proteolytic and lipolytic enzyme from microbiolojical sources on ripening and properties of white cheese, Department of Food Engineering Institute of Naturel and Applied Sciences University of Çukurova. PhD thesis, Adana-Turkey.

25. Kara R., Bulut S., Akkaya L. (2014), Determination of fatty acid composition of Afyon Tulum cheese, Journal of Food and Nutrition Research, 28(2), pp. 17-20.

26. Atasoy A.F., Türkoğlu H. (2008), Changes of composition and free fatty acid contents of Urfa cheeses (a white-brined Turkish cheese) during ripening: Effects of heat treatments and starter cultures, Food Chemistry, 110(3), pp. 598-604

27. Türkoğlu T. (2011), Free fatty acid composition and sensory characteristics of Örgü cheese, Scientific Research and Essays, 6(7), pp. 1555-1560.

28. Arslaner A., Bakırc1 I. (2016), Effect of milk type, pasteurization and packaging materials on some physicochemical properties and free fatty acid profiles of tulum cheese, Akademik Grda, 14(29), pp. 98-104.

29. Akyüz A. (2003), Effect of some spices extracts added on lypolysis of White cheese during ripening, The Journal of Food, 28(3), pp. 295-303.

30. Molimard P., Spinnler H.E.(1996), Review: compounds involved in the flavour of surface mondripened cheeses: origins and properties, Journal of Dairy Science, 79, pp. 169-184.

31. Ocak E., Tunçtürk Y., Javıdıpour I, Köse Ş.( 2015), The changes in the Van herby cheeses made from different variety of milks during ripening: microbiological changes, lipolysis and free fatty acids, YYU J AGR SCI, 25(2), pp. 164-173.

32. Hayaloglu A.A., I. Karabulut I.(2013), Characterization and comparison of free fatty acid profiles of eleven varieties of Turkish cheeses, International Journal of Food Properties, 16(6), pp. 1407-1416.

33. Christie W.W. (1983), The Composition and Structure of Milk Lipids, In P. F. Fox (Ed.), Developments in dairy chemistry. Lipids, 2, Applied Science Publishers, London.

34. Mallatou H., Pappa E., Massouras T. (2003), Changes in free fatty acids in during ripening of Teleme cheese made with ewes, goats, cows or a mixture of ewes and goats milk, International Dairy Journal, 13(2/3), pp. 211-219.

35. Aminifar M., Emam-Djomeh Z. (2014), Changes of texture, microstructure and free fatty acid contents of lighvan cheese during accelerated ripening with lipase, J of Agri. Sci. and Techn. 16(6), pp. 113-123.

36. Marrone R., Balestrieri A., Pepe T.,Vollano L., Murru N., D’Occhio M.J, Anastasio A. (2014), Physicochemical composition, fatty acid profile and cholesterol content of "Pecorino Carmasciano" cheese, a traditional Italian dairy product, Journal of Food Composition and Analysis, 36(1-2), pp. 2-20.

37. López-Expósito I., Amigo L., Recio I. (2012), A mini-review on health and nutritional aspects of cheese with a focus on bioactive peptides, Dairy Science and Technology. 92(5), pp. 419-438.

38. Sert D., Akın N., Aktumsek A. (2014), Lipolysis in Tulum cheese produced from raw and pasteurized goats' milk during ripening, Small Ruminant Research, 121, pp. 351-360.

39. Kınık Ö., Gursoy O., Seckin A.K.(2005), Cholesterol content and fatty acid composition of most consumed Turkish hard and soft cheeses, Czech Journal Food Science, 23(4), pp. 166-172 .

40. Collins Y.F., McSweeney P.L.H., Wilkinson M.G. (2003), Lipolysis and free fatty acid catabolism in cheese: a review of current knowledge, International Dairy Journal, 13(11), pp. 841-866. 


\title{
Identification of beeswax and its falsification by the method of infrared spectroscopy
}

\author{
Volodymyr Vyshniak ${ }^{1}$, Oleg Dimitriev², \\ Svitlana Litvynchuk ${ }^{1}$, Valeriy Dombrovskiy ${ }^{3}$
}

\author{
1 - National University of Food Technologies, Kyiv, Ukraine \\ 2 - V. E. Lashkaryov Institute of Semiconductor Physics of the National academy of \\ sciences of Ukraine, Kyiv \\ 3 - Bikiper company "Kyivoblbdzholoprom", Boiarka, Ukraine
}

\section{Keywords:}

Wax

Paraffin

Ceresin

Spectroscopy

Falsification

\section{Article history:}

Received

01.07.2018

Received in revised

form 03.09.2018

Accepted 28.09.2018

\section{Corresponding}

author:

Volodymyr

Vyshniak

E-mail:

vladimir_kiev@i.ua

DOI:

10.24263/2304-

974X-2018-7-3-7

\section{Abstract}

Introduction. The purpose of the research was to determine the characteristics of the infrared spectra of reflection and absorption of beeswax, as well as wax with the content of impurities in it, in particular paraffin and ceresin.

Materials and methods. Natural beeswax, paraffin, ceresin, as well as their mixtures were investigated by infrared spectroscopy of reflection and absorption using Infrapid-61, Luminar 5030 and SPECORD M-80 spectrometers.

Results and discussion. Infrared reflection spectra from smooth surfaces of samples (paraffin, ceresin, wax, a mixture of beeswax and ceresin, a mixture of wax paraffin and ceresin, a mixture of wax and paraffin) have a similar structure. There are two clearly expressed maxima at wavelengths of 1510 and 1581 $\mathrm{nm}$. The ratio $\mathrm{R}_{\mathrm{w}}(1581) / \mathrm{R}_{\mathrm{w}}(1510)$ varies from 1.115 to 1.265 . The smallest value corresponds to natural beeswax, and the maximum value is ceresin. After shredding the sample, the infrared spectral diffuse reflections did not undergo significant changes, the most intense spectral maxima did not change its position, but the redistribution of spectral lines by intensity was happened out. There were pronounced differences in the region from 1723 to $2400 \mathrm{~nm}$. The coefficient $\alpha$ for the reflection spectra from the smooth surface was $\sim 1.2$, and for the reflection spectra from the crushed samples $\sim 1.1$. The reflection spectra in the region from 1100 to $1350 \mathrm{~nm}$ have a clear maximum at a wavelength of 1212.5 $\mathrm{nm}$.

IR reflection spectra allowed us to clarify the difference between the natural beeswax and ceresin through the ratio of reflection features at 1510 and $1581 \mathrm{~nm}$ : the maximal ratio corresponded to the former, while the smallest one to the latter. The different proportion of bands corresponding to $\mathrm{CH}_{2}$ and $\mathrm{CH}_{3}$ stretching vibrations suggested that hydrocarbon chains of wax molecules are longer than those of paraffin and ceresin studied. It was found that hydrocarbon contaminants in the bee wax are associated with narrowing of the $\mathrm{C}=\mathrm{O}$ band at $\sim 1736 \mathrm{~cm}^{-1}$.

Conclusions. The detected spectral laws will enable the identification of natural beeswax and detect its counterfeit. 


\section{- Food Technology -}

\section{Introduction}

Bee wax is widely used in many branches of the national economy [1, 2, 29], as well as in metallurgical, electrical, chemical, pharmaceutical [3-5], food industry, in particular in the production of cheese and sweets, as well as the coverage of fruits and vegetables in order to increase their shelf life $[6,30]$. However, most of the wax is returned to beekeeping for the industrial production of wax.

Waxes with impurities are called counterfeit [7-10]. It poses a serious threat to the beekeeping industry. The falsification of beeswax causes economic and image losses of the industry, worsens the productivity and quality of honey, and also significantly reduces the welfare of honey bees. The most common impurities that are added to beeswax are paraffin, ceresin, microcrystal wax, fat, stearic acid, clay, sand, hard fat, chalk, gypsum.

The high cost of beeswax compared with other waxy products (paraffin, ceresin), as well as the fact that it is quite difficult to distinguish the impurities from natural wax by external signs, making beeswax attractive for falsification [11].

According to the current requirements of quality, the industry is allowed to produce wax with insignificant content of paraffin and ceresin, but in order to improve the quality of beekeeping products and to avoid further complications, it is desirable to avoid the presence of these unnatural impurities.

Currently, there are a number of classic traditional methods for verifying the authenticity of beeswax [11] and controlling its quality: organoleptic, chemical research methods, high temperature gas chromatography and other diagnostic methods. However, such studies are long-term in time and usually lead to the destruction of researched sample.

It should be noted that the existing methods of control - organoleptic, chemical, physical, - although reliable, but morally and technically obsolete [11, 12], and do not correspond to the current level of quality control of products of beekeeping [13, 14]. An urgent need for modern methods of quality control $[15,16]$ is due to the fact that fake beeswax is a direct threat to the existence of honey bees, and can negatively affect the quality of all products of beekeeping.

The purpose of the research was to determine the characteristics of the infrared spectra of reflection and absorption of beeswax, as well as wax with the content of impurities in it, in particular paraffin and ceresin.

Research of wax raw materials by obtaining IR reflection spectra does not foresee the use of reagents and allows identification of beeswax, as well as draw conclusions about its falsification. This method is fast, direct and non-destructive.

These benefits of the method allow you to save time and money, and also allow you to explore more samples per unit time.

The use of high-quality natural beeswax is a necessary condition for obtaining organic (natural) bee products [17-20].

\section{Materials and methods}

\section{Materials}

Wax was obtained on the apiary of the Kyiv-Svyatoshinsky district of Kyiv region 20 years ago by melting old honeycomb in a steam kettle. The wax was stored in a dark place at room temperature in the form of blocks of cylindrical shape with a diameter of 30 
centimeters and a height of 10 centimeters, in a closed package (sack) of dense fabric. Paraffin used in medicine was used for conducting experiments.

Cerezin was taken at the enterprise of the wax processing industry, which got there in the form of counterfeit raw materials. In the process of chemical analysis, it was found that the test sample is ceresin, and has nothing to do with beeswax. According to external signs (color, plasticity, fragility, structure of breakage, etc.) the sample was identical to natural beeswax, which made it impossible to identify it without the use of physico-chemical methods of analysis.

Before the beginning of the research, the samples were melted to a liquid state at a minimum melting point ( 65 degrees Celsius). Subsequently, the liquid was poured into a special form, where it was cooled to room temperature, and hardened. Thus, three samples were obtained: natural beeswax, paraffin and ceresin. Similar samples were obtained with different concentrations of paraffin and ceresin in natural beeswax. The relative homogeneity of the samples was obtained by mixing the components in the melting process, their small mass and, as a result, a fairly small hardening time (about a few minutes). The above factors made it possible to avoid explicit stratification of the sample, due to a slightly different density of its components. The diameter of the cylindrical specimens was $5 \mathrm{~cm}$ and their height was $5 \mathrm{~mm}$, the dimensions correspond to the cuvette of the Infrapid-61 infrared diffraction reflector. During solidification a smooth (glossy) surface was formed.

Separately, to increase the accuracy of the experiment, new samples were prepared in analogy to the previous one, with only one difference: natural beeswax was taken from the swarm family. As is known, during the rebuilding of honeycombs, bees take wax from the very beeswax, adding only about 20 percent of their wax to newly built honeycombs. That is, if the beeswax, contaminated by impurities, enters the apiary, then after the melting process these impurities will be present in wax. This will greatly complicate the conduct of the experiment [21].

To obtain spectra of diffuse reflection in the near infrared region, each sample was mechanically shredded with the device that is a set of metal equidistant knives of the same size.

For IR absorption spectroscopy, the samples were mixed with the $\mathrm{KCl}$ powder and pressed as pellets. The reference samples represented pure wax, cerezine and paraffin material. In order to study the effect of wax contamination by cerezine or paraffin, certain amount of wax was mixed with one or both latter materials in different proportions. The typical spectra here are presented for samples with approximately equal proportions of the components in the mix.

\section{Research methods}

The reflection spectra from a smooth surface and shredded samples were researched by using the Infrapid-61 spectrometer in the near infrared range from 1330 to $2370 \mathrm{~nm}$. The spectrometer initially recorded the reflectance spectrum from reference $\mathrm{I}_{0}$ (component part of the instrument), then a reflection spectrum from the researched sample I was obtained. The spectra are represented as the reflectivity of $\mathrm{R}$ in relative units (the ratio of the intensities $\mathrm{I} / \mathrm{I}_{0}=\mathrm{R}$ ), depending on the wavelength in $\mathrm{nm}$.

The Luminar 5030 spectrometer recorded reflection spectra from the unprepared surface of the samples. Each sample was scanned 150 times in $1 \mathrm{~nm}$ increments. By averaging the results, reflectance spectra were obtained for each object of the research. The process of scanning one sample lasted about 7 seconds. 
IR absorption was studied using a dual-beam SPECORD M- 80 spectrophotometer in the 4000 to $800 \mathrm{~cm}^{-1}$ range. As all the samples demonstrated similar fingerprints near 3000 $\mathrm{cm}^{-1}$ corresponding to $\mathrm{CH}_{3}$ and $\mathrm{CH}_{2}$ stretching, the spectra below are given only in the region of $1900-600 \mathrm{~cm}^{-1}$, where characteristic IR vibrations of the polymers are displayed [22-28].

\section{Results and discussion}

\section{NIR reflection research}

Infrared reflection spectra from smooth surfaces of several samples $(\mathrm{P}$ - paraffin, $\mathrm{C}-$ Ceresin, W - Wax, WC - a mixture of beeswax and ceresin, WCP - a mixture of wax paraffin and ceresin, WP - a mixture of wax and paraffin) are shown in Figure 1. All the spectra have a similar structure. There are two clearly expressed maxima of 1509 and 1581 $\mathrm{nm}$ (features $\mathrm{c}$ and e in Figure 1) and more than four minima, in particular at 1415, 1533, 1725 , and $2254 \mathrm{~nm}$ (features b, d, f, g). The highest intensity in the reflection spectrum corresponds to the wavelength of $1581 \mathrm{~nm}$.

Analyzing the ratio of the maxima of the corresponding spectra for wavelengths of 1510 and $1581 \mathrm{~nm}$ (Table 1), we can conclude that the parameter $\alpha$, which is equal to the ratio $\mathrm{R}(1581) / \mathrm{R}(1510)$, varies from 1.115 to 1.265 . The smallest value $\alpha=\frac{R_{W(1581)}}{R_{W(1510)}}=1.115$ corresponds to natural beeswax, and the maximum value corresponds to ceresin $\alpha=\frac{R_{W(1581)}}{R_{W(1510)}}=1.265$. Among the spectral features it is worthwhile to mention the characteristic intervals between extremums (Figure 1, Table 2): $\mathrm{BC}=94, \mathrm{CE}=72, \mathrm{EF}=145 \mathrm{~nm}$.

After shredding the sample the infrared spectrum of diffuse reflection did not undergo significant changes, the most intense spectral maxima did not change its position (Figure 4), but the redistribution of spectral lines by intensity was carried out. There were pronounced differences in the region from 1723 to $2400 \mathrm{~nm}$ (Figure 4), in contrast to the spectra obtained from the smooth surface of the sample (Figure1).

Analyzing the positions of the spectral line maxima (Figure1) at wavelengths of 1581 and $1510 \mathrm{~nm}$ (Table 1), it can be noted that they are located in the following sequence $\mathrm{Rp}>\mathrm{R}_{\mathrm{WP}}>\mathrm{R}_{\mathrm{WC}}>\mathrm{R}_{\mathrm{WCP}}>\mathrm{R}_{\mathrm{C}}>\mathrm{R}_{\mathrm{W}}$.

The coefficient $\alpha$ for the reflection spectra from the flat surface is $\sim 1.2$, and for reflection spectra from shradded samples is $\sim 1.1$ (Table 1 and 2).

Figure 5 presents the IR reflection spectra in the spectral range from 1100 to $1350 \mathrm{~nm}$, obtained with the device Luminar 5030. The horizontal axis deferred wavelength in nanometers, while the vertical axis optical density is $\lg 1 / \mathrm{R}$, where $\mathrm{R}$ - reflecting the ability of the body.

Differences in intensity of the spectral characteristics of the researed samples at a wavelength of $1212.5 \mathrm{~nm}$ allow to make conclusions concerning presence of impurities (wax and ceresin) in the researched samples.

Spectral maxima at the specified wavelength are located in the following sequence $\mathrm{R}_{\mathrm{P}}>\mathrm{R}_{\mathrm{W}}>\mathrm{R}_{\mathrm{WCP}}>\mathrm{R}_{\mathrm{WC}}>\mathrm{R}_{\mathrm{WP}}>\mathrm{R}_{\mathrm{C}}$. 
Table 1

Ratio of the intensities of the spectral maxima for 1510 and $1581 \mathrm{~nm}$.

Smooth surface

Table 2

Ratio of the intensity of the spectral maxima for 1510 and $1581 \mathrm{~nm}$. Shredded sample

\begin{tabular}{|c|c|c|c|}
\hline Sample & $\mathbf{R}_{\mathbf{1 5 1 0}}$ & $\mathbf{R}_{\mathbf{1 5 8 1}}$ & $\mathbf{R}_{\mathbf{1 5 8 1}} / \mathbf{R}_{\mathbf{1 5 1 0}}$ \\
\hline $\mathbf{W}$ & 0.309 & 0.357 & 1.155 \\
\hline $\mathbf{P}$ & 0.318 & 0.397 & 1.248 \\
\hline $\mathbf{C}$ & 0.310 & 0.392 & 1.265 \\
\hline $\mathbf{W P}$ & 0.375 & 0.448 & 1.195 \\
\hline $\mathbf{W C}$ & 0.328 & 0.394 & 1.201 \\
\hline $\mathbf{W C P}$ & 0.318 & 0.394 & 1.239 \\
\hline
\end{tabular}

\begin{tabular}{|c|c|c|c|}
\hline Sample & $\mathbf{R}_{\mathbf{1 5 1 0}}$ & $\mathbf{R}_{\mathbf{1 5 8 1}}$ & $\mathbf{R}_{\mathbf{1 5 8 1}} \mathbf{R}_{\mathbf{1 5 1 0}}$ \\
\hline $\mathbf{W}$ & 0.879 & 0.932 & 1.06 \\
\hline $\mathbf{P}$ & 0.743 & 0.827 & 1.11 \\
\hline $\mathbf{C}$ & 0.727 & 0.806 & 1.12 \\
\hline $\mathbf{W P}$ & 0.792 & 0.857 & 1.08 \\
\hline $\mathbf{W C}$ & 0.757 & 0.824 & 1.09 \\
\hline $\mathbf{W C P}$ & 0.799 & 0.874 & 1.09 \\
\hline
\end{tabular}

Characteristic intervals between spectral extremums (Figure 1)

Table 3

\begin{tabular}{|c|c|c|c|c|}
\hline Extremum & Coordinate & & Segment & Length of the segment, nm \\
\hline A & 1397 & & AB & 18 \\
\hline B & 1415 & & BC & 94 \\
\hline C & 1510 & CD & 24 \\
\hline D & 1533 & DE & 48 \\
\hline E & 1581 & EF & 145 \\
\hline F & 1726 & FG & 528 \\
\hline G & 2254 & GH & 45 \\
\hline H & 2299 & HI & 57 \\
\hline I & 2356 & & \\
\hline & & & \\
\hline
\end{tabular}

The $\mathrm{W}_{\text {original }}$ spectral line (Figure 5) corresponds to a rough (not molded) sample of beeswax obtained on an apiary 20 years ago. Spectral line $\mathrm{W}$ is obtained from a melted sample. The indicated differences in the infrared reflection spectra can be used in obtaining information concerning the history of the production of wax raw materials.

In the article [1] a relatively new direct method for the investigation of wax was proposed, without the use of chemical reagents. The method involves the use of IR spectroscopy in the range from 4000 to $650 \mathrm{~cm}^{-1}$. It allows you to identify beeswax and detect fake (impurities). In the described method, the absorption coefficient was recorded, namely the ratio: $I_{1739 \mathrm{~cm}^{-1}} / I_{2852 \mathrm{~cm}^{-1}}, I_{1714 \mathrm{~cm}^{-1}} / I_{2852 \mathrm{~cm}^{-1}}, I_{1739 \mathrm{~cm}^{-1}} / I_{1714 \mathrm{~cm}^{-1}}$. The results of the studies were confirmed by high temperature gas chromatography. The difference between this work and the previous one is that the absorption and reflection spectroscopy was used. The registration of absorption spectra took place in the spectral range from 1900 to $600 \mathrm{~cm}^{-1}$, and the reflectance spectra were recorded in the range from 1500 to $2400 \mathrm{~nm}$. 


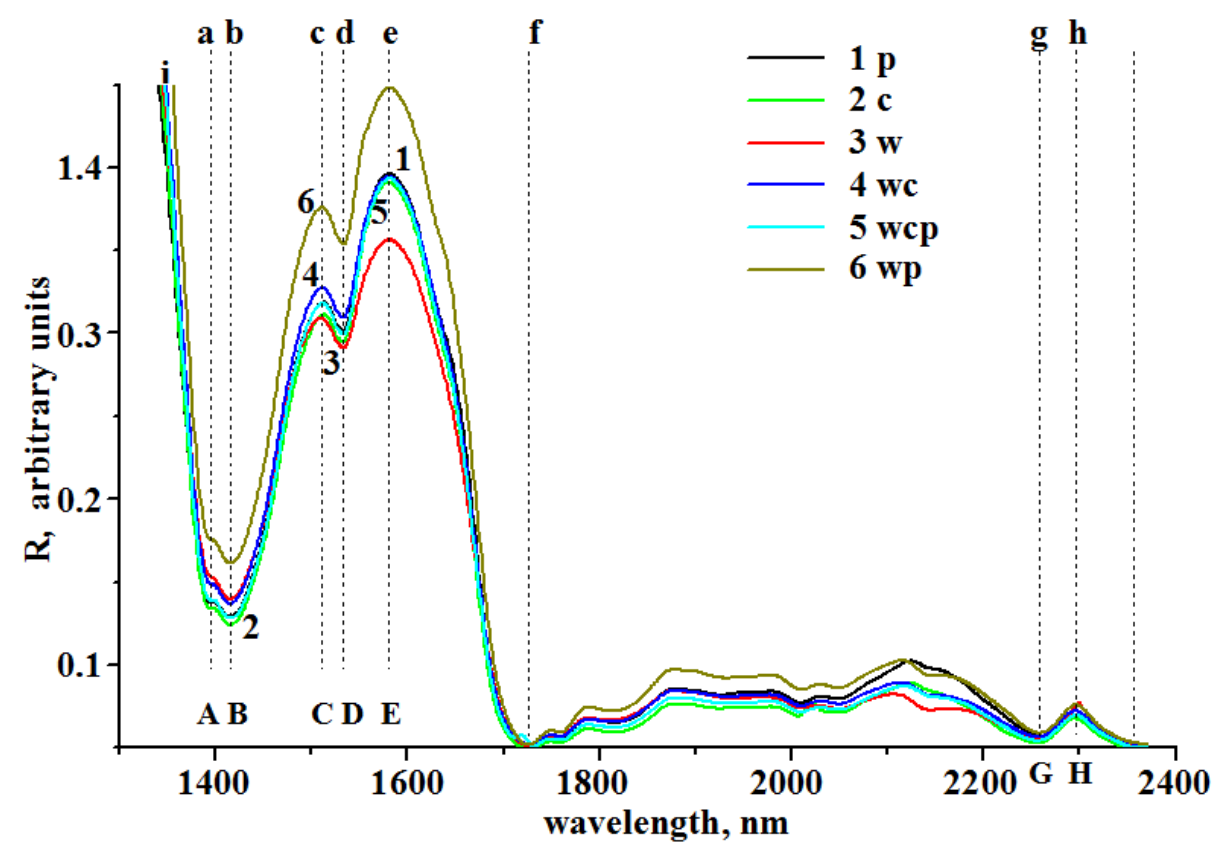

Figure 1. IR reflection spectra. Smooth (glossy) surface of the samples:

$\mathbf{p}$ - paraffin, $\mathbf{c}$ - ceresin, $\mathbf{w}$ - natural beeswax, wc - a mixture of wax and ceresin, wcp - a mixture of bee wax, ceresin and paraffin wax, wp - a mixture of wax and paraffin

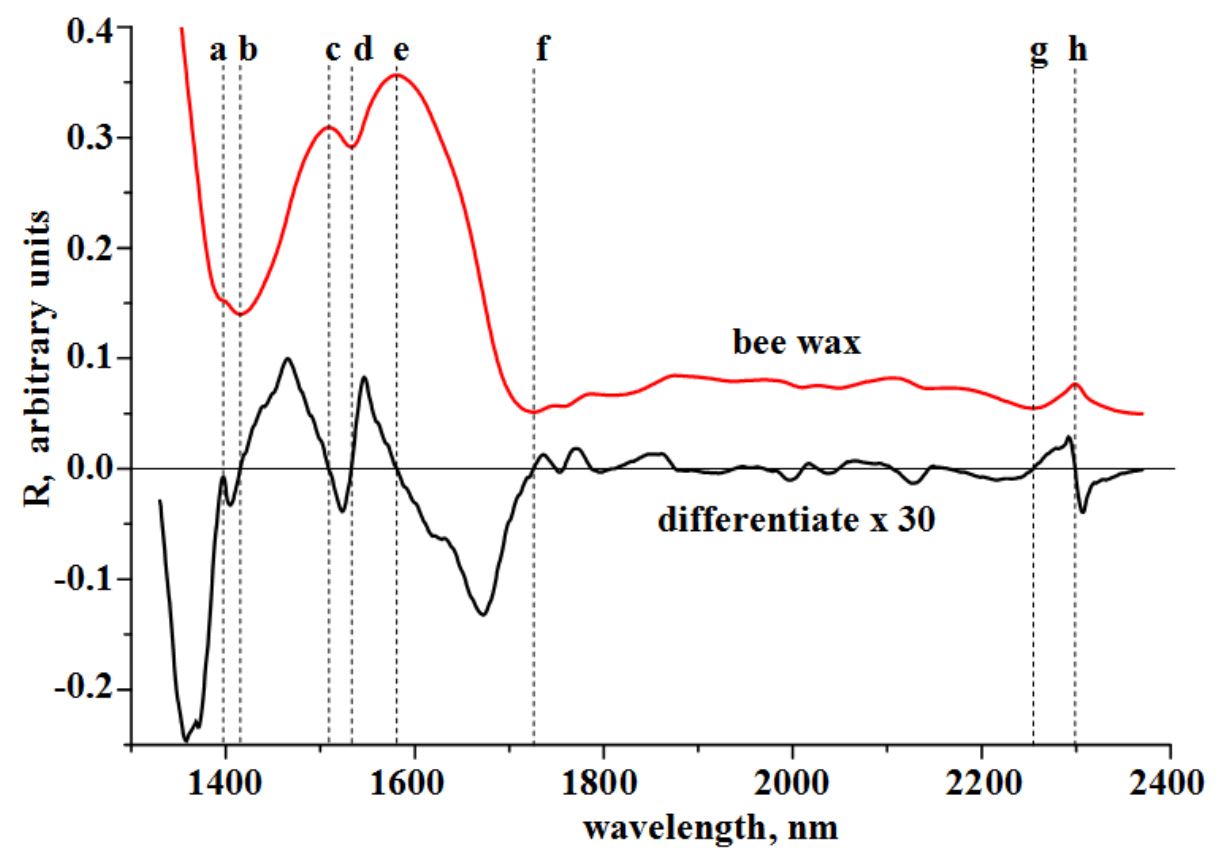

Figure 2. IR reflection spectrum of natural beeswax and its first derivative 


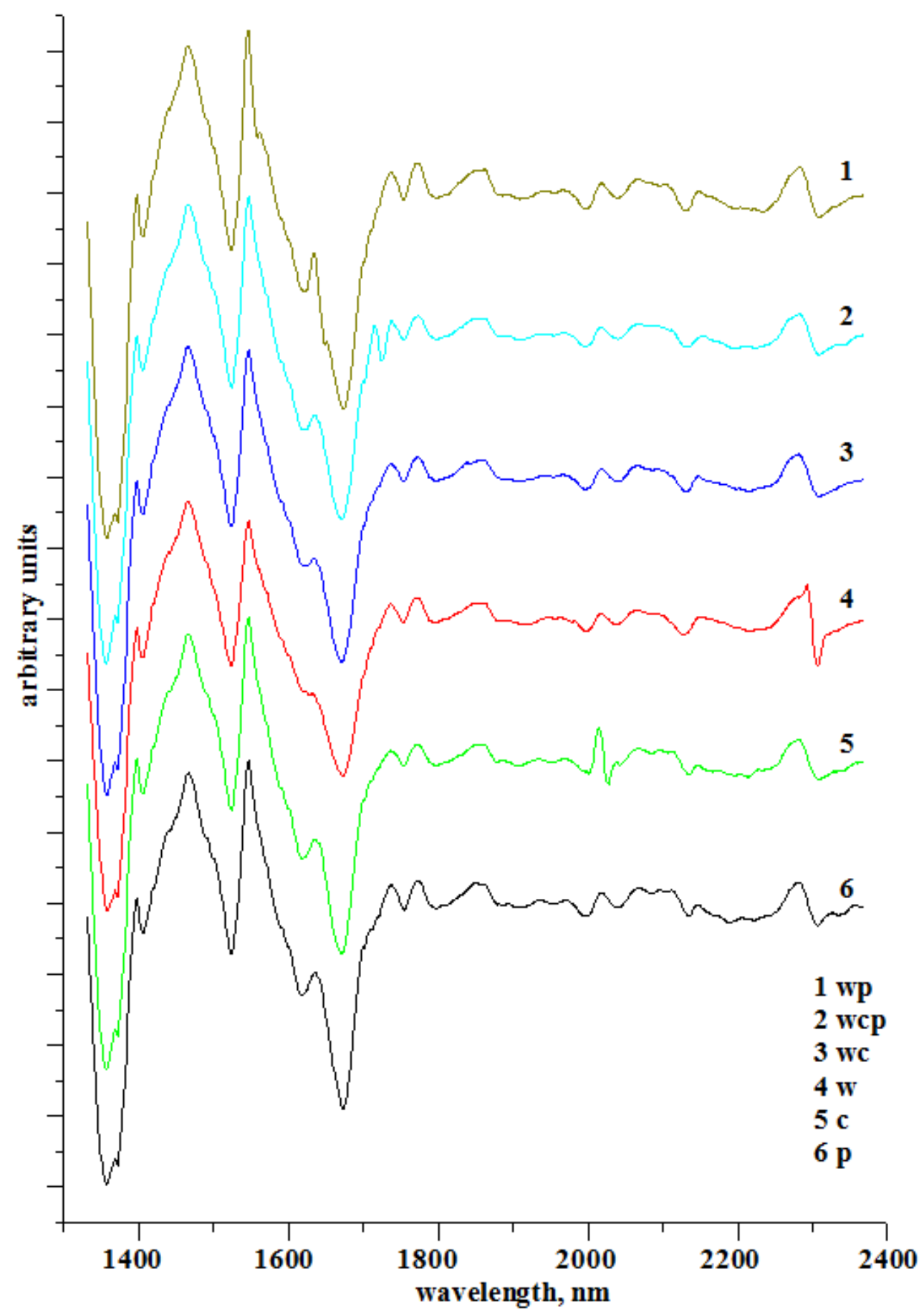

Figure 3. First derivatives of IR reflection spectra from a smooth surface of samples 


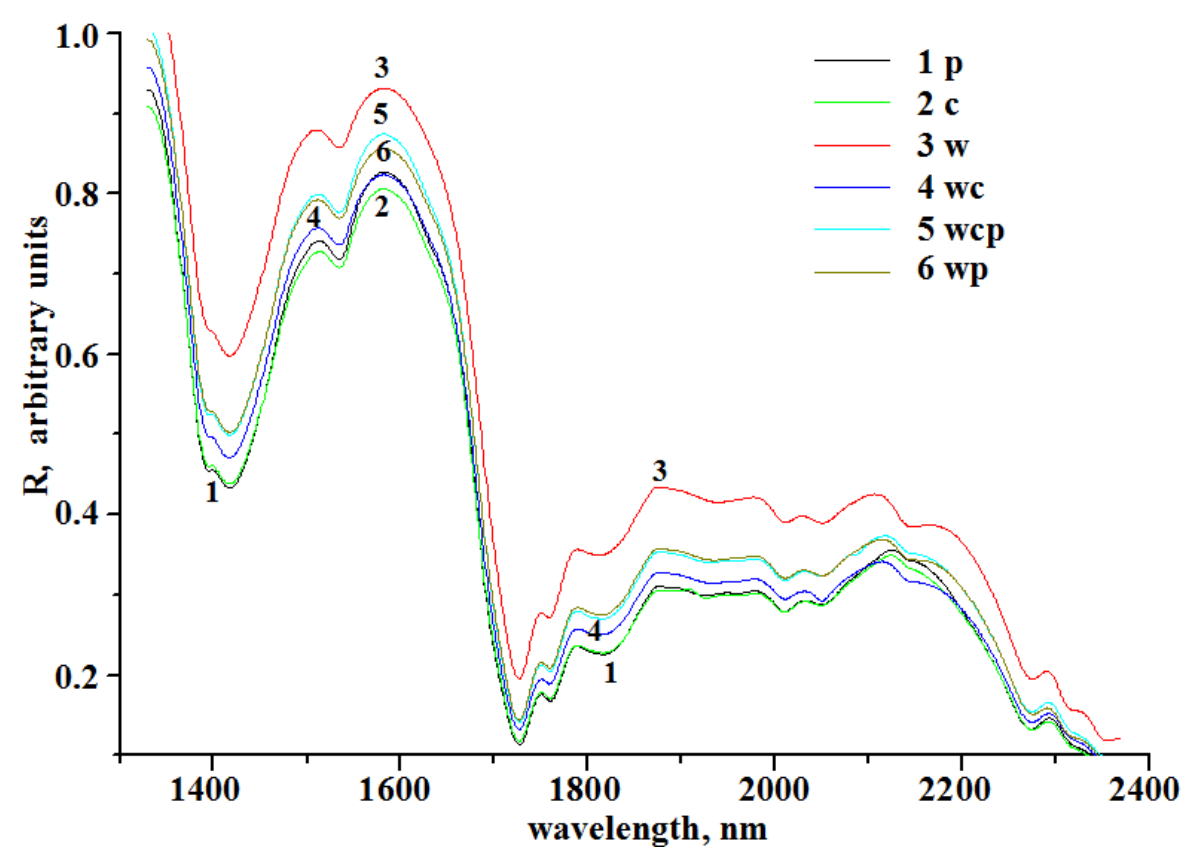

Figure 4. IR spectrum of diffuse reflection of shredded samples

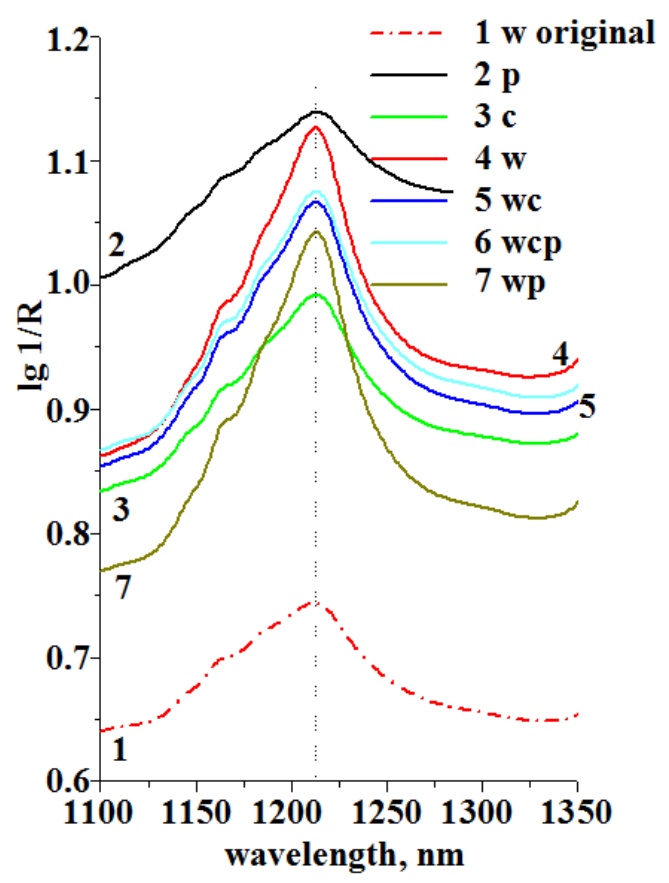

Figure 5. IR reflection spectra of waxy substances 
Wax is considered to be a fairly stable compound, with virtually unlimited shelf life, provided that proper storage conditions are met. At the same time, in the long-term storage, especially in non-leakproof containers at high temperatures, the surface of the sample undergoes certain changes in the physical and chemical parameters, which visually manifests itself in the change of color, and as a consequence in the features of the reflection spectra, and so on. This fact needs to be taken into account in optical studies, since the information received with the help of infrared reflection spectroscopy essentially depends on the state of the surface of the sample.

To some inconvenience of the use of IR reflection spectroscopy one can attribute the fact that the spectra have a similar structure, and it is difficult to distinguish them visually from each other (Figure 1, 4). The proposed research methodology needs improvement in the detection of impurities of low concentration (several percent and less). Interpretation of the results may be complicated if there is a large number of impurities of different chemical nature. In studies, it is necessary to take into account the state of the surface of the sample, and if necessary, to shred (break) the sample, or to melt it. In a case of presence of a large amount of water in beeswax (more than 20\%) the use of infrared spectroscopy is ineffective.

\section{IR absorption research}

Typical spectra of IR absorption of the neat components are shown in Figure 6.

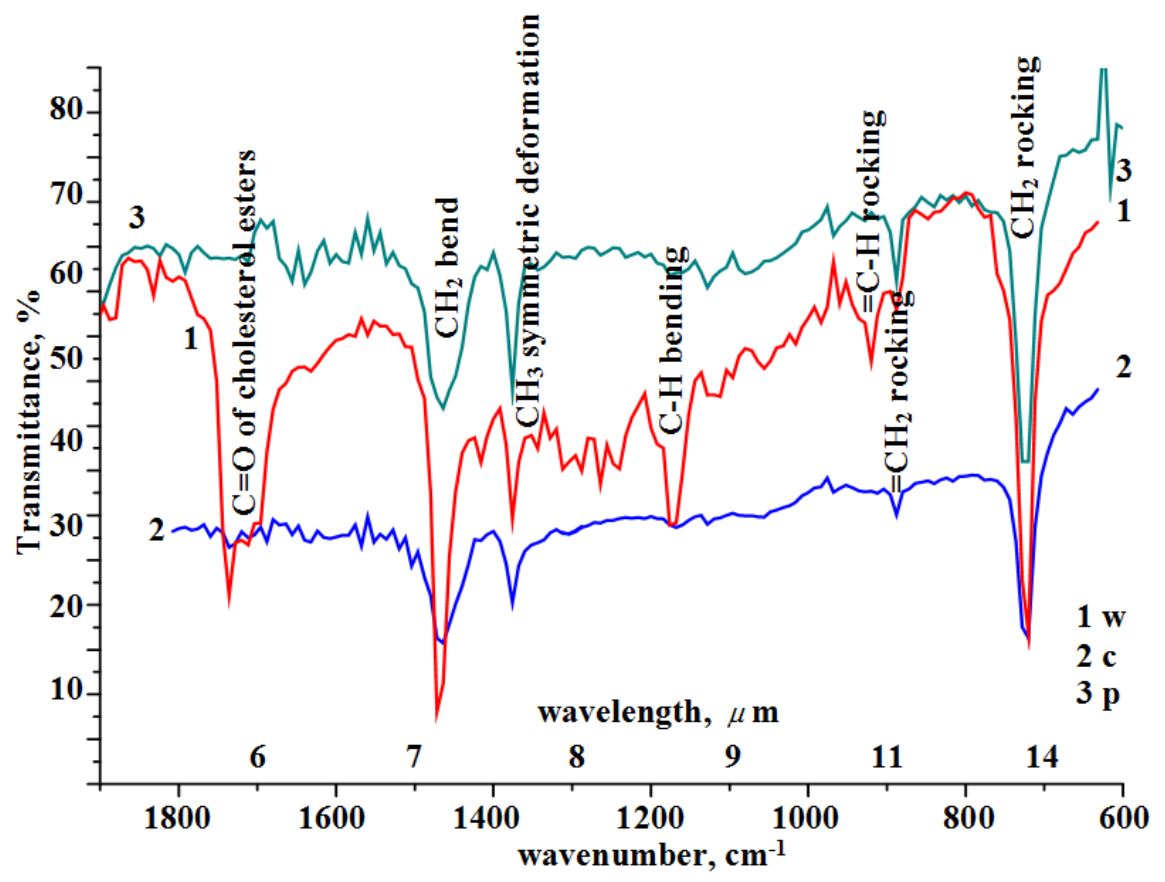

Figure 6. IR spectra of (1) wax, (2) ceresin and (3) paraffin reference samples

All the samples demonstrate similar bands, i.e., at $1470 \mathrm{~cm}^{-1}$ corresponding to $\mathrm{CH}_{2}$ bending, $1376 \mathrm{~cm}^{-1}$ corresponding to $\mathrm{CH}_{3}$ symmetric deformation, $1170 \mathrm{~cm}^{-1}$ corresponding to $\mathrm{C}-\mathrm{H}$ bending, 888 and $720 \mathrm{~cm}^{-1}$ corresponding to $\mathrm{CH}_{2}$ rocking. The above features are typical for hydrocarbon chains and reflect the fact that the compounds have similar chain 
fragments. However, one can distinguish different proportion of the above band intensities. Particularly, the different proportion of $\mathrm{CH}_{2}$ and $\mathrm{CH}_{3}$ bands suggests that hydrocarbon chains of wax molecules are longer than those of paraffin and cerezine studied. One more difference is that the spectrum of wax is more reach than those of paraffin and cerezine. Particularly, the wax samples demonstrate a strong $\mathrm{C}=\mathrm{O}$ vibration at $\sim 1736 \mathrm{~cm}^{-1}$ corresponding to cholesterol esters. This band is a characteristic feature which allows one to identify wax among other hydrocarbon compounds.

The mixtures of wax with other compounds demonstrate $\mathrm{CH}, \mathrm{CH}_{2}$ and $\mathrm{CH}_{3}$ bending and rocking vibrations in IR spectra characteristic for all hydrocarbons used (Figure7).

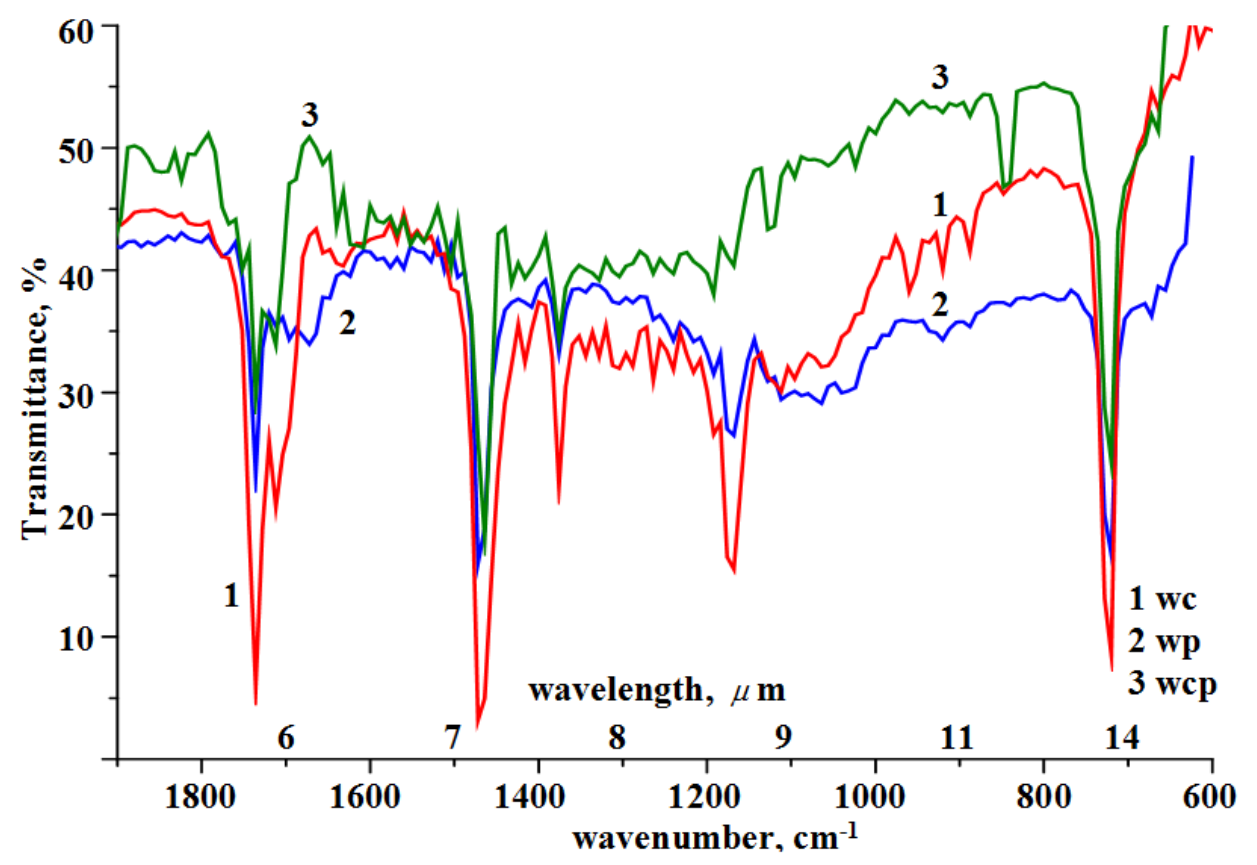

Figure 7. IR spectra of mixtures of (1) wax plus ceresin, (2) wax plus paraffin and

The spectra are also enriched with the strong $\mathrm{C}=\mathrm{O}$ vibration at $\sim 1736 \mathrm{~cm}^{-1}$ indicative of the presence of wax. However, in the mix samples, this band has a more complex structure compared to the neat wax. In fact, the $\mathrm{C}=\mathrm{O}$ band is splitting in the mixtures, with a strong component at $\sim 1736 \mathrm{~cm}^{-1}$ for all the samples accompanied by a smaller red-shifted one. Position of the latter component is dependent on the mixture composition: for the waxcerezine mixture it is at $1712 \mathrm{~cm}^{-1}$, for the wax-paraffin mixture it is at $1672 \mathrm{~cm}^{-1}$, and for the wax-cerezine-paraffin mixture it is at $1712 \mathrm{~cm}^{-1}$ again. The splitting and shift of the $\mathrm{C}=\mathrm{O}$ band is related to the different environment for the carbonyl group in the mix samples, when part of these groups remains in the native wax environment whereas the other in the foreign paraffin or ceresin environment, respectively. In fact, the spectrum of the neat wax (Figure 6) also contains the component at $1712 \mathrm{~cm}^{-1}$, however, this component is less resolved due to broadening of the $\mathrm{C}=\mathrm{O}$ band itself, suggesting more polar environment for 
the carbonyl group in the wax. The different broadening of the $\mathrm{C}=\mathrm{O}$ band is shown in Table 4 and the factor can be used for identification of the contaminant in the bee wax itself.

Table 4

Full width at half maximum (FWHM) of the $\mathrm{C}=\mathrm{O}$ band in the neat wax and mixed samples

\begin{tabular}{|l|c|c|c|c|}
\hline Composition & W & WC & WP & WCP \\
\hline FWHM $\left(\mathrm{cm}^{-1}\right)$ & 62 & 45 & 20 & 43 \\
\hline
\end{tabular}

Thus, our results evidence that hydrocarbon contaminants in the bee wax are associated with narrowing of the $\mathrm{C}=\mathrm{O}$ band at $\sim 1736 \mathrm{~cm}^{-1}$. This spectroscopic feature can be used for further quantitative analysis of the purity of the bee wax itself.

\section{Conclusions}

1. Infrared reflection spectra (in the range of wavelengths $1330-2370 \mathrm{~nm}$ ) from smooth surfaces of samples (paraffin, ceresin, wax, a mixture of beeswax and ceresin, a mixture of wax paraffin and ceresin, a mixture of wax and paraffin) have a similar structure, but there are two clearly expressed maxima of different intensity at wavelengths of 1510 and $1581 \mathrm{~nm}$.

2. The ratio of the intensity of the reflection spectra at characteristic wavelengths $\alpha=\mathrm{R}_{\mathrm{w}}(1581) / \mathrm{R}_{\mathrm{w}}(1510)$ varies from 1.115 (natural bee wax) to 1.265 (ceresin).

3. The maximum intensity of optical density is observed at a wavelength of $1212.5 \mathrm{~nm}$, which can be used to identify the wax and allow conclusions to be made regarding the aging of the sample.

4. Infrared spectra of diffuse reflection of shredded samples will not undergo significant changes in comparison with spectra from a smooth surface. The most intense spectral maxima do not change their position, but there is a redistribution of spectral lines by intensity.

5. The different proportion of $\mathrm{CH}_{2}$ and $\mathrm{CH}_{3}$ bands suggests that hydrocarbon chains of wax molecules are longer than those of paraffin and cerezine studied. One more difference is that the spectrum of wax is more reach than those of paraffin and cerezine. Particularly, the wax samples demonstrate a strong $\mathrm{C}=\mathrm{O}$ vibration at $\sim 1736$ $\mathrm{cm}^{-1}$ corresponding to cholesterol esters. This band is a characteristic feature which allows one to identify wax among other hydrocarbon compounds.

\section{References}

1. Abhay Dinker, Madhu Agarwala, Agarwalb G.D. (2017), Experimental Study on Thermal Performance of Beeswax as Thermal Storage Material, Materials Today: Proceedings, 4 (9), pp. 10529-10533.

2. Francesca Giampieria, José L. Quilesb, Francisco J. Orantes-Bermejo (2018), Are byproducts from beeswax recycling process a new promising source of bioactive compounds with biomedical properties?, Food and Chemical Toxicology, 112, pp. 126133. 
3. Filippo Fratini, Giovanni Cilia, BarbaraTurchi, Antonio Felicioli (2016), Beeswax: A minireview of its antimicrobial activity and its application in medicine, Asian Pacific Journal of Tropical Medicine, 9 (9), pp. 839-843.

4. Miroslava Kacániová1, Vukovic N., Chlebo R. et al. (2012), The antimicrobial activity of hohey, bee, Arch. Biol. Sci., 64 (3), pp. 927-934.

5. Regueira Neto M.S., Saulo Relison Tintino, Ana Raquel Pereirada Silva et al. (2017), Seasonal variation of Brazilian red propolis: Antibacterial activity, synergistic effect and phytochemical screening, Food and Chemical Toxicology, 107(B), pp. 572-580.

6. Basharat Yousuf, Ovais Shafiq Qadri, Abhaya Kumar Srivastav (2018), Recent developments in shelf-life extension of fresh-cut fruits and vegetables by application of different edible coatings: A review, LWT, 89, pp. 198-209.

7. Serra Bonvehi J., Orantes Bermejo F.J. (2012), Detection of adulterated commercial Spanish beeswax, Food Chemistry, 132 (1), pp. 642-648.

8. Jorge Harrieta, Juan Pablo Campáa, Mauricio Grajales et al. (2017), Agricultural pesticides and veterinary substances in Uruguayan beeswax, Chemosphere, 177, pp. 77-83.

9. Monia Perugini, Serena M. R. Tulini, Daniela Zezza et al. (2018), Occurrence of agrochemical residues in beeswax samples collected in Italy during 2013-2015, Science of The Total Environment, 625, pp. 470-476.

10. Pau Calatayud-Vernicha, Fernando Calatayud, Enrique Simó, Yolanda Picóa (2017), Occurrence of pesticide residues in Spanish beeswax, Science of The Total Environment, 605-606, pp. 745-754.

11. Miguel Maia, Ana I. R. N. A. Barros, Fernando M. Nunes (2013), A novel, direct, reagent-free method for the detection of beeswax adulteration by single-reflection attenuated total reflectance mid-infrared spectroscopy, Talanta, 107, pp. 74-80.

12. Miguel Maia, Fernando M. Nunes (2013), Authentication of beeswax (Apis mellifera) by high-temperature gas chromatography and chemometric analysis, Food Chemistry, 136(2), pp. 961-968.

13. Kamila Mitrowska, Maja Antczak (2015), Determination of sulfonamides in beeswax by liquid chromatography coupled to tandem mass spectrometry, Journal of Chromatography B, 1006, pp. 179-186.

14. Sonia Herrera López, AnaLozano, AlexisSosa et al. (2016), Screening of pesticide residues in honeybee wax comb by LC-ESI-MS/MS. A pilot study, Chemosphere, 163, pp. 44-53.

15. Hakme E., Lozano A., Gómez-Ramos M. et al. (2017), Non-target evaluation of contaminants in honey bees and pollen samples by gas chromatography time-of-flight mass spectrometry, Chemosphere, 184, pp. 1310-1319.

16. Jiménez J.J., Bernal J.L., M.J. del Nozal et al. (2006), Sample preparation methods for beeswax characterization by gas chromatography with flame ionization detection, Journal of Chromatography A, 2, pp. 262-272.

17. Nadezhda A. Golubkina, Sergey S. Sheshnitsan, Marina V. Kapitalchuk, Erdene Erdenotsogt (2016), Variations of chemical element composition of bee and beekeeping products in different taxons of the biosphere, Ecological Indicators, 6, pp. 452-457.

18. Ionut Razvan Dobre, Andrei Marmandiu, Gabriel Gajaila et al. (2017), Prevention of diseases in the beekeeping holdings - An essential condition for obtaining organic honey, Journal of Biotechnology, 256, p. S68 
19. Natalia Gérez, Andrés Pérez-Parada, María Verónica Cesio, Horacio Heinzen (2017), Occurrence of pesticide residues in candies containing bee products, Food Control, 72, Part B, pp. 293-299

20. Livia, P Patrizio, M Cinzia, M Enzo (2003), Organic Beekeeping and Acaricide Residues in Beewax. Research in the Lazio Region (Central Italy), Apiacta, 38, pp. 4045.

21. Vassya Bankova, Milena Popova, Boryana Trusheva (2018), The phytochemistry of the honeybee, Phytochemistry, Vol. 155, pp. 1-11.

22. Niewitetzki O, Tillmann P, Becker H.C, Mollers C. (2010), A new near-infrared reflectance spectroscopy method for high-throughput analysis of oleic acid and linolenic acid content of single seeds in oilseed rape (Brassica napus L.), J. Agric. Food Chem., 58, pp. 94-100.

23. Wai Lam Yip, Ingvil Gausemel, Sverre Arne Sande, Knut Dyrstad (2012), Strategies for multivariate modeling of moisture content in freeze-dried mannitol-containing products by near-infrared spectroscopy, Journal of Pharmaceutical and Biomedical Analysis, 70, pp. 202-211.

24. Maria Cristina A. Costa, Marcelo A. Morgano, Marcia Miguel C. Ferreira, Raquel F. Milani (2017), Analysis of bee pollen constituents from different Brazilian regions: Quantification by NIR spectroscopy and PLS regression, $L W T, 80$, pp. 76-83.

25. Saeid Minaei, Sahameh Shafiee, Gerrit Polder, Nasrolah Moghadam-Charkari, Saskia van Ruth, Mohsen Barzegar, Javad Zahiri, Martin Alewijn, Piotr M. Kuś (2017), VIS/NIR imaging application for honey floral origin determination, Infrared Physics \& Technology, 86, pp. 218-225.

26. Herrero Latorre C., Peña Crecente R.M., García Martín S., Barciela García J. (2013), A fast chemometric procedure based on NIR data for authentication of honey with protected geographical indication, Food Chemistry, 141(4), pp. 3559-3565.

27. Kuan Wei Se, Raja Kamarulzaman Raja Ibrahim, Roswanira Abdul Wahab, Sib Krishna Ghoshal (2018), Accurate evaluation of sugar contents in stingless bee (Heterotrigona itama) honey using a swift scheme, Journal of Food Composition and Analysis, 66, pp. 46-54.

28. Olena Hrabovska, Hanna Pastukh, Oleksandr Lysyi, Volodymyr Miroshnyk, Nadiya Shtangeeva (2018), The use of enzyme preparations for pectin extraction from potato pulp, Ukrainian Food Journal, 7(2), pp. 215-233.

29. Galnaitytė A., Kriščiukaitienè I., Baležentis T., Namiotko V. (2017), Evaluation of Technological, Economic and Social Indicators for Different Farming Practices in Lithuania, Economics and Sociology, 10(4), pp. 189-202, DOI: 10.14254/2071789X.2017/10-4/15

30. Czyżewski A., Smędzik-Ambroży K (2015), Specialization and diversification of agricultural production in the light of sustainable development, Journal of International Studies, 8(2), pp. 63-73, DOI: 10.14254/2071-8330.2015/8-2/6 


\section{Antimicrobial properties of model drugs in the systemic concept of health}

\section{Mykola Oseyko', Vasyl Shevchyk ${ }^{2}$, Olena Pokryshko ${ }^{3}$}

1 - National University of Food Technology, Kyiv, Ukraine

2 - "Vasyl Shevchyk's eye microsurgery", Chernigiv, Ukraine

3 - Ternopil State Medical University named after I.Ya. Grobachevsky, Ternopil, Ukraine

\section{Keywords:}

KTIOL

Drug

Microorganism

Resistance

E. coli

Antimicrobial

Health

\section{Article history:}

Received

20.04.2018

Received in

revised form

08.09.2018

Accepted

28.09.2018

\section{Corresponding author:}

Mykola Oseyko

E-mail:

nikios@ukr.net

DOI:

$10.24263 / 2304-$

974X-2018-7-3-8

\section{Abstract}

Introduction. We analyzed the antimicrobial efficacy of the investigated preparations of the KTIOL-BF series on standard culture of microorganisms: S. aureus, Escherichia coli, P. aeruginosa and S. saprophyticus.

Materials and methods. The model preparations of the KTIOLBF series (biofunctional) are studied. The preparations are based on vegetable and animal extracts containing iodine solution or do not contain it. As controls, preparations of povidone iodine and chlorophyll are used. The antimicrobial properties of the samples of the preparations were determined by the modified diffusion method ("wall" method) for increasing the upper range of evaluation.

Results and discussion. The scientific basis of this study is the systematic concept of health, developed on the basis of the KTIOL-I ecological-technological system and the physiologically functional system KTIOL-II. The preparation on the basis of herbal extract provided the initial good antimicrobial effect on all microorganisms studied. Introduction to the preparation based on extracts of plants and on the basis of plant and animal extracts with solution of nanosized particles of colloidal silver up to $35 \mathrm{wt}$. \% slightly reduced the antimicrobial effect of the samples relative to $\mathrm{S}$. aureus and S. saprophyticus. The sample on the basis of plant and animal extracts showed a good antimicrobial effect on microorganisms S. Saprophyticus, E. coli, P. aeruginosa. Two samples showed a good antimicrobial effect on all studied microorganisms.

Model samples of the preparation on the basis of two-phase plant modified enzymes produced a very good integral antimicrobial effect on all microorganisms studied. Of these, two samples based on extracts of plants and on the basis of plant and animal extracts showed high antimicrobial effects on the E. coli strain $(30 \mathrm{~mm}$ growth retardation diameter).

The possibility of high antimicrobial action on E. coli strain (30 $\mathrm{mm}$ diameter growth delay) has been confirmed. This is due to the complex action of these two samples on the study of gram-positive and gram-negative strains of microorganisms.

Conclusions. The possibility of high antimicrobial activity of samples on the basis of two-phase plant extract and on the basis of plant extract and iodine solution on strain Escherichia coli was revealed and confirmed. The same specimens showed high and good antimicrobial properties, both in other strains, and in an integral manner. 


\section{Introduction}

Modern livelihoods of Man contributes to the accelerated proliferation of pathogenic and the emergence of resistant microflora, which interacts with human saprophytic microbes and can affect our physical health. Saprophytic microbes are trillions of microbes living on the surface and inside our body.

It is also important for scientists to find evidence that intestinal bacteria use tiny strips of a genetic code called "miRNA" to change the way DNA acts in nerve cells [1].

In prophylaxis and treatment of infectious diseases are crucial the using of functional drugs for general and local therapy and/or the individual application of the systemic concept of health [2].

Kovan M.M. in the review [3] analyzed the possibility of using plant products as antimicrobial agents. The use of and search for drugs and dietary supplements derived from plants have accelerated in recent years. Ethnopharmacologists, botanists, microbiologists, and natural-products chemists are combing the Earth for phytochemicals and "leads" which could be developed for treatment of infectious diseases. While 25 to $50 \%$ of current pharmaceuticals are derived from plants, none are used as antimicrobials. Traditional healers have long used plants to prevent or cure infectious conditions; Plants are rich in a wide variety of secondary metabolites, such as tannins, terpenoids, alkaloids, and flavonoids, which have been found in vitro to have antimicrobial properties. This review attempts to summarize the current status of botanical screening efforts, as well as in vivo studies of their effectiveness and toxicity. The structure and antimicrobial properties of phytochemicals are also addressed. Since many of these compounds are currently available as unregulated botanical preparations and their use by the public is increasing rapidly, clinicians need to consider the consequences of patients self-medicating with these preparations.

In the author's opinion, it would be beneficial to standardize in vitro extraction and testing methods in order to more systematically find and facilitate the interpretation of results.

Gerontologists also recommend starting prevention as early as possible [4-6].

Now we can observe rasing of the microflora and hospital strains resistance to antibiotics and antiseptics, and as results - increasing in the frequency of secondary and postoperative infections [7].

The aim of the study. To reveal the antimicrobial properties of the different investigated specimens KTIOL-BF series, obtained from the systemic concept of health $\left(\mathrm{KTIOL}^{\circledR}\right)[3]$.

Systemic concept of health (The systems KTIOL $^{\circledR}$ ). The system KTIOL-I (Comprehensive Technologies, Engineering, Equipment, Lines) was initially aimed at the synthesis of lipid-containing products of special purpose. The main principles of the system KTIOL-I: providing the structure of the product (preparation) at the micro and nano level; ecological and economic efficiency; a systematic approach to the methodology of producing safe food, pharmaceutical and cosmetic products and drugs'

The system of KIIOL-II (Integrated Therapy of Individual Health Improvement) was initiated from the analysis of indicators of quality and safety of water, food products, dietary supplements and preparations, environmental and endoecological aspects of personal health. The KIIOL-II system includes: hygiene of thoughts (positive thinking and positive mood); sleep hygiene (recovery, rehabilitation, treatment, rehabilitation); prevention (ophthalmologic, dental, endoecological, herrolontal); water is high quality and safe; nutrition organic and health-care; breathing health-curative; Individual systemic 
exercise (walking, massage, swimming, tennis, Scandinavian walking, etc.); meditators and self-adjusting; individual know-how [2, 5, 8].

Means based on vegetable, ethereal oil and other sources. In recent data, we found information about the influence of the molecular structure of derivatives of 4-thiazolidine (about 70 compounds) on their antimicrobial activity was investigated by the QSAR method. Microorganisms were used as reference cultures: Candida albicans, S. Citrobacter freundii, Klebsiella pneumoniae, Pseudomonas aeruginosa and Staphylococcus aureus MSSA [9].

The influence of the evolution of the heterocyclic system on the antimicrobial properties of derivatives of 4-thiazolidines was demonstrated. An important role of electrostatic characteristics of their molecular structure was also shown. The compounds with the highest predictive value of antimicrobial activity against several cultures were selected as a result of virtual screening.

An international team of researchers and the Singapore Institute of Bioengineering and Nanotechnology created a biodegradable polymer. The activity of the polymer was tested on cultures of five ESKAPE pathogens, including Pseudomonas aeruginosa and methicillinresistant Staphylococcus aureus (MRSA). It turned out that the substance destroys bacteria with 99-100 percent efficiency. Scientists also tested the activity and toxicity of the polymer in mice. The dose of polycarbonate needed for the survival of infected animals was lower or comparable to that of antibiotics for three of the four pathogens.

It is known that aqueous solutions of furatsillin, hydrogen peroxide, povidone-iodine (PVI), chlorhexidine, myramistin, alcoholic solutions of boric acid, liniment of syntomycin, ointment of salicylic acid, levorin, myraimystin, chlorhexidine are often used at the local application of medicinal antiseptic drugs. The disadvantage of these drugs is the narrow spectrum of antimicrobial activity, short-term antimicrobial activity, etc.

The paper [7] presents the results of the study of the antimicrobial properties of the antimicrobial agent palisept plus. The high sensitivity of strains of microorganisms (S. aureus, E. coli, K. pneumoniae, P. aeruginosa) to this drug is shown. According to the author's team, the palisept plus on the oral medication ecamotoxin provides an effective antimicrobial action for a long time.

Additional approvement of good antimicrobical activity of 4-thiazolidine was confirmed in another study [11].

Pharmacological screening of antimicrobial activity of synthesized isomanes is carried out.

Identified compounds with the expressive antimicrobial effect that can increase the sensitivity of clinical strains S. aureus and S. Haemolyticus to oxacillin, which can be used to create new combined antimicrobial chemotherapeutic agents.

Chinese, American and Singapore researchers [12] have synthesized a substance with antimicrobial properties that effectively destroys ESKAPE-bacteria, which was resistant to most antibiotics. The acronym ESKAPE combines the names of pathogens that are highly resistant to most antibiotics and cause most hospital infections worldwide.

Chemists and biologists synthesize antimicrobial peptides and polymers. Despite the efficacy and broad spectrum of action, antimicrobial peptides are toxic, and their production is rather expensive. Most of the described antimicrobial polymers are not decomposed and therefore can accumulate in the body and eventually become toxic. In addition, until now, their activity in living organisms has not been practically studied.

Despite the fact that scientists are constantly synthesizing new generations of drugs, bacterial resistance is still a significant problem. 
The antimicrobial activity of the developed dermatological ointment with a two-phase extraction of black poplar kidneys using the method of diffusion into agar (the method of "wells") was studied [14]. As test cultures, eleven different strains of microorganisms were used. The results of microbiological studies have shown that the biphasic extracts of black poplars and ointment on its basis have a expected antimicrobial action against pathogenic microorganisms.

The study was conducted to evaluate the in vitro antibacterial activities of 18 essential oils chemotypes from aromatic medicinal plants against streptococcus S. Pyogenes [15].

The chemical composition of oil was analysed by GC and GC-MS. the reducing power, antioxidant and 2,2-diphenyl-1-picrylhydrazyl (DPPH) radical-scavenging activities of the essential oil were studied. The reducing power was compared with ascorbic acid, and the other activities were compared with 2,6-di-tert-butyl-4-methyl phenol (BHT, butylated hydroxytoluene). The results showed that the activities were concentration dependent. The antioxidant activities of the oil were slightly lower than those of ascorbic acid or BHT, so the oil can be considered an effective natural antioxidant. Antimicrobial activities of the essential oil from the leaves of Origanum syriacum was also determined on 16 microorganisms tested using the agar-disc diffusion method, and showed antimicrobial activity against 13 of these.

Antibacterial activity of essential oils was investigated using disc diffusion method. Minimum Inhibitory Concentration of essential oils was measured using broth dilution method. Out of 18 essential oils tested, 14 showed antibacterial activity against S. pyogenes. Among them Cinnamomum verum, Cymbopogon citratus, Thymus vulgaris CT thymol, Origanum compactum, and Satureja montana essential oils exhibited significant antibacterial activity. The in vitro results suggest that, for patients (if aromatherapy is used) these essential oils, considered as potential antimicrobial agents, should be preferred.

The authors plan additional studies of essential oils in clinical strains regarding the potential clinical use in therapeutic therapy (to determine whether they can effectively replace antibiotics or may be used in combination) [18].

Adiantum Linn. of Adiantaceae family is one of the most common and widely distributed species. Ethnomedicinally, the genus is important and popularly known as "Hansraj" in Ayurvedic System of Medicine.

In the present study its four important species, i.e. Adiantum capillus-veneris, Adiantum peruvianum, Adiantum venustum and Adiantum caudatum were collected and extracted with methanol. These extracts were tested for their antimicrobial agents against five gram positive, six gram negative (including multiresistant bacteria Staphylococcus aureus) and eight fungal strains using standard microdilution assay. The maximum activity was exhibited by the methanolic extract of Adiantum venustum followed by Adiantum capillus-veneris, Adiantum peruvianum and Adiantum caudatum. The methanolic extract of Adiantum capillus-veneris had very low MIC value $(0.48 \mu \mathrm{g} / \mathrm{ml})$ against Escherichia coli whereas, Adiantum venustum extract against Aspergillus terreus with MIC of 0.97 $\mu \mathrm{g} / \mathrm{ml}$. Total phenolic constituents of Adiantum species viz. Adiantum venustum, Adiantum capillus-veneris, Adiantum peruvianum and Adiantum caudatum were $0.81 \%(\mathrm{w} / \mathrm{w}), 0.83 \%$ $(\mathrm{w} / \mathrm{w}), 0.71 \%(\mathrm{w} / \mathrm{w})$ and $0.52 \%(\mathrm{w} / \mathrm{w})$, respectively (as gallic acid equivalent); implying that the observed activity could be related to the amount of phenolics [19].

In [16], the authors studied antimicrobial activity of lipophilic complexes obtained from Galium species. The study was conducted in vitro by agar diffusion. Staphylococcus aureus was found to be the most susceptible to the studied lipophilic complexes. Escherichia coli and Proteus vulgaris showed low sensitivity. Pseudomonas aeruginosa and Bacillus subtilis showed moderate sensitivity. The obtained results provided the basis for 
further in-depth studies of the antimicrobial and antifungal activity of the lipophilic complex of the genus Galium L.

The exponential growth of bacterial resistance to antibiotics raises a problem for clinicians regarding endophthalmitis in postcataract surgery through multidrug-resistant (MDR) organisms. Treatment options are limited and the results are bad. Therefore, prompt surgical prophylaxis provides the best treatment solution. There are currently no recommendations for surgical prophylaxis in patients with bacterial colonization of multiresistant (MDR) organisms.

The current ESCRS (European Society Cataract and Refractive Surgery) recommendation for a 3-minute exposure to $5 \% \mathrm{PVI}$ is effective for gram-negative bacteria and most gram-positive cocci. However, $5 \% \mathrm{PVI}$ is ineffective for enterococci and requires exposure to chlorhexidine for 5 minutes.

\section{Materials and methods}

\section{Materials}

Strains of Gram-positive and Gram-negative microorganisms, were used: S. aureus (ATCC 6538), S. saprophyticus (ATCC 15305), E. coli (ATCC 25922), P. aeruginosa (ATCC 9027). The density of the microbial suspension was determined according to the standard of turbidity 0,5 by McFarland (equal to $1.5 \times 108$ colony-forming units $(\mathrm{CFU}) / \mathrm{ml}$ ).

The study used samples of the KTIOL-BF series. These functional and antioxidant drugs have been obtained on the basis of the systemic concept of health. As model samples, the preparations of the KTIOL-BF (biologically functional) series were used. The preparations KTIOL-BF5, KTIOL-BF6 and KTIOL-BF7 are based on plant extract and iodine solution. The preparations KTIOL-BF25, KTIOL-BF26 and KTIOL-BF27 on the basis of plant and on the basis of plant and animal extracts and solution of nanosized particles of colloidal silver. KTIOL-BF49 based on plant and animal extract and KTIOLBF69 on the basis of plant extract and iodine solution.

The preparations KTIOL-BF31 and KTIOL-BF32 are based on a two-phase plant extract. The preparations KTIOL-BF36, KTIOL-BF37, KTIOL-BF38 and KTIOL-BF39 on the basis of plant extract and iodine solution. Povidone-iodine, PVI (pharmaceutical preparation BETADINE is based on a solution of povidone-iodine, surface-active and auxiliary substances) and Chlorophyllipt (CHL) based on two phases of plant extract were used as controls.

\section{Order of conducting researches}

Analysis of the methodology. Preparation of exploratory strains of Gram-positive and Gram-negative microorganisms, model preparations of the KTIOL-BF series and control drugs. Execution of planned research, processing and discussion of the results, conclusions.

\section{Description of the methodology}

As the references, strains of Gram-positive and Gram-negative microorganisms, were used: S. aureus (ATCC 6538), S. saprophyticus (ATCC 15305), E. coli (ATCC 25922), P. aeruginosa (ATCC 9027). The density of the microbial suspension was determined according to the standard of turbidity 0,5 by McFarland (equal to $1.5 \times 108$ colony-forming units (CFU)/ml) [14]. 
An antimicrobial activity of drug samples were determined by the agar-well diffusion method. In one Petri dish the activities of four or five different samples were studied. The investigated samples were dissolved in formamide in a ratio of 1:10.10 ml of a sterile melted meat peptone agar (MPA) was poured into a Petri dish. After cooling of this medium layer, sterile glass cylinders were placed in it (height $10 \mathrm{~mm}$, internal diameter 6 $\mathrm{mm}$ ) and then $15 \mathrm{ml}$ of melted MPA mixted with overnight suspension of the test-microbe were added. When the second layer of medium became solidified, the cylinders were removed and into the wells that were formed, the $0,5 \mu \mathrm{l}$ of the drug samples were delivered under the aseptic condition. After incubation period for 24 hours at $37{ }^{\circ} \mathrm{C}$ the results were determined. The the inhibition zones (no growth) of the test-microorganisms around wells were measured in millimeteres.

\section{Working out of research results}

According to the diameter of the microbial growth inhibition zone the degree of a susceptibility of microorganisms to the antibacterial solutions were adopted: as high susceptibile to drug sample - if the diameter of the growth inhibition zone of microorganisms exceeded $20 \mathrm{~mm}$; susceptibile if the diameter was from 14 to $20 \mathrm{~mm}$; and low susceptibile - from 8 to $14 \mathrm{~mm}$. All tests were perfomed triplicate and average values were recorded.

After the second layer of the agar was sealed, the cylinders were also removed in the formed wells; the samples of the investigational drugs were $0.3 \pm 0.03 \mathrm{ml}$. In one cup, Petri studied the activity of four or five different samples.

The seeds were incubated at $37^{\circ} \mathrm{C}$. for 48 hours. The results were determined in the presence of zones of growth retardation test-microorganisms, which were clearly visible around the walls.

By the degree of sensitivity of microorganisms to antibacterial solutions, we measured the diameter of the zone of suppression of microorganisms.

As a scientific and practical basis in the planning and implementation of this study, the systemic concept of health [3] was used. This concept includes two systems of KTIOL.

\section{Results and discussion}

Taking into account the principles of the systemic concept of health and the physiologically functional system of KTIOL-II, samples of type KTIOL-BF $[2,8]$ included hydrophilic lipophilic extracts from plant and/or animal raw materials, antioxidants, biologically active and auxiliary components. The results of the study are presented in Tables 1 and 2 .

The analysis of the data in Table 1 in comparison with the control sample PVI the following. From samples KTIOL-BF5, KTIOL-BF6 and KTIOL-BF7 on the basis of initial extracts only sample KTIOL-BF7 provided an initial good effect on all microorganisms being studied.

When the nanoparticles of colloidal silver were introduced into the original extracts (KTIOL-BF5, KTIOL-BF6, KTIOL-BF7), specimens KTIOL-BF25, KTIOL-BF26 and KTIOL-BF27 were respectively obtained. Colloidal silver slightly reduced the antimicrobial effect of these samples on S. aureus and samples KTIOL-BF26 and KTIOLBF27 relative to S. saprophyticus. Note that only a sample of 25 nanoscale colloidal silver showed a good antimicrobial effect on the microorganisms S. Saprophyticus, E. coli, P. aeruginosa examined. 
Table 1

Antimicrobial properties of samples of model_drugs KTIOL-BF on the basis of extracts (in $\mathbf{m m}$, retarded growth zone)

\begin{tabular}{|l|c|c|c|c|}
\hline \multirow{2}{*}{ Drug samples } & \multicolumn{4}{|c|}{ Growth inhibition, mm (Mean \pm SD) } \\
\cline { 2 - 5 } & S. aureus & S. saprophyticus & E. coli & P. aeruginosa \\
\hline Control PVI & $10 \pm 0.2$ & $12 \pm 0.5$ & $10 \pm 0.4$ & $12 \pm 0.2$ \\
\hline KTIOL-BF5 & 0 & 0 & 0 & 0 \\
\hline KTIOL-BF6 & $14 \pm 0.5$ & $12 \pm 0.8$ & 0 & 0 \\
\hline KTIOL-BF7 & $14 \pm 0.3$ & $14 \pm 0.6$ & $18 \pm 0.5$ & $14 \pm 0.4$ \\
\hline KTIOL-BF25 & $12 \pm 0.7$ & $16 \pm 0.4$ & $18 \pm 0.6$ & $16 \pm 0.5$ \\
\hline KTIOL-BF26 & $12 \pm 0.5$ & $12 \pm 0.4$ & $18 \pm 0.5$ & $20 \pm 0.5$ \\
\hline KTIOL-BF27 & $12 \pm 0.4$ & $12 \pm 0.3$ & $14 \pm 0.8$ & $20 \pm 0.6$ \\
\hline KTIOL-BF49 & $16 \pm 0.4$ & $16 \pm 0.5$ & $22 \pm 0.6$ & $24 \pm 0.8$ \\
\hline KTIOL-BF69 & $18 \pm 0.6$ & $16 \pm 0.3$ & $14 \pm 0.3$ & $18 \pm 0.6$ \\
\hline
\end{tabular}

Table 2

Antimicrobial properties of samples of model drugs KTIOL-BF on the basis of extracts with biologically active components (in $\mathrm{mm}$, retarded growth zone)

\begin{tabular}{|c|c|c|c|c|}
\hline \multirow{2}{*}{ Drug samples } & \multicolumn{4}{|c|}{ Growth inhibition, mm (Mean \pm SD) } \\
\cline { 2 - 5 } & S. aureus & S. saprophyticus & E. coli & P. aeruginosa \\
\hline KTIOL-BF31 & $20 \pm 0.4$ & $18 \pm 0.5$ & $18 \pm 0.5$ & $18 \pm 0.3$ \\
\hline KTIOL-BF32 & $24 \pm 0.6$ & $18 \pm 0.6$ & $30 \pm 0.5$ & $16 \pm 0.4$ \\
\hline KTIOL-BF36 & $20 \pm 0.6$ & $18 \pm 0.5$ & $18 \pm 0.7$ & $18 \pm 0.4$ \\
\hline KTIOL-BF37 & $16 \pm 0.5$ & $16 \pm 0.7$ & $22 \pm 0.4$ & $12 \pm 0.5$ \\
\hline KTIOL-BF38 & $24 \pm 0.2$ & $22 \pm 0.6$ & $30 \pm 0.8$ & $20 \pm 0.7$ \\
\hline KTIOL-BF39 & $14 \pm 0.4$ & $14 \pm 0.5$ & $20 \pm 0.6$ & $16 \pm 0.6$ \\
\hline control 52 & $10 \pm 0.3$ & $12 \pm 0.4$ & $10 \pm 0.4$ & $10 \pm 0.4$ \\
\hline
\end{tabular}

Also modified and samples 49 (based on the iodine content extract 7) and 69 (based on the iodine content extract 6 and plant extract) were also studied. Sample KTIOL-BF49 showed a good antimicrobial effect on all microorganisms studied. Sample KTIOL-BF69 (Improved Sample KTIOL-BF6) neutralized the defects of sample KTIOL-BF6 and provided antimicrobial effect on all microorganisms under study.

The analysis of the data in Table 2 in comparison with the control sample 52 (pharmaceutical preparation Chlorophyllipt on the basis of a two-phase plant extract) revealed the following. Samples KTIOL-BF31 and KTIOL-BF32 on the basis of two-phase plant extracts provided a very good integral antimicrobial effect on all investigated microorganisms: S. aureus, S. saprophyticus, E. coli, P. aeruginosa. For the first time, a high antimicrobial effect of samples KTIOL-BF32 and KTIOL-BF38 on strain E. coli was detected.

Modified model samples KTIOL-BF36, KTIOL-BF38 and KTIOL-BF39 (were also studied. Samples KTIOL-BF37 and KTIOL-BF39 showed a good antimicrobial effect on all microorganisms being studied.

The high integral sensitivity to the sample of the preparation KTIOL-BF38 was revealed by all strains of microorganisms examined (the diameter of their growth delay 
exceeded $20 \mathrm{~mm}$ ). Also the possibility of a high antimicrobial action on the E. coli strain (growth delay diameter of $30 \mathrm{~mm}$ ) was confirmed. Also, the possibility of a high antimicrobial action on E. coli strain (diameter growth delay of $30 \mathrm{~mm}$ ) was confirmed. This is due to the complex action of the drug KTYOL-BF38 on the study of gram-positive and gram-negative strains of microorganisms.

\section{Conclusions}

On the basis of analytical and experimental research new data on the antimicrobial properties of samples of model preparations of KTIOL-BF on the basis of two-phase extracts from animal and plant raw materials were obtained.

For the first time the possibility of high antimicrobial action of samples of the preparation of KTIOL-BF32 and38 on the E. coli strain $(30 \mathrm{~mm}$ growth retardation diameter) was confirmed.

It was found that samples of the KTIOL-BF model preparations compared with the control agents (BETADINE /PVI, Chlorophyllipt) showed higher and good antimicrobial pro perties for S. Aureus, S. Saprophyticus, E. coli, P. Aeruginosa and integral strains.

The obtained data confirmed the expediency of further in- depth studies of antimicrobial and antifungal activity of hydrophilic and/or lipophilic drugs of a number of KTIOL in the systemic concept of health, in particular in the treatment of ophthalmic and gerontological prophylaxis, treatment and rehabilitation.

\section{References}

1. Gallagher D. (2018), How bacteria change our mood. The Second Genome, Available at: https://www.bbc.com/ukrainian/features-43919342.

2. Oseiko M., Shevchyk V., Romanovska T (2017), Functional products and preparations in the systemic concept of health, Ukrainian Food Journal, 6(4), p. 661-673.

3. Cowan M.M. (1999) Plant products as antimicrobial agents, Clin. Microbiol.Rev, 12, pp. 564-582.

4. Oseiko N.I., Shevchyk V.I (2015), Gerontological aspects of prevention of ophthalmic diseases in the system KTIOL II, Pharmacology, Pharmaceutical Technology and Pharmacotherapy in Active Longevity: a book of abstracts of the II International Scientific Conference, OIHN, Vilnius, 60, p. 46.

5. Oseyko M.I. (2008), Gerodiyetichni produkty, BAD i geroprotektory v sisteme KTIOL, Molochnaya promyshlennost', 3, pp. 51-56.

6. Grigorov Yu.G. (2005), Funktsional'nyye produkty dlya lyudey starshe vozrastov, Problemy pitaniya, 2, pp. 27-31.

7. Paliy H.K. (2014), Vyvchennya antymikrobnykh vlastyvostey antymikrobnoho preparatu palizepta plyus, Bukovyns'kyy medychnyy byuleten', 71, pp. 114-118.

8. Oseyko M.I. (2006), Tekhnologiya rastitel'nykh masel, Varta, Kyiv.

9. Artemenko A., Muratova E., Atamanyuk D., (2009), QSAR Analysis of Antimicrobial Activity of 4-thiazolidone, Derivatives Comb. Sci., 28, pp. 194-205.

10. Hamouche E., Sarkis D.K. (2012), Evolution of susceptibility to antibiotics of Escherichia coli, Klebsiella pneumoniae, Pseudomonas aeruginosa and Acinetobacter baumanii, University Hospital Center of Beirut, Pathol Biol (Paris), 60(3), pp. 15-20.

11. Derkach G., Golota S., Zasidko V. (2016), The synthesis and the study of antimicrobial properties of 5-r,r'-aminometylene derivatives of thiazolidine-2,4-dione and 4- 
thioxothiazolidine-2-one, Journal of Organic and Pharmaceutical Chemistry, 3(55), pp. 32-36.

12. Willy Chin, Guansheng Zhong, Qinqin Pu (2018), A macromolecular approach to eradicating multidrug-resistant bacterial infections while mitigating drug resistance onset, Nature Communications, 9, Article number: 917.

13. Available at:

http://medaboutme.ru/zdorove/publikacii/stati/sovety_vracha/antibiotiki_ili_bakteriofa gi_v_chem_raznit a_lekarstv/

14. Nikitina N.V., Kuleshova S.A. (2011), Study of the pharmacological action of the ointment with black kidney extracts, Fundamental research, 11, pp. 554-558.

15. Julien Sfeir, Corinne Lefrançois, Dominique Baudoux (2013), In Vitro Antibacterial Activity of Essential Oils against Streptococcus pyogenes, Evidence-Based Complementary and Alternative Medicine, Article ID 269161, p. 9.

16. Ilyina T.V., Goryacha O.V., Toryanik E.L. (2016), Antimicrobial Activity of the Genus Galium L., Pharmacognosy Communications, 6, pp. 42-47.

17. Rourke M.O, Curry A., Kealy N. (2017), Prophylaxis of postoperative endophthalmitis in the setting of multi-drug resistant bacteria, The XXXV Congress of the European Society of Cataract and Refractive Surgeons (ESCRS), 7-11 October, de Lisboa, Portugal.

18. Alma M.H., Mavi A., Yildirim A., Digrak M. (2003), Hirata T. Screening chemical composition and in vitro antioxidant and antimicrobial activities of the essential oils from Origanumsyriacum L. growing in Turkey, Biochem. Pharmacol.Bull., 26, pp. $1725-1729$.

19. Singh M., Singh N., Khare P.B., Rawat A.K.S. (2008), Antimicrobi alactivity of some important Adiantum species used traditionally in indigenous systems of medicine, $J$. Ethnopharmacol, pp. 115, pp. 327-329.

20. Hostettman K. (1998), Strategy of the biological and chemical evaluation of plant extracts, IUPAC, 70, pp. 21-22.

21. Raho G. Bachir, Benali M. (2012), Antimicrobial and antioxidative activities of the essential oils and methanol extracts of Salvia cryptantha (Montbret et Aucher ex Benth.) and Salvia multicaulis (Vahl), Asian Pac J Trop Biomed, 2(9), pp. 739-742.

22. Samoilyk I., Nitsenko V., Bilan Y. (2017). Conceptual modeling of agri-food market development under economy's globalization, Scientific bulletin of Polissia, 3, pp. 5461 . 


\title{
Functional-technological properties of protein composite of animal origin
}

\author{
Natalia Povarova, Liudmyla Melnyk
}

Odesa National Academy of Food Technologies, Odesa, Ukraine

Keywords:

Meat

Protein

Poultry

Additives

Drying

\section{Article history:}

Received 23.06.2018

Received in revised

form 28.08.2018

Accepted 28.09.2018

\section{Corresponding author:}

Liudmyla Melnyk

E-mail:

meladka92net@

gmail.com

DOI: $10.24263 / 2304-$

974X-2018-7-3-9

\section{Abstract}

Introduction. The purpose of the study is to study the functional and technological properties of the obtained protein compositions from poultry meat and to determine the optimum with high quality indices.

Materials and methods. The meat of mechanical treatment, fillet of poultry, hams with skins were studied, which were subjected to microwave-vacuum drying with humidity not more than 5\% and prepared samples - Mepro 85 (the Dutch manufacturer) - animal protein of cattle and Sunprotein vegetable protein.

Results and discussion. The obtained results indicate that the resulting dry powders can bring the finished product closer to a product with a balanced composition, high quality and nutritional value. It has been studied that specimens from the fillet of poultry, hams with skins, and meat of mechanical treatment of poultry contained more than $80-96 \%$ free moisture, which gives the product its use with greater juicy and tender consistency.

At the same time, the best water-retaining ability in the sample from the fillet of poultry is $10.2 \%$ and in Sunprotein $11.4 \%$. The greatest fat-retaining ability was the meat of mechanized treatment of poultry $-13.1 \%$ compared to the sample Mepro $85-5.25 \%$. The emulsifying ability in the sample meat of mechanical treatment of poultry is $73 \%$, which is 20 $25 \%$ higher compared to other samples.

As a result of microbiological research no bacteria of the colon germ, pathogenic microorganisms, including the genus Salmonella, sulfitreducing clostridia were found. The total amount of microorganisms after drying in all samples does not exceed the norm for boiled dried meat $5 \times 10^{3}$. The best result was observed in the sample Sunprotein $-1.8 \times 10^{3}$.

In the sensory analysis, it has been found that the sample of the fillet of poultry has a better outer look and smell, while the consistency is better in meat of mechanical treatment of poultry. It is the most crumbly, inherent in dry powders.

Conclusions. The comparative analysis confirms the high functional and technological properties of samples from the fillet of poultry and meat of mechanical treatment of poultry, as well as being safe for use in meat products. 


\section{Introduction}

The growing standard of living of the population in the conditions of deficiency of animal proteins has led to the intensive development of new trends in meat products, which consists in optimal combination of both meat and non-meal protein-containing food components for obtaining high-quality and biologically valuable foods. [9].

In the meat industry, animal and vegetable protein preparations are used not only as functional additives, which help increase the yield of traditional meat products, but also as the formulation components of combined meat products (milk protein preparations, soybean isolates, protein hydrolyzates, hydrocolloids etc.) [5].

Many scientists contributed significantly to the development of rational approaches to adequate replacement of meat raw materials with protein-containing and non-protein fillers, to improve the indicators of food and biological value and biological efficiency of meat products, their technological characteristics and cost-effectiveness [4]. They are: V.M. Pasychny, R. Tarte, E. Tornberg, P.A. Lofgren, A.I. Zharinov, N.A. Yancheva, M.M. Klimenko, A.Yu. Sokolova and other scientists [10].

Swedish scientist E. Tornberg was engaged in the development of milk protein preparations that had functional and technological properties similar to meat raw materials [2]. American scientist P.A. Lofgren was involved also in the development of milk protein preparations, namely casein sodium [3]. Such a technology has a limited range of applications, since there are people with lactose intolerance.

Arihara K. and Carballo J. were involved in the development of sausage products with the addition of dry meat powder. Campbell R. E., Hunt M. C. studied the methods of drying beef, but the disadvantage of their method is that the product was characterized by increased rigidity and low quality.

Taking into account that the proposed raw material, namely poultry meat, is a product that is rapidly spoiled, the production of a dry meat additive is promising to increase functionality, stability in storage and transportation. The use of modern technology helps to get products with a high content of high quality protein, high quality of products and nutritional value.

The development of technology of meat products with a dry meat additive is associated with the involvement of different types and grades of meat, as well as combining it with plant fillers, the development of innovative methods of drying and packaging products aimed at increasing the consumer properties and hygienic quality of products.

According to the results of previous studies, namely the use of different methods of meat drying (sublimation, infra-red, lyophilic, microwave-vacuum drying, drying with combined heat approach, etc.), it was established that one of the ways of preserving meat protein in the native state is drying at low temperatures, namely, the use of microwavevacuum drying [16]. Such drying leads to the release of a large amount of heat, which is spent solely on the evaporation of moisture without heating the fabric of the product, and as a result evaporation can occur at a low temperature [1]. This contributes to intensive evaporation of moisture without significant change in the structure of the surface layer, reducing the duration of processing, preservation of biologically active components of raw materials, dying of microbial cells and inactivation of enzymes.

The purpose of this research was to investigate the functional and technological properties of the received protein compositions from poultry meat and to determine the optimum with high quality indices. 


\section{Materials and methods}

\section{Materials}

The following objects of research were used: meat of mechanical treatment, fillet, hams with skins, which were subjected to microwave-vacuum drying. The following comparisons were used foreign counterparts Mepro 85 (the Dutch manufacturer) - animal protein from cattle and Sunprotein (USA) - vegetable protein. [16, 18]. The drying was carried out at a temperature of not more than $37^{\circ} \mathrm{C}$ to obtain the required mass of condensate at constant stirring [6].

\section{Determination of moisture content}

The moisture content of the protein component was determined by drying the crushed sample at a temperature of $150^{\circ} \mathrm{C}$ for 1 hour. The mass fraction was determined as the difference between the weight of the drying unit (A1) and after drying (B) to the weight of the weight gain (A), expressed as a percentage:

$$
\mathrm{W}=\left(\mathrm{A}_{1}-\mathrm{B}\right) / \mathrm{A} \times 100
$$

\section{Determination of the number of MAOAM}

Determination of mesophilic aerobic and optional anaerobic microorganisms was carried out using a deep sowing method based on seeding of product dilutions into a dense nutrient medium.

At $1 \mathrm{cc}$. From each breeding place are put on the bottom of two sterile Petri cups, slightly opening them. Then, in each cup, pour 15-20 cubic centimeter of molten and cooled to $45{ }^{\circ} \mathrm{C}$ of nutrient agar with yeast extract and glucose are poured, then the cup is stirred along the surface of the table with circular motions [10]. After cooling the agar, the cups are placed in the thermostat upside down at $30{ }^{\circ} \mathrm{C}$ for 72 hours. Then the calculation of all types of colonies is conducted.

\section{Drying process}

The studies were carried out in a sealed reactor of a radio-transparent material (glass). Vacuum in the chamber is provided by a membrane vacuum pump. The reactor is placed in a chamber with a microwave energy source. The vapor volume of the chamber was communicated with the condenser where cold water circulated. Steam was converted into condensate, and the mass of condensate was determined by means of digital scales [16]. The moisture content of the raw material was established by the mass of the condensate. The temperature of the reactor was measured with a radiation pyrometer, and the pressure in the chamber was measured with a vacuum gauge. The consumed electric energy was determined with the help of a meter.

\section{Determination of water-absorbing ability}

The water-binding ability of meat was determined by the Grau and Hamma method. A weight of the mass of $0.3 \mathrm{~g}$, weighed to $0.0001 \mathrm{~g}$ precision on a polyethylene with a 
diameter of 55-60 mm is transferred to an ash-free filter, which is placed on a Plexiglas plate $100 \times 100 \mathrm{~mm}$ in size. The hard cover is covered with another plate of the same size and a load of $1 \mathrm{~kg}$ is placed on top. The pressing lasts for 10 minutes, after which the contour marks the spots around the pressed meat. The area is measured by a planimeter in cubic centimetres. The content of bound water in meat is calculated by the formula:

$$
\mathrm{V}=(\mathrm{A}-\mathrm{K} \times \mathrm{B}) / \mathrm{M} \times 100
$$

A-water content in weight, $\mathrm{mg} ; \mathrm{K}=8.4 \mathrm{mg}$; B- area of a wet spot, $\mathrm{cm}^{2}$, M-the mass of weight meat, $\mathrm{mg}$.

\section{Determination of water-retaining capacity}

The protein component is hydrated in distilled water at a ratio of 1: 5 for 1 hour, then it is placed in a thermostat with a temperature of $74-76^{\circ} \mathrm{C}$ and kept for 15 minutes. The contents of the glasses are transferred to centrifuge nets and centrifuged for 15 minutes at $1000 \mathrm{rpm}$ for separation of unbound water. It is calculated as the difference between the mass of the hydrated texture (Mr) and the mass of dry (Ms) to the mass of dry texture (Ms), expressed as a percentage:

$$
\mathrm{WRA}=(\mathrm{Mr}-\mathrm{Mc}) / \mathrm{Mc} \times 100
$$

\section{Determination of fat-retaining ability}

The protein component is dispersed in $10 \mathrm{~g}$ of vegetable oil and for $1 \mathrm{~h}$ at $20^{\circ} \mathrm{C}$, then placed in a thermostat with a temperature of $74-76{ }^{\circ} \mathrm{C}$ and kept for 15 minutes. The contents of the glasses are transferred to centrifuge mesh and centrifuged for 15 minutes at $1000 \mathrm{rpm}$. Calculated as the difference between the mass of the dispersing texture (Mr) and the mass of dry (Ms) to the mass of the dry texture (Ms), expressed as a percentage:

$$
\mathrm{FRA}=(\mathrm{Mr}-\mathrm{Mc}) / \mathrm{Mc} \times 100
$$

\section{Results and discussion}

\section{Determination of microbiological indicators}

Experimental studies were conducted with dry protein concentrate on the following indicators: microbiological, physico-chemical and sensory [7, 8].

The first point of control is the determination of the sanitary state of the powder after its preparation.

Microbiological contamination of the samples was determined before and after drying (Figure 1). According to the results of the obtained data, it was determined that the total number of microorganisms after drying in all samples did not exceed the norm for boiled dried meat $5 \times 10^{3}$, as well as no bacteria of the colon germ, pathogenic microorganisms, including the genus Salmonella, sulfitreducing clostridia were found. That is, dry meat additives comply with standard, do not exceed the permissible level and are safe for use in meat products. 


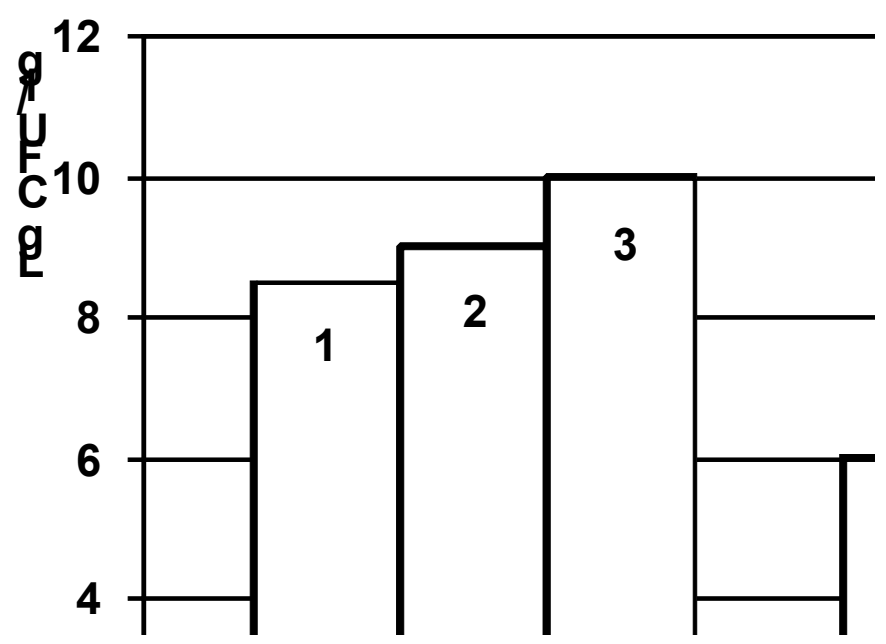

Figure 1. Lg colony-forming units/ $1 \mathrm{~g}$ protein component:

1 - Chicken Fillet, 2 - Chiken Ham, 3 - MMT, 4 - Sunprotein, 5 - Mepro 85, 6 Standard.

\section{Determination of functional and technological indicators}

The next stage of the research was the study of the functional and technological properties of all experimental samples namely: moisture content after drying, water-binding ability, water-retaining ability, fat-retaining ability and emulsion stability.

The result of determining the moisture content after drying in the samples studied is different, which is due to their composition and the effect of heat treatment in the drying stage, as well as the properties of raw materials [15].

At the mechanical action of high pressure on muscle fibers of poultry meat, there occurs a destruction of myofibrils with the release of myofibrillar proteins. This is accompanied by a rupture of electrostatic bonds and the formation of ionized groups that bind water [12].

On the basis of the data obtained, it can be concluded that the emergence of additional centers available in water after treatment by pressure, promotes the increase of moisture absorbing ability in poultry meat. 


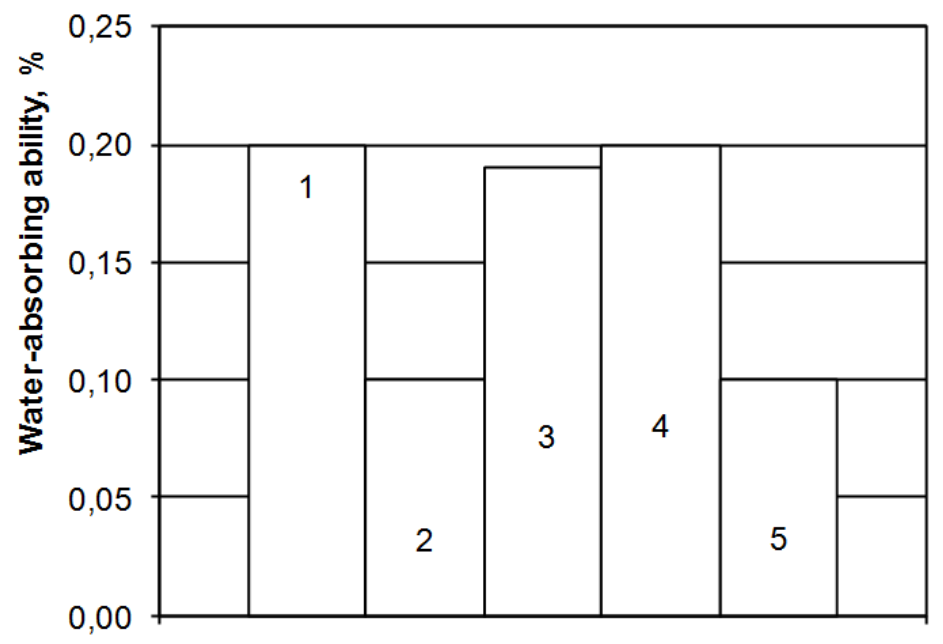

Figure 2. Moisture content of the protein component after drying: 1-Chicken Fillet, 2-Chiken Ham, 3-MMT, 4-Sunprotein, 5-Mepro 85.

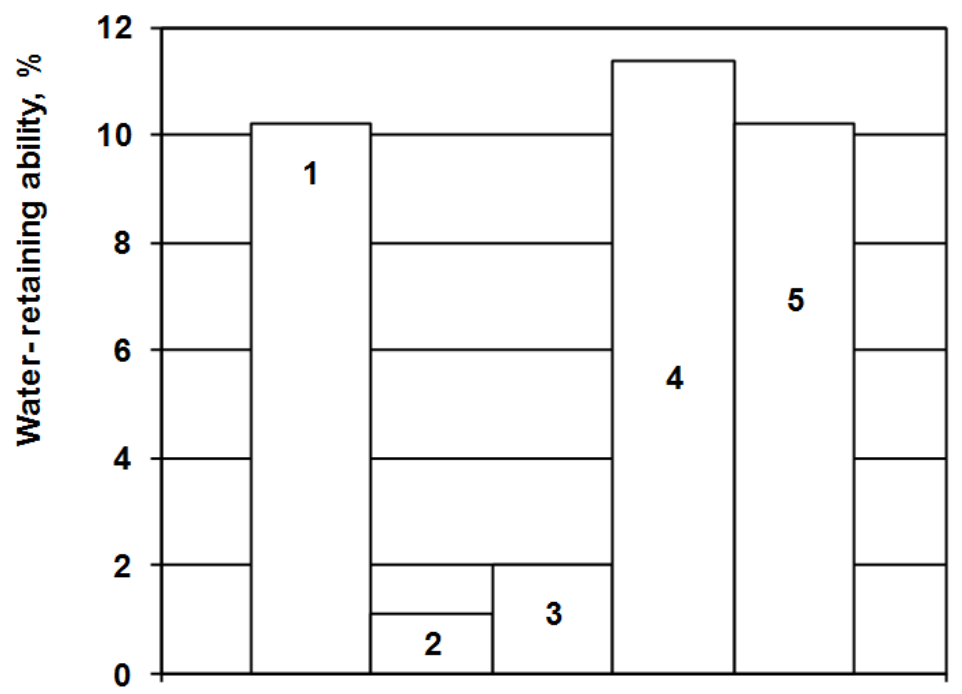

Figure 4. Content of water-retaining ability of the protein component after drying: 1 - Chicken Fillet, 2 - Chiken Ham, 3 - MMT, 4 - Sunprotein, 5 - Mepro 85. 


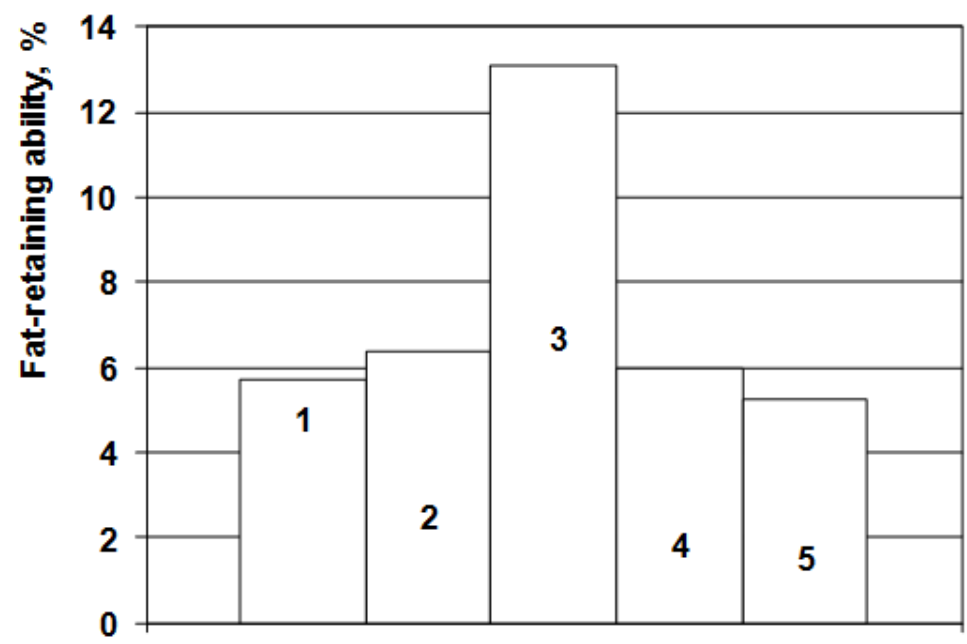

Figure 5. Content of fat - retaining ability of the protein component after drying: 1 - Chicken Fillet, 2 - Chiken Ham, 3 - MMT, 4 - Sunprotein, 5 - Mepro 85.

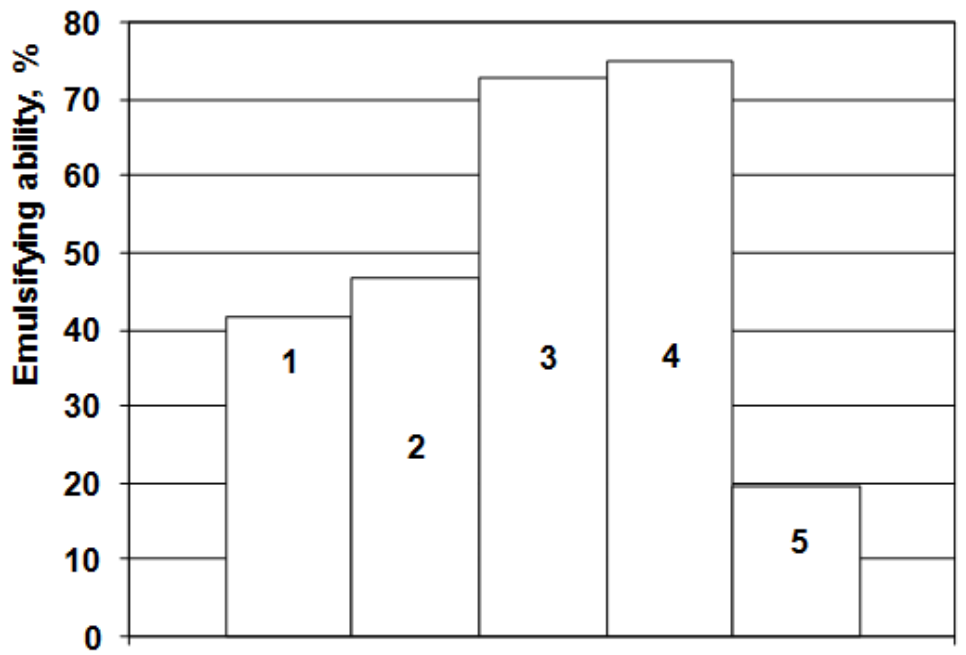

Figure 6. Content of emulsifying ability of the protein component after drying: 1 - Chicken Fillet, 2 - Chiken Ham, 3 - MMT, 4 - Sunprotein, 5 - Mepro 85.

The value of water-retaining, fat-retaining and emulsifying ability in the samples varies, due to their composition and the effect of heat treatment in the drying stage. Comparing all the studied samples of meat supplements studied as protein filler, we see that the highest results were found in chicken fillet and meat of mechanical processing, the lowest observed in chicken ham [14]. 


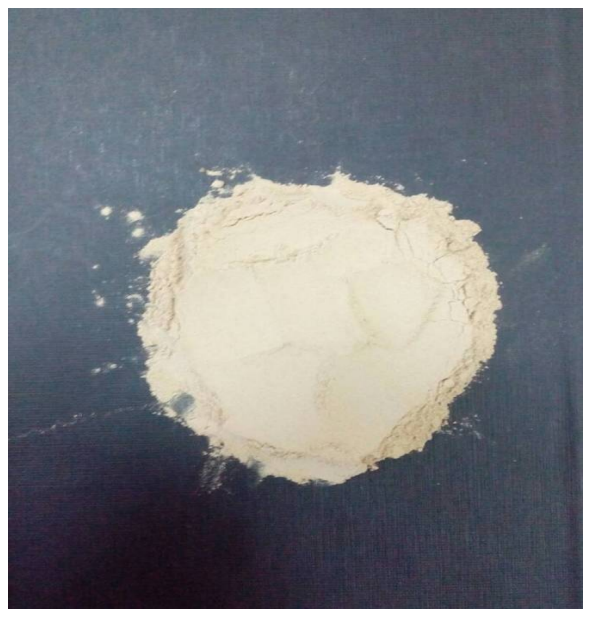

$a$

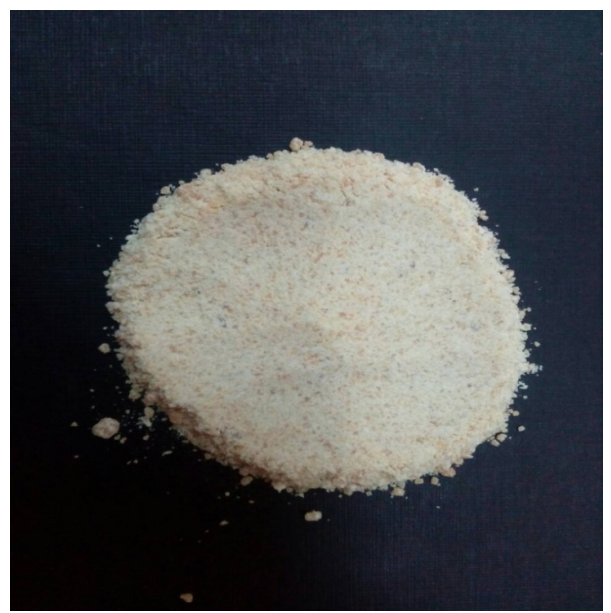

b

Figure 7. The samples of the protein component after drying: a- MMT, b- Sunprotein
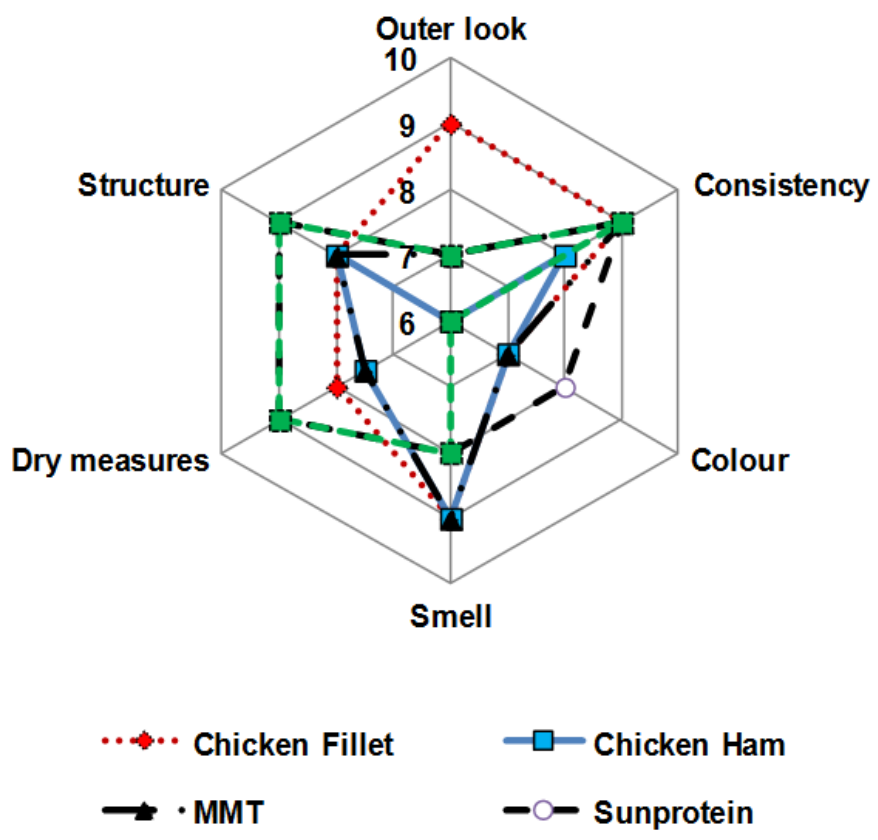

Figure 7. Profilogram of the studied meat additives 
According to the sensory evaluation, model meat supplements were characterized by high sensory characteristics [2]. Loose consistency, inherent in dry powders, homogeneous color, like meat, pleasant scent. The best sensory properties were found in chicken fillet, mechanical collapse meat and sunprotein, the lowest rates were observed in the chicken ham.

\section{Conclusion}

1. Based on the analysis of existing technologies for the production of protein supplements from various anatomical parts of poultry meat, the technology of dry additives with the use of electromagnetic energy sources of ultrahigh frequency under vacuum was developed.

2. In work was investigated of efficient use of meat additives in meat products is investigated, to compare different samples according to microbiological, physicalchemical and functional-technological indicators.

3. It is shown that the highest rates were observed in dry powders of chicken fillet and mechanically-processed meat, which will bring the finished product closer to a product with a balanced composition, high quality and nutritional value.

4. Based on the results obtained and from an economic point of view it is more appropriate to use dry powder from mechanical collapse meat.

5. It has been experimentally established that the protein composition of animal origin obtained by the proposed method meets the existing technological regulations.

Regulation EU No. 178/2002 requires enterprises to identify from whom raw materials and ingredients and have a traceability system and procedures that allow them to quickly obtain the necessary information. As a result, the use of the developed additive allows you to create meat products controlled by origin.

\section{References}

1. Alessandro Lana, Lello Zolla (2016), Proteolysis in meat tenderization from the point of view of each single protein: A proteomic perspective, Journal of Proteomics, 147, pp. 85-97.

2. Tornberg E. (2005), Effects of heat on meat proteins - Implications on structure and quality of meat products, Meat Science, 70(3), pp. 493-508.

3. Lofgren P.A. (2013), Meat, Poultry, and Meat Products: Nutritional Value, Reference Module in Biomedical Sciences, pp. 160-167.

4. Tarte R. (2011), Meat protein ingredients, Handbook of Food Proteins, pp. 56-91.

5. Hayes J., Brunton N. (2011), The use of nutraceuticals in processed meat products and their effects on product quality, safety and acceptability, Processed Meats: Improving Safety, Nutrition and Quality, pp. 372-402.

6. Pattra Laopoolkit, Prisana Suwannaporn (2011), Effect of pretreatments and vacuum drying on instant dried pork process optimization, Meat Science, 88(3), pp. 553-558.

7. Dolores Garrido, Macarena Egea, Belen Linares, etc., (2017), Sensory characteristics of meat and meat products from entire male pigs, Meat Science, 129, pp. 50-53.

8. Benjamin M., (2017), Review: Nutrient density and nutritional value of meat products and non-meat foods high in protein, Trends in Food Science \& Technology, 65, pp.103-112. 
9. Vinnikova L.G. (2006), Tekhnologiia miasa i miasoproduktov, Firma «Inkos», Kyiv.

10. Antipova L.V. (2001), Metody issledovaniia miasa i miasnykh produktov, Kolos, Moscow.

11. Polianskaia S.V. (2013), Kompleksnyi podkhod $k$ pererabotke ptitsy, Miasnaia industriia, Moscow.

12. Probst Y. (2009), Nutrient Composition of Chicken Meat, Rural Industries Research and Development Corporation, Australia, p.75.

13. Pasichnyi V.N. (2004), Tekhnologiia proizvodstva gidratirovannykh beloksoderzhashchikh napolnitelei farshevykh sistem, Miasnoi biznes, 7, pp. 18-21.

14. Pasichnyi V.N. (2004), Tekhnologiia proizvodstva gidratirovannykh beloksoderzhashchikh napolnitelei farshevykh sistem, Miasnoi biznes, № 8, pp. 1215 .

15. Donskova L.A. (2004), Pishchevye dobavki v miasnoi industrii: identifikatsiia opasnostei i skriningovyi analiz riska, Upravlene, 3, p. 49.

16. Burdo O.G., Burdo A.K., Sirotyuk I.V., Pour D.R. (2017), Technologies of Selective Energy Supply at Evaporation of Food Solutes, Regional Energetic Problems, Kishinev, 1(33), p.100.

17. Gizburg A.S. (1973), Osnovy teorii i tekhniki sushki pishchevykh produktov, Pishchevaia promyshlennost, Moscow, p. 527.

18. Stankevich G.N. (2006), Raschet prodolzhitelnosti sushki po uravneniiam kinetiki s uchetom konstruktivnykh osobennostei sushilok, Naukovi pratsi ONAPT, 28(2), pp. $14-20$. 


\title{
Identification, characterization and industrial utilization of autochthonous strains of Streptococcus thermophilus isolated from Moldavian raw milk and dairy products of spontaneous fermentation
}

\author{
Anatoli Cartasev \\ Scientific and Practical Institute of Horticulture and Food Technology, Chisinau, \\ Republic of Moldova
}

Keywords:

Streptococcus

thermophilus

Молоко

Fermentation

Identification

\section{Article history:}

Received

29.06.2018

Received in

revised form

20.09.2018

Accepted

28.09.2018

\section{Corresponding} author:

Anatoli Cartasev

E-mail:

anatoli.cartasev@

imb.asm.md

DOI:

$10.24263 / 2304-$

974X-2018-7-3-10

\section{Abstract}

Introduction. Lactic acid bacteria with known metabolic properties contribute to the sensory characteristics of the products, to their quality and safety. The limited number of highly biotechnologically available strains and the constant risk of bacteriophage attacks justify the continued searching for new strains.

Materials and methods. Identification of thermophilic lactic acid bacteria was performant on the basis of phenotypic properties and using molecular methods - RAPD-PCR and FTIR spectroscopy. Antagonistic activity of selected strains was carried out by diffusion method. Starter culture and samples of yoghurt were manufactured according to the traditional technology.

Results and discussion. Selected strains of S. thermophilus are characterized by intense acidification of the milk for 3-4 hours, developing a milk acidity between $65-74{ }^{\circ} \mathrm{T}$, forming a homogeneous, compact, dense coagulum, which ensures its firm consistency. The strains S. thermophilus strains CNMN-LB-50 and CNMN-LB-51 are capable of synthesizing exopolysaccharides (EPS).

The antagonistic activity against pathogenic microorganisms of strains of is high. The inhibition range varies between 16 and $18 \mathrm{~mm}$ from Escherichia coli. and $19-21 \mathrm{~mm}$ to Staphylococcus aureus, which inhibits the development of intestinal infections and prevents the development of pathogens in fermented milk samples. The maximum yeld of EPS synthesized at suboptimal temperature of $32{ }^{\circ} \mathrm{C}$ is $19.4 \%$ higher than at the optimal temperature for this process $\left(40{ }^{\circ} \mathrm{C}\right)$ for $\mathrm{S}$. thermophilus CNMN-LB-50 strain and 23, $8 \%$ for S. thermophilus CNMN-LB-51 strain. To stimulate the synthesis of EPS under industrial conditions in the manufacture of fermented milk products without altering the temperature, the nutrient medium should be supplemented with sucrose in an amount of $8 \%$.

Conclusions. It is possible obtaining from the microflora of raw milk and dairy products of spontaneous fermentation the autochthonous strains of lactic bacteria with valuable biotechnological properties, intended for use in the composition of starter cultures for the production of fermented milk products. 


\section{Introduction}

At the present, technological processes based on the activity of lactic acid bacteria (LAB) have a special significance. Modern dairy production is closely linked to the search and selection of suitable LAB with the specific properties, which implies an increase in the diversity of fermented dairy products. Thermophilic and mesophilic LAB are the most widely used as starter cultures for the production of fermented dairy products. The specific taste, consistency and other properties of the fermented dairy products depend on the strains which starter culture made up. The thermophilic LAB are capable to grow at temperatures of $37-45{ }^{\circ} \mathrm{C}$ that is an important condition associated with the technological process of manufacturing fermented dairy products such as yoghurt, baked fermented milk and various cheeses and play an important functional role in fermented dairy products [1].

Thermophilic cocci strains isolated from raw milk and spontaneous fermentation dairy products, in most cases, belong to Streptococcus and Enterococcus genera. Thermophilic LAB S. thermophilus are "useful" representatives for their application in starter cultures [2].

Identification process of an isolated strain includes its complete description and comparison with a reference strain. The rapid and specific classification of bacteria is an important task in microbiology, which can be achieved using traditional methods based on physiological, biochemical and molecular methods.

However, many scientists notice difficulties in differentiating and identifying of Streptococcus and Enterococcus bacteria using only the phenotype classification methods describing the inadequacy of the classical phenotype characteristics of these genes, such as the ability to grow on a medium containing esculin, bile and sugar fermentation, antibiotic resistance, and the range of typical growth temperature [3-5].

The aim of the present study was isolation and identification of S. thermophilus strains from raw milk and spontaneous fermentation dairy products and to study their industrial potential in order to create starter cultures which are suitable to yogurt production in local conditions.

\section{Materials and methods}

\section{Reference bacterial strains}

The following strains Streptococcus thermophilus A737 was obtained from Czech Collection of Microorganisms (Brno, Czech Republic), Streptococcus thermophilus 1241, Lactobacillus casei 4791were obtained from Collection of Microorganisms (Food Research Institute, Bratislava, Slovakia).

\section{Isolation}

10 grams of samples were homogenized with $90 \mathrm{ml}$ sterile peptone physiological saline solution ( $5 \mathrm{~g}$ peptone, $8.5 \mathrm{~g} \mathrm{NaCl}$, up to $1000 \mathrm{ml}$ distilled water, $\mathrm{pH}$ 7.0). The homogenate was diluted serially and the appropriate dilutions were surface plated on M17 agar media (Merck, Darmstadt, Germany), then plates were incubated at $37^{\circ} \mathrm{C}$ for 72 hours.

\section{Physiological and biochemical tests}

Morphology. Pure cultures grown in skimmed milk in an incubator at $37{ }^{\circ} \mathrm{C}$ for $18 \mathrm{~h}$ was used. Before a microscope examination smears of cultures were stained with methylene blue for a few minutes. 
Production of $\mathrm{CO}_{2} .10 \mathrm{ml}$ of M17 broth culture of the test strain incubated at $37^{\circ} \mathrm{C}$ for $18 \mathrm{~h}$ covered the surface of the broth by molten overlay agar, precooled to $47^{\circ} \mathrm{C} \pm 1^{\circ} \mathrm{C}$, to a depth of $1 \mathrm{~cm}$. Cultures were incubated for 1 week at $37^{\circ} \mathrm{C}$. The presence of gas is evident when the agar layer detaches itself from the underlying contents.

Catalase reaction. Mixed equal volumes of the M17 broth culture, incubated set at 37 ${ }^{\circ} \mathrm{C}$ for $18 \mathrm{~h}$, with $150 \mathrm{~g} \cdot \mathrm{l}^{-1}$ hydrogen peroxide in a tube fitted with a rubber stopper. Gently turn the tube upside down once to favour mixing, and observe for bubbles of oxygen forming in the broth at room temperature over $20 \mathrm{~min}$.

Action in litmus milk. In $10 \mathrm{ml}$ of litmus milk ( $70 \mathrm{~g}$ litmus in $1000 \mathrm{~mL}$ skimmed milk) was introduced a loop of studied culture. Litmus milk acidified by S. thermophilus turns pink and then coagulates. After coagulation the colour remains pink due to very slow and often incomplete reduction of litmus, with a more intensely coloured upper ring.

Thermoresistance. Into $5 \mathrm{ml}$ of skimmed milk by loop was introduced studied strain, incubated set at $37^{\circ} \mathrm{C}$ for $4 \mathrm{~h}$. After, the tubes were placed in the water bath at temperature of $60{ }^{\circ} \mathrm{C}$ for 30 minutes, and then cooled. Finally, the samples were incubated at $37^{\circ} \mathrm{C}$ for $24 \mathrm{~h}$. Acidified or coagulated milk means thermoresistance of studied strains.

Growth in the presence of sodium chloride. Inoculated tubes containing M17 broth with $20 \mathrm{~g} \cdot 1^{-1}$ and $40 \mathrm{~g} \cdot 1^{-1} \mathrm{NaCl}$ incubated for 7 days at $37{ }^{\circ} \mathrm{C}$. Presence of turbidity in the tube indicates the culture growth.

Growth in the presence of methylene blue. Inoculated skim milk supplemented with 0.1 $\mathrm{g} \cdot 1^{-1}$ and $1.0 \mathrm{~g} \cdot 1^{-1}$ of methylene blue solution were incubated at $37^{\circ} \mathrm{C}$. Coagulation or its absence was visually determined at 12,24 and $48 \mathrm{~h}$. for $48 \mathrm{~h}$. S. thermophilus does not grow in presence of methylene blue.

Growth at pH 9.6 was observed after $48 \mathrm{~h}$ of incubation at $37{ }^{\circ} \mathrm{C}$ in M17 broth which $\mathrm{pH}$ was adjusted to 9.6 .

Isolation of EPS. $100 \mathrm{ml}$ of yoghurt were centrifuged at $837 \mathrm{rad} \cdot \mathrm{s}^{-1}$ for $10 \mathrm{~min}$ and 17 $\mathrm{ml}$ of trichloracetic acid (Chimprom, Ukraine) were added to each sample. Samples were cooled up to $4^{\circ} \mathrm{C}$ and again centrifuged at $837 \mathrm{rad} \cdot \mathrm{s}^{-1}$ for $10 \mathrm{~min}$. Precipitation of EPS from samples was provided using cold ethanol (1:3). The samples were kept in the fridge for $24 \mathrm{~h}$ and then centrifuged $\left(40^{\circ} \mathrm{C}, 837 \mathrm{rad} \cdot \mathrm{s}^{-1}\right.$, for $\left.10 \mathrm{~min}\right)$.

\section{(GTG) $)_{5}$-PCR fingerprinting}

Total genomic DNA was extracted from the colony material of each strain after incubating them for $24 \mathrm{~h}$ in M17 broth (Merck, Darmstadt, Germany) at $37^{\circ} \mathrm{C}$. DNA was extracted from $1 \mathrm{ml}$ of the broth centrifuged at $5000 \times \mathrm{g}$ for $10 \mathrm{~min}$. A loop of culture was transferred to $1 \mathrm{ml}$ of distilled water, mixed and centrifuged at $10000 \cdot \mathrm{g}$ for $5 \mathrm{~min}$. InstaGene suspension (Bio-Rad, Hercules, California, USA) was added to the sediment and incubated at $56{ }^{\circ} \mathrm{C}$ for $25 \mathrm{~min}$. Then the mixture was vortexed, incubated at $100{ }^{\circ} \mathrm{C}$ for 8 min, vortexed, centrifuged at $10000 \times \mathrm{g}$ for $5 \mathrm{~min}$ and the supernatant containing DNA was removed. A volume of $2 \mu \mathrm{l}$ of the DNA solution was added to the Polymerase Cain Reaction (PCR) reaction mixture (total volume, $25 \mu \mathrm{l}$ ) containing $10000 \mathrm{nmol} \cdot \mathrm{l}^{-1}(\mathrm{GTG})_{5}$ primer (5'-GTG GTG GTG GTG GTG-3') synthesized by Qiagen (Hilden, Germany), 600 $\mu \mathrm{mol} \cdot \cdot^{-1} \mathrm{dNTP}$ (Applied Biosystems, Foster City, California, USA), $1.5 \mu \mathrm{mol} \cdot \mathrm{l}^{-1} \mathrm{MgCl}_{2}, 1.5$ U HotStarTaq DNA polymerase (Qiagen) and $2.5 \mu \mathrm{l}$ of $10 \times$ concentrated PCR buffer supplied with the polymerase. PCR was carried out in a Biometra Personal thermal cycler (Whatman Biometra, Göttingen, Germany) using a thermal programmeconsisting of the initial denaturation at $95{ }^{\circ} \mathrm{C}$ for $15 \mathrm{~min}, 30$ cycles of denaturation at $95{ }^{\circ} \mathrm{C}$ for $60 \mathrm{~s}$, annealing at $40{ }^{\circ} \mathrm{C}$ for $90 \mathrm{~s}$, ramping at $0.1^{\circ} \mathrm{C} \cdot \mathrm{s}^{-1}$, and polymerization at $72{ }^{\circ} \mathrm{C}$ for $120 \mathrm{~s}$, followed by the final polymerization at $72{ }^{\circ} \mathrm{C}$ for $10 \mathrm{~min}$. A volume of $12 \mu \mathrm{l}$ of the PCR 
product was mixed with $1.5 \mu \mathrm{l}$ of the loading buffer and analyzed by electrophoresis in a $1.5 \%$ agarose gel Seakem LE (FMC Bioproducts, Rockland, Maine, USA) for $5 \mathrm{~h}$ at 2.3 $\mathrm{V} \cdot \mathrm{cm}^{-1}$. Molecular size standard $\mathrm{n} \times 250 \mathrm{bp}$ (Invitrogen, Carlsbad, California, USA) was electrophoresed in every fourth lane along with samples. The gel was stained with ethidium bromide for $30 \mathrm{~min}$, destained in distilled water for $5 \mathrm{~min}$, visualized under UV light and photographed with a digital camera. Rep-PCR profiles were compared with reference strains from culture collections.

\section{Sample preparation for FTIR spectroscopy}

S. thermophilus strains were cultured in pure cultures in M17 medium for $24 \mathrm{~h}$ at 37 ${ }^{\circ} \mathrm{C}$. The cultures were decimally diluted with $0.9 \% \mathrm{NaCl}$ and binary mixtures were prepared from the dilution $10^{-4}$. A volume of $0.2 \mathrm{ml}$ of the mixture was streaked on M17 agar and the plates were cultured for $72 \mathrm{~h}$ at $37^{\circ} \mathrm{C}$. Colonieswere picked directly from the plate by an inoculation loop, based on visual evaluation of colony morphology, and each was suspended in $100 \mu \mathrm{l}$ of distilled water. The suspension containing whole cells was mixed by vortexing for $1 \mathrm{~min}$ and $35 \mu \mathrm{l}$ of the suspension was pipetted on a position on a 96-position $\mathrm{Zn}-\mathrm{Se}$ plate. The plate was dried for $45 \mathrm{~min}$ at $37^{\circ} \mathrm{C}$ and immediately measured by Fourier transform infrared (FTIR) spectroscopy.

\section{FTIR spectroscopy}

A Bruker Tensor 27 FTIR spectrometer quipped with HTS-XT module (Bruker Billerica, Massachusetts, USA) was used. The spectrawere recorded in a range from 4000 $\mathrm{cm}^{-1}$ to $400 \mathrm{~cm}^{-1}$, with spectral resolution of $4 \mathrm{~cm}^{-1}$ and 32 scans per sample. The spectra were processed by OPUS software (Bruker Billerica, Massachusetts, USA), which involved averaging of 32 scans, calculation of first derivative by Savitzky-Golay algorithm with 9 smoothing points, and vector-normalization in the region from $1780 \mathrm{~cm}^{-1}$ to $720 \mathrm{~cm}^{-1}$. Cluster analysis was carried out by OPUS software on the basis of Euclidean distances using Ward's algorithm, heterogeneities being assigned values from 0 to 2 .

\section{Strains employed}

Six single-strain cultures were used for starter culture formation: EPS-producing Streptococcus thermophilus LB-50 and Streptococcus thermophilus LB-51, non-EPS Streptococcus thermophilus LB-52, Streptococcus thermophilus LB-53, Streptococcus thermophilus LB-54 and Lactobacillus delbrueckii ssp. bulgaricus LB-42 belonging to the National Collection of Non-Pathogenic Microorganisms of the Institute of Microbiology and Biotechnology (CNMN IMB), previously selected from raw milk. The selected strains were propagated three times consecutively using $0.1 \%$ inoculum volume in $10 \%$ reconstituted skim milk (InLac, Republic of Moldova) at $40^{\circ} \mathrm{C}$ until coagulation. Working strains (pure culture $10 \mathrm{~mL}$ ) were gradually associated by inserting into $30 \mathrm{~mL}$ of sterile skim milk and incubated at $40^{\circ} \mathrm{C}$ until coagulation ( $\left.\mathrm{pH} 4.6\right)$. Three mixed-strain starter cultures were used to make yoghurt samples for studying the influence of the EPS on the quality of the final product as follows: two EPS-starter culture consists of $S$. thermophilus CNMN-LB-50, CNMN-LB-51 și Lb. bulgaricus CNMN-LB-42; S. thermophilus CNMNLB-50, CNMN-LB-52 și Lb. bulgaricus CNMN-LB-42 non-EPS starter culture - $S$. thermophilus CNMN-LB-52, CNMN-LB-53, CNMN-LB-54 şi Lb. bulgaricus CNMN-LB42. Non-EPS starter culture served as control.

\section{Yoghurt production}

Samples of yoghurt were manufactured under industrial conditions using milk produced by JLC Group (Chisinau, Republic of Moldova). The milk was pasteurized at 
$71^{\circ} \mathrm{C}$ during $15 \mathrm{~s}$ and cooled down to $40^{\circ} \mathrm{C}$. Two samples of yoghurt were produced: sample 1 using EPS-producing starter culture and sample 2 with non-EPS starter culture. Samples of yoghurt were incubated at $37^{\circ} \mathrm{C}$ until $\mathrm{pH}$ decreased to a value of 4.5 , then kept at $4^{\circ} \mathrm{C}$.

Milk acidification. To $10 \mathrm{ml}$ of milk clot was added $20 \mathrm{ml}$ of distillate water, 3 drops of phenolphthalein solution and agitated. Then titrated with a $0.1 \mathrm{~mol} \cdot \mathrm{l}^{-1}$ sodium hydroxide solution till the solution has been turned to pink. $1 \mathrm{ml}$ of $0.1 \mathrm{~mol} \cdot \mathrm{l}^{-1}$ sodium hydroxide standard solution correspond to $0.009 \mathrm{~g}$ lactic acid.

Enumenarion of the total viable count of LAB was performend using standard pour plate technique. S. thermophilus and L. delbrueckii subsp. bulgaricus were incubated aerobically at $37{ }^{\circ} \mathrm{C}$ for $48 \mathrm{~h}$. The total counts were expressed as $\log 10 \mathrm{CFU} \cdot \mathrm{g}^{-1}$ of the product.

Antimicrobial activity of selected strains was performed by using disc diffusion method. As the test-culture were used Staphilococcus aureus ATCC® 25932 ${ }^{\mathrm{TM}}$, Escherichia coli ATCC ${ }^{\circledR} 25922^{\mathrm{TM}}$. Five sterile paper blank discs were placed on the agar plate which was inoculated by indicator strains and the filtered supernatant of $S$. thermophilus strains were applied on the surface of each discs. Plates were incubated at $37^{\circ} \mathrm{C}$ and zones of inhibition were observed. The inhibition zone was expressed in millimeters.

The viscosity of yoghurt samples was studied with a digital rheometer DV-III (BROOKFIELD, Canada) using the Rheocalc 32 software. Measurements were performed at different rotation speeds up to $21 \mathrm{rad} \cdot \mathrm{s}^{-1}$. The viscosity measurement was carried out at a temperature of $25^{\circ} \mathrm{C}$.

\section{Statistical analysis}

Data were expressed as means \pm standard deviations for triplicate determination. Statistical analysis was performed using Microsoft Excel 2007. Differences were considered to be significant at validity of $\alpha=0.95$.

\section{Results and discussion}

The LAB selection for their use as starter cultures includes the strains isolation from natural sources and study of their properties, which determines the industrial value.

Milk is the most complete medium for selecting LAB. The use of sterile skimmed milk as a culture medium is more favorable for the growing of $\mathrm{S}$. thermophilus. Thus, natural selection of industrial valuable strains occurs.

The Streptococcus thermophilus strains were isolated from cow's raw milk and spontaneous fermentation dairy product samples collected from local markets in different regions of the Republic of Moldova. Approximately 300 samples were studied for isolation of S. thermophilus

S. thermophilus, according to Bergey's Manual [7], are capable of developing at temperature between $42-45{ }^{\circ} \mathrm{C}$. Though, the optimal growth is between $37-40{ }^{\circ} \mathrm{C}$. Therefore all samples were cultivated at $37^{\circ} \mathrm{C}$. At the final of the routine examination of colony morphology and microscopy were selected 5 typical strains S. thermophilus for further research.

The 5 selected isolates were initially examined using morphological and biochemical tests (Table 1) and were classified as cocci growing in chains. 
All isolates were able to grow at $20 \mathrm{~g} \cdot \mathrm{l}^{-1}$ of $\mathrm{NaCl}$ content and at $0.1 \mathrm{~g} \cdot \mathrm{l}^{-1}$ of methyleneblue in M17 broth. In litmus milk acidified by isolates were observed coagulation and reduction of pink colour. In additional 5 isolates fermented the lactose, saccharose, glucose and not fermented esculine. It is well known that S. thermophilus possesses a high ability to grow in a medium supplemented by lactose, glucose and saccharose $[8,9]$. Inability to ferment esculine, high sensibility to $40 \mathrm{~g} \cdot \mathrm{l}^{-1}$ of $\mathrm{NaCl}$ content and lack of grow in $1 \mathrm{~g} \cdot \mathrm{l}^{-1}$ of methylene-blue distinguishes S.thermophilus species from Enterococcus genera [10]. According to the obtained results of morphological and biochemical tests the 5 isolates were identified as S. thermophilus.

Table 2

\section{Morphological and biochemical characterization of selected isolates}

\begin{tabular}{|c|c|c|c|c|c|}
\hline \multirow[b]{2}{*}{ Characteristics } & \multicolumn{5}{|c|}{ Code of isolates } \\
\hline & $\begin{array}{c}\text { CNMN- } \\
\text { LB-50 }\end{array}$ & $\begin{array}{l}\text { CNMN- } \\
\text { LB-51 }\end{array}$ & $\begin{array}{l}\text { CNMN- } \\
\text { LB-52 }\end{array}$ & $\begin{array}{l}\text { CNMN- } \\
\text { LB-53 }\end{array}$ & $\begin{array}{l}\text { CNMN- } \\
\text { LB-54 }\end{array}$ \\
\hline Cell morphology & \multicolumn{5}{|c|}{ Cocci in long chains } \\
\hline Gram staining & + & + & + & + & + \\
\hline $\begin{array}{l}\text { Production of gas } \\
\left(\mathrm{CO}_{2}\right)\end{array}$ & - & - & - & - & - \\
\hline Catalase production & - & - & - & - & - \\
\hline $\begin{array}{l}\text { Action in litmus } \\
\text { milk }\end{array}$ & $\mathrm{ACR}$ & ACR & $\mathrm{ACR}$ & ACR & ACR \\
\hline Thermoresistance & + & + & + & + & + \\
\hline \multicolumn{6}{|l|}{ Growth in presence of } \\
\hline $\mathrm{NaCl} 20\left[\mathrm{~g} \cdot \mathrm{l}^{-1}\right]$ & + & + & + & + & + \\
\hline $\mathrm{NaCl} 40\left[\mathrm{~g} \cdot \mathrm{l}^{-1}\right]$ & - & - & - & - & - \\
\hline $\begin{array}{l}\text { methylene blue } 0.1 \\
{\left[\mathrm{~g} \cdot 1^{-1}\right]}\end{array}$ & + & + & + & + & + \\
\hline $\begin{array}{l}\text { methylene blue } 1.0 \\
{\left[\mathrm{~g} \cdot \mathrm{l}^{-1}\right]}\end{array}$ & - & - & - & - & - \\
\hline $\mathrm{pH} 9.2$ & - & - & - & - & - \\
\hline Glucose & + & + & + & + & + \\
\hline Lactose & + & + & + & + & + \\
\hline Sucrose & + & + & + & + & + \\
\hline Galactose & - & - & - & - & - \\
\hline Maltose & - & - & - & - & - \\
\hline Ramnose & - & - & - & - & - \\
\hline Manose & - & - & - & - & - \\
\hline Sorbita & - & - & - & - & - \\
\hline Esculin & - & - & - & - & - \\
\hline Xilose & - & - & - & - & - \\
\hline
\end{tabular}

$+=$ positive, $-=$ negative

ACR - acidification, coagulation, reduction, Thermoresistance - growth after heating for $30 \mathrm{~min}$ at temperature $60^{\circ} \mathrm{C}$. 
The PCR product visualization of $(\mathrm{GTG})_{5}$ PCR fingerprints are presented in Figure 1.

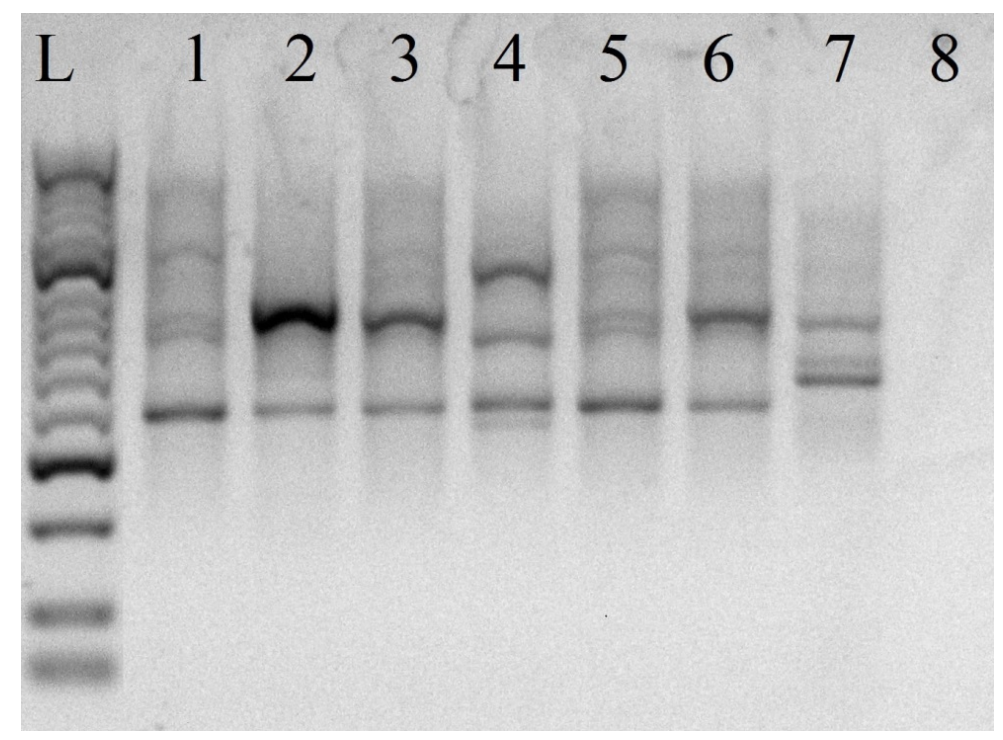

Figure 1. PCR products for S.thermophilus isolates

L - HipperLadder 50 bp; 1 -S. thermophilus CNMN-LB-52; 2 - S. thermophilus CNMN-LB-50; 3 - S. thermophilus CNMN-LB-51; 4 - reference strain S. thermophilusA737; 5 -S. thermophilus CNMN-LB-54; 6 - S. thermophilus CNMN-LB-53; 7 - positive control (S. thermophilus 1241);

8 - negative control

DNA fragments were yielded 2 to 7 bands. The results confirmed that the similarity level of the genes of the studied strains was $99 \%$ with the reference strains of $S$. thermophilus.

The FTIR spectra of the 5 isolates were compared with the reference strain $S$. thermophilus A737. The Pearson product-moment correlation coefficient was applied to the studied strains across the spectra region from $4000 \mathrm{~cm}^{-1}$ to $500 \mathrm{~cm}^{-1}$ [11]. Naumann established that the highest strain correlation is reached at the following intervals: from $3000 \mathrm{~cm}^{-1}$ to $2800 \mathrm{~cm}^{-1}, 1500 \mathrm{~cm}^{-1}$ to $1400 \mathrm{~cm}^{-1}$ and $900 \mathrm{~cm}^{-1}$ to $700 \mathrm{~cm}^{-1}$ [12]. According to this study, the correlation of 5 isolates showed $99 \%$ similarity with reference strain.

After isolation and identification all 5 isolates of $S$. thermophilus were deposited at National Collection of Non-pathogenic Microorganisms of Institute of Microbiology and Biotechnology (CNMN IMB).

The next step of our study was determination of technological properties of the selected strains and their suitability for use as starter cultures. The fermentative activity of lactic bacteria is the most important technological criteria for the appreciation of their use in dairy industry. The intensification of the milk fermentation process and improvement of dairy products quality can be achieved by using biochemically active LAB strains.

The evolution of acidification was monitored for all selected S. thermophilus strains, as shown in Figure 2. 


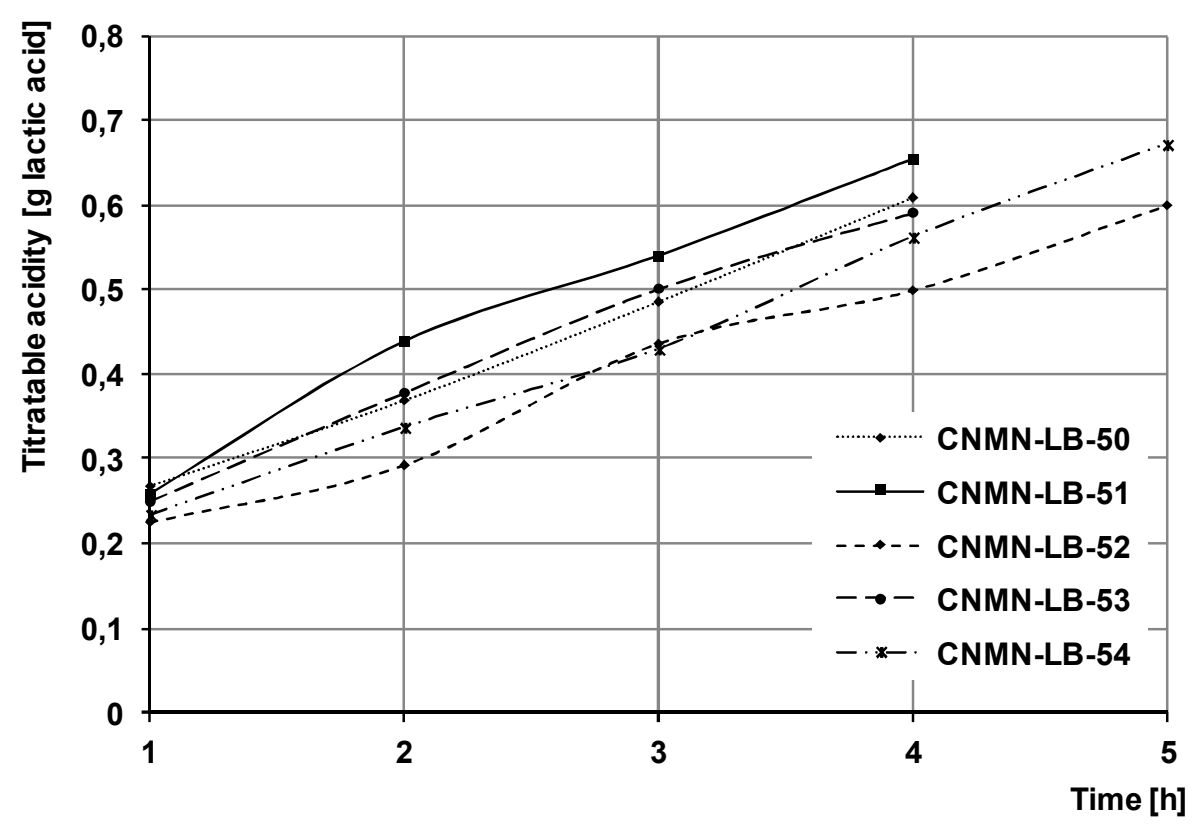

Figure 2. Kinetics of titratable acidity of the $S$. thermophilus strains in milk

Data shows that the selected strains of S.thermophilus has a high speed of the milk acidification for 5 hours. The selected strains had a different capacity of lactose fermentation. $S$. thermophilus CNMN-LB-50, CNMN-LB-51, CNMN-LB-53 coagulate skim milk in a $4 \pm 0.5 \mathrm{~h}, S$. thermophilus CNMN-LB-52 and CNMN-LB-54 in $5 \pm 0.5 \mathrm{~h}$.

The strain of $S$. thermophilus along with $L b$. bulgaricus are used as starter culture for yoghurt production. The main pathogens in the dairy industry are Escherichia coli, Staphylococcus aureus, Clostridium botulinum, Listeria monocytogenes. These spoilage bacteria are capable to survive during a production process. E. coli and S. aureus in dairy products result from post-pasteurization contamination [13]. Therefore, one of the basic parameters for technological interest of LAB selection is their antimicrobial activity. The antimicrobial activity against E. coli ATCC 25922 and S. aureus ATCC 25923 of 5 selected S. thermophilus strains were investigated using the agar-discdiffusion method [14] (table 2).

Table 2

Antagonism of $E$. coli and $S$. aureus by $S$. thermophilus isolates using agar-disc diffusion method

\begin{tabular}{|l|l|l|}
\hline \multirow{2}{*}{ Code of strain } & \multicolumn{1}{|c|}{ Escherichia coli } & Staphylococcus aureus \\
\cline { 2 - 3 } & \multicolumn{2}{|c|}{ Zone of inhibition [mm] } \\
\hline CNMN LB-50 & $16 \pm 0.5$ & $20 \pm 0.5$ \\
\hline CNMN LB-51 & $18 \pm 0.3$ & $20 \pm 0.3$ \\
\hline CNMN LB-52 & $17 \pm 0.2$ & $19 \pm 0.3$ \\
\hline CNMN LB-53 & $16 \pm 0.2$ & $19 \pm 0.2$ \\
\hline CNMN LB-54 & $17 \pm 0.5$ & $21 \pm 0.5$ \\
\hline
\end{tabular}


Based on the results, a total of 5 analyzed strains of S. thermophilus showed inhibitor properties against conditional pathogenic bacteria $E$. coli and $S$. aureus. Sterile area varies between $16-18 \mathrm{~mm}$ against $E$. coli and $19-21 \mathrm{~mm}$ against the $S$. aureus. This indicate the functionally properties of selected strains.

Many thermophilic LAB are capable to produce exopolysaccharide (EPS) that play an essential role in texture forming of fermented products [15]. Therefore EPS producing capacity of selected $S$. thermophilus strains are important technological property. In this study were investigated all five selected strains on ability to EPS production.

As a result of the researches, two strains producing EPS were shown: $S$. thermophilus CNMN-LB-50 520 $\pm 10 \mathrm{mg} \cdot \mathrm{l}^{-1}$ and $S$. thermophilus CNMN-LB-51 $436 \pm 10 \mathrm{mg} \cdot \mathrm{l}^{-1}$. In the case of strain S. thermophilus CNMN-LB-52, the amount of EPS was low $-24 \pm 5 \mathrm{mg} \cdot \mathrm{l}^{-1}$. The other 2 strains produce EPS or their amount are very small, and probably co-precipitate with the proteins upon of trichloroacetic acid addition and can no longer be detected after precipitating with ethanol. In general, the EPS yield of strains ranges from $2 \mathrm{mg} \cdot \mathrm{l}^{-1}$ to 600 $\mathrm{mg} \cdot \mathrm{l}^{-1}$ in milk environment [16-18] and the EPS synthesis capacity is individual for each strain of the same taxonomic group.

On the basis of the obtained results were developed 2 starter cultures for yoghurt production: EPS-producing, non-EPS-producing starter culture, as a control sample served the yoghurt fermented by industrial starter culture (S. thermophilus and L. bulgaricus). 3 sets of yoghurt were manufactured in the industrial conditions. The results obtained for the yoghurt samples produced using starter cultures with selected $S$. thermophilus strains and industrial curter culture (table 3) showed that the developed starter culture are suitable to be used in yogurt production.

Table 3

Characteristics of yogurt samples

\begin{tabular}{|l|l|l|l|}
\hline Parameters & Yoghurt EPS & $\begin{array}{l}\text { Yoghurt non- } \\
\text { EPS }\end{array}$ & $\begin{array}{l}\text { Yoghurt industrial } \\
\text { starter }\end{array}$ \\
\hline Fermentation time $[\mathrm{h}]$ & $4.0 \pm 0.1$ & $4.2 \pm 0.1$ & $5.0 \pm 0.1$ \\
\hline $\begin{array}{l}\text { LAB cout }[\log 10 \\
\left.\mathrm{CFU} \cdot \mathrm{g}^{-1}\right]\end{array}$ & $8.8 \pm 0.2$ & $8.4 \pm 0.3$ & $8.3 \pm 0.2$ \\
\hline $\begin{array}{l}\text { Titratable acidity }[\mathrm{g} \\
\text { lactic acid] }\end{array}$ & $0.645 \pm 0.01$ & $0.633 \pm 0.01$ & $0.626 \pm 0.01$ \\
\hline EPS $\left[\mathrm{mg} \cdot \mathrm{l}^{-1}\right]$ & $651 \pm 10$ & - & - \\
\hline
\end{tabular}

Furthermore, developed starter culture possessed the highest fermentation activity comparative with the control sample. The viable count of LAB was at the same level for all samples. No difference was observed between titratable acidity between samples. In additional, the use of EPS starter culture increase the apparent viscosity that improve the consistency of yoghurt due to microstructure formation where EPS binds free water with the lipid and protein complexes of the product $[19,20]$. 


\section{Conclusion}

As a result of the presented research was demonstrated the possibility of isolation from Moldavian raw milk and dairy products of spontaneous fermentation of autochthonous S. thermophilus strains with valuable biotechnological properties for industrial application, such as high antibacterial activity and EPS-producing capacity. The five selected strains of $S$. thermophilus showed characteristics adequate for their use as starter culture for yoghurt production. Developed starter cultures characterized by intense acidification of milk $4.0 \pm 0.2 \mathrm{~h}$ comparative with the industrial starter. The inclusion of EPS S. thermophilus strain clearly improved the apparent viscosity of yoghurt.

Acknowledgements

Author is thankful to Slovak Academic Information Agency (Bratislava, Slovakia) for providing fellowship

\section{References}

1. De Vuyst L., Tsakalidou E. (2008), Streptococcus macedonicus, a multi-functional and promising species for dairy fermentations, International Dairy Journal, 18, pp. 476485. DOI: 10.1016/j.idairyj.2007.10.006.

2. Floch M., Ringel Y., Walker W.A. (2017), The microbiota in gastrointestinal pathophysiology, Academic Press.

3. Fertally S.S., Facklam R.R. (1987), Comparison of physiologic tests used to identify non-beta-hemolytic aerococci, enterococci, and streptococci, Journal of Clinical Microbiology, 25, pp. 1845-1850.

4. Teixeira L.M., FacklamR.R., Steigerwalt A.G., Pgott N.E., Merquior V.L.C., Brenner D.J. (1995), Correlation between phenotypic characteristics and DNA relatedness within Enterococcus faecium strains, Journal of Clinical Microbiology, 33, pp. 15201523.

5. Vancanneyt M., Snauwaert C., Cleenwerck I., Baele M., Descheemaeker P., Goossens H., Pot B., Vandamme P., Swings J., Haesebrouck F., Devriese L.A. (2001), Enterococcus villorum sp. nov., an enteroadherent bacterium associated with diarrhea in piglets, International Journal of Systematic and Evolutionary Microbiology, 51, pp. 393-400. DOI: 10.1099/00207713-51-2-393.

6. Wu K.S., Jones R., Danneberger L., Scolnik P.A. (1994) Detection of microsatellite polymorphisms without cloning, Nucleic Acids Research, 22, pp. 3257-3258. DOI: 10.1093/nar/22.15.3257.

7. Whitman W. B. (Ed.). (2015), Bergey's Manual of Systematics of Archaea and Bacteria, Wiley, New Jersey.

8. Van Den Bogaard P.T.C., Hols P., Kuipers O.P., Kleerebezem M., De Vos M.W. (2002), Sugar utilization and conservation of gal-lac gene cluster in Streptococcus thermophilus, Systematic and Applied Microbiology, 27, pp. 10-17. DOI: 10.1078/0723-2020-00258.

9. Hols P., Hancy F., Fontaine L., Grossiord B., Prozzi D., Leblond-Bourget N., Decaris B., Bolotin A., Delorme C., Ehrlich S.D., Guédon E., Monnet V., Renault P., Kleerebezem M. (2005), New insights in the molecular biology and physiology of 
Streptococcus thermophilus revealed bycomparative genomics, FEMS Microbiology Reviews, 29, pp. 435-463. DOI: 10.1016/j.femsre.2005.04.008.

10. Gilmore M.S., Clewell D.B., Ike Y., Shankar N. (2014), Enterococci: From Commensals to Leading Causes of Drug Resistant Infection, Massachusetts Eye and Ear Infirmary, Boston

11. Dziuba B., Babuchowski A., Nalecz D., Niklewicz M. (2007), Identification of lactic acid bacteria using FTIR spectroscopy and cluster analysis, International Dairy Journal, 17, pp. 183-189. DOI:10.1016/j.idairyj.2006.02.013.

12. Naumann D., Helm D., Labischinski H,. Giesbrecht P. (1991), The Characterization of microorganisms by Fourier-transform infrared spectroscopy (FT-IR), Modern Techniques for Rapid Microbiological Analysis, pp. 43-96.

13. Hickey C.D., Sheehan J.J., Wilkinson M.G., Auty M.A.E. (2015), Growth and location of bacterial colonies within dairy foods using microscopy techniques: a review, Frontiers in Microbiology, 6(99), pp. 1-9. DOI:10.3389/fmicb.2015.00099.

14. Balouirin M., Sadiki M., Koraichilbnsouda S. (2016), Methods for in vitro evaluating antimicrobial activity: A review, Journal of Pharmaceutical Analysis, 6, pp. 71-79. DOI:10.1016/j.jpha.2015.11.005.

15. Feldmane J., Pavels S., Ciprovica I. (2013), Potential of exopolysaccharides in yoghurt production, International Journal of Agricultural, Biosystems Science and Engeneering, 7, pp. 1-4. DOI: 10.1007/s12088-011-0148-8.

16. Vaningelgem F., Zamfir M., Mozzi F., Adriany T., Vancanneyt M., Swings J., De Vuyst L. (2004), Biodiversity of exopolysaccharides produced by Streptococcus thermophilus strains is reflected in their production and their molecular and functional characteristics, Applied Environmental Microbiology, 70, pp. 900-912.

17. De Vuyst L., Zamfir M., Mozzi F., Adriany T., Adriany T., Marshall V., Degeest B., Vaningelgem F. (2003), Exopolysaccharide-producing Streptococcus thermophilus strains as functional starter cultures in the production of fermented milks, International Dairy Journal, 13, pp. 707-717. DOI: 10.1016/S0958-6946(03)00105-5.

18. Wu Q., Tun H.M., Leung F.C., Shah N.P. (2014), Genomic insights into high exopolysaccharide-producing dairy starter bacterium Streptococcus thermophilus ASCC 1275, Scientific Reports, 4, pp. 1-8. DOI: 10.1038/srep04974.

19. Han X., Yang Z., Jing X., Yu P., Zhang Y., Yi H., Zhang L. (2016), Improvement of the Texture of Yogurt by Use of Exopolysaccharide Producing Lactic Acid Bacteria, BioMed Research International, 2016, pp. 1-6. DOI:10.1155/2016/7945675.

20. Cartasev A., Rudic V. (2017), Effect of starter culture producing exopolysaccharide on yoghurt, Chemistry Journal of Moldova, 12(2), pp. 7-12. DOI: 10.19261/cjm.2017.440 


\title{
Assessment of heavy metal concentration in edible fish muscle and water sample collected from different location in Chittagong: a public health concern
}

\author{
Jakia Sultana Jothi ${ }^{1,3}$, Ishrat Zahan Anka ${ }^{1}$, \\ Shaharior Hashem ${ }^{2,3}$, Shamsul Morshed ${ }^{1}$ \\ 1 - Chittagong Veterinary and Animal Sciences University, Bangladesh \\ 2 - Bangladesh Agricultural University, Bangladesh \\ 3 - Hiroshima University, Japan
}

Keywords:

Heavy metal

Water

Sea

Marine fish

Chittagong

Article history:

Received

19.07.2018

Received in

revised form

21.09.2018

Accepted

28.09.2018

Corresponding

author:

Jakia Sultana Jothi

E-mail:

juthi.engg.bau@

gmail.com

DOI:

10.24263/2304-

974X-2018-7-3-11

\section{Abstract}

Introduction. The research was carried out to investigate the concentration of heavy metals in fish and water samples collected from different locations of Chittagong District, Bangladesh.

Materials and methods. The concentrations of heavy metals including $\mathrm{Cr}, \mathrm{Cu}, \mathrm{Ni}, \mathrm{Pb}$ and $\mathrm{Fe}$ in sea water and marine fishes (pama croaker, bombay duck and rat-tail anchovy) were detected by using Air / Acetylene Flame Atomic Absorption Spectrophotometer along Chittagong City areas, Bangladesh.

Results and discussion. The mean concentration of heavy metals were found in water in the range as $\mathrm{Cr} 0.0138-0.0789$ $\mathrm{mg} / \mathrm{L}, \mathrm{Cu} 0.0014-0.0284 \mathrm{mg} / \mathrm{L}$, Ni 0.0259-0.2519 mg/L, Pb $0.0109-0.1596 \mathrm{mg} / \mathrm{L}$ and $\mathrm{Fe} 0.2176-1.787 \mathrm{mg} / \mathrm{L}$. The analysis of water samples showed that the distribution of heavy metals in the order of magnitude as $\mathrm{Fe}>\mathrm{Ni}>\mathrm{Pb}>\mathrm{Cr}>\mathrm{Cu}$. The variation might be due to location, level of contamination in water through industrial effluents and anthropogenic activities. While the mean concentration of heavy metals were found in all fish samples in the range as $\mathrm{Cr} 3.2039-16.3495 \mathrm{mg} / \mathrm{Kg}$ dry wt., $\mathrm{Cu} 1.5589-4.5848 \mathrm{mg} / \mathrm{Kg}$ dry wt., Ni $0.1101-1.9029 \mathrm{mg} / \mathrm{Kg}$ dry wt., $\mathrm{Pb} 0.4373-2.7638 \mathrm{mg} / \mathrm{Kg}$ dry wt. and $\mathrm{Fe} 30.9599-$ $108.780 \mathrm{mg} / \mathrm{Kg}$ dry wt. The distribution of heavy metals in fish samples analyzed were in the order of magnitude as $\mathrm{Fe}>\mathrm{Cr}>$ $\mathrm{Cu}>\mathrm{Pb}>\mathrm{Ni}$. The analysis showed that magnitudes of heavy metal were more or less similar with other researchers. The variation might be due to metal accumulation in fish and various fish species living in the same water body but different level of contamination in water. Among all samples, $17 \%$ fish samples had excess amount of $\mathrm{Cr}$ whereas acceptable limit is $15.0 \mathrm{mg} / \mathrm{kg}$ for fish. Mean concentrations of $\mathrm{Pb}$ in all fish samples were $17 \%$ below detection level, $33 \%$ optimum and $33 \%$ higher than the maximum permitted concentrations $(1.5$ $\mathrm{mg} / \mathrm{Kg}$ ). Fe in all fish samples were 33\% below, 17\% optimum and $50 \%$ higher than the maximum permitted concentrations (43 $\mathrm{mg} / \mathrm{Kg}$ ) recommended by $\mathrm{FAO} / \mathrm{WHO}$.

Conclusions. Most of the fish species studied are safe to be consumed. Therefore, this study is proposed to draw the attention of health and environmental authorities in need for appropriate regulatory framework. 


\section{Introduction}

Fish, as human food, are considered as a good source of protein, polyunsaturated fatty acids (particularly omega-3 fatty acids), calcium, zinc (Zn), and iron [1]. Due to the lower cost and higher nutritive value, it is one of the most important sources among the food products of animal origin [2,3]. In future, seafood will be an vital source of food protein and the safety for human consumption of products from aquaculture is of public health interest [4].

Heavy metals are an important source of food contamination and health hazard. The main threats to human health are associated with exposure to arsenic, cadmium, lead and mercury and copper. Absorption of heavy metals through food has been shown to have serious consequences on health- such as kidney disease, damage to the nervous system, diminished intellectual capacity, heart disease, gastrointestinal diseases, bone fracture, cancer and death [5].

Heavy metals are contaminants in the aquatic environment as well as became toxic health threat for human. Fish play important role in condensing the toxicity of heavy metals which have a great ecological significance due to their cumulative behavior and toxicity [3].

The most anthropogenic sources of metals are industrial, petroleum contamination and sewage disposal $[6,7]$. The aim of this study was to assess the levels of some heavy metals in water and fish specimens caught from different localities in Chittagong coastal area, Bangladesh. Public health importance and the hazardous toxic effects of these heavy metals and fish contamination with these were discussed.

\section{Materials and methods}

\section{Collection of water samples}

The water samples were obtained from 12 sampling stations established along 5 regions (Figure 1). The sampling stations were chosen based on an experimental scheme design following human activities in the area. These regions are main fishing centers of Chittagong, Bangladesh and also, a variety of industries and touristic centers are concentrated in these regions. Following the large volume of population and industries located there, the five regions were selected to measure the heavy metals concentrations in water samples during summer season (Table 1).

Table 1

List of sampling stations for water collection from Chittagong, Bangladesh

\begin{tabular}{|c|c|}
\hline Sampling station Code & Regions \\
\hline $\mathrm{W}_{1}$ & \multirow{2}{*}{ Majhir Ghat } \\
\hline $\mathrm{W}_{2}$ & \\
\hline $\mathrm{W}_{3}$ & \multirow{2}{*}{ Firingi Bazar } \\
\hline $\mathrm{W}_{4}$ & \\
\hline $\mathrm{W}_{5}$ & \multirow{2}{*}{ Sea-resource Ghat } \\
\hline $\mathrm{W}_{6}$ & \\
\hline $\mathrm{W}_{7}$ & \multirow{2}{*}{ Chaktai Khal } \\
\hline $\mathrm{W}_{8}$ & \\
\hline $\mathrm{W}_{9}$ & \multirow{2}{*}{ Uttar Kattoli } \\
\hline $\mathrm{W}_{10}$ & \\
\hline $\mathrm{W}_{11}$ & \multirow{2}{*}{ Uttar Kattoli Pond } \\
\hline $\mathrm{W}_{12}$ & \\
\hline
\end{tabular}




\section{Collection of fish specimens}

Pama croaker (Otolithoides pama), bombay duck (Harpadon nehereus) and rat-tail anchovy (Coilia ramcarati) were collected from four different market in Chittagong Metropolitan area, Bangladesh (Table 2). Twenty fish of each species were collected from each market. The fish were washed with deionized water and wrapped separately in acid washed polyethylene bags and were stored frozen at $-20^{\circ} \mathrm{C}$ until analysis.

\section{Materials}

All reagents used in this work $\left(\mathrm{HNO}_{3}, \mathrm{NaOH}, \mathrm{HCl}, \mathrm{KI}, \mathrm{HClO}_{4}, \mathrm{~K}_{2} \mathrm{CrO}_{4}, \mathrm{NaBH}_{4}\right.$, acetylene and argon gas) were of analytical grade and purchased from Merck (Germany).

List of market for fish collection in Chittagong, Bangladesh

Table 2

\begin{tabular}{|c|c|c|c|}
\hline \multirow{2}{*}{ Location } & \multicolumn{3}{|c|}{ Fish Samples code } \\
\cline { 2 - 4 } & Pama croaker & Bombay duck & Rat-tail anchovy \\
\hline Market 1 & $\mathrm{P}_{1}$ & $\mathrm{~B}_{1}$ & $\mathrm{R}_{1}$ \\
\hline Market 2 & $\mathrm{P}_{2}$ & $\mathrm{~B}_{2}$ & $\mathrm{R}_{2}$ \\
\hline Market 3 & $\mathrm{P}_{3}$ & $\mathrm{~B}_{3}$ & $\mathrm{R}_{3}$ \\
\hline Market 4 & $\mathrm{P}_{4}$ & $\mathrm{~B}_{4}$ & $\mathrm{R}_{4}$ \\
\hline
\end{tabular}

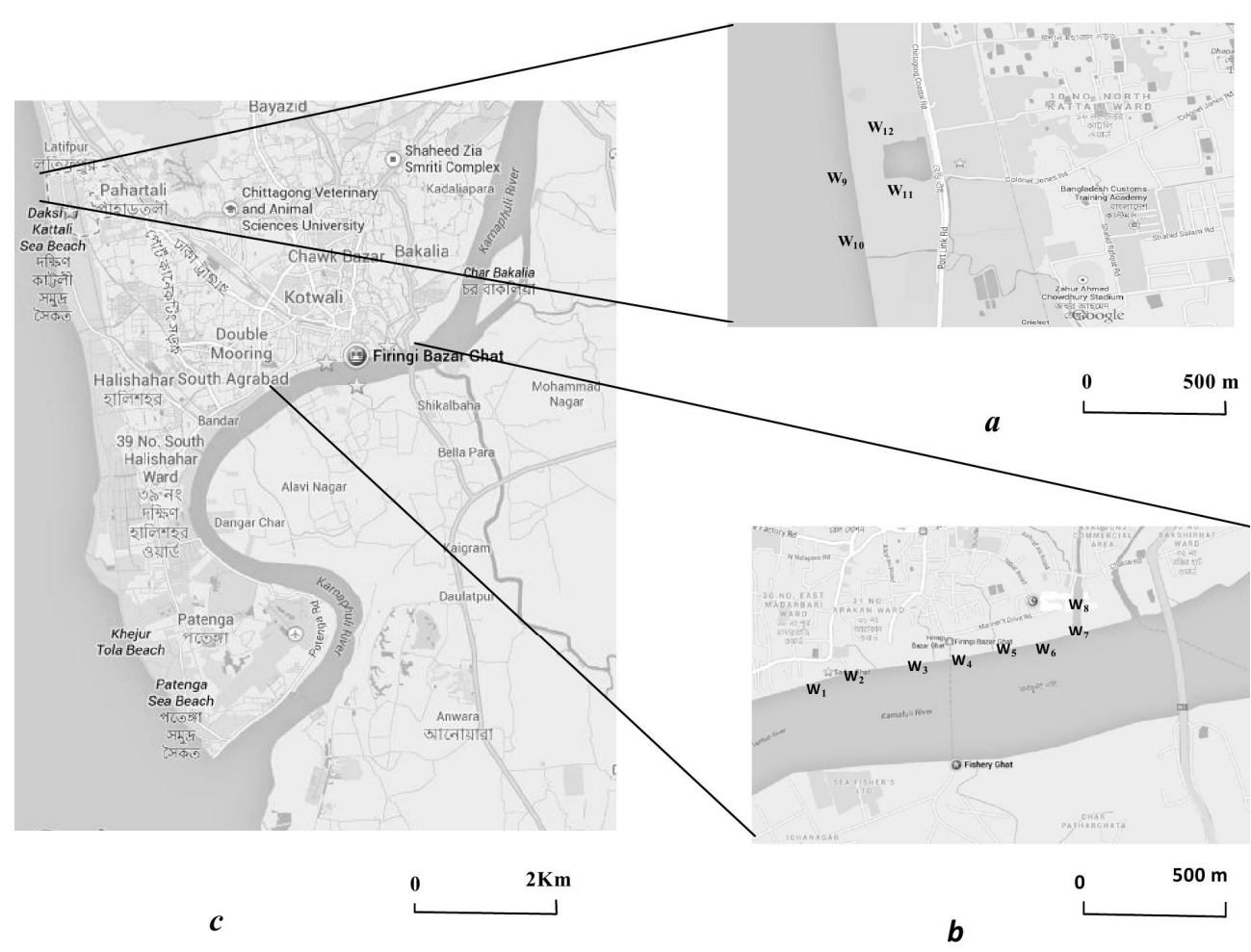

Figure 1. Location map of the study areas (Source: Google map, 2018) 


\section{Preparation and analysis of water samples}

The water samples were preserved by the addition of $1 \mathrm{ml}$ of concentrated nitric acid per liter until the time of analysis. The analysis of water samples was carried out according to American Public Health Association [8]. They were filtered through $0.45 \mu$ membrane filter. The required volume $(100 \mathrm{ml})$ of the filtrate was used to measure heavy metal levels in water samples by using Air/ Acetylene Flame Atomic Absorption Spectrophotometer.

\section{Preparation and analysis of fish specimens}

Fish samples were allowed for thawing and the skin of the fish was removed using a plastic knife to avoid metal contamination. The muscles of fish were taken into pre-acid washed crucibles and they were homogenized separately. The weight of each homogenized sample was recorded. Then the samples were kept in a drying oven at $100^{\circ} \mathrm{C}$ for more than $24 \mathrm{hrs}$ until a constant weight was observed. The dried samples were then ground into a fine powder using a porcelain motor and a pestle. Powdered fish tissues were digested using a dry ashing procedure [9]. They were filtered through $0.45 \mu$ membrane filter. The required volume $(100 \mathrm{ml})$ of the filtrate was used to measure heavy metal levels in water samples by using Air/ Acetylene Flame Atomic Absorption Spectrophotometer.

At each step of digestion processes, acid blanks were prepared in order to ensure that the samples and chemicals used were not contaminated. They were analyzed by atomic absorption spectrophotometer. Each set of digestion has its own acid blank and was corrected by using its blank.

Each standard solution was measured 3 times and the mean were plotted. A blank solution of distilled water was used to check accuracy of the standard solutions and it was run after every 10 samples.

The metal content will be calculated using the formula:

$$
C=\frac{C_{A A S} \cdot V}{W}
$$

where $\mathrm{C}$ - concentration (mg Kg ${ }^{-1}$ or ppm dry wt.)

$\mathrm{C}_{\mathrm{AAS}}-$ concentration of the element through AAS (ppm)

$\mathrm{V}$ - volume made up

\section{Data Analysis}

The data obtained from the experiments were statistically analyzed for find out mean and standard deviation among the various samples in triplicate. Data were analyzed using the software, IBM SPSS Statistics, version 20 at the 0.05 level.

\section{Results and dscussion}

\section{Heavy metal in sea water}

The Mean concentrations and associated standard deviations of $\mathrm{Cr}, \mathrm{Cu}, \mathrm{Ni}, \mathrm{Pb}$ and $\mathrm{Fe}$ in sea water are presented in Table 3. The mean concentration of heavy metals were found in water in the range as $\mathrm{Cr} 0.0138-0.0789 \mathrm{mg} / \mathrm{L}, \mathrm{Cu} 0.0014-0.0284 \mathrm{mg} / \mathrm{L}, \mathrm{Ni} 0.0259$ $0.2519 \mathrm{mg} / \mathrm{L}, \mathrm{Pb} 0.0109-0.1596 \mathrm{mg} / \mathrm{L}$ and $\mathrm{Fe} 0.2176-1.787 \mathrm{mg} / \mathrm{L}$. The distribution of heavy metals in water samples analyzed were in the order of magnitude as $\mathrm{Fe}>\mathrm{Ni}>\mathrm{Pb}>$ 
$\mathrm{Cr}>\mathrm{Cu}$. Ismail and Saleh (2012) [10] detected heavy metals of water in the order of Fe > $\mathrm{Cu}$, whereas concentrations $\mathrm{Pb}$ was below the detection limit. According to El-Kattan (2018) [3], the contents of heavy metals in water were in the order of degree as $\mathrm{Cr}>\mathrm{Cu}>$ $\mathrm{Pb}>$ Fe. Kumar et al. (2013) [12] also found heavy metal concentrations in Ennore creek sea water decreased in the order of $\mathrm{Cu}>\mathrm{Cr}>\mathrm{Ni}>\mathrm{Pb}$. The analysis showed that magnitudes of heavy metal were more or less similar with Ismail and Saleh (2012) [10] reported but differ from Ambedkar and Muniyan (2012) [11] and Kumar et al. (2013) [12]. The variation might be due to location, level of contamination in water through industrial effluents and anthropogenic activities.

Table 3

Concentration of heavy metal in sea water*

\begin{tabular}{|c|c|c|c|c|c|}
\hline $\begin{array}{c}\text { Sampling } \\
\text { station } \\
\text { Code }\end{array}$ & $\mathbf{C r}(\mathbf{m g} / \mathbf{l})$ & $\mathbf{C u}(\mathbf{m g} / \mathbf{l})$ & $\mathbf{N i}(\mathbf{m g} / \mathbf{l})$ & $\mathbf{P b}(\mathbf{m g} / \mathbf{l})$ & $\mathbf{F e}(\mathbf{m g} / \mathbf{l})$ \\
\hline $\mathrm{W}_{1}$ & $0.0530 \pm 0.0034$ & $0.0251 \pm 0.0038$ & $0.0259 \pm 0.0091$ & $0.1555 \pm 0.0130$ & $1.140 \pm 0.0340$ \\
\hline $\mathrm{W}_{2}$ & $0.0252 \pm 0.0234$ & $0.0188 \pm 0.0053$ & $0.0384 \pm 0.0017$ & $0.1596 \pm 0.0204$ & $1.270 \pm 0.0586$ \\
\hline $\mathrm{W}_{3}$ & $0.0303 \pm 0.0244$ & $0.0163 \pm 0.0039$ & $0.2350 \pm 0.0064$ & $0.0118 \pm 0.0013$ & $1.196 \pm 0.0387$ \\
\hline $\mathrm{W}_{4}$ & $0.0138 \pm 0.0123$ & $0.0284 \pm 0.0060$ & $0.2519 \pm 0.0035$ & $0.0109 \pm 0.0054$ & $1.280 \pm 0.0206$ \\
\hline $\mathrm{W}_{5}$ & $0.0518 \pm 0.0173$ & $0.0119 \pm 0.0070$ & $0.0568 \pm 0.0039$ & $0.1379 \pm 0.0141$ & $1.252 \pm 0.0179$ \\
\hline $\mathrm{W}_{6}$ & $0.0789 \pm 0.0197$ & $0.0081 \pm 0.0057$ & $0.0815 \pm 0.0026$ & $0.1313 \pm 0.0241$ & $1.342 \pm 0.0431$ \\
\hline $\mathrm{W}_{7}$ & $0.0310 \pm 0.0060$ & $0.0183 \pm 0.0034$ & $0.2007 \pm 0.0007$ & $0.0265 \pm 0.0039$ & $1.787 \pm 0.0088$ \\
\hline $\mathrm{W}_{8}$ & $0.0168 \pm 0.0058$ & $0.0259 \pm 0.0021$ & $0.2024 \pm 0.0026$ & $0.0129 \pm 0.0060$ & $1.325 \pm 0.0063$ \\
\hline $\mathrm{W}_{9}$ & $0.0237 \pm 0.0096$ & $0.0035 \pm 0.0019$ & $0.1179 \pm 0.0049$ & $0.1196 \pm 0.0117$ & $0.3382 \pm 0.0150$ \\
\hline $\mathrm{W}_{10}$ & $0.0304 \pm 0.0230$ & $0.0036 \pm 0.0013$ & $0.1348 \pm 0.0044$ & $0.1033 \pm 0.0190$ & $0.2848 \pm 0.0084$ \\
\hline $\mathrm{W}_{11}$ & $\mathrm{BDL}$ & $0.0014 \pm 0.0001$ & $0.1770 \pm 0.0037$ & $0.0976 \pm 0.0049$ & $0.3475 \pm 0.0303$ \\
\hline $\mathrm{W}_{12}$ & $\mathrm{BDL}$ & BDL & $0.1998 \pm 0.0024$ & $0.0662 \pm 0.0336$ & $0.2176 \pm 0.0106$ \\
\hline
\end{tabular}

* Values are mean \pm standard deviation of triplet determinations; BDL=Below Detection Level

The highest concentration level of $\mathrm{Cr}$ was found in $\mathrm{W}_{6}(0.0789 \mathrm{mg} / \mathrm{L})$, while the least concentration was detected in $\mathrm{W}_{4}(0.0138 \mathrm{mg} / \mathrm{L})$. But $\mathrm{Cr}$ was found below the detection level in pond water. $\mathrm{Cu}$ content in $\mathrm{W}_{4}(0.0284 \mathrm{mg} / \mathrm{L})$ was higher followed by lowest in $\mathrm{W}_{11}$ $(0.0014 \mathrm{mg} / \mathrm{L})$. In pond water sample $\left(\mathrm{W}_{12}\right) \mathrm{Cu}$ was analyzed below the detection limit. The highest Ni content was found $0.2519 \mathrm{mg} / \mathrm{L}$ in sample $\mathrm{W}_{4}$ and lowest value $0.0259 \mathrm{mg} / \mathrm{L}$ for sample $\mathrm{W}_{1}$. The maximum concentration of $\mathrm{Pd}$ was observed in $\mathrm{W}_{2}(0.1596 \mathrm{mg} / \mathrm{L})$ whereas minimum concentration was observed in $\mathrm{W}_{4}(0.0109 \mathrm{mg} / \mathrm{L})$. The level of Fe was detected highest in sample $W_{7}(1.787 \mathrm{mg} / \mathrm{L})$ and lowest in $\mathrm{W}_{12}(0.2176 \mathrm{mg} / \mathrm{L})$.

Kumar et al. (2013) [12] studied on the heavy metal content in sea water and showed that the $\mathrm{Cu}$ ranged from 45.29 to $51.02 \mathrm{mg} / \mathrm{L}, \mathrm{Cr} 11.60$ to $15.75 \mathrm{mg} / \mathrm{L}, \mathrm{Ni} 12.01$ to 15.69 $\mathrm{mg} / \mathrm{L}$ and $\mathrm{Pb} 4.10$ to $6.20 \mathrm{mg} / \mathrm{L}$. Ambedkar and Muniyan (2012) [11] analyzed $\mathrm{Cr}, \mathrm{Cu}, \mathrm{Pb}$ and Fe content in water. They found $0.70 \pm 0.026 \mathrm{mg} / \mathrm{L} \mathrm{Cr}, 0.50 \pm 0.025 \mathrm{mg} / \mathrm{L} \mathrm{Cu}, 0.46 \pm$ $0.018 \mathrm{mg} / \mathrm{L} \mathrm{Pb}$ and $0.32 \pm 0.015 \mathrm{mg} / \mathrm{L} \mathrm{Fe}$ in water. The analysis detected that all water samples were lower $\mathrm{Cu}, \mathrm{Cr}, \mathrm{Ni}$ and $\mathrm{Pb}$ content than the range reported by Kumar et al. (2013) [12] and Ambedkar and Muniyan (2012) [11] but higher Fe content was found than Ambedkar and Muniyan (2012) [11]. Accumulation of heavy metals in the aquatic environments have been associated with urban runoff, sewage treatment plants, industrial effluents and wastes, mining operations, boating activities, domestic garbage dumps and agricultural fungicide runoff [13]. 


\section{Heavy metal in sea fish}

The Mean concentrations and associated standard deviations of $\mathrm{Cr}, \mathrm{Cu}, \mathrm{Ni}, \mathrm{Pb}$ and $\mathrm{Fe}$ in sea fish (pama croaker, bombay duck and rat-tail anchovy) are presented in Table 4. The mean concentration of heavy metals were found in all fish samples in the range as $\mathrm{Cr}$ $3.2039-16.3495 \mathrm{mg} / \mathrm{Kg}$ dry wt., $\mathrm{Cu} 1.5589-4.5848 \mathrm{mg} / \mathrm{Kg}$ dry wt., Ni $0.1101-1.9029$ $\mathrm{mg} / \mathrm{Kg}$ dry wt., $\mathrm{Pb} 0.4373-2.7638 \mathrm{mg} / \mathrm{Kg}$ dry wt. and Fe $30.9599-108.780 \mathrm{mg} / \mathrm{Kg}$ dry wt. The distribution of heavy metals in fish samples analyzed were in the order of magnitude as $\mathrm{Fe}>\mathrm{Cr}>\mathrm{Cu}>\mathrm{Pb}>\mathrm{Ni}$. Jezierska and Witeska (2006) [14] detected heavy metals in live fish usually follow the ranking: $\mathrm{Fe}>\mathrm{Pb}>\mathrm{Cu}>\mathrm{Cd}>\mathrm{Hg}$. According to Ambedkar and Muniyan (2012) [11], the contents of heavy metals in the all fish organs analyzed were in the order of $\mathrm{Cr}>\mathrm{Cu}>\mathrm{Pb}>\mathrm{Fe}$. The analysis showed that magnitudes of heavy metal were more or less similar with Jezierska and Witeska (2006) [14] reported but differ from Ambedkar and Muniyan (2012) [11]. The variation might be due to metal accumulation in fish and various fish species living in the same water body with different level of contamination in water.

\section{Concentration of heavy metal in sea water fish*}

Table 4

\begin{tabular}{|c|c|c|c|c|c|}
\hline $\begin{array}{c}\text { Fish } \\
\begin{array}{c}\text { Sample } \\
\text { Code }\end{array}\end{array}$ & $\begin{array}{c}\text { Cr (mg/Kg } \\
\text { dry wt.) }\end{array}$ & $\begin{array}{c}\text { Cu (mg/Kg } \\
\text { dry wt.) }\end{array}$ & $\begin{array}{c}\text { Ni (mg/Kg } \\
\text { dry wt.) }\end{array}$ & $\begin{array}{c}\text { Pb (mg/Kg } \\
\text { dry wt.) }\end{array}$ & $\begin{array}{c}\text { Fe (mg/Kg } \\
\text { dry wt.) }\end{array}$ \\
\hline $\mathrm{P}_{1}$ & $5.8931 \pm 0.4799$ & $2.9826 \pm 0.0519$ & $1.2259 \pm 0.0201$ & $1.5247 \pm 0.1430$ & $34.3399 \pm 0.7788$ \\
\hline $\mathrm{P}_{2}$ & $3.6049 \pm 0.0702$ & $4.0512 \pm 0.0246$ & $1.1303 \pm 0.0509$ & $1.7494 \pm 0.1561$ & $78.4812 \pm 0.6901$ \\
\hline $\mathrm{P}_{3}$ & $5.7798 \pm 0.6082$ & $2.8343 \pm 0.0615$ & $1.0733 \pm 0.0423$ & $1.5914 \pm 0.2352$ & $30.9599 \pm 0.6071$ \\
\hline $\mathrm{P}_{4}$ & $3.5654 \pm 0.4884$ & $4.0548 \pm 0.0246$ & $1.1680 \pm 0.0588$ & $1.6669 \pm 0.1727$ & $79.2792 \pm 0.1692$ \\
\hline $\mathrm{B}_{1}$ & $3.2039 \pm 0.2504$ & $2.8581 \pm 0.0246$ & $1.9029 \pm 0.0217$ & $1.9964 \pm 0.0859$ & $39.0306 \pm 0.7464$ \\
\hline $\mathrm{B}_{2}$ & $4.1452 \pm 0.4207$ & $2.1553 \pm 0.0292$ & $0.8601 \pm 0.0469$ & $0.5675 \pm 0.0489$ & $34.9958 \pm 0.2801$ \\
\hline $\mathrm{B}_{3}$ & $3.2842 \pm 0.3392$ & $2.6436 \pm 0.0292$ & $1.7545 \pm 0.0491$ & $1.5193 \pm 0.2173$ & $37.5378 \pm 0.2475$ \\
\hline $\mathrm{B}_{4}$ & $4.3846 \pm 0.4186$ & $2.1408 \pm 0.0604$ & $0.7716 \pm 0.0073$ & $0.4373 \pm 0.1759$ & $35.079 \pm 0.2426$ \\
\hline $\mathrm{R}_{1}$ & $16.3495 \pm 0.480$ & $4.5848 \pm 0.3676$ & $0.9126 \pm 0.1773$ & $2.7638 \pm 0.3460$ & $108.780 \pm 1.778$ \\
\hline $\mathrm{R}_{2}$ & $9.7973 \pm 0.3718$ & $1.6085 \pm 0.1129$ & $0.1101 \pm 0.0915$ & $\mathrm{BDL}$ & $91.913 \pm 4.043$ \\
\hline $\mathrm{R}_{3}$ & $16.1246 \pm 0.584$ & $4.1436 \pm 0.1514$ & $0.5969 \pm 0.1071$ & $2.5346 \pm 0.8953$ & $106.618 \pm 1.289$ \\
\hline $\mathrm{R}_{4}$ & $8.1584 \pm 0.3056$ & $1.5589 \pm 0.3856$ & $0.1459 \pm 0.1077$ & $\mathrm{BDL}$ & $92.822 \pm 0.914$ \\
\hline
\end{tabular}

* Values are mean \pm standard deviation of triplet determinations; BDL=Below Detection Level

The highest concentration level of $\mathrm{Cr}$ was found in $\mathrm{P}_{1}\left(5.8931 \mathrm{mg} / \mathrm{Kg}\right.$ dry wt.), $\mathrm{B}_{4}$ (4.3846 mg/Kg dry wt.) and $\mathrm{R}_{1}(16.3495 \mathrm{mg} / \mathrm{Kg}$ dry wt.) in pama croaker, bombay duck and rat-tail anchovy respectively. Contamination levels of heavy metal in fish are normally compared to the permissible limits recommended by Food and Agriculture Organization (FAO) and World Health Organization (WHO) [15]. In this research, 17\% fish samples had excess amount of $\mathrm{Cr}$ among all samples whereas acceptable limit is $15.0 \mathrm{mg} / \mathrm{kg}$ for fish according to $[15,16]$. Furthermore, chromium is also more harmful in its lower oxidation state (III). Chromium and chromates are potential carcinogens [17]. 
The maximum concentration of $\mathrm{Cu}$ was observed in $\mathrm{P}_{4}\left(4.0548 \mathrm{mg} / \mathrm{Kg}\right.$ dry wt.), $\mathrm{B}_{1}$ ( $2.8581 \mathrm{mg} / \mathrm{Kg}$ dry wt.) and $\mathrm{R}_{1}(4.5848 \mathrm{mg} / \mathrm{Kg}$ dry wt.) in pama croaker, bombay duck and rat-tail anchovy respectively. Mean concentration of $\mathrm{Cu}$ in fish samples was lower compared with FAO/WHO (1984) [15] permissible level (20 mg/Kg). Though copper is an essential element that serves as a cofactor in a number of enzymes systems and necessary for the synthesis of hemoglobin, very high intake of $\mathrm{Cu}$ can cause adverse health problems for most living organism [18].

The level of Ni was detected highest in sample $\mathrm{P}_{4}\left(1.1680 \mathrm{mg} / \mathrm{Kg}\right.$ dry wt.), $\mathrm{B}_{1}(1.9029$ $\mathrm{mg} / \mathrm{Kg}$ dry wt.) and $\mathrm{R}_{3}\left(0.5969 \mathrm{mg} / \mathrm{Kg}\right.$ dry wt.) and lowest in $\mathrm{P}_{3}\left(1.0733 \mathrm{mg} / \mathrm{Kg}\right.$ dry wt), $\mathrm{B}_{4}$ $\left(0.7716 \mathrm{mg} / \mathrm{Kg}\right.$ dry wt.) and $\mathrm{R}_{2}(0.1101 \mathrm{mg} / \mathrm{Kg}$ dry wt.) in pama croaker, bombay duck and rat-tail anchovy respectively. According to the FAO/WHO (1984) [15] maximum permissible concentration is $80 \mathrm{mg} / \mathrm{Kg}$ for $\mathrm{Ni}$ in fish muscle. In this study, Ni concentration for all studied fish species was lower than $\mathrm{FAO} / \mathrm{WHO}$ standard [15].

$\mathrm{Pb}$ content in $\mathrm{P}_{2}\left(1.7494 \mathrm{mg} / \mathrm{Kg}\right.$ dry wt.), $\mathrm{B}_{1}\left(1.9964 \mathrm{mg} / \mathrm{Kg}\right.$ dry wt.) and $\mathrm{R}_{3}(2.5346$ $\mathrm{mg} / \mathrm{Kg}$ dry wt.) were higher in pama croaker, bombay duck and rat-tail anchovy respectively. It was found that mean concentrations of $\mathrm{Pb}$ in all fish samples were $17 \%$ below detection level (BDL), 17\% below, 33\% optimum and 33\% higher than the maximum permitted concentrations $(1.5 \mathrm{mg} / \mathrm{Kg})$ recommended by FAO/WHO [15]. Lead toxicity is known to cause musculo-skeletal, renal, ocular, neurological, immunological, reproductive and developmental effects [11].

The highest Fe content was found in sample $\mathrm{P}_{4}\left(79.2792 \mathrm{mg} / \mathrm{Kg}\right.$ dry wt.), sample $\mathrm{B}_{1}$ (39.0306 mg/Kg dry wt.) and Sample $R_{1}(108.780 \mathrm{mg} / \mathrm{Kg}$ dry wt.) while the lowest value was found $30.9599 \mathrm{mg} / \mathrm{Kg}$ dry wt. in sample $\mathrm{P}_{3}, 34.9958 \mathrm{mg} / \mathrm{Kg}$ dry wt. in sample $\mathrm{B}_{2}$ and $91.913 \mathrm{mg} / \mathrm{Kg}$ dry wt. in sample $\mathrm{R}_{2}$ for pama croaker, bombay duck and rat-tail anchovy respectively. It was found that mean concentrations of $\mathrm{Fe}$ in all fish samples were $33 \%$ below, $17 \%$ optimum and 50\% higher than the maximum permitted concentrations (43 $\mathrm{mg} / \mathrm{Kg}$ ) recommended by $\mathrm{FAO} / \mathrm{WHO}$ [15]. Excess amount of iron causes rapid increase in pulse rate and coagulation of blood in blood vessels, hypertension and drowsiness [17].

The presence of heavy metal in the fish sample might be due to untreated industrial discharges, sewage effluents, illegal waste dumping activity, nearby chemical fertilizer industries, domestic wastes and some anthropogenic activities.

\section{Conclusion}

Metal has a variety of unpleasant effects, which can impact individual health and produce different harmful changes in human. Knowledge of heavy metal concentrations in sea water and marine fishes are important in order to regulate the consumption of fish. The distribution of heavy metals in water samples analyzed were in the order of magnitude as $\mathrm{Fe}>\mathrm{Ni}>\mathrm{Pb}>\mathrm{Cr}>\mathrm{Cu}$. On the other hand, among the metals analyzed in fish muscle, $\mathrm{Cr}$, $\mathrm{Pb}$ and $\mathrm{Fe}$ were with the highest concentration, while $\mathrm{Cu}$ and $\mathrm{Ni}$ had the lowest level according to FAO/WHO (1984) [15]. Though the results reveal some higher heavy metal content in fish, it is important to examine the metal concentration in fish through constant monitoring. The metal contaminants perhaps pose little hazard to human for fish consumption. Therefore, future studies should focus on health risks posed by metal contamination in the other biological factor along with seasonal variations. 


\section{References}

1. Chan H. M., Trifonopoulos M., Ing A., Receveur O., Johnson E. (1999), Consumption of freshwater fish in Kahnawake: risks and benefits, Environmental Research, 80(2), pp. 213222.

2. Darwish A.M., El- Mossalami M.K., El- Bassiony R.A. (2003), Quality assurance of some fatty fishes, Assuit Veterinary Medical Journal, 49 (98), pp. 79-96.

3. El-Kattan, Y.A., Nahla, A. Abo-El Roos. (2008), Levels of some heavy metals in River Nile water and Oreochromis niloticus fish at Menoufia Governorate, Egyptian Journal of Comparative Pathology \& Clinical Pathology, 21(1), pp. 64-75.

4. WHO, (1999), Food safety issues associated with products from aquaculture, Report of a Joint FAO/NACA/WHO Study Group, World Health Organization Technical Report Series 883 , pp. $1-55$.

5. Jarup L. (2003), Hazards of heavy metal contamination, British Medical Journal, 68, pp. 167-182.

6. Saeed S. M., Shaker I. M., (2008), Assessment of heavy metals pollution in water and sediments and their effect on Oreochromis niloticus in the northern delta lakes, Egypt, 8th International Symposium on Tilapia in Aquaculture, pp. 475.

7. Santos, I. R., Silva-Filho E. V., Schaefer C. E., Albuquerque- Filho M. R., Campos. L. S. (2005), Heavy metals contamination in coastal sediments and soils near the Brazilian Antarctic Station, King George Island, Marine Pollution Bulletin, 50, pp. 85-194.

8. A.P.H.A. (American Public Health Association) (1985), Standard methods for examination of water and waste water, 16th Ed. Washington, D.C.

9. Jorhem, L., (1993), Determination of metals in foodstuffs by atomic absorption spectrometry after dry ashing: NMKL interlaboratory study of $\mathrm{Pb}, \mathrm{Cd}, \mathrm{Zn}, \mathrm{Cu}, \mathrm{Fe}, \mathrm{CR}$ and $\mathrm{Ni}$, Journal of AOAC international, 76, pp. 798-815.

10. Ismail I., Saleh M. I., (2012), Analysis Of Heavy Metals In Water And Fish (Tilapia Sp.) Samples From Tasik Mutiara, Puchong, The Malaysian Journal of Analytical Sciences, 16 (3), pp. 346-352.

11. Ambedkar G., Muniyan M. (2012), Analysis of heavy metals in water, sediments and selected freshwater fish collected from gadilam river, tamilnadu, india, International Journal of Toxicology and Applied Pharmacology, 2(2), pp. 25-30.

12. Kumar C.S., Jaikumar M., Robin R.S., Karthikeyan P., Kumar C.S., (2013), Heavy Metal Concentration of Sea Water and Marine Organisms in Ennore Creek, Southeast Coast of India, The Journal of Toxicology and Health, 103, pp. 192-201.

13. Alemdaroglu T., Onur E., Erkakan F. (2003), Trace metal levels in surface sediments of lake Manyas, Turkey and Tributary River, International Journal of Environmental Studies, 60, pp. 287-298.

14. Jezierska B., Witeska, M. (2006), The metal uptake and accumulation in fish living in polluted waters; Soil and Water Pollution Monitoring, Protection and Remediation Springer, pp. 3-23.

15. FAO/WHO (1984), List of maximum levels recommended for contaminants by the Joint FAO/WHO Codex Alimentarius Commission. Second Series CAC/FAL, Rome, pp. 1-8.

16. FEPA (Federal Environmental Protection Agency) (2003), Guidelines and standards for Environmental Pollution Control in Nigeria, pp. 238.

17. Patil G., Ahmed I., (2011), Heavy metals contamination assesment of kanhargaon dam water near chhindwara city, Acta Chimica and Pharmaceutica Indica, 1(1), pp. 7-9.

18. Sivaperumal P, Sankar T V, Nair Viswanathan P.G. (2007), Heavy metals concentrations in fish, shellfish and fish products from internal markets of India visàvis international standards, Food Chemistry, 102, pp. 612-620. 


\title{
Intensification of cooling of tubular blown polymeric packing films with the flowing-down liquid film
}

\author{
Ihor Mikulionok ${ }^{1}$, Arkadii Petukhov ${ }^{1}$, \\ Viktor Gapon ${ }^{1}$, Oleksandr Gavva ${ }^{2}$ \\ 1 - National Technical University of Ukraine "Igor Sikorsky Kyiv Polytechnic Institute", \\ Kyiv, Ukraine \\ 2 - National University of Food Technologies, Kyiv, Ukraine
}

\section{Keywords: \\ Packing \\ Polymer \\ Extrusion \\ Film \\ Cooling}

\section{Article history:}

Received

03.07.2018

Received in

revised form

18.09.2018

Accepted

28.09.2018

Corresponding author:

Ihor Mikulionok

E-mail:

i.mikulionok@

kpi.ua

DOI:

10.24263/2304-

974X-2018-7-3-12

\section{Abstract}

Introduction. Analytical and natural researches of process of cooling of a packing film of low density polyethylene (LDPE; high pressure polyethylene) are conducted by the flowing-down water film.

Material and methods. Pilot studies of cooling of the film are conducted at the following parameters: film type - flat; speed of the film $-0.03-0.50 \mathrm{~m} / \mathrm{s}$; sizes of the slot-hole distributor of a water film: slot size $-0.4-0.8 \mathrm{~mm}$, slot width $-300 \mathrm{~mm}$; temperature of the cooling water $-15-40{ }^{\circ} \mathrm{C}$. Rational parameters of process of cooling are determined on the basis of mathematical modeling.

Results and discussion. Parameters of a liquid film change only on an entrance zone and depend on liquid concentration, speed of the polymeric tube and initial distribution of speed of the liquid at the exit from a distributive ring. At high values of liquid concentration (Re $>20000)$ only the wall layer of liquid participates in heat exchange.

For the film from LDPE its external surface hardens at distance about $0.01 \mathrm{~m}$ from the beginning of contact with water, and an internal surface - at distance about $0.10-0.15 \mathrm{~m}$. Therefore the ring for distribution of liquid needs to be established after the termination of a blowing zone of the polymeric tubular workpiece. It is also necessary to provide the steady movement of a continuous liquid film on an external surface of a polymeric tube on length to $0.2 \mathrm{~m}$ from the beginning of contact of liquid from the polymeric film.

Temperature of the cooling water in the range of $20-60{ }^{\circ} \mathrm{C}$ significantly does not influence both intensity of cooling process, and physical-mechanical properties of the produced polymeric film.

For thick films from LDPE (thickness more than $200 \mu \mathrm{m}$ ) and over $1 \mathrm{~m}$ wide intensity of cooling is limited to the critical liquid concentration.

For practical application of the received results the nomogram for determination of volume liquid concentration of the cooling water, and also volume productivity of the technological line depending on the sizes of a ready tubular blown polymeric film is offered.

Conclusion. The scientific value of results consists in definition of rational conditions of application of liquid cooling of the tubular blown polymeric films produced by extrusion. 


\section{Introduction}

Process of cooling of an extruded tubular blown polymeric film significantly influences productivity of the film technological line and quality of the produced product. Due to relative simplicity of constructive and technological realization of process of cooling the air method is the most widespread. However the air method of cooling can not always correspond to high productivity of the basic machine of the film line, namely a screw extruder, especially at production of thick polymeric films [1-4].

It is essential to increase efficiency and intensity of cooling of a polymeric tubular blown polymeric film by means of its interaction with a film of the liquid which is flowing down on its external surface. In this case the method of extrusion of a tubular polymeric film with blowing according to the scheme "from top to down" is the most expedient (unlike air cooling when the scheme "from below up" is the most acceptable).

However for the analysis of efficiency of process of cooling of the tubular blown polymeric film with a gravitational film of liquid it is necessary to investigate hydrodynamics of the liquid film which is flowing down on the moving firm surface and also heat exchange between them.

\section{Literature review and research problems}

The main stages of technology influencing quality of tubular blown polymeric packing films are processes of preparation of polymer melt in an extruder, a blowing of workpiece of the polymeric tubular film at the exit from an extruder die, and also cooling of the overblown polymeric tubular film.

The analysis of publications on a problem of production of tubular blown polymeric films showed that the majority of them is devoted to numerical and experimental modeling of separate stages of process of their production. At the same time the main attention is paid to process of preparation of polymer melt in the extruder [5-9], to process of a shaping of a polymer film bubble (the overblown polymer tubular film) [1], and also process of cooling of the formed polymer film bubble with a stream of air [10].

For example, in work [11] production process, and also rheological properties of fusion and tubular blown films of the polypropylene filled with various nanoparticles are in detail considered. At the same time the formed tubular blown film was cooled on air.

The mathematical model of not isothermal process of a shaping of a tubular blown polymeric film is given in work [12]. The analysis of average temperature of a tubular blown film from the low density polyethylene and axial tension arising in it in the course of a blowing is made. Cooling of a film is considered at its contact with air.

In work [13] properties of a tubular blown film from linear low density polyethylene with an additive of hyperbranched polymer are investigated. The produced films differ in high quality of a surface with high operational properties. The studied films were produced by means of a single screw extruder with a diameter of screw of $25 \mathrm{~mm}$ and the relation of length of the screw to its diameter 25:1. Cooling of a polymer bubble was carried out by an air stream.

Work [14] investigates properties of a tubular blown packing film from polyvinyl acetate with nanoparticles of starch. The polymeric film was made on a single screw extruder with a diameter of screw of $35 \mathrm{~mm}$; screw long 25 times more of its diameter and extent of compression 1:3. The polymer bubble after its blowing was cooled on air.

Features of traditional technology of a tubular blown polymeric film on the basis of 
starch are also considered in works $[15,16]$.

In work [17] process of blowing and dynamics of further destruction of a biodegradable tubular blown polymeric packing film on the basis of low density polyethylene are considered. Cooling of the film after its blowing it is also carried out on air.

Results of research of process of production of a biodegradable tubular blown film, and also physical-mechanical properties of this film are considered in work [18]. Production of the film in this work is also considered by the method "from below up" with cooling of the film on air. Results of similar researches for a biodegradable tubular blown film on the basis of Polylactic acid are given in work [19].

Results of researches of process of orientation at production of tubular blown films from various types of polyethylene are given in work [20]. Anisotropy of the films produced by an extrusion method with their further cooling on air is also considered. Results of similar researches are given also in work [21].

Possibilities of a blowing of tubular films from polyethylene and polypropylene are considered in work [22].

In work [23] rheological aspects of process of a shaping of a polymer bubble with its further cooling on air are in detail investigated.

Similar problems are also considered in works [24-28].

Works $[1,29]$ present results of mathematical modeling of process of cooling of tubular polymeric products in a liquid stream. However the models given in these works are not suitable for the analysis of process of cooling with the flowing-down liquid film.

Directly the problem of cooling of polymeric films is considered in work [30]. However these researches concern cooling to a flat polymeric film on the drum which is partially shipped in a water bath. And results of mathematical modeling of process of cooling of a tubular polymeric film by the flowing-down liquid film are given in work [31]. At the same time the analysis only of results of mathematical modeling of the temperature field of epy polymeric film is made and stability of the polymer bubble and a liquid film in this work were not considered.

The hydrodynamics and heat exchange of the flowing-down water film at its boiling on a motionless vertical surface are investigated in work [32].

The majority of the settlement dependences of process of heat exchange which are available in literature with participation of the flowing-down film of liquid are suitable for motionless horizontal or vertical surfaces [33] that makes impossible carrying out the analysis of process of film cooling for a mobile vertical surface.

As we see, the majority of researches of the last years concern the analysis of properties of new polymeric compositions and films with their use. At the same time results of researches of process of cooling of a tubular polymeric film with the liquid film which is flowing down on it are practically absent. Therefore researches of process of liquid cooling of hose polymeric packing films is actual.

The objective of the study is the analysis of process of cooling of tubular blown polymeric packing films the flowing-down liquid film. It will allow to determine rational parameters of process of cooling (type of cooling liquid, its temperature and a volume discharge, and also cooling zone length) for cooling of a polymeric film up to the required temperature in a definite time.

It is necessary to solve the following tasks to achieve the objective:

- theoretical investigation the liquid concentration size providing a condition of balance of forces, acting on a polymer bubble at its cooling with the flowing-down liquid film; 
- experimentally confirm a possibility of practical realization of process of liquid cooling of tubular blown polymeric films;

- formulate recommendations about rational realization process of cooling of tubular blown polymeric packing films with the flowing-down liquid film.

\section{Materials and methods}

\section{Materials}

As material of the studied polymeric films low density polyethylene (LDPE) of two types was used:

- LDPE, type 1; density is $919.0 \mathrm{~kg} / \mathrm{m}^{3}$; melt flow index of $2 \mathrm{~g} / 10 \mathrm{~min}$ at a temperature of $190{ }^{\circ} \mathrm{C}$ and load of $21.17 \mathrm{~N}$;

- LDPE, type 2; density is $920.5 \mathrm{~kg} / \mathrm{m}^{3}$; melt flow index of $0.3 \mathrm{~g} / 10 \mathrm{~min}$ at a temperature of $190^{\circ} \mathrm{C}$ and load of $21.17 \mathrm{~N}$.

The studied samples of a polymeric film produced the next way.

The film sample by the sizes $1000 \times 320 \times 0.1 \mathrm{~mm}$ (along the polymer bubble) was cut out from the polymer bubble in folded form produced on experimental-industrial working plant. Then the long parties of a sample of the film fixed on a similar film substrate by means of steel wires with a diameter of $0.5 \mathrm{~mm}$. Then the film substrate in horizontal position had on the flat electric heater. In the middle of the made package from one of its short parties between a sample of the film and the film substrate placed jumped to thickness of $0.1 \mathrm{~mm}$ thermojunction. After that at a temperature of $180^{\circ} \mathrm{C}$ the prototype of the film and the film substrate were welded among themselves. As a result received a monofilm 0.2 mm thick with sealed in its center (on thickness) the thermocouple.

Samples of a polymeric film of other thickness were similarly made.

\section{Experimental installation}

Authors developed the experimental stand for research of process of heat exchange at a film current of liquid on a mobile polymeric surface. Also experimental-industrial installation (working plant) was developed for production of a tubular blown polymeric film with liquid cooling on which operating modes of formation of the polymer bubble and a design of the liquid cooling system were fulfilled.

Basic elements of the experimental stand are a head for distribution of the liquid film and the studied flat sample of a polymeric film.

The head is executed in the form of the plane-parallel slot-hole distributor with regulation of distance between sponges (within $0.4 \ldots 0.8 \mathrm{~mm}$ ) and slot of $300 \mathrm{~mm}$ wide. At the same time as cooling liquid the tap water which is previously purified by means of the filter with a temperature of $15 \ldots 40{ }^{\circ} \mathrm{C}$ was used. Regulation of water temperature was carried out by means of the heat exchanger supplied with resistance electric heaters. The volume flow rate of water was regulated the valve, and measured by the rotameter. Also after each experience carried out control measurement of volume of water by a volume method by means of a measured vessel and a stop watch. Water temperature on an entrance and an exit of the studied sample of the polymeric film was measured by the thermocouples installed in the camera of a distributive head and before a reception funnel.

The prototype of the polymeric film with a film substrate the long parties was fixed on 
links of two vertically located infinite chains which covered driving and tension asterisks of the pulling device. At the same time the thermocouple of the film sample was connected to measuring equipment. The run of the film was carried out from the reversive electric motor. The film run in the vertical direction was limited to two limit switches. The working film run - vertical from top to bottom with the regulated speed $(0.03-0.50 \mathrm{~m} / \mathrm{s})$, and idle run from below up with a constant speed.

Heating of the polymeric film prototype was carried out thermal radiation from the thermal screen the size $0.3 \times 1,0 \mathrm{~m}$ supplied with the flat electric heater of resistance. Temperature of the screen was maintained automatically by means of the device of thermal automatic equipment. For providing the "soft" mode of heating of the sample it was carried out not only regulations of power of the electric heater of the screen, and distance between the screen and the sample.

Steel wires at the edges of the double thickness monofilm during experience played a role of peculiar thresholds, providing at the same time a current of the liquid film, uniform on sample width.

Research was conducted in the following sequence.

By means of chains the sample of the polymeric film is established in extreme top point (at the same time the top limit switch works). After that the necessary mode of heating of epy film with the thermal screen before achievement by a sample of epy polymeric film of necessary temperature was provided.

Then the necessary volume flow rate of water of a certain temperature which at the exit from a head in the form of a flat film flew down on the motionless directing plate established under a sample of the polymeric film and at last got to a reception funnel was provided.

After that the drive of the pulling device was switched on. At the same time chains with the set speed moved the polymeric film sample concerning the distributor of a water film, the sample began to contact to water and was gradually cooled, the lower limit switch of the stand did not work yet. During the movement of the studied sample of a polymeric film the thermogram of its cooling continuously registered.

Thus, at the experimental stand it was possible to conduct numerous researches of cooling process of a certain sample of the polymeric film under various conditions: a volume flow rate of the cooling water, its initial temperature, and also speed of the movement of the sample of the polymeric film.

Experimental-industrial installation for production of the tubular blown polymeric film is developed on the basis of the line for production of a tubular blown film according to the scheme "from above-down". Installation consists of a single screw extruder, an extrusive ring die with the central feeding of melt below which the ring for formation of the water film on an external surface of the polymer bubble is located. For elimination of possible cross fluctuations of the polymer bubble below the liquid distributive ring the stabilizing device with system of the rollers made of a polytetrafluorethylene (teflon) which evenly on a circle contact to the bubble is mounted. Under these device it is mounted the putting and pulling devices executed in the form of two cheeks located at an angle to each other and two rubberized rolls, respectively (Figure 1). 


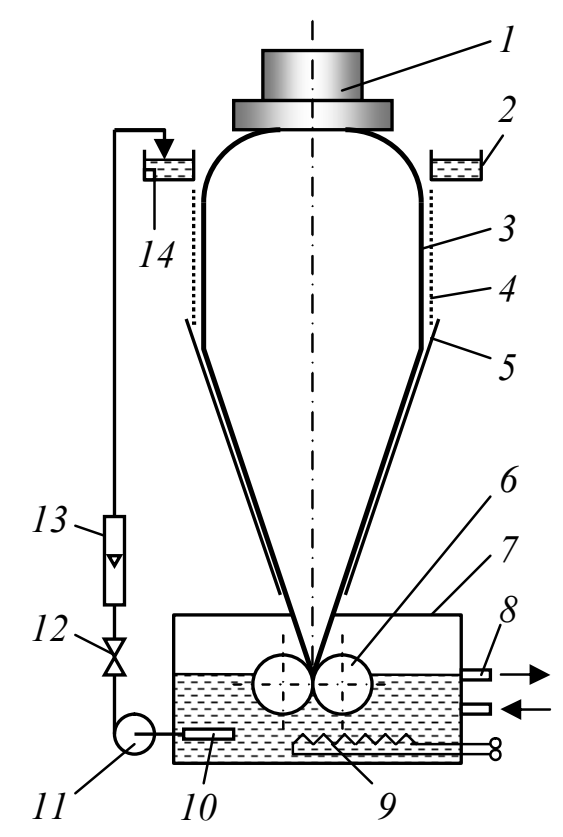

Figure 1. Experimental-industrial installation for production of the tubular blown polymeric film:

1 - extruder ring film die; 2 - the film cooling system with a distributive ring; 3 - tubular blown polymeric film; 4 - film of cooling water; 5 - the putting cheeks; 6 - the pulling rolls; 7 - bathtub for water reception; 8 - drain branch pipe for maintenance of water level in the bathtub; 9 - electrical heater; 10 - filter; 11 - pump; 12 - regulating valve; 13 - rotameter; 14 - resistance thermometer

On the made experimental-industrial installation (working plant) a number of experiments on production of tubular blown films from LDPE in the wide range of values of productivity of the extruder, volume flow rate and reference temperature of the cooling water, and also film thickness depending on conditions of production of the polymeric film was carried out.

\section{Mathematical modeling}

Earlier authors developed mathematical model of process of liquid cooling of the tubular blown polymeric film [31]. This model contains the equations of the movement and continuity for the liquid film current by gravity, the equations of conservation of energy for the polymeric film and the liquid film, and also the corresponding initial and boundary conditions on the speed and temperature.

The developed model allows for the set film speed (extruder productivity) and parameters of the film to determine length of a cooling zone or for the set length of a cooling zone to determine the maximum speed of the film with the set parameters. 


\section{Results and discussion}

\section{Theoretical researches}

For determination of design and technological data of cooling process of the tubular blown polymeric film we will consider balance of forces, acting on the polymer bubble limited to two sections: melt exit section from a ring extrusive die and section through contact of the pulling rolls (Figure 2):

$$
\vec{F}_{0}+\vec{P}+\vec{G}+\vec{P}_{\mathrm{w}}+\vec{F}_{\mathrm{r}}+\vec{F}_{\mathrm{fp}}+\vec{F}_{\mathrm{fw}}=0
$$

where $\vec{F}_{0}$ is the viscoelastic stretching force operating in the bubble basis (it is result of action of other forces applied to the bubble), N; $\vec{P}$ is force from action of pressure of air inside the bubble, N; $\vec{G}$ is weight of the bubble, N; $\vec{P}_{\mathrm{w}}$ is force of a high-speed pressure of a stream of liquid at the exit from the distributing device of a liquid film, N; $\vec{F}_{\mathrm{r}}$ is bubble stretching force from the pulling rolls, $\mathrm{N} ; \vec{F}_{\mathrm{fp}}$ is bubble friction force on cheeks of the putting device, $\mathrm{N} ; \vec{F}_{\mathrm{fw}}$ is friction force between the polymer bubble and a film of liquid, $\mathrm{N}$.

Let's write down dependence (1) in projections to a longitudinal axis of the bubble

$$
F_{0}+P-G-P_{\mathrm{w}} \cos \gamma-F_{\mathrm{r}}+F_{\mathrm{fp}}-F_{\mathrm{fw}}=0 .
$$

Now we will consider each of components of dependence (2).

The viscoelastic stretching force operating on the bubble basis

$$
F_{0}=2 \pi r_{0} \delta_{0} \sigma_{0}
$$

where $r_{0}$ and $\delta_{0}$ are initial radius and initial thickness of the polymeric tubular workpiece (initial polymer bubble) at the exit from the extrusive die, respectively, $\mathrm{m} ; \sigma_{0}$ is the longitudinal tension of stretching in the bubble at the exit from an extrusive die, $\mathrm{Pa}$.

Force from action of pressure of air in the bubble is

$$
P=\pi\left(r_{\mathrm{s}}^{2}-r_{0}^{2}\right) \Delta p
$$

where $\mathrm{r}_{\mathrm{s}}$ is bubble radius after its blowing, $\mathrm{m} ; \Delta p$ - excessive pressure in the bubble, $\mathrm{Pa}$.

The weight of the polymer bubble is equal

$$
G=G_{1}+G_{3}+G_{3},
$$

where $G_{1}$ is weight the bubble on the blowing zone, $\mathrm{N} ; G_{2}$ is weight of the bubble of a cylindrical form on the zone from the place of contact of the bubble with liquid to the zone of folding of the bubble, $\mathrm{N} ; G_{3}$ is bubble weight on the zone from the place of folding of the bubble to the pulling rolls, $\mathrm{N}$. 


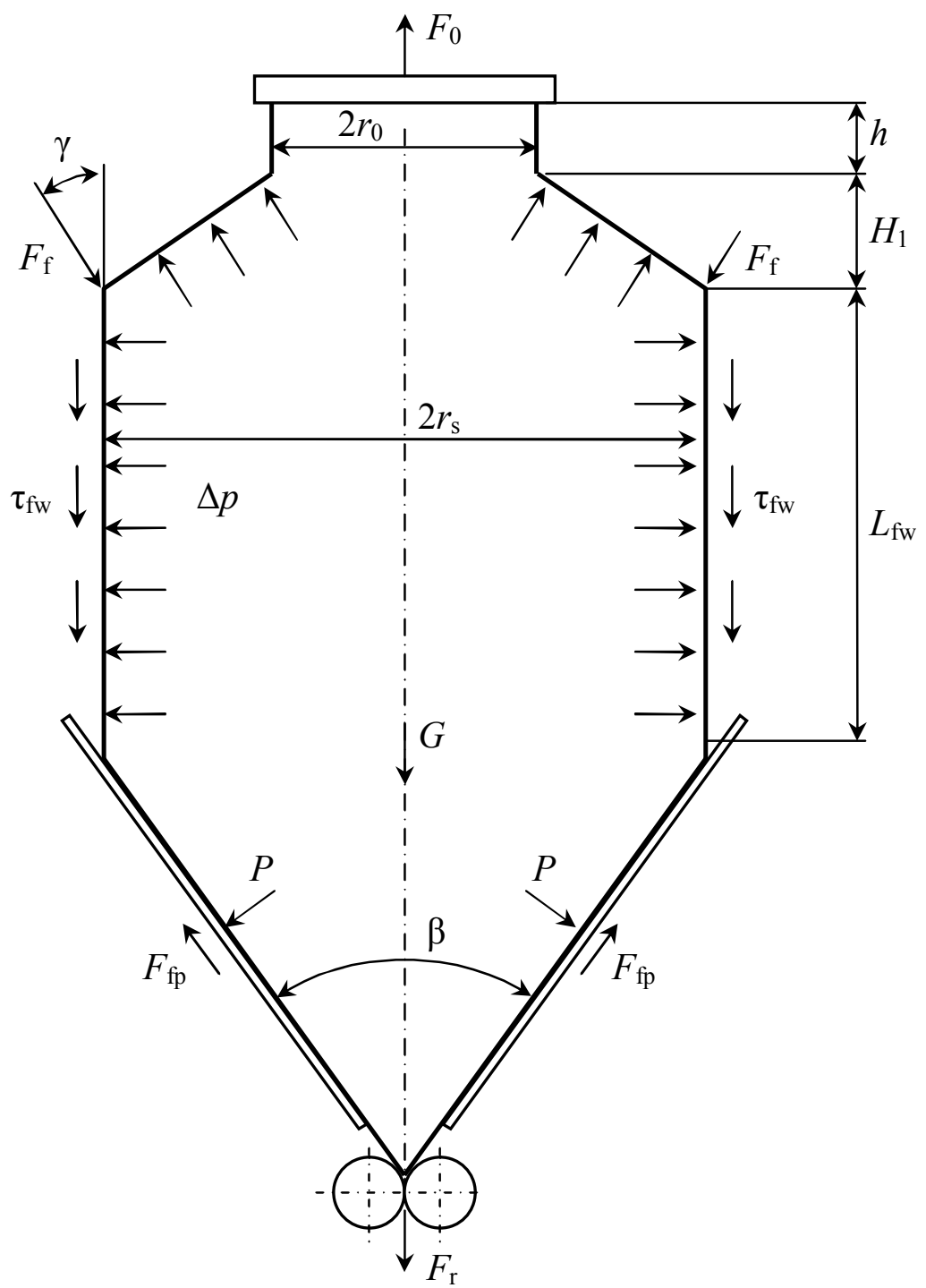

Figure 2. The scheme of forces operating on the polymer bubble at liquid cooling (explanations in the text)

Let's analyze the components of formula (3).

Bubble weight on the blowing zone is [1]

$$
G_{1}=2 \pi r_{0} \delta_{0} \rho g\left(\frac{v_{0}}{v_{\mathrm{s}}-v_{0}}\left(H_{1}-h\right) \ln \frac{v_{\mathrm{s}}}{v_{0}}+h\right),
$$

where $\mathrm{g}$ is acceleration of gravity, $\mathrm{m} / \mathrm{s}^{2} ; v_{0}$ is speed of tubular workpiece at the exit from the extrusive die, $\mathrm{m} / \mathrm{s} ; v_{\mathrm{s}}$ is speed of the formed bubble at the exit from the blowing zone, $\mathrm{m} / \mathrm{s} ; H_{1}$ is 
distance from the beginning of blowing zone prior to contact of the bubble with liquid (the blowing zone), $\mathrm{m} ; h$ is distance from the extrusive die prior to the beginning of blowing zone, $\mathrm{m}$.

Taking into account practice of production of tubular polymeric films their stability during cooling with the film of liquid is maximum in a case when $h=0$. Then dependence (4) takes a form

$$
G_{1}=2 \pi r_{0} \delta_{0} H_{1} \rho g\left(\frac{v_{0}}{v_{\mathrm{s}}-v_{0}} \ln \frac{v_{\mathrm{s}}}{v_{0}}\right)
$$

The weight of the cylindrical part of the bubble on the zone from the place of contact of the bubble with liquid to the zone of folding of the bubble

$$
G_{2}=2 \pi r_{\mathrm{s}} \delta_{\mathrm{s}} \rho g L_{\mathrm{fw}}
$$

where $\delta_{\mathrm{s}}$ is bubble thickness after its blowing, $\mathrm{m}$; $L_{\mathrm{fw}}$ is length of the continuous liquid film flow zone, $\mathrm{m}$.

Bubble weight on the zone from the place of the bubble folding to the pulling rolls

$$
G_{3}=2 \pi r_{\mathrm{s}}^{2} \delta_{\mathrm{s}} \rho g \operatorname{ctg} \frac{\beta}{2}
$$

where $\beta$ is angle of folding of the polymer bubble.

Taking into account expressions (5)-(7) dependence (3) will equal

$$
G=2 \pi r_{0} \delta_{0} H_{1} \rho g\left(\frac{v_{0}}{v_{\mathrm{s}}-v_{0}} \ln \frac{v_{\mathrm{s}}}{v_{0}}\right)+2 \pi r_{\mathrm{s}} \delta_{\mathrm{s}} \rho g\left(L_{\mathrm{fw}}+r_{\mathrm{s}} \operatorname{ctg} \frac{\beta}{2}\right)
$$

Force of a high-speed pressure of a ring liquid stream

$$
P_{\mathrm{w}}=\pi r_{\mathrm{s}} H \rho_{\mathrm{w}} \bar{U}^{2},
$$

where $H$ is width of slot of the distributive ring of liquid, m, $\mathrm{m} ; \rho_{\mathrm{w}}$ is density of liquid, $\mathrm{kg} / \mathrm{m}^{3}$; $\bar{U}$ is average speed of liquid in a point of contact with the polymer bubble, $\mathrm{m} / \mathrm{s}$.

Friction force between the polymer bubble and the liquid film is

$$
F_{\mathrm{fw}}=S_{\mathrm{fw}} \tau_{\mathrm{fw}},
$$

where $S_{\mathrm{fw}}$ is surface area of the polymer bubble length $L_{\mathrm{fw}}$ (from the place of the beginning of contact of the bubble with liquid to the place of a rupture of the continuous ring film of liquid on separate streams), $\mathrm{m} ; \tau_{\mathrm{fw}}$ is tangent tension on contact border "polymer - liquid", $\mathrm{Pa}$

$$
\tau_{\text {wall }}=g \bar{\delta} \rho_{\mathrm{w}}
$$

where $\bar{\delta}$ is average thickness of the liquid film of on the zone of its steady current length $L_{\mathrm{fw}}$, m. 
We will determine the average thickness of the liquid film on the zone by length $L_{\mathrm{fw}}$ from dependence [34]

$$
\bar{\delta}=0,457\left(\frac{v_{w}^{2}}{g}\right)^{\frac{1}{3}}[\operatorname{Re}(1 \pm \Pi)]^{0,36} \quad \text { if } \operatorname{Re}(1 \pm \Pi)>1600
$$

where $v_{\mathrm{w}}$ is kinematic viscosity of liquid, $\mathrm{m}^{2} / \mathrm{s} ; \Pi=U_{0} / \bar{U}-$ the simplex considering the relative speed of the liquid film; $U_{0}$ is speed of the polymer bubble, $\mathrm{m} / \mathrm{s} ; \bar{U}$ is average speed of a current of the liquid film on the zone length $L_{\mathrm{fw}}$, which is equal to the average speed of liquid in a point of initial contact with the polymer bubble, $\mathrm{m} / \mathrm{s}$.

As the volume fluid flow rate is to constants (losses on evaporation in environment we neglect), taking into account expression for irrigation density $\Gamma_{V}=\bar{U} H$ the component of a high-speed pressure takes a form

$$
P_{\mathrm{w}}=\pi r_{\mathrm{s}} b_{\mathrm{w}} \rho_{\mathrm{w}} \bar{U}^{2} \cos \gamma=\frac{\pi r_{\mathrm{s}} \rho_{\mathrm{w}} \Gamma_{V}^{2} \cos \gamma}{H},
$$

where $b_{\mathrm{w}}$ is liquid stream width at the beginning of contact with the bubble, $\mathrm{m}$ (with an accuracy, sufficient for engineering calculations, it is possible to accept that $b_{\mathrm{w}}=H$ ).

Bubble friction force on cheeks of the putting device $F_{\mathrm{fp}}$ depends on pressure in the bubble, coefficient of friction of polymer on material of cheeks at this temperature and the area of contact of the bubble with cheeks.

In the analysis of dependence (2) practical value has a case when polymer melt is extended not by effort from the pulling rolls, and a body weight and force of a high-speed pressure of the liquid stream $F_{\mathrm{w}}$.

Let's assume that $F_{\mathrm{r}}=F_{\mathrm{fp}}$, then dependence (2) takes a form

$$
F_{0}+\pi\left(r_{\mathrm{s}}^{2}-r_{0}^{2}\right) \Delta p-G-g \bar{\delta} \rho_{\mathrm{w}} S_{\mathrm{fw}}-\pi r_{\mathrm{s}} H \rho_{\mathrm{w}} \bar{U}^{2} \cos \gamma=0
$$

Then taking into account the given dependences expression (8) will have an appearance

$$
\begin{aligned}
& -g \rho_{\mathrm{w}} S_{\mathrm{fw}}\left(\frac{3 v_{\mathrm{w}}^{2}}{4 g}\right)^{\frac{1}{3}}\left[\frac{4 \Gamma_{V}}{v_{\mathrm{w}}} \operatorname{Re}(1+\Pi)\right]^{\frac{1}{3}}-\frac{2 \pi r_{\mathrm{s}} \rho_{\mathrm{w}} \Gamma_{V}^{2} \cos \gamma}{H}= \\
& =0-g \rho_{\mathrm{w}} S_{\mathrm{fw}}\left(\frac{3 v_{\mathrm{w}}^{2}}{4 g}\right)^{\frac{1}{3}}\left[\frac{4 \Gamma_{V}}{v_{\mathrm{w}}} \operatorname{Re}(1+\Pi)\right]^{\frac{1}{3}}-\frac{2 \pi r_{\mathrm{s}} \rho_{\mathrm{w}} \Gamma_{V}^{2} \cos \gamma}{H}=0
\end{aligned}
$$

In case of supply of liquid on a normal to a longitudinal axis of the polymer bubble that usually takes place in practice, the component of a high-speed stream of a pressure of liquid becomes equal to zero. Then taking into account that $S_{\mathrm{fw}}=2 \pi r_{\mathrm{s}} L_{\mathrm{fw}}$ the equation of balance of forces (9) will finally take a form 


$$
\begin{aligned}
& -2 \pi r_{\mathrm{s}} \delta_{\mathrm{s}} \rho g\left(L_{\mathrm{fw}}+r_{\mathrm{s}} \operatorname{ctg} \frac{\beta}{2}\right)-2 \pi r_{\mathrm{s}} g \rho_{\mathrm{w}} L_{\mathrm{fw}}\left(\frac{3 v_{\mathrm{w}}^{2}}{4 g}\right)^{\frac{1}{3}}\left[\frac{4 \Gamma_{V}}{v_{\mathrm{w}}} \operatorname{Re}(1+\Pi)\right]^{\frac{1}{3}}= \\
& =0-2 \pi r_{\mathrm{s}} \delta_{\mathrm{s}} \rho g\left(L_{\mathrm{fw}}+r_{\mathrm{s}} \operatorname{ctg} \frac{\beta}{2}\right)-2 \pi r_{\mathrm{s}} g \rho_{\mathrm{w}} L_{\mathrm{fw}}\left(\frac{3 v_{\mathrm{w}}^{2}}{4 g}\right)^{\frac{1}{3}}\left[\frac{4 \Gamma_{V}}{v_{\mathrm{w}}} \operatorname{Re}(1+\Pi)\right]^{\frac{1}{3}}=0
\end{aligned}
$$

From dependence (10) define the value of volume cooling water concentration $\Gamma_{V}$, satisfying the condition of balance of forces (1) in the process of liquid cooling of the polymer bubble.

From dependence (10) critical values of volume cooling water concentration for tubular films of a different standard size from LDPE were defined. As in the specified dependence unknown sizes are both $\Gamma_{V}$, and $L_{\mathrm{fw}}$, which in turn depends on $\Gamma_{V}$, calculations carried out by method of consecutive approximations.

On critical values of volume cooling water concentration $\Gamma_{V}$ counted the volume productivity of the technological line $q$ (or the speed of an exit of polymer melt from the extrusion die $v_{0}$ ) from the condition of achievement of necessary temperature on an internal surface of the polymer bubble.

The nomogram for determination of volume cooling water concentration, and also volume productivity of the technological polymeric film line depending on geometrical parameters of a ready polymer bubble is given in Figure 3.

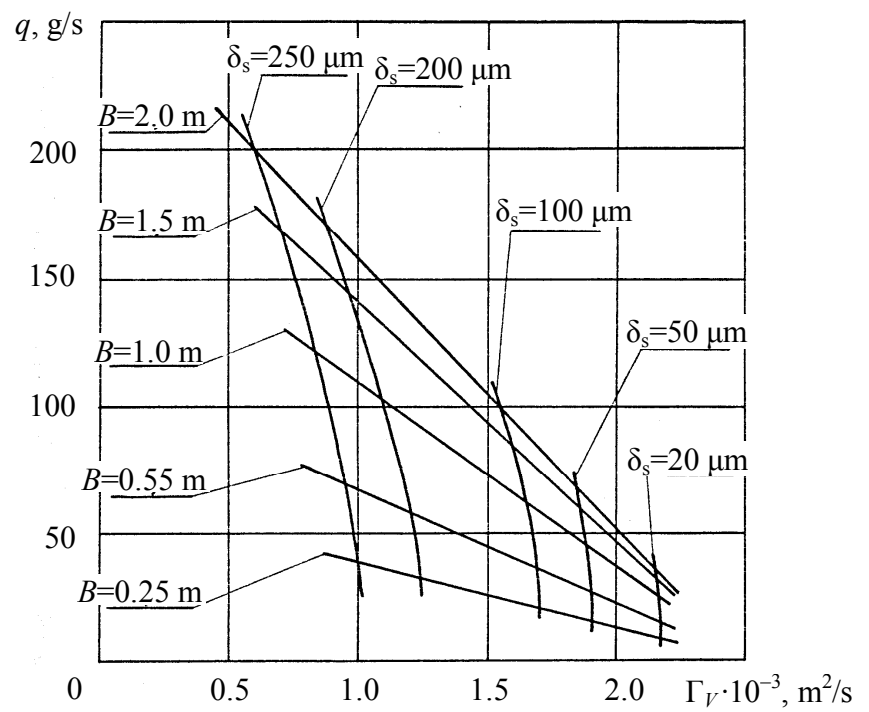

Figure 3. The nomogram for determination of extreme values of volume liquid concentration $G_{V}$ and productivity of the technological line $q$ from the geometrical sizes of the tubular blown polymeric film (film thickness $\delta_{\mathrm{K}}$ and width of polymer bubble in folded form $B$ )

As a result of theoretical researches of process of cooling of extruded tubular polymeric films with the flowing-down water film it is established that at the liquid concentration $\left(\Gamma_{V} \geq 5.03 \cdot 10^{-3} \mathrm{~m}^{2} / \mathrm{s}\right.$, or $\left.\operatorname{Re} \geq 20000\right)$ arise essential power load of the polymer bubble. Besides, at such high liquid concentration only the wall layer of liquid 
participates in heat exchange that leads to its over-expenditure.

Therefore when carrying out parametrical calculations it is necessary to define critical value of volume liquid concentration which can sustain the polymer bubble of a certain diameter and thickness.

Apparently from nomogram given on Figure 3, the greatest effect of liquid cooling can be reached at production of films with a width of the bubble in folded form to $1 \mathrm{~m}$.

\section{Experimental researches}

Parameters of processes of production of tubular blown films of LDPE (types 1 and 2) on experimental-industrial working plant are specified in Table 1.

Table 1

Parameters of processes of production of tubular blown films of LDPE of 1 type and type 2 (in brackets)

\begin{tabular}{|l|c|c|}
\hline \multicolumn{1}{|c|}{ Parameter } & $\begin{array}{c}\text { Unit of measure of } \\
\text { physical quantity }\end{array}$ & $\begin{array}{c}\text { Absolute value of physical } \\
\text { quantity }\end{array}$ \\
\hline Mass productivity of installation & $\mathrm{g} / \mathrm{s}$ & $\begin{array}{c}17.3-69.4 \\
(16.2-68.3)\end{array}$ \\
\hline $\begin{array}{l}\text { Speed of the movement of the } \\
\text { polymer bubble (stretching speed })\end{array}$ & $\mathrm{m} / \mathrm{s}$ & $0.07-0.5$ \\
\hline $\begin{array}{l}\text { Width of the polymer bubble in } \\
\text { folded form }\end{array}$ & $\mathrm{m}$ & $0.25 ; 0.5$ \\
\hline Thickness of the polymeric film & $\mathrm{mm}$ & $0.06-0.2$ \\
\hline $\begin{array}{l}\text { Melt temperature at the exit from an } \\
\text { extrusive die }\end{array}$ & ${ }^{\circ} \mathrm{C}$ & 180 \\
\hline $\begin{array}{l}\text { Volume consumption of the cooling } \\
\text { water }\end{array}$ & $10^{3} \mathrm{~m}^{3} / \mathrm{s}$ & $0.25-0.92$ \\
\hline Volume water concentration & $10^{3} \mathrm{~m}^{2} / \mathrm{s}$ & $0.35-0.88$ \\
\hline $\begin{array}{l}\text { Initial temperature of the cooling } \\
\text { water }\end{array}$ & ${ }^{\circ} \mathrm{C}$ & $20-60$ \\
\hline $\begin{array}{l}\text { Length of the zone of the continuous } \\
\text { current of the liquid film }\end{array}$ & $\mathrm{m}$ & $0.15-0.8$ \\
\hline $\begin{array}{l}\text { Width of the ring slot of water } \\
\text { supply }\end{array}$ & $\mathrm{m}$ & $0.4-0.8$ \\
\hline
\end{tabular}

Follows from table 1 that length of a zone of liquid cooling of the polymer bubble does not exceed $1 \mathrm{~m}$ while length of a zone of traditional air cooling of the polymer bubble can reach several meters [1].

Physical-mechanical properties of the tubular blown polymeric film from PEVD, type 2 , received at liquid cooling are given in Table 2 . 
Table 2

Physical-mechanical properties of the tubular blown polymeric film from LDPE, type 2

\begin{tabular}{|c|c|c|c|c|c|}
\hline \multirow{2}{*}{$\begin{array}{c}\text { Sample } \\
\text { No }\end{array}$} & \multicolumn{2}{|c|}{$\begin{array}{c}\text { Ultimate strength of the } \\
\text { film, MPa }\end{array}$} & \multicolumn{2}{|c|}{ Tensile strain, \% } & \multirow{2}{*}{$\begin{array}{c}\text { Temperature of } \\
\text { the cooling } \\
\text { water, }{ }^{\circ} \mathbf{C}\end{array}$} \\
\cline { 2 - 5 } & along & across & along & across & 20 \\
\hline 1 & 20.1 & 18.9 & 458 & 508 & 60 \\
\hline 2 & 20.6 & 18.5 & 432 & 500 & 40 \\
\hline 3 & 20.3 & 18.6 & 440 & 512 & 50 \\
\hline 4 & 19.8 & 18.1 & 453 & 497 & 60 \\
\hline 5 & 20.9 & 19.3 & 439 & 506 & \\
\hline
\end{tabular}

Further researches of cooling process of the film were conducted at a temperature of cooling water of $20{ }^{\circ} \mathrm{C}$ which corresponds to the average temperature of cold water in a water supply system.

Also influence of a ratio of length of the bubble blowing zone (distance $L_{\mathrm{ws}}$ from the extrusive die to the line of contact of cooling liquid with the polymer film bubble) and diameter of the bubble $D_{\mathrm{s}}$ on process of formation of the film on condition of ensuring stability and stability of liquid cooling was investigated.

It is shown that under a condition $L_{\mathrm{ws}} / D_{\mathrm{s}}<0.5$ on the bubble blowing zone has the parabolic form (a convex form), under a condition $0.5 \leq L_{\mathrm{ws}} / D_{\mathrm{s}} \leq 1,0-$ conic, and under a condition $L_{\mathrm{ws}} / D_{\mathrm{s}}>1.0$ - the neck is formed (a concave form). At the same time it is proved that the bubble with a parabolic form blowing zone the steadiest, and the films received thus are characterized by a minimum of anisotropy of properties.

Results of researches of physical-mechanical properties of the tubular blowing film at the following data are given in Table 3: diameter $-350 \mathrm{~mm}$, blowing degree -1.4 , the mass productivity of the extruder $-16 \mathrm{~g} / \mathrm{s}(57.6 \mathrm{~kg} / \mathrm{h})$. Apparently from tab. 3 , length of the blowing zone (or the ratio $L_{\mathrm{ws}} / D_{\mathrm{s}}$ ) insignificantly influences physical-mechanical properties of the produced film, however, as it was specified, with increase $L_{\mathrm{ws}} / D_{\mathrm{s}}$ stability of process of a shaping of the film is broken.

Table 3

Physical-mechanical properties of the film depending on length of a blowing zone

\begin{tabular}{|c|c|c|c|c|}
\hline \multirow{2}{*}{$L_{\text {ws }} / D_{\mathrm{s}}$} & \multicolumn{2}{|c|}{ Ultimate strength of the film, MPa } & \multicolumn{2}{c|}{$\begin{array}{c}\text { Tensile strain, } \\
\%\end{array}$} \\
\cline { 2 - 5 } & along & across & along & across \\
\hline 0.343 & 22.7 & 22.5 & 750 & 775 \\
\hline 0.429 & 22.1 & 22.0 & 762 & 785 \\
\hline 0.600 & 22.8 & 22.6 & 770 & 735 \\
\hline 0.857 & 21.0 & 22.1 & 745 & 780 \\
\hline
\end{tabular}

Results of numerical modeling of process of cooling of the tubular blown polymeric film with the flowing-down film of liquid [31] showed satisfactory compliance to data of experimental researches. 


\section{Conclusion}

The following conclusions can be drawn, based on the obtained results:

1. Parameters of the liquid film (a speed profile, film thickness) change only on an entrance zone and depend on density of liquid concentration of the polymer bubble and initial distribution of speed of the liquid film at the exit from a distributive ring.

2. At the high values of liquid concentration providing the developed turbulent mode of a current of the liquid film (Reynolds number over 20000), only the wall layer of liquid participates in heat exchange.

3. For the film from LDPE its external surface hardens at distance about $0.01 \mathrm{~m}$ from the beginning of contact with water, and an internal surface - at distance about $0.10-0.15$ $\mathrm{m}$. Therefore the ring for distribution of liquid needs to be established after the termination of a blowing zone of the polymeric tubular workpiece. It is also necessary to provide the steady movement of a continuous liquid film on an external surface of a polymeric tube on length to $0.2 \mathrm{~m}$ from the beginning of contact of liquid from the polymeric film.

4. For thick films from LDPE (thickness more than $200 \mu \mathrm{m}$ ) and over $1 \mathrm{~m}$ wide intensity of cooling is limited to the critical liquid concentration.

5. For practical application of the received results the nomogram for determination of volume liquid concentration of the cooling water, and also volume productivity of the technological line depending on the sizes of a ready tubular blown polymeric film is offered.

6. Temperature of the cooling water in the range of $20-60{ }^{\circ} \mathrm{C}$ significantly does not influence both intensity of cooling process, and physical-mechanical properties of the produced polymeric film.

7. Extreme values of degree of the polymer bubble blowing $\left(K_{\mathrm{b}}=2\right)$ and degree of stretching $\left(K_{\mathrm{s}}=4\right)$ from LDPE are established. It is shown that the limiting stage in production of thin films (thickness of $40 \mu \mathrm{m}$ and less) with a speed of receiving not less than $0.5 \mathrm{~m} / \mathrm{s}$ is not process of cooling, and physical-mechanical properties of the film (in particular anisotropy of its properties).

The obtained results of researches allow to determine rational parameters of technological processes of producing tubular blown polymeric films.

\section{References}

1. Lukach Yu. E., Petuhov A. D., Senatos V. A. (1981), Oborudovanie dlya proizvodstva polimernykh plenok, Equipment for production of polymeric films, Mashinostroenie, Moscow (in Russian).

2. Tadmor Z., Gogos C. G. (2006), Principles of polymer processing, John Wiley \& Sons, Inc., New Jersey.

3. Rauwendaal C. (2014), Polymer extrusion, Carl Hanser Verlag, Munich, DOI: $10.3139 / 9781569905395$

4. Mikulionok I. O. (2015), Classification of Processes and Equipment for Manufacture of Continuous Products from Thermoplastic Materials, Chemical and Petroleum Engineering, 51(1-2), pp. 14-19, doi: 10.1007/s10556-015-9990-6 
5. Mikulionok I. O., Radchenko L. B. (2012), Screw extrusion of thermoplastics: I. General model of the screw extrusion, Russian Journal of Applied Chemistry, 85(2), pp. 489-504, doi: $10.1134 / \mathrm{s} 1070427211030305$

6. Mikulionok I. O., Radchenko L. B. (2012), Screw extrusion of thermoplastics: II. Simulation of feeding zone of the single screw extruder, Russian Journal of Applied Chemistry, 85(3), pp. 505-514, DOI: 10.1134/s1070427211030317

7. Mikulionok I., Gavva O., Kryvoplias-Volodina L. (2018), Modeling of melting process in a single screw extruder for polymer processing, Eastern-European Journal of Enterprise Technologies, 2/5(92), pp. 4-11, DOI: 10.15587/1729-4061.2018.127583

8. Mikulionok, I. O. (2013), Screw extruder mixing and dispersing units, Chemical and Petroleum Engineering, 49(1-2), pp. 103-109, DOI: 10.1007/s10556-013-9711-y

9. Vytvytskyi V., Mikulionok I., Sokolskyi O., Gavva O. (2017), Pressure and temperature influence on the friction coefficient of granular polymeric materials on the metal surfaces, Ukrainian Food Journal, 6(3), pp. 543-552, DOI: 10.24263/2304-974X-2017-6-3-14

10. Shin D. M., Lee J. S., Jung H. W., Hyun J. C. (2007), Multiplicity, bifurcation, stability and hysteresis in dynamic solutions of film blowing process, Journal of Rheology, 51(4), pp. 605-621, DOI: $10.1122 / 1.2736405$

11. Kashyap M. J., Ghosh A. K. (2013), Processing, rheology and characterization of polypropylene nanocomposites and their blown films, Journal of Plastic Film and Sheeting, 29(3), pp. 228-248, doi: 10.1177/8756087912473099

12. Khonakdar H. A., Morshedian J., Nodehi A. O. (2002), Mathematical and Computational Modeling of Heat Transfer and Deformation in Film Blowing Process, Journal of Applied Polymer Science, 86(9), pp. 2115-2123, DOI: 10.1002/app.10769

13. Hong Y., Coombs S. J., Cooper-White J. J., Mackay M. E., Hawker C.J., Malmström E., Rehnberg N. (2000), Film blowing of linear low-density polyethylene blended with a novel hyperbranched polymer processing aid, Polymer, 41(21), pp.7705-7713. DOI: 10.1016/S0032-3861(00)00130-0

14. Wang W., Zhang H., Jia R., Dai Y., Dong H., Hou H., Guo Q. (2017), High performance extrusion blown starch/polyvinyl alcohol/clay nanocomposite films, Food Hydrocolloids, 79, pp. 534-543, DOI: 10.1016/j.foodhyd.2017.12.013

15. Thunwall M., Kuthanová V., Boldizar A., Rigdahl M. (2008), Film blowing of thermoplastic starch, Carbohydrate Polymers, 71(4), pp. 583-590, DOI: 10.1016/j.carbpol.2007.07.001

16. Zullo R., Iannace S. The effects of different starch sources and plasticizers on film blowing of thermoplastic starch: Correlation among process, elongational properties and macromolecular structure, Carbohydrate Polymers, 77(2), pp. 376-383, DOI: 10.1016/j.carbpol.2009.01.007

17. La Mantia F. P., Ceraulo M., Mistretta M. C., Morreale M. (2018), Rheological Behaviour, Mechanical Properties and Processability of Biodegradable Polymer Systems for Film Blowing, Journal of Polymers and the Environment, 26(2), pp. 749-755, DOI: 10.1007/s10924-017-0995-4

18. Mallegni N., Phuong T. V., Coltelli M.-B., Cinelli P., Lazzeri A. (2018), Poly(lactic acid) (PLA) Based Tear Resistant and Biodegradable Flexible Films by Blown Film Extrusion, Materials, 11(1), pp. 148-163, DOI:10.3390/ma11010148

19. Singh S., Gupta R. K., Ghosh A. K., Maiti S. N., Bhattacharya S. N. (2010), Poly (L-lactic acid)/layered Silicate Nanocomposite Blown Film for Packaging Application: Thermal, Mechanical and Barrier Properties, Journal of Polymer Engineering, 30(5-7), pp. 361-376, DOI:10.1515/POLYENG.2010.30.5-7.361

20. Zhang X.M., Elkoun S., Ajji A., Huneault M.A. (2003), Oriented structure and anisotropy properties of polymer blown films: HDPE, LLDPE and LDPE, Polymer, 45(1), pp. 217229, DOI: $10.1016 /$ j.polymer.2003.10.057 
21. Micic P., Bhattacharya S. N. (2000), Rheology of LLDPE, LDPE and LLDPE/LDPE blends and its relevance to the film blowing process, Polymer International, 49(12), pp. 15801589, DOI: 10.1002/1097-0126(200012)49:12<1580::AID-PI547>3.0.CO;2-Q

22. Münstedt H., Kurzbeck S., Stange J. (2006), Importance of elongational properties of polymer melts for film blowing and thermoforming, Polymer Engineering and Science, 46(9), pp. 1190-1195, DOI: 10.1002/pen.20588

23. Kolarik R., Zatloukal M. (2013), Evaluation of Variational Principle Based Model for LDPE Large Scale Film Blowing Process, AIP Conf. Proc., 1526, pp. 119-127, DOI: $10.1063 / 1.4802607$

24. Lamnawar K., Maazouz A., Cabrera G., Al-Itry R. (2018), Interfacial Tension Properties in Biopolymer Blends: From Deformed Drop Retraction Method (DDRM) to Shear and Elongation Rheology-Application to Blown Film Extrusion, International Polymer Processing, 33(3), pp. 411-424, DOI: 10.3139/217.3614

25. Mallet, B., Lamnawar, K., Maazouz, A. (2014), Improvement of Blown Film Extrusion of Poly(lactic acid): Structure-Processing- Properties Relationships, Polymer Engineering and Science, 54(4), pp. 840-857, DOI: 10.1002/pen.23610

26. Lee J. S., Jung H. W., Hyun J. C. (2011), Transient solutions of nonlinear dynamics in film blowing process accompanied by on-line crystallization, Journal of Rheology, 55(2), pp. 257-271, DOI: 10.1122/1.3532091

27. Muslet I. A., Kamal R. (2004), Computer simulation of the film blowing process incorporating crystallization and viscoelasticity, Journal of Rheology, 48(3), pp. 525-550, DOI: $10.1122 / 1.1718500$

28. Oliviero M., Di Maio E., Iannace S. (2010), Effect of molecular structure on film blowing ability of thermoplastic zein, Journal of Applied Polymer Science, 115(1). pp. 277-287, DOI: 10.1002/app.31116

29. Mikulionok I.O. (2012), Modeling of the Heat Processing of Continuously Molded Product, Russian Journal of Applied Chemistry, 85(9), pp. 1482-1492, DOI: $10.1134 / \mathrm{S} 1070427212090285$

30. Mikulionok I., Gavva O., Karvatskii A., Yakymchuk M. (2017), Modeling and analysis of the process of polymeric film cooling on the drum with a liquid cooling agent, EasternEuropean Journal of Enterprise Technologies, 5/5(89), pp. 67-74, DOI: 10.15587/17294061.2017.110687

31. Mikulionok I.O., Radchenko L.B. (2011), Simulation of Liquid Cooling of an Extruded Sleeve Plastic Film, Russian Journal of Applied Chemistry, 85(6), pp. 1080-1084, DOI: 10.1134/S1070427211060334

32. Petrenko V., Pryadko M.,Zasyadko Ya., Miroshnyk M. (2016), Modeling of heat transfer in free down flowing laminar liquid films with development wavy structure at the regime of evaporation from the interface, Ukrainian Food Journal, 5(1), pp. 162-173.

33. Wong H. Y. (1977), Handbook of Essential Formulae and Data on Heat Transfer for Engineers, Longman Group, Ltd., London.

34. Gapon V.S. (1982), Issledovanie protsessa proizvodstva plyonok iz termoplastov s zhidkostnym okhlazhdeniem, Research of production process of films of thermoplastics with liquid cooling, Thesis of Candidate of Technical Sciences, Kyiv (in Russian). 


\title{
Impact of nanosized aluminum hydroxide on the structural and mechanical properties of sugar beet tissue
}

\author{
Taras Nykytiuk ${ }^{1}$, Valentyn Olishevskiy ${ }^{1}$, \\ Evhen Babko ${ }^{1}$, Oleg Prokopiuk ${ }^{2}$
}

1 - National University of Food Technologies, Kyiv, Ukraine

2 - LLC "Teplocom"

Keywords:

Sugar beet

Shavings

Extraction

Nanosize

Aluminum

hydroxide,

Elasticity

\section{Article history:}

Received

05.05.2018

Received in

revised form

21.09.2018

Accepted

28.09.2018

Corresponding

author:

Taras Nykytiuk

E-mail:

tarasnykytiuk@

gmail.com
DOI:

$10.24263 / 2304-$

974X-2018-7-3-13

\section{Abstract}

Introduction. The study was conducted to confirm the feasibility of using aluminum hydroxide in the process of extracting sucrose from sugar beet shavings to increase the structural and mechanical properties of beet tissues.

Materials and methods. Investigation of the influence of aqueous solutions of additional reagents on the structural and mechanical properties of beet tissue by the method of hydraulic pressing of samples of sugar beet tissue of cylindrical shape from a geometric dimensional specification. Before that, each of the samples obtained was subjected to heat treatment in aqueous solutions of various reagents at a temperature of $70-72{ }^{\circ} \mathrm{C}$ with an experiment duration of 60 minutes.

Results and discussion. Processing of samples of beet tissue with additional solutions of aluminum sulfate, calcium sulfate, aluminum hydroxide and combinations thereof during extraction at a temperature of $70-72{ }^{\circ} \mathrm{C}$ will reduce the degree of deformation of samples of beet tissue compared to a sample that has not been treated with additional reagents. The degree of a beet tissue sample treated with a solution of nanosized aluminum hydroxide is $18 \%$ lower than the control sample without processing with additional reagents. This result can be explained by the high chemical activity of the aluminum hydroxide reagent. The ions of this compound are capable of forming in the surface layer of tissue fairly stable, insoluble complex compounds with pectin and protein substances, which, adsorbing on a layer of beet tissue, form something similar to the molecular framework, which increases the stability of beet tissue to compressive loads.

The quantity that can accurately describe the quality of beet tissue, its ability to restore its shape and elasticity during periodic compressive loads, is precisely the elastic modulus. During the heat treatment at a temperature of $70-72{ }^{\circ} \mathrm{C}$ the elastic modulus of samples of beet tissues, which was subjected to treatment with additional reagents, is $35-40 \%$ higher than a sample of beet tissue without processing with additional reagents.

Conclusions. Application in the process of extraction of nanosized aluminum hydroxide, will ensure the integrity of the structure of beet tissues in the processes of extraction and compression; ensures the high quality of extractant, diffusion and purified juice. 


\section{Introduction}

The speed and quality of the flow mass exchange processes in the extraction of sucrose from sugar beet shavings most significantly affect the structural and mechanical properties of beet tissue, such as its strength, elasticity and resilience. The traditional diffusion and press method for extracting sucrose from sugar beet shavings with the return of pulp-pressed water for extraction does not always provide the necessary degree of its extraction. The maximal effective extraction of sucrose from sugar beet shavings can be achieved in such a mode of the whole process, when beet tissue have optimal parameters of elasticity and durability. In view of this, today the issues of improving the structural and mechanical properties of sugar beet shavings, namely, the preservation of the integrity of the structure of its tissue in the process of juice extraction are relevant [1-6].

\section{Analysis of scientific research}

One of the modern directions of increasing the structural and mechanical characteristics of beet tissues is the use of chemical reagents in the process of extraction [7, $8,9]$. It is known that ions of polyvalent metals $\left(\mathrm{Ca}^{2+}, \mathrm{Fe}^{2+}, \mathrm{Fe}^{3+}, \mathrm{Al}^{3+}\right.$ etc. $)$ are able to bind polysaccharides of the cell walls of sugar beet shavings into insoluble complexes, thereby reducing the transition of non-sugars in diffusion juice. Therefore, the use of additional reagents will increase the elastic modulus of sugar beet shavings and, as a result, increase its transport and pressing characteristics.

In today's time, technology has become quite widespread with the use of minced natural gypsum - a sulfate-grade mineral or a slightly dissolved $\mathrm{CaSO}_{4}-\mathrm{Ca}\left(\mathrm{HSO}_{4}\right)_{2}$ salt obtained from a sugar plant through oxidation of factory lime milk with sulfur dioxide or sulfuric acid in the process of extraction $[10,11]$. But, the given method has a number of problems in application and does not give the desired result, namely - increase of structural and mechanical properties of beet shavings, on which directly the quality parameters of the intermediate products of sugar beet production are directly dependent.

Also, one of the directions of strengthening the beet shaving tissue in the traditional diffusion and press method of extracting sucrose from beet shavings, which has been developing intensively over the last decades, is the chemical effect on beet shavings by appropriate preparation of feed water for the extraction process $[12,13,14]$.

The use of additional reagents in the extraction process is essential for the intensification of the sugar beet pulp pressing process by improving its structural and mechanical properties. This problem in our time is extremely relevant due to the increase in prices for fuel materials, which negatively affects the technical and economic indicators of sugar beet pulp drying.

\section{Materials and methods}

The maximum effective production of sucrose from beet shavings can be achieved with a diffusion process in which the beetroot tissue has optimal strength and elasticity.

\section{Experimental installation}

Investigation of the influence of aqueous solutions of additional reagents on the structural and mechanical properties of beet tissues was carried out on a laboratory installation, presented in Figure 1. 


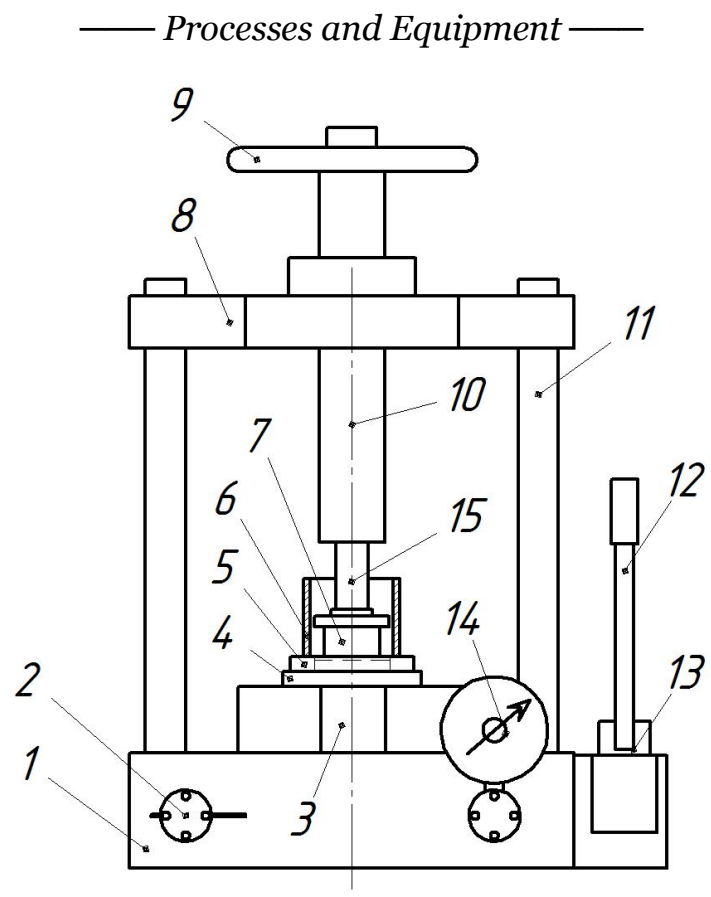

Figure 1. Scheme of an adapted laboratory installation for the study of structural and mechanical characteristics of sugar beet tissue:

1 - housing; 2 - final screw; 3 - tank; 4 - "heel"; 5 - perforated bottom; 6 - removable compression chamber; 7 - prototype; 8 - crossbeam; 9 - screw handle; 10 - clamping screw; 11 - rack;

12 - handle of the pump; 13 - hand pump; 14 - manometer; 15 - hydraulic cylinder.

The principle of hydraulic pressing is based on the installation. The laboratory press (Figure 1) consists of a housing 1, vertical racks 11, to which the crossbeam 8 is attached. On "the heel" 4 is placed a removable compression chamber 6 with a perforated bottom 5. Rotation of the handle of the screw 9 presses the prototype to the pressure screw 10. using the pump handle 12 pumps oil into the hydraulic cylinder 15 and vertically lifts "the heel" 4. Pressure is controlled by a manometer 14 .

The use of this engineering compression equipment provided a high pressure of compaction of the test material to a state with a small (close to zero) volume content of the gas-liquid phase [9].

During pressing, depending on the structural changes taking place in the sample of a disperse material of a given volume, 4 press zones can be conventionally identified (Figure 2).

At the 1st stage of pressing, the dispersion medium (air, water) is displaced from the volume of the material; the process is characterized by a slight increase in pressure with significant movements of the poisson.

At the second stage, the dispersion of the directly dispersed phase takes place; the process is characterized by a reduction in the displacement of the poisson and a gradual increase in pressure. 
At the third stage, the gas-liquid phase is displaced from the volume of solid particles of the material; the process is characterized by a significant increase in pressure with small displacements.

At the fourth stage, the components of the dispersed phase (cell destruction) are condensed with a sudden increase in pressure and an insignificant amount of displacement of the poisson.

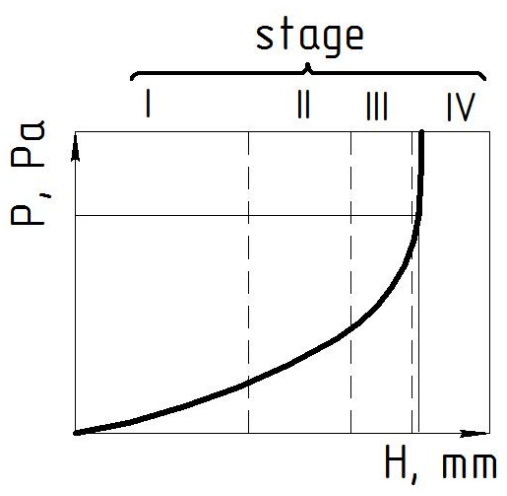

Figure 2. Graph of pressure dependence $P$ on linear deformation $H$ when pressing a disperse test sample

\section{Method}

Investigation of the structural and mechanical characteristics of sugar beet tissue was carried out as follows: from the root of sugar beet, samples of cylindrical shape with a diameter of $d 50 \mathrm{~mm}$ and a thickness (height $h$ ) of $25 \mathrm{~mm}$ were obtained. Each of the samples obtained was subjected to heat treatment in aqueous solutions of various reagents at a temperature of $70-72{ }^{\circ} \mathrm{C}$ with an experiment duration of 60 minutes $[15,21]$.

\section{Materials}

As reagents, solutions of $\mathrm{CaSO}_{4}, \mathrm{Al}_{2}\left(\mathrm{SO}_{4}\right)_{3}$ and nanosized aluminum hydroxide $\mathrm{Al}(\mathrm{OH})_{3}$ (Fig. 3), obtained by the method of underwater electrospark synthesis [Patent $38461 \mathrm{UA}]$ and a combination of aqueous solutions of these reagents were used. Ratio, reagent concentrations and laboratory results of qualitative indices of diffusion juice are described in Table 1.

\section{Order of research}

After the end of the extraction process, the prototypes were placed in the chamber 6 of the laboratory installation and pressings were carried out in the effort range of $0.5-2.5 \mathrm{MPa}$. At the same time, structural changes and geometric shapes of beet tissue samples, namely, the height $h$, before and after the compressive loads, were measured. The results were compared with control samples of partially desiccated beetroot tissue [16, 17]. 


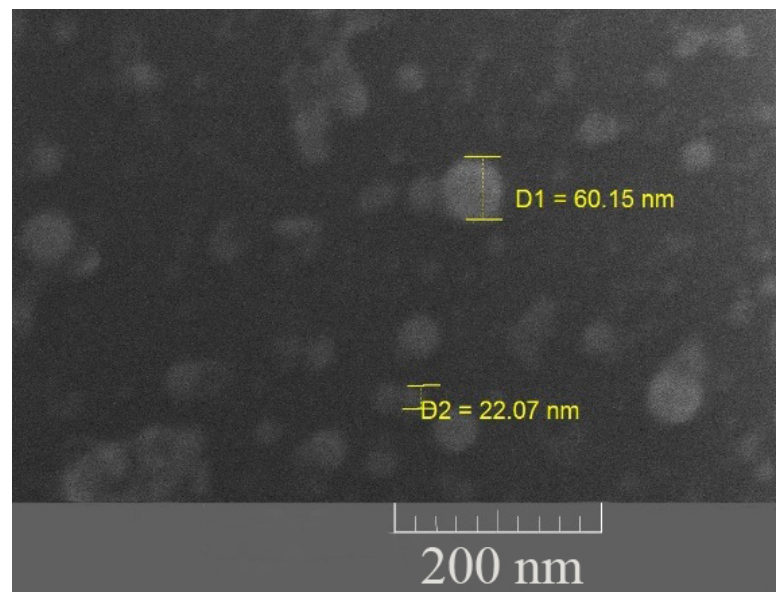

Figure 3. Electron microscopic image of nanosized aluminum hydroxide $\mathrm{Al}(\mathrm{OH})_{3}$

\section{Processing of research results}

The main criterion for determining the degree of quality of beet tissue is its ability to restore its shape and elasticity under periodic compressive loads during extraction and subsequent pressing in production conditions. The magnitude, exactly can describe the quality of the beet tissue, is precisely the elastic modulus [16-20].

The elastic modulus was determined according to Hooke's law with respect to:

$$
E=\frac{G}{\varepsilon}
$$

where: $G$ - the tension caused in the sample by the acting force; $\varepsilon$ - the elastic deformation of the sample caused by stress.

$$
G=\frac{P}{F}
$$

where: $P$ - the compression force applied to the sample; $F$ - the cross-sectional area of the sample.

$$
\varepsilon=\frac{\Delta h}{h}
$$

where: $\Delta h$ - change in the size of the sample after deformation; $h$ - the initial size of the sample to the action of the force.

\section{Results and discussion}

The results of the study of the influence of nanosized $\mathrm{Al}(\mathrm{OH})_{3}$ aluminum hydroxide on the structural and mechanical characteristics of beet pulp are shown in Figure 4 and in Table 1. 
Table 1

Impact of aqueous solutions of additional reagents on qualitative indices of diffusion juice and on structural and mechanical characteristics of beet tissue

\begin{tabular}{|c|c|c|c|c|c|c|c|c|c|c|}
\hline \multirow{2}{*}{ 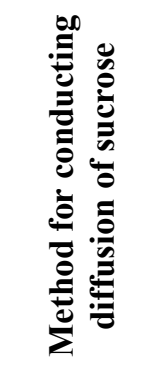 } & \multicolumn{2}{|c|}{ Concentrations } & \multicolumn{3}{|c|}{ Diffusion juice } & \multirow{2}{*}{ 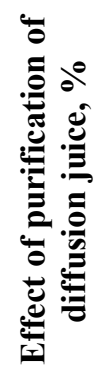 } & \multirow{2}{*}{ 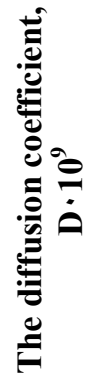 } & \multicolumn{2}{|c|}{ E, MPa } & \multirow{2}{*}{ 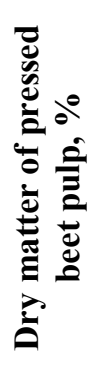 } \\
\hline & C1 & C2 & 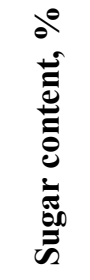 & 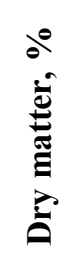 & 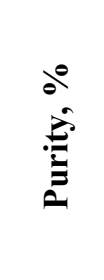 & & & E1 & E2 & \\
\hline Typ & & & 3 & 16,9 & 53 & 15,04 & 0,048 & 6,1 & 95 & 23,5 \\
\hline $\mathbf{A l}_{2}\left(\mathbf{S O}_{4}\right)$ & 10 & & & 17,3 & 92,01 & 29,3 & 0,077 & & & 24,2 \\
\hline $\mathrm{CaSO}_{4}$ & 10,0 & & & 16,9 & 91,2 & 21,45 & 0,057 & 6 , & & 25,8 \\
\hline $\mathrm{Al}(\mathrm{OH})_{3}$ & 0 , & & 15 & 16,6 & 92 & 37,8 & 0,130 & 6 & 1 & 27,0 \\
\hline $\begin{array}{l}\mathrm{Al}_{2}\left(\mathbf{S O}_{4}\right)_{3} / \\
\mathrm{CaSO}_{4}\end{array}$ & $\begin{array}{l}10, \\
10,\end{array}$ & & 15 & 17,0 & 8 & 02 & 6 & 6,1 & 1,31 & 26 \\
\hline $\begin{array}{l}\mathbf{A l}_{2}\left(\mathbf{S O}_{4}\right)_{3} / \\
\mathrm{CaSO})_{4} / \\
\mathrm{Al}(\mathbf{O H})_{3}\end{array}$ & $\begin{array}{c}10,0 / \\
10,0 / \\
0,2 \\
\end{array}$ & $\begin{array}{r}0,0 \\
0,0 \\
0,00\end{array}$ & 15,9 & 17,1 & 93,0 & 38,73 & 0,110 & 6,1 & 1,35 & 27,3 \\
\hline $\begin{array}{l}\mathrm{Al}_{2}\left(\mathrm{SO}_{4}\right)_{3} / \\
\mathrm{Al}(\mathrm{OH})_{3}\end{array}$ & $\begin{array}{c}10,0 / \\
0,2 \\
\end{array}$ & $0,02 /$ & 16,07 & 17,3 & 92,9 & 37,8 & 0,101 & 6,1 & 1,28 & 27,2 \\
\hline $\begin{array}{l}\mathrm{CaSO}_{4} / \\
\mathrm{Al}(\mathrm{OH})_{3}\end{array}$ & $\begin{array}{c}10,0 / \\
0,2 \\
\end{array}$ & $\begin{array}{c}0,04 / \\
0,0015\end{array}$ & 15,6 & 16,9 & 91,8 & 27,3 & 086 & 6,1 & 1,22 & 26,8 \\
\hline
\end{tabular}

where: $\mathrm{C}_{1}-$ Concentrations of reagents in solution, $\%$;

$\mathrm{C}_{2}-$ Concentrations of reagents to the mass of beet shavings, \%;

$\mathrm{E}$ - elastic modulus of sugar beet tissue;

$\mathrm{E}_{1}$ - before extraction;

$\mathrm{E}_{2}-$ after extraction.

\section{Effect of nanosized aluminum hydroxide on the degree of deformation of sugar beet tissue}

Analyzing the diagram of deformation changes (Figure 3), it can be said that the processing of beet tissue samples with additional solutions of $\mathrm{Al}_{2}\left(\mathrm{SO}_{4}\right)_{2}, \mathrm{CaSO}_{4}, \mathrm{Al}(\mathrm{OH})_{3}$ and their combinations during extraction at a temperature of $70-72{ }^{\circ} \mathrm{C}$ will reduce the degree of deformation of the samples beet tissue compared with a sample that has not been treated with additional reagents. In addition, it should be especially noted that the degree of the beet tissue sample that was treated with $\mathrm{Al}(\mathrm{OH})_{3}$ solution is $18 \%$ lower than the control sample without treatment with additional reagents (Figure 5). Such an increased stability of beet tissue samples, as well as its rigidity and the ability to resist deformation under the action of force, can be explained by the high chemical activity of the $\mathrm{Al}(\mathrm{OH})_{3}$ reagent $[15$, 21]. The ions of this compound are capable of forming in the surface layer of the tissue sufficiently stable insoluble complex compounds with pectin and protein substances, which, adsorbed on a layer of beet tissue, form something like a molecular framework that 
increases the stability of beet tissue to compressive loads. Describing Figure 5 , it is worth mentioning that in sample $5 c$, there is a part of non-deformable cellular structures of beet tissue in a much larger amount than in sample $5 b$, which indicates an increase in the stability of beetroot tissue treated with $\mathrm{Al}(\mathrm{OH})_{3}$ solution and approximation of its elastic characteristics to the tissue sample fresh sugar beet $5 a$.

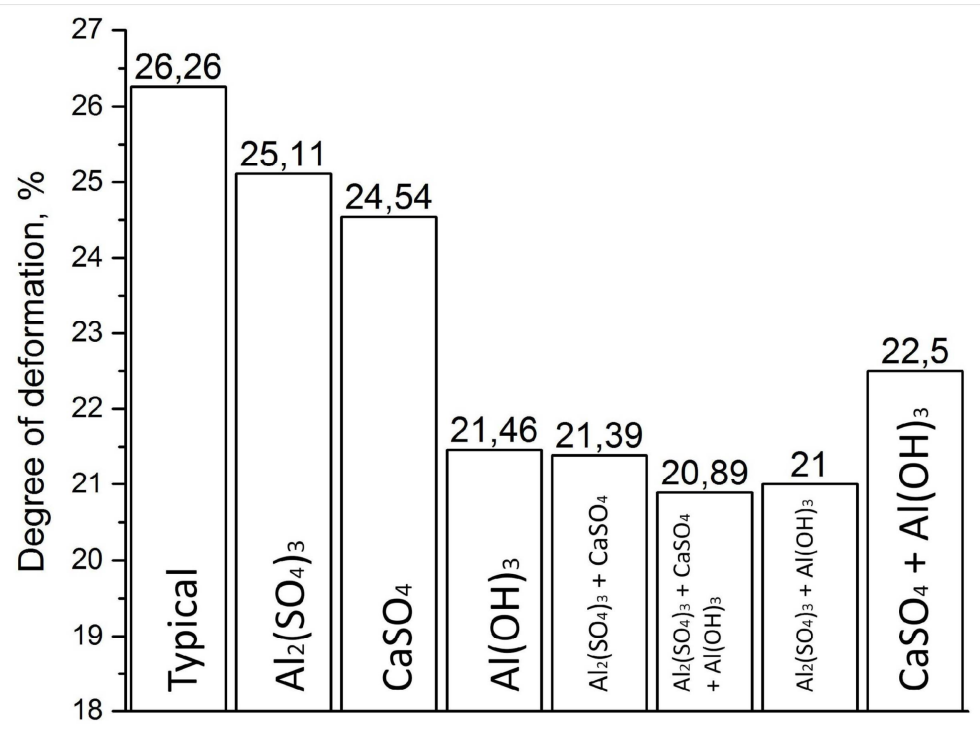

Reagents for the treatment of sugar beet tissue

Figure 4. Indicators of deformation changes in samples of beet tissue using different reagents in the sucrose extraction process at a temperature of $70-72^{\circ} \mathrm{C}$

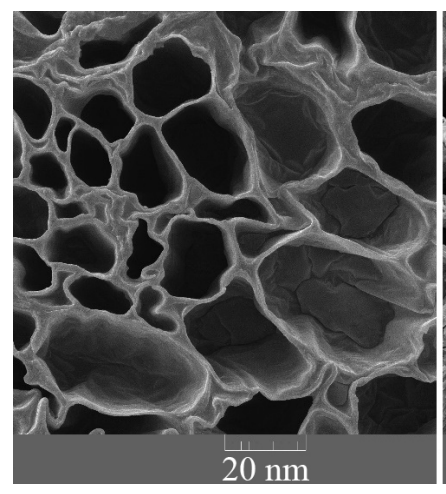

$a$

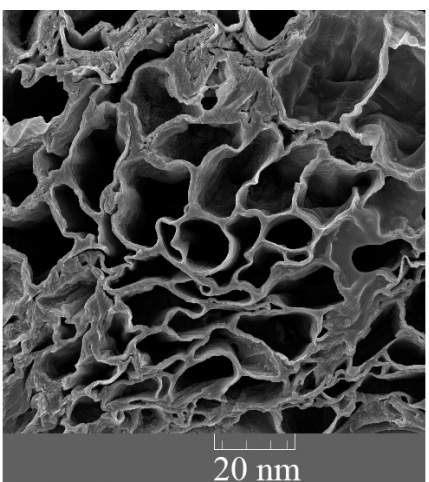

b

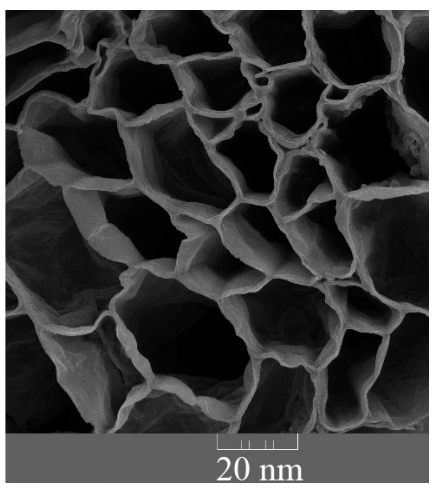

c

Figure 5. Electron microscopic image of sugar beet tissue samples after compressive loads: a - tissue of fresh sugar beet;

b - sample of sugar beet tissue without finishing with additional reagents in the extraction process;

c - sample of sugar beet tissue with the addition of reagents, which included $\mathrm{Al}(\mathrm{OH})_{3}$ during the extraction. 


\section{Effect of nanosized aluminum hydroxide on the elastic modulus of sugar beet tissue}

The next stage of the work was study the effect of the use of additional reagent solutions in the extraction process on the elastic modulus of sugar beet tissue.

Sugar beet tissue has the ability to partially restore its elasticity when it is watersaturated and at a temperature that causes its thermal denaturation $[15,21]$. It is obvious that during the extraction process in batch production plants, the beet shavings absorb moisture and under high temperatures are destroyed. As the temperature of the process increases, high-molecular compounds from less stable tissues pass into solution, the geometry of the sugar beet shavings changes, the hydrodynamic conditions in the diffusion apparatus deteriorate, the permeability of the co-extrusion mixture and, consequently, the purity of the diffusion juice deteriorates [15, 21, 22, 23].

The size of the elastic modulus depends on the turgor of the tissue, which, in turn, depends on the directivity of the functioning of the cell membranes, so the factors that negatively affect the turgor also reduce the elastic modulus. So, for healthy sugar beets, the elastic modulus ranges from 6 to $14 \mathrm{MPa}$.

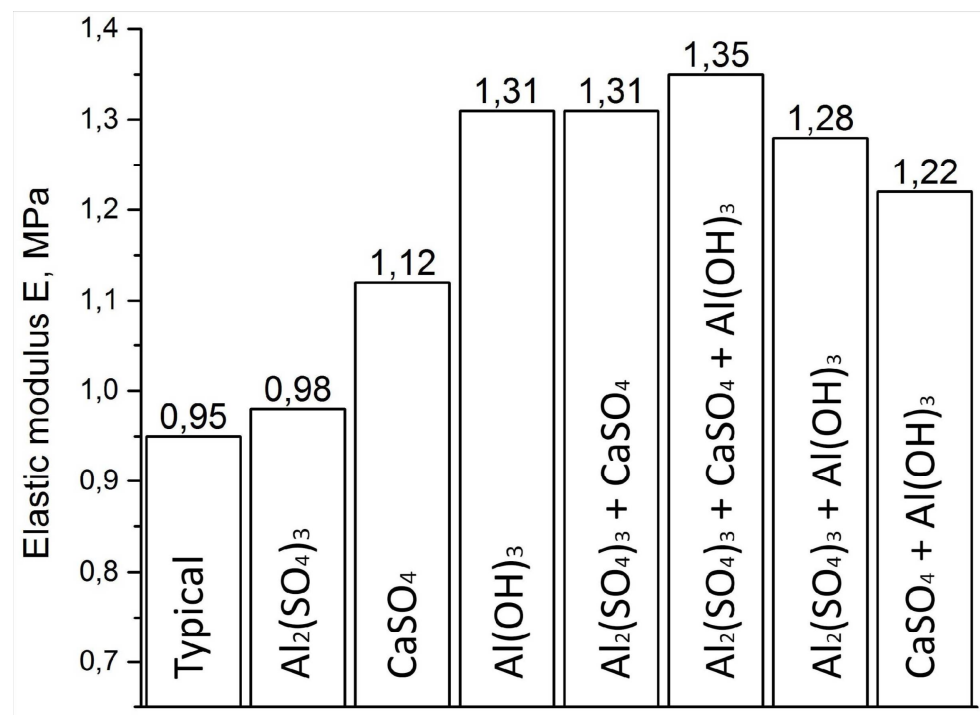

Reagents for the treatment of sugar beet tissue

Figure 6. Indicators of the elastic modulus of sugar beet tissue samples when using various reagents in the extraction of sucrose at a temperature of $70-72{ }^{\circ} \mathrm{C}$.

The results of the studies presented in Table 1 were obtained by statistical processing of data from a series of experiments $[15,21]$. The accuracy of the measurement results and calculations of the elastic modulus is within 3\%, which indicates a fairly high accuracy and reliability of the research results. The advantages of this modified and adapted method for the determination of structural and mechanical characteristics should also include the not 
very high complexity of carrying out measurements and calculations, which will allow the fastest control of the elastic characteristics of beet tissue under production conditions.

From the graph of the values of the elastic modulus shown in Figure 6, it follows that during the heat treatment at a temperature of $70-72{ }^{\circ} \mathrm{C}$ the elastic modulus of beet samples was treated with additional reagents by $35-40 \%$ higher than a sample of beet tissue without finishing with additional reagents. This qualitative difference will ensure the stability of the beet shavings to the external factors and will provide the necessary elasticity in the processes of extraction and subsequent compression under production conditions.

\section{Effect of nanosized aluminum hydroxide on the moisture retention capacity of sugar beet tissue}

Based on the results shown in Figure 7, it can be said that, with the same degree of pressing of the beet shavings, more moisture is removed when the additional reagent $\mathrm{Al}(\mathrm{OH})_{3}$ is used in the extraction process. Therefore, it can be argued that the use of an additional reagent $\mathrm{Al}(\mathrm{OH})_{3}$ alone or in combination with other reagents in the process of extraction of sucrose from beet shavings allows to achieve a high degree of dehydration of beet pulp that reduces the energy costs for the processes is about further pressing and drying. In addition, such results of water retention capacity indicate that the use of $\mathrm{Al}(\mathrm{OH})_{3}$ additional reagent in the process of extraction will increase the quantity and quality of pulppress water, guarantees the production of a reduction in economic costs and improvement of the ecological situation around the sugar plant.

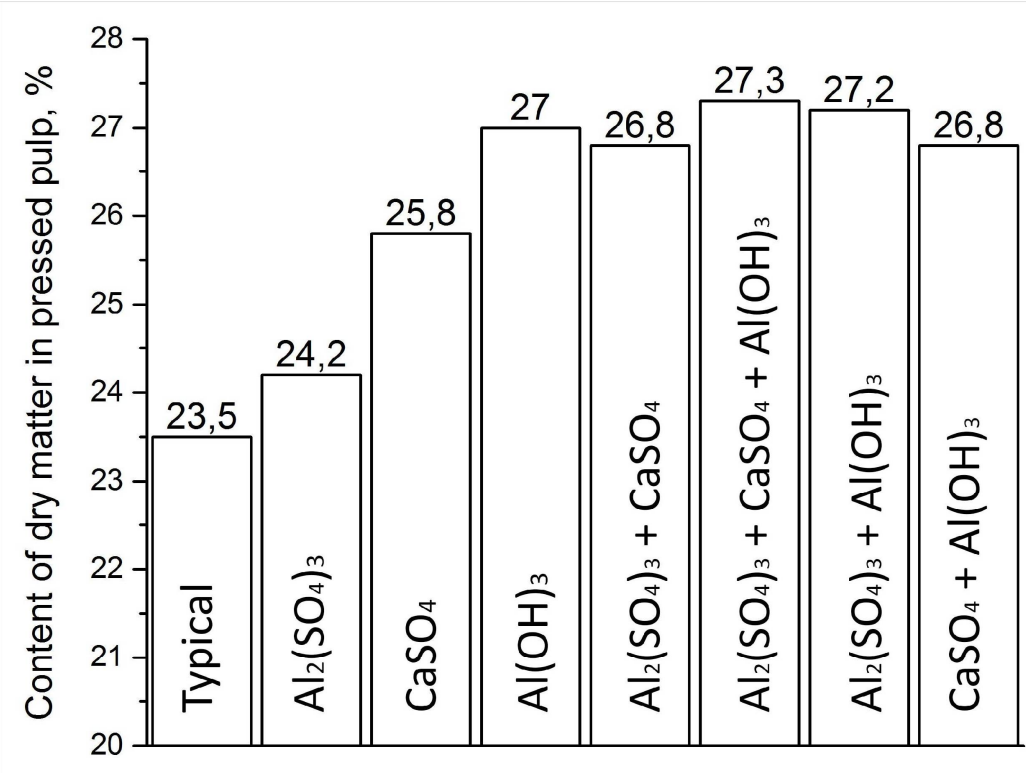

Reagents for the treatment of sugar beet tissue

Figure 7. The content of dry substances in samples of sugar beet tissue with the same degree of pressing when using different reagents in the extraction of sucrose at a temperature of $70-72{ }^{\circ} \mathrm{C}$ 


\section{Conclusions}

1. All additional reagents improve the elastic characteristics of the beet tissue, while the nano-sized aluminum hydroxide $\mathrm{Al}(\mathrm{OH})_{3}$ alone or in combination with other reagents showed that it is its presence in the solution of the additional reagent that guarantees the best structural and mechanical properties of the sugar beet tissue.

2. Application in the process of extraction of nanosized aluminum hydroxide $\mathrm{Al}(\mathrm{OH})_{3}$, obtained by the method of underwater electrospark synthesis, will ensure the integrity of the structure of sugar beet tissue in the processes of industrial extraction and pressing; guarantees high quality of extractant, diffusion and purified juice.

3. The nanosized aluminum hydroxide $\mathrm{Al}(\mathrm{OH})_{3}$, in comparison with conventional reagents, is economically and technologically promising for use in the extraction and pressing of sugar beetroot shavings. The use of the proposed method for determining the elastic modulus of a sugar beet sample will allow accurately and promptly control the structural and mechanical characteristics of the raw material during its storage and processing, which allows optimizing the process of extraction of sucrose and compression of the pulp and, thus, improving the yield and quality of the target product.

\section{References}

1. Asadi M. (2007), Beet Sugar Handbook, John Wiley and Sons, Hoboken, New Jersey, pp. 162 163, pp. 435-450.

2. Bogdanovic, Branislav V., Seres, Zita I., Gyura, Julianna F. (2013), The influence of extraction parameters on the quality of dried sugar beet pulp, Hemijska industrija, 67(2), pp. 269-275

3. Ermanno Prati, Franco Maniscalco (2013), How to improve the performance of pulp pressing? Sugar industry-zuckerindustrie, 138(3), pp. 171-174.

4. Ermanno Prati, Franco Maniscalco (2013), Recommendations on how to increase the sugar beet pulp press efficiency, International sugar journal, 115(1373), pp. 339-343.

5. Ermanno Prati (2015), The role and the influence of fine pulp in sugar beet processing, Sugar industry-zuckerindustrie, 140(6), June, pp. 370-374.

6. Ermanno Prati (2016), Impact of fine pulp during sugar beet processing, International sugar journal, 118 (1406), pp. 118-121.

7. Tovar Jose Carlos et al. (2015), Plant Pectin Methylesterase Treatments Dramatically Reduce Water-binding in Sugar Beet Pulp via Calcium Crosslinking, Arkansas State University, Arkansas.

8. Bosse E.D. (1997), Increase in dry substance of pressed pulp by addition of pressing aids into the pulp press, 29th General Meeting of the American Society of Sugar Beet Technologists Phoenix, Arizona March 2 to 5, pp. 233-235.

9. Ueli Wyss, Catherine Metthez, Yves Arrigo, (2015), Silage quality: pressed sugar-beet pulp with added molasses, Agrarforschung schweiz, 6(9), pp. 416-423.

10. Osadchy L. (2013), Use of gypsum in the diffuse process of sugar beet production, Journal of Sugarcorns of Ukraine, 6(85), pp. 13-17.

11. Costa Crusciol, C. A., Foltran, R., Rossato, O. B., et al. (2014) Effects of surface application of calcium-magnesium silicate and gypsum on soil fertility and sugarcane yield, Revista Brasileira De Ciencia Do Solo, 38(6), pp. 1843-1854.

12. Gul S., Ahmed A. El Gohary Harasek, M. (2012), Beet sugar pulp-press water treatment: A comparison of nanofiltration and reverse osmosis processes, Euromembrane Conference, London, England, September 23-27, Procedia Engineering, 44, pp. 634-634. 
13. Mareike Monninger (2017), Measuring water content of pressed beet pulp - microwave transmission measurement for process optimization and quality improvement, Sugar industryzuckerindustrie, 142(11), November, pp. 648-650.

14. Yapo B.M., Robert C., Etienne I., Wathelet B., Paquot M. (2007), Effect of extraction conditions on the yield, purity and surface properties of sugar beet pulp pectin extracts, Food Chemistry, 100(4), pp. 1356-1364.

15. Ukrainets A., Olishhevskyi V., Pushancko N., Babko E., Nykytiuk T. (2016), Development of resource-saving process of extraction of sucrose from sugar beet using aluminum nanocomposite, Improvement of processes and equipment - a pledge of innovative development of the food industry, materials of the interface. science-practice Conf., 8-10 November, Kyiv, NUFT, pp. 117-119.

16. Chee Kiong Siew, Peter A. Williams (2008), Role of Protein and Ferulic Acid in the Emulsification Properties of Sugar Beet Pectin, Centre for Water-Soluble Polymers, North East Wales Institute, Plas Coch, Mold Road, Wrexham LL11 2AW, United Kingdom, J. Agric. Food Chem., 56(11), pp. 4164-4171.

17. Xin Huanga, Dong Li, Li-jun Wanga (2017), Characterization of pectin extracted from sugar beet pulp under different drying conditions, Journal of Food Engineering, 211, October, pp. 16.

18. Belyaeva L., Chugguaunov A., Ozerov D., Anateeva P. (2007) Investigation of the elasticity of sugar beet tissue, Sugar, 5, pp. 22-24.

19. Xin Huanga, Dong Li, Li-jun Wanga (2017), Effect of Drying Methods on the Rheological Properties of Sugar Beet Pulp Pectin, International Journal of food engineering, 13(4), № 20160165.

20. Xin Huanga, Dong Li, Li-jun Wanga (2018), Effect of particle size of sugar beet pulp on the extraction and property of pectin, Journal of food engineering, 218, pp. 44-49.

21. Olishhevskyi V., Ukrainets A., Lopatko K., Pushancko N., Babko E., Vilchenko A., Kostiuchenko V., Marynin A., Nykytiuk T., Lapshin S., (2016), Experience of using nanocomposite of aluminum in beet-sugar production, Sugar of Ukraine, 11-12(131-132), pp. $11-17$.

22. Xiaobing Guo, Xiaoming Guo, Shujuan Yu (2018), Influences of the different chemical components of sugar beet pectin on the emulsifying performance of conjugates formed between sugar beet pectin and whey protein isolate, Food Hydrocolloids, 82, pp. 1-10.

23. Guanhua Li, Yanxin Sun, Wenjing Guo (2018), Comparison of various pretreatment strategies and their effect on chemistry and structure of sugar beet pulp, Journal of cleaner production, 181, pp. 217-223. 


\title{
Torsional oscillations of an auger multifunctional conveyor's screw working body with consideration of the dynamics of a processed medium continuous flow
}

\author{
Oleg Lyashuk ${ }^{1}$, Maria Sokil ${ }^{2}$, Yuriy Vovk ${ }^{1}$, Anna Tson ${ }^{1}$, \\ Andrii Gupka1, Oleksandr Marunych ${ }^{1}$ \\ 1 - Ternopil Ivan Pul'uj National Technical University, Ternopil, Ukraine \\ 2 - Lviv Polytechnic National University, Lviv, Ukraine
}

Keywords:

Screw

Amplitude

Resonance

Conveyor

\section{Article history:}

Received

02.05.2018

Received in revised form

25.09.2018

Accepted

28.09.2018

Corresponding

author:

Yuriy Vovk

E-mail:

vovkyuriy@

ukr.net

DOI:

$10.24263 / 2304-$

974X-2018-7-3-14

\section{Abstract}

Introduction. The aim of the article is a mathematical model of vibrations of working part of screw conveyer for transporting friable loads taking into account the changes of closeness of the processed environment, speed of circulation of screw, weight while appearing of the phenomenon of resonance.

Materials and methods. It is recesrced the turning vibrations of spiral working part of screw multifunctional conveyer, which appeare as a result of action of processing environment. The recerch was carried out by mathematical modelling method.

Results and discussions. The limiting factors which complicate a design are the unevenness of the division of environment along the length of screw; a body makes flexible vibrations; the motion of the processed environment along the working screw causes the small vibrations of bend, causes appearance of "additional forces". For providing the authenticity of mathematical model ti has been introduced the next suppositions: the working part of screw is turned with the permanent angle speed around its longitudinal which in the undeformed position coincides coincides with an axis OX; the transversal transferring of neutral axis of working screw at the arbitrary moment in perpendicular direction of its undeformed position is determined by the vector (in relation to the fixed frame of reference of OXYZ); the continuous stream of processed environment,while its weight changes on unit length slowly along a screw and moves with permanent relative (in relation to working screw) speed.

A mathematical model takes into account the limitation and supposition for the existent screw conveyer with the length of 2,5 and $3 \mathrm{~m}$, which is used for moving the friable loads with the consistence of $10,20,40 \mathrm{~kg} / \mathrm{m}$. The alternative parameters are the length of the screw,the consistence of the processed environment, the speed of circulation ofthe screw, weight

On the basis of model the dependences of amplitude of vibrations on the lengthof screw, cosistence of the processed environment, the speed of circulation of the screw, weight are built.

Conclusions. A mathematical model allows to improve the process of development and designing of the screw conveyers of the friable loads providing the reliability of process of transportion and system "the processed environment - the screw working part". 


\section{Introduction}

Presently screw conveyers are the part of complex mechanization and automation of manufacturing. Creation of new and improvement of the existent constructions ofscrew conveyers with the extended technological possibilities assists to further development of production and increase of their efficiency of the usige. In the modern constructions of cars the usige of screw mechanisms, the nomenclature of which and the specific of exploitation grow constantly; specific weight of these mechanisms in lift-shifting cars according to the different amounts $40 . .45 \%$ It is established that functional possibilities and technological characteristics of some screw conveyers don't comply the requirements of present time fullyaccording to the signs of expansion of nomenclature of technological processes; results of theoretical and experimental researches, bench equipment etc.. Accordingly the problem of development of the theory and methods of planning of screw conveyers and their descriptions is especially actual has the important value for the economy of the country.

Analysis of the last researches and publications. The conducted analysis of the state of the modern technologies and literary-patent search of constructions of cars and mechanisms for realization of transporting of friable materials [1-3] has showed that in one or another measure they satisfy considerable part of requirements which are pulled out to them, however most constructions of working of working parts of conveyers carry out not only the forward axial moving of material but also implementation of circulating motion, that reduces productivity of such mechanisms. They have a simple construction maximum, differ in acompactness and they are reliable in exploitation. At the same time, the substantial disadvantage ofscrew mechanisms is reduction of their productivity at large frequencies of rotation as a result of increasing of centrifugal forces in the zone of loading that leads to increase of power-hungryness of process of transporting such kinds of devices.

In works [4-8] it was used the method of discrete elements for the analysis of the productivity of screw conveyer including visualization of motion of particles, the angular and axial speed of particles and on the whole twisty moment and total force. It is built the model by application of its periodic border for one step of screw and the particle of friable material, it is shown the dependence of the productivity ofscrew conveyer on operating conditions. It is set that the equability of the stream depends on the construction ofscrew working part and bunker, form of the particles and the force of the friction to walls. The results of this research can present better the usige of screw feeders for specific materials. In-works [9-13] it was conducted the experiment for determination influence of parameterswhich have the most influence on horizontal screw conveyers and also power consumption at transporting of grains.So, in works [14] it is adduced the results of researches saving transporting of agricultural materials on the horizontal and aslope located screw working parts, character of motion of stream of material at its loading [15] and overload ing [16], and also moving material by the vertical screws [17] which it is expedient to take into account during realization of researches of moving of stream of root crops and their cleaning.

Experimental and separate theoretical researches of the dynamics of working parts of screw conveyers [18-19], moving of the processed environment along the last items influence on quantitative and on the other occasion and quality descriptions of their vibrations. Thus, influence of dynamics of environment grows with the increasing of the amount of its relative motion toward the screw working part. At the same time the intensive vibrations of screw working part lead to the considerable increase of dynamic tensions, and as a result to reduction of operating term of work of machine. At certain conditions of exploitation of screw conveyers it can take place both the internal and "external 
"resonances. Envisaging them is possible only on the base of analysis of decisions of mathematical models which are adequate to dynamic process.

At the same time the questions of the influence of the relative motion of processed environment on the turning vibrations of working part which are important for the assement of work of screw conveyer have not found the proper illustration in literature.For their solution of this task there is a mathematical model of vibrations of working part of screw conveyer for transporting friable loads taking into account the change of consistence of the processed environment, the speed of circulation of screw, mass at appearance of thephenomenon of the resonance.

\section{Materials and methods}

\section{Materials}

The object of the research is the working part of multifunctional screw conveyer which is used for transporting of friable materials (forage, chemicals, powders, supplements, etc ). The subject of the research is turning vibrations of screw working part of screw multifunctional conveyer which arise up as a result of action of processed environment.

\section{Description of the device}

The auger compensating multifunctional conveyor is made in the form of a casing 1 with both front 2 and rear 3 supports. Their height can be changed in order to transport materials horizontally and at an angle. The fixed cone trough 4 is firmly fixed to these two supports in several variants - the solid one and with the system of through-holes in its lower part made in a known way. Inside the fixed conical body 4, a conical screw working element 5 with variable steps is installed in the bearing units with the possibility of turning and axial displacement. The bearing bushes 5 are welded to the left 2 and the right 3 supports; in their central openings, the movable cylindrical blocks 6 are set. The bearings are rigidly installed in the middle of blocks; the internal holes of bearing are in contact with the shaft 7 ends of the conical auger 5 with the possibility of axial displacement.

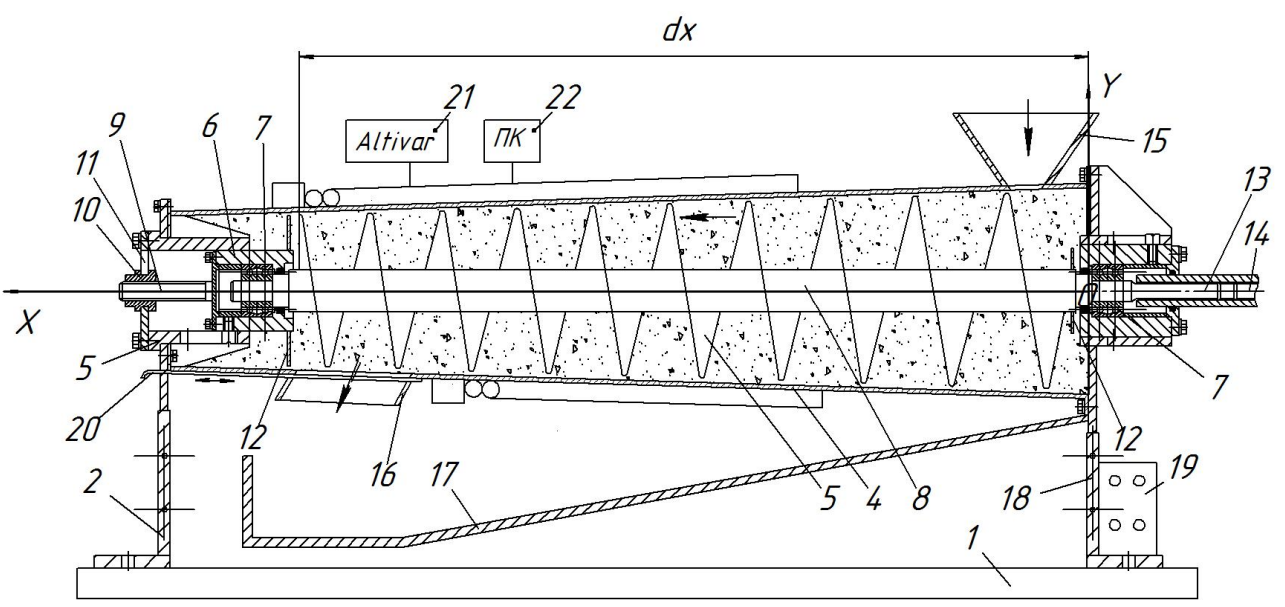

Figure 1. Schematic construction of the auger compensating multifunction conveyor 
The ends of movable blocks 6 are covered with lids. A screw 9 is rigidly welded to the left lid 8 of the cylindrical block 6 . The screw is in contact with the adjusting nut 10 , which is firmly mounted in the axial groove of the lid 11 of the movable cylinder block 6 . In addition, the stopper 13 are firmly fixed to the left and right ends of the shaft 7 of the cylindrical movable block 6 . They prevent the movement of transport mass beyond the screw working body.

Similarly, at the right end of the screw cone working body, the structure is the same, but the difference is that the ends of the shaft 7 are made with an elongated cut 14, to which the drive shaft 15 of the conveyor is connected. In the loading zone, the boot pipe 16 is installed, and in the unloading zone, the discharge nozzle 17 is installed as well. To fix the screw conical working body 5 , in the moving blocks 6 , the axial slots 19 are made with screw fixing elements 20 . The system is controlled from the console 21 .

\section{Results and discussion}

\section{Formulation of the problem}

In case of the screw working body, the task is considerably complicated: firstly, due to the uneven distribution of the medium along the auger length; secondly, the body performs bending oscillations; thirdly, the movement of the processed medium along the working screw, which carries even small bending oscillations, causes the occurrence of 'additional forces', which moments must be factored in the differential equation of torsional oscillations of the system 'processed environment - screw working body'. Thus, in order to study the torsional oscillations of the screw conveyor working body, a 'refined' differential equation of the indicated oscillations should be deduced.

\section{Basic assumptions about the object under study}

a. The working auger screw rotates with a constant angular velocity $\Omega$ around its longitudinal axis, which in the undeformed position coincides with the axis $O X$;

b. The transverse movement of the neutral axis of the working screw at an arbitrary moment in the direction perpendicular to its undeformed position is determined (with respect to the fixed reference frame of the OXYZ) by the vector $\vec{r}=u(x, t) \vec{j}+w(x, t) \vec{k} ;$

c. A continuous flow of the processed medium, which mass per unit length $m$ slowly varies along the length of the screw $(m=m(x))$ and moves with a constant relative (relative to the working auger screw) velocity $V$.

\section{Mathematical model solution}

A differential equation with partial derivatives is known to be a mathematical model of torsional oscillations of a rectilinear body

$$
I \frac{\partial^{2} \theta}{\partial t^{2}}-\frac{\partial}{\partial x}\left(G J \frac{\partial \theta}{\partial x}\right)=Q\left(\theta, \frac{\partial \theta}{\partial t}, \frac{\partial \theta}{\partial x}, \phi\right)
$$

under boundary conditions, which are consistent with the method of body fixation. In Eq. (1) $\theta(x, t)$ - the angle of twisting the elastic body, $I$ - the length moment of inertia relative 
to the axis of rotation, $G$ - the shift module, $J$ - the equatorial moment of the cross section, $Q\left(x, \theta, \frac{\partial \theta}{\partial t}, \frac{\partial \theta}{\partial x}, \phi\right)$ - the nonlinear in conjunction with a set of variables $\theta, \frac{\partial \theta}{\partial t}, \frac{\partial \theta}{\partial x}$ periodic by $\phi=\eta t+\phi_{0}$ function that describes the distribution of external forces moments along the body length relative to the axis of rotation (including the moments of resistance), and $\eta$ - the frequency of periodic perturbation.

In this case, the inertia force [20] of the conditionally selected element of the screw, the working medium of the length $d x$ and its moment relative to the axis of rotation are determined in accordance with the dependencies

$$
\begin{gathered}
\vec{\Phi}_{m .}=2\left(m+m_{1}\right) \Omega\left(\frac{\partial w}{\partial t} \vec{j}-\frac{\partial u}{\partial t} \vec{k}\right) d x \\
M_{m .}^{\Phi} \vec{i}=(u \vec{j}+w \vec{k}) \times \vec{\Phi}_{m .}=-2\left(m+m_{1}\right) \Omega\left(u \frac{\partial u}{\partial t}+w \frac{\partial u}{\partial t}\right) \vec{i} d x,
\end{gathered}
$$

where $m_{1}=m_{1}(x)$ - the mass per unit length of the auger conveyor crew.

Similarly, the inertia force of the processed medium and its moment relative to the axis of rotation is defined, taking into account the medium motion along the deformed screw

$$
\begin{gathered}
\vec{\Phi}_{\text {cep. }}=2 m \Omega V\left(\frac{\partial w}{\partial x} \vec{j}-\frac{\partial u}{\partial x} \vec{k}\right) d x . \\
M_{\text {cep. }}^{\Phi} \vec{i}=(\overrightarrow{u j}+w \vec{k}) \times \vec{\Phi}_{\text {cep. }}=-2 m \Omega V\left(u \frac{\partial u}{\partial x}+w \frac{\partial w}{\partial x}\right) \vec{i} d x .
\end{gathered}
$$

Other inertia forces of the processed medium continuous flow are not considered. The moment of the forces relative to the rotational axis of the working screw is zero and therefore does not affect its torsional oscillations. The above allows presenting a refined differential equation of torsional oscillations of the system 'processed medium continuous flow - screw working body'

$$
\begin{gathered}
\frac{\partial^{2} \theta}{\partial t^{2}}-\frac{G J_{0}}{I_{0}} \frac{\partial^{2} \theta}{\partial x^{2}}=\frac{1}{I_{0}} f\left(x, \theta, \frac{\partial \theta}{\partial t}, \frac{\partial \theta}{\partial x}, \phi\right) \\
\frac{G J_{0}}{I_{0}}=\frac{G}{\rho}
\end{gathered}
$$

where:

$$
f\left(x, \theta, \frac{\partial \theta}{\partial t}, \frac{\partial \theta}{\partial x}, \phi\right)=Q\left(x, \theta, \frac{\partial \theta}{\partial t}, \frac{\partial \theta}{\partial x}, \phi\right)-2 \Omega\left[\left(m+m_{1}\right)\left(u \frac{\partial u}{\partial t}+w \frac{\partial w}{\partial t}\right)+m V\left(u \frac{\partial u}{\partial x}+w \frac{\partial w}{\partial x}\right)\right]
$$

$G$ - the shift module, $I_{0}$ - the length moment of the inertia relative to the axis of a working screw together with the processed medium, $J_{0}$ - the equatorial moment of the working screw cross-section and the values below are considered constant.

Further calculations relate to the development and study of the differential equation solution (6) under boundary conditions 


$$
\theta(x, t)_{\mid x=0}=\theta(x, t)_{\mid x=l}=0
$$

which correspond to the twisting oscillations of the auger working body with free ends, and $l-$ the distance between the bearings, in which it rotates. Based on the following physically grounded statements, the boundary problem Eq. (6), Eq. (7) can be solved:

1. The maximum value of the right-hand side of differential equation Eq. (6) is a small value in comparison with the maximum value of the 'restoring moment of torsion', that is, the second summand of its left-hand side;

2. Functions of the deflection $u(x, t), w(x, t)$ of the screw working body are determined [21] by a wave form with an amplitude $a$, a wave number $\lambda_{k}=\frac{k \pi}{l}$, a frequency $\omega_{k}=\sqrt{\left(\frac{k \pi}{l}\right)^{4} \frac{E \bar{I}_{0}}{m+m_{1}}-\Omega^{2}}, \bar{I}_{0}$ - the inertia moment of the working screw crosssection relative to the neutral axis of the cross-section, which is perpendicular to the plane of oscillation. In this case, the right-hand side of differential equation Eq. (6) can be presented in the form

$$
f(x, \theta, \ldots, \phi)=Q(x, \theta, \ldots, \phi)-4 \Omega a^{2}\left(2\left(m+m_{1}\right) \omega_{k} \sin ^{2} \lambda_{k} x \sin 2 \psi_{k}+m V \lambda_{k} \sin 2 \lambda_{k} x \cos 2 \psi_{k}\right), \psi_{k}=\omega_{k} t+\psi_{0}
$$

where $\psi_{0}$ - a constant. Thus, the problem solution was reduced to developing a solution of differential Eq. (6), considering Eq. (8) under boundary conditions Eq. (7).

The most effective methods of studying 'weakly nonlinear' oscillatory systems with lumped masses or distributed parameters are methods based on the main idea of perturbation methods [22-25]. In relation to the considered problem, the application of the principle of one-frequency oscillations and the basic idea of the Bubnov Galerkin method [21, 29-30] allow reducing the boundary problem Eq. (6), Eq. (7) to integration of the system of ordinary quasilinear differential equations

$$
\begin{aligned}
& \ddot{T}_{1}(t)+\left(\frac{\pi}{l}\right)^{2} \frac{G J_{0}}{I_{0}} T_{1}=\frac{1}{l I_{0}}\left\{\int_{0}^{l} Q\left(x, T_{1} \sin \frac{\pi}{l} x, \ldots, \phi\right) \sin \frac{\pi}{l} x d x-\frac{16 l}{3 \sqrt{\pi}} \Omega a^{2}\left(m+m_{1}\right) \omega_{1} \sin 2 \psi\right. \\
& T_{2}(t)+\left(\frac{2 \pi}{l}\right)^{2} \frac{G J_{0}}{I_{0}} T_{2}=\frac{1}{l I_{0}}\left\{\int_{0}^{l} Q\left(x, T_{2} \sin \frac{2 \pi}{l} x, \ldots, \phi\right) \sin \frac{2 \pi}{l} x d x-4 \Omega a^{2} l m V \cos 2 \psi\right.
\end{aligned}
$$

Based on dependences Eq. (9), Eq. (10), the most interesting cases of torsional oscillations from the theoretical and practical point of view are cases:

$$
\begin{gathered}
\text { a. } \frac{\pi}{l} \sqrt{\frac{G J_{0}}{I_{0}}} \approx \sqrt{\left(\frac{2 \pi}{l}\right)^{4} \frac{E \bar{I}_{0}}{m+m_{1}}-\Omega^{2}}, \quad \text { b. } \frac{2 \pi}{l} \sqrt{\frac{G J_{0}}{I_{0}}} \approx \sqrt{\left(\frac{2 \pi}{l}\right)^{4} \frac{E \bar{I}_{0}}{m+m_{1}}-\Omega^{2}}, \\
\text { c. } \frac{k \pi}{l} \sqrt{\frac{G J_{0}}{I_{0}}} \approx \eta .
\end{gathered}
$$


These cases are called resonant. The case (c) is defined by external factors, then, the cases (a) and (b) - by bending oscillations of the working screw. In addition, the case (a) considers purely bending oscillations and rotations of the working screw, then, the case (b) - the processed medium additional motion along the working screw, more precisely, the moment relative to the rotation axis of the Coriolis force of the inertia of the processed medium.

\section{Mathematical model discussion}

According to individual studies [26-28], combination resonances of higher orders are less important than the above-mentioned ones;

The methods of studying the resonance phenomena on different frequencies do not fundamentally differ. Therefore, the general statements based on the generalization of the main idea of the Van der Pol method to the differential equation Eq. (9) or Eq. (10) are presented.

Thus, the resonance oscillations under the conditions a), b), c) are described by the dependence $T_{i}(t)=\bar{a}_{i}(t) \cos \left(\bar{\omega}_{i} t+\vartheta_{i}(t)\right)$, where $\bar{\omega}_{i}$ is one of the frequencies, on which resonance oscillations are considered, and the parameters $\bar{a}_{i}(t)$ and $\vartheta_{i}(t)$ (the amplitude and phase difference of resonant oscillations) are determined by the differential equations:

a. For the resonance at the first angular rotation velocity of the screw working body

$$
\begin{gathered}
\frac{d a_{1}}{d t}=\frac{1}{2 \pi^{2} \bar{\omega}_{1} l I_{0}} \int_{0}^{l} \int_{0}^{2 \pi} \int_{0}^{2 \pi} Q\left(x, \bar{a}_{1} \sin \frac{\pi}{l} x \cos \psi, \ldots, \phi\right) \sin \frac{\pi}{l} x \sin \varphi d x d \varphi d \phi- \\
-\frac{16 l}{3 \bar{\omega}_{1} I_{0}} \Omega_{1} a^{2}\left(m+m_{1}\right) \omega_{1} \cos \gamma_{1}, \\
\frac{d \gamma_{1}}{d t}=\frac{\pi}{l} \sqrt{\frac{G J_{0}}{I_{0}}}-\sqrt{\left(\frac{2 \pi}{l}\right)^{4} \frac{E \bar{I}_{0}}{m+m_{1}}-\Omega_{1}^{2}}+ \\
+\frac{1}{2 \pi^{2} \bar{\omega}_{1} \bar{a}_{1} l I_{0}} \int_{0}^{l} \int_{0}^{2 \pi} \int_{0}^{2 \pi} Q\left(x, \bar{a}_{2} \sin \frac{\pi}{l} x \cos \psi, \ldots, \phi\right) \sin \frac{\pi}{l} x \cos \varphi d x d \varphi d \phi+\frac{16 l}{3 \bar{\omega}_{1} \bar{a}_{1} I_{0}} \Omega_{1} a^{2}\left(m+m_{1}\right) \omega_{1} \sin \gamma_{1} ;
\end{gathered}
$$

b. For the resonance at the second angular rotation velocity of the screw working body

$$
\begin{gathered}
\frac{d a_{2}}{d t}=\frac{1}{2 \pi^{2} \bar{\omega}_{2} l I_{0}} \int_{0}^{l} \int_{0}^{2 \pi} \int_{0}^{2 \pi} Q\left(x, a_{1} \sin \frac{2 \pi}{l} x \cos \psi, \ldots, \phi\right) \sin \frac{2 \pi}{l} x \sin \varphi d x d \varphi d \phi+ \\
+\frac{2 \Omega_{2} a^{2} V l m \pi}{\bar{\omega}_{2} I_{0}} \sin \gamma_{2}, \\
\frac{d \gamma_{2}}{d t}=\frac{2 \pi}{l} \sqrt{\frac{G J_{0}}{I_{0}}}-\sqrt{\left(\frac{2 \pi}{l}\right)^{4} \frac{E \bar{I}_{0}}{m+m_{1}}-\Omega_{2}^{2}}+ \\
+\frac{1}{2 \pi^{2} \bar{\omega}_{2} \bar{a}_{2} l I_{0}} \int_{0}^{l} \int_{0}^{2 \pi} \int_{0}^{2 \pi} Q\left(x, a_{2} \sin \frac{\pi}{l} x \cos \psi, \ldots, \phi\right) \sin \frac{\pi}{l} x \cos \varphi d x d \varphi d \phi-\frac{2 \Omega_{2} a^{2} V l m \pi}{\bar{\omega}_{2} \bar{a}_{2} I_{0}} \cos \gamma_{2} ;
\end{gathered}
$$


c. For the resonance on the frequency of the external periodic perturbation

$$
\begin{aligned}
& \frac{d \bar{a}_{3}}{d t}=\frac{1}{2 \pi l \mu I_{0}} \int_{0}^{l} \int_{0}^{2 \pi} Q\left(x, \bar{a}_{3} \sin \frac{\pi}{l} x \cos \left(\gamma_{3}+\varphi\right), \ldots, \varphi\right) \sin \left(\gamma_{3}+\varphi\right) \sin \frac{\pi}{l} x d x d \varphi \\
& \frac{d \gamma_{3}}{d t}=\frac{\pi}{l} \sqrt{\frac{G J_{0}}{I_{0}}}-\mu+\frac{1}{2 \pi l \bar{\omega}_{1} I_{0} \bar{a}_{3}} \int_{0}^{l} \int_{0}^{2 \pi} Q\left(x, \bar{a}_{3} \sin \frac{\pi}{l} x \cos \left(\gamma_{3}+\varphi\right), \ldots, \varphi\right) \cos \left(\gamma_{3}+\varphi\right) \sin \frac{\pi}{l} x d x d \varphi \\
& \text { where } \bar{\omega}_{1}=\frac{\pi}{l} \sqrt{\frac{G J_{0}}{I_{0}}}, \bar{\omega}_{2}=\frac{2 \pi}{l} \sqrt{\frac{G J_{0}}{I_{0}}} .
\end{aligned}
$$

Consequently, the internal resonances occur only due to a certain correlation between the frequency of the own transverse and torsional oscillations, more precisely, due to the distribution of masses in the system 'processed medium - auger working body', its geometrical dimensions and the angular velocity of the working screw. According to equations Eq. (11) and Eq. (12), in Figure 1 and Figure 2, under the condition $Q=Q\left(x, \theta, \frac{\partial \theta}{\partial x}, \frac{\partial \theta}{\partial t}, \phi\right)=\delta\left(\frac{\partial \theta}{\partial t}\right)^{s}(\delta, s-$ steels $)$, the amplitudes of torsional oscillations of the working screw during the transition through the resonance are presented for different lengths of the working screw, and different values of its densities (see figure 1), and different values of masses per unit length of the processed medium and its velocity (see Figure 2).

On the basis of theoretical data it is shown the results of experimental researches of dependence of the productivity of the inclined іскуц conveyer from the internal diameter of casing of $D$, epy angle of slope of conveyer $\gamma$ and frequency of rotation of working part $n$ during the transporting of friable material (wheats). It is deduced the equation of regression for determination the productivity of transportion of wheat.

During transportion of wheat :

$$
Q_{(D, \gamma, n)}=3,387-117,52 D+2,49 \cdot 10^{-2} \gamma-8,92 \cdot 10^{-3} n-0,328 D \gamma++0,234 D n-3,4 \cdot 10^{-5} \gamma n+880 D^{2}
$$

On the basis ofthe experemental researches it was set the maximal value of the productivity $-6,4 \mathrm{t} / \mathrm{hour}$, and minimum $-0,2 \mathrm{t} / \mathrm{hour}$. The basic factors which influence on increasing the productivity are the external diameter of screw working part and amount of turns and at the increase of angle of slope of conveyer the productivity is reducing. 


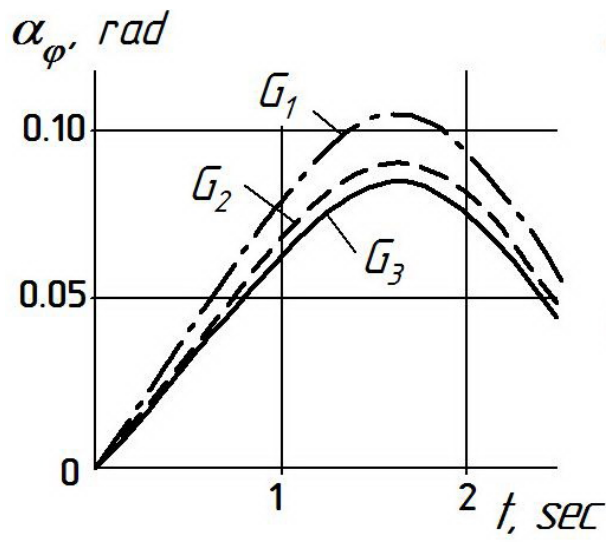

$a$

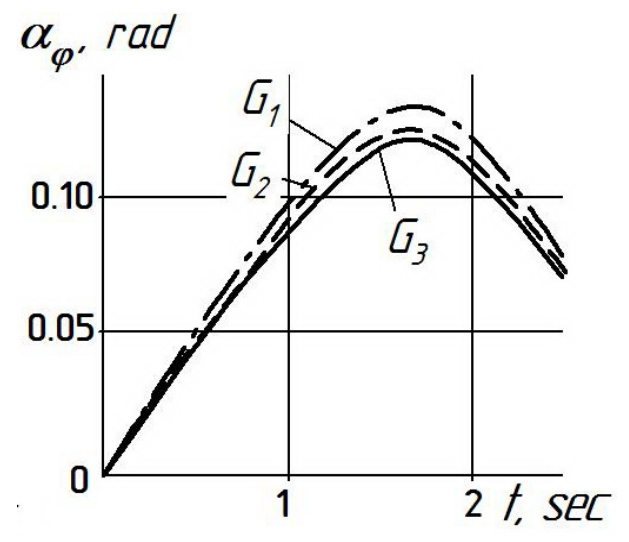

b

$$
\begin{gathered}
m=m_{1}=10 \mathrm{~kg} / \mathrm{m}, E=2 \cdot 10^{11} \mathrm{MN} / \mathrm{m}^{2}, \\
\bar{I}_{0}=2.78 \cdot 10^{-7} \mathrm{~m}^{4}, G_{1}=1.6 \cdot 10^{11} \mathrm{MN} / \mathrm{m}^{2}, \\
G_{2}=1.4 \cdot 10^{11} \mathrm{MN} / \mathrm{m}^{2}, G_{3}=1.3 \cdot 10^{11} \\
\mathrm{MN} / \mathrm{m}^{2}, l=2.5 \mathrm{~m}
\end{gathered}
$$

Figure 2. Change in the amplitude of torsional oscillations of the working screw during the transition through the resonance on the first frequency of transverse oscillations under the following values of parameters

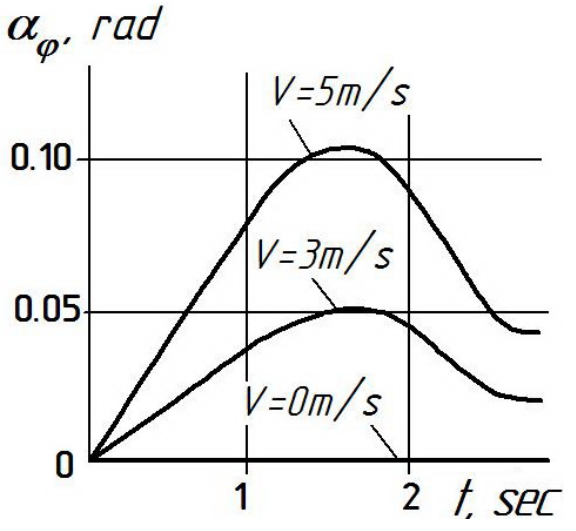

a

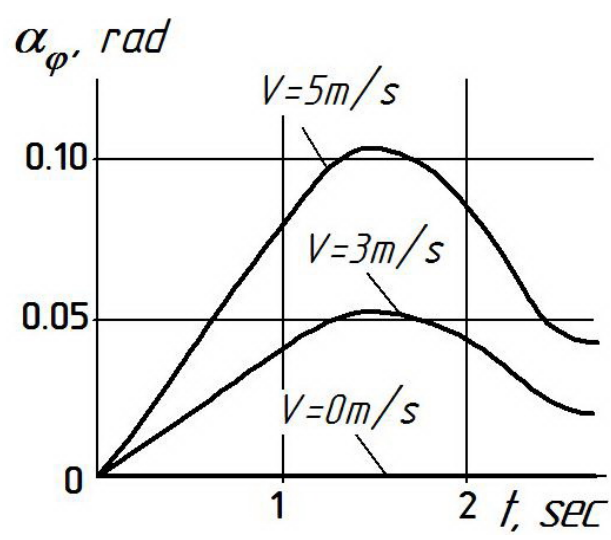

b

$m=40 \mathrm{~kg} / \mathrm{m}, \quad m_{1}=10 \mathrm{~kg} / \mathrm{m}, \quad E=2 \cdot 10^{11} \quad m=20 \mathrm{~kg} / \mathrm{m}, \quad m_{1}=10 \mathrm{~kg} / \mathrm{m}, \quad E=2 \cdot 10^{11}$ $\mathrm{MN} / \mathrm{m}^{2}, \bar{I}_{0}=2.78 \cdot 10^{-7} \mathrm{~m}^{4}, G_{1}=1.3 \cdot 10^{11} \mathrm{MN} / \mathrm{m}^{2}, \quad \bar{I}_{0}=2.78 \cdot 10^{-7} \mathrm{~m}^{4}, \quad G_{1}=1.3 \cdot 10^{11}$ $\mathrm{MN} / m^{2}, l=3 m$ $\mathrm{MN} / m^{2}, l=3 m$

Figure 3. Change in the amplitude of torsional oscillations of the working screw during the transition through the resonance on the second frequency of transverse oscillations under the following values of parameters 


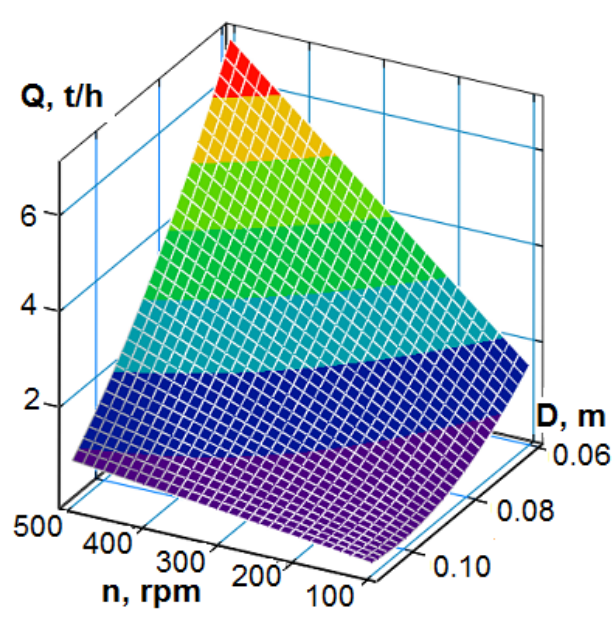

$\boldsymbol{a}$

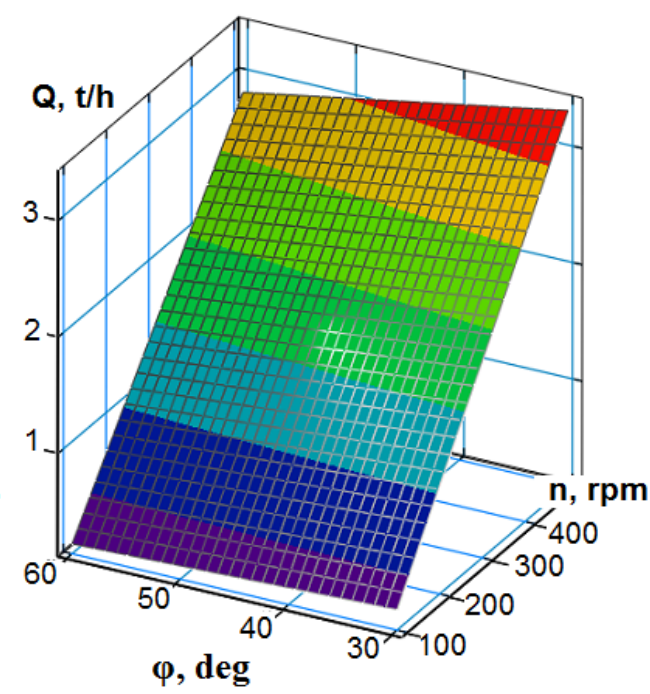

$b$

Figure 4 . Surface of review of the change of the productivity of conveyer $Q$ during transportion as a functional:

$$
\mathbf{a}-Q=f_{(Q)}(D ; n) ; \quad \mathbf{b}-Q=f_{(Q)}(n ; \gamma)
$$

\section{Conclusions}

Based on the developed method of studying the torsional oscillations of the screw working auger conveyor with consideration of its transverse oscillations and the motion of the processed medium continuous flow, the following conclusions are made:

1. The constant angular rotation velocity of the screw working body decelerates the frequency of the own bending oscillations of the screw working body;

2. Relative movement of the processed medium along the screw working body, which rotates and performs transverse oscriblations, acts additionally on the body as the periodic torque;

3. According to the above-mentioned, the resonances can occur during the torsional oscillations of the screw working body on the first fundamental and the second frequencies of the twisting oscillations of the working body and on the frequency of external periodic perturbation;

4. The amplitude of the transition through the resonance on the fundamental frequency of bending oscillations assumes smaller value for screw working bodies with greater torsional rigidity;

5. The amplitude of torsional oscillations during the transition through the resonance on the second fundamental frequency is higher due to the larger values of the quantity of processed medium relative motion; 
6. The amplitude of torsional oscillations during the 'fast' transition through the resonance on the frequency of external or internal perturbations is smaller than during the 'slow' one.

The obtained results can serve as a basis for choosing the basic technological and operational parameters of a screw multifunctional conveyor. The results reliability is confirmed by obtaining in the limiting case under $V \rightarrow 0$ the known [3], which relate to the influence of bending oscillations of the elastic screw on the torsional ones, without considering the motion of the processed medium.

The results of modeling correlate (call) with the results of researches [1, 8, 15, 21, 29]. The received results should be followed for further planning the similar screw conveyers with similar changeable parameters.

\section{References}

1. Hu G., Chen J., Jian B., Wan H., Liu L., (2010), Modeling and simulation of transportation system of screw conveyors by the discrete element method. International Conference on Mechanic Automation and Control Engineering, MACE 2010, Article number 5536244, pp. 927-930.

2. Zareiforoush H., Komarizadeh M.H., Alizadeh M.R., (2010), Effect of crop-screw parameters on rough rice grain damage in handling with a horizontal screw conveyor. Journal of Food, Agriculture and Environment, 8(3-4), pp. 494-499.

3. Fernandez J. W., Cleary P.W., McBride W., (2009), Effekt of screw desing on hopper draw dawn by a horizontal screw feeder, Seventh International Conference on CFD in the Minerals and Process Industries CSIRO, Melbourne, Australia 9-11 Decem, pp. 1-6.

4. Zareiforoush H., Komarizadeh M.H., Alizadeh M.R., (2010), Screw conveyors power and throughput analysis during horizontal handling of paddy grains, Agricultural Science, 2(2), pp. $147-157$.

5. Roberts A.W., Bulk Solids, (2015), Optimizing Screw Conveyors, Chemical engineering, 122(2), pp. 62-67.

6. Yao Y.P., Kou Z.M., Meng W.J., Han G., (2014), Overall Performance Evaluation of Tubular Scraper Conveyors Using a TOPSIS-Based Multiattribute Decision-Making Method, The Scientific World Journal.

7. Owen P.J., Cleary P.W., (2010), Screw conveyor performance: comparison of discrete element modelling with laboratory experiments, Progress in computational fluid dynamics, 10(5-6), pp. 327-333.

8. Manjula E. V. P. J., Ariyaratne W. H., Ratnayake, C., \& Melaaen, M. C., (2017), A review of CFD modelling studies on pneumatic conveying and challenges in modelling offshore drill cuttings transport, Powder Technology, 305, pp. 782-793.

9. Tripathi N., Sharma A., Mallick S. S., Wypych P. W., (2015), Energy loss at bends in the pneumatic conveying of fly ash. Particuology, 21, pp. 65-73.

10. Xiaoxia S., Wenjun M., Yuan Y., (2017), Design method of a vertical screw conveyor based on Taylor-Couette-Poiseuille stable helical vortex. Advances in Mechanical Engineering, 9(7), 1687814017714984.

11. Tian Y., Yuan P., Yang F., Gu J., Chen M., Tang J., ... Cheng Q., (2018), Research on the Principle of a New Flexible Screw Conveyor and its Power Consumption. Applied Sciences, 8(7), pp. 1038.

12. Chen L. Q., Wang B., \& Ding H., (2009), Nonlinear parametric vibration of axially moving beams: asymptotic analysis and differential quadrature verification, In Journal of Physics: Conference Series, 181(1), pp. 1-8. 
13. Hevko R.B., Synii S.V., Pankiv M.R., Varholiak M.A., (2014), Development and Analysis of Machine Operation for Energy Saving Technologies of Root Crop Harvesting, Bulletin of Engineering Academy of Ukraine, 4, pp. 46-52.

14. Lyashuk O.L., Rogatynska O.R., Serilko D.L., (2015), Modelling of the vertical screw conveyer loading, INMATEH: Agricultural Engineering, 45, pp. 87-94.

15. Hevko R.B., Tkachenko I.H., Synii S.V., Flonts I.V., (2016), Development of design and investigation of operation processes of small-sclale root crop and potato harvesters. INMATEH: Agricultural engineering, 49, pp. 53-60.

16. Lyashuk O.L., Sokil M.B., Dovbush A.P., (2016), Dynamics of flexible elements of drive systems with variable contact point to the pulleys. INMATEH: Agricultural Engineering, 48, pp. 119-124.

17. Hevko I., Lobachivskyi R., Diachun A., (2011), Experimental investigations of mixing the bulk materials with a mixer by pouring them into another container, Interuniversity Collection ("Engineering Mechanics") "Scientific Notes" LNTU, 5, pp. 51-55.

18. Lyashuk O., Pyndus T., Marunych O., Sokil M., (2016), Longitudinal-angular oscillation of wheeled vehicles with non-linear power characteristics of absorber system, Scientific Journal of the Ternopil National Technical University, 83(2), pp. 82-89.

19. Pavlovskiy M. A., Putiata T. V., (1985), Theoretical mechanics, Kyiv, Ukraine.

20. Rohatynskyi R. M., (2014), Scientific and Applied Fundamentals for Creation of Screw Transport and Technological Mechanisms, Ternopil, Ukraine: Publishing house of TNTU.

21. Mitropolskiy Yu. A., Moseyenkov B. I., (1976), Asymptotic solutions of partial differential equations, Kyiv, Ukraine.

22. Stotsko Z., Sokil B., Topilnytskyj V., (2000), Das Unlinear parametrischmodell der Dreimassenmaschienen fur die Vibrationsvolumenbehandlung und ihre Streuladung, Kwartalnik Naukowo-Techniczny Maszyny Dzwigowo-Transportowe, 3, pp. 50-62.

23. Stotsko Z.A., Sokil B., Topilnytskyj V., (2007), Complex mathematical model and optimization of vibration volumetric treatment for surfaces of machine parts, J. of Achievements in Materials and Manufacturing Engineering, 24, pp. 283-290.

24. Hevko B.M., Pavel'chuk Yu.F., (2017), Modeling the fluctuations of the mechanical system of a suspension hole: theoretical analysis, Innovative solutions in Modern Science, 10(1), pp. 1-9.

25. Geruk S.M., Dovbysh A.P., (2016), Influence of vibration separator oscillations perturbations on the grain mixture dynamics, Construction, production and operation of agricultural machinery, 46, pp. 124-132.

26. Kuzio I.V., Kharchenko Ye. V., Sokil M. B., (2007), Dynamic processes in environments characterized by longitudinal motion and the effect of boundary conditions on the amplitude and frequency of their oscillations, Vibration in techniques and technology, 48(3), pp. 53-56.

27. Sokil M.B., Khytriak O.I., (2011), Wave theory of motion in the study of fluctuations of flexible drive elements and transportation factoring in their longitudinal motion, Military Technical Collection, 1, pp. 102-105.

28. Hevko, B., Lyashuk, O., Sokil, M., Skyba, O., Marunych, O., Shmatko, D., (2018), Dynamics of auger working body of a multifunctional conveyor. Bulletin of the Karaganda University. «Mathematics» series, 89(1), pp. 105-113.

29. Lyashuk O.L., Sokil M.B., Klendiy V.M., Skyba O.P., Slobodian L.M., (2018), Mathematical model of bending vibrations of a horizontal feeder-mixer along the flow of grain mixture, INMATEH: Agricultural engineering, 55(2), pp. 33-42. 


\title{
Effective robust optimal control system for a lamellar pasteurization-cooling unit under the conditions of intense external perturbations
}

\author{
Nataliia Lutska ${ }^{1}$, Nataliia Zaiets ${ }^{2}$, \\ Lidiia Vlasenko ${ }^{1}$, Volodymyr Shtepa ${ }^{3}$
}

1 - National University of Food Technologies, Kyiv, Ukraine

2 - National University of Live and Environment Sciences of Ukraine, Kyiv, Ukraine

3 - Polessky State University, Pinsk, Belarus

Keywords:

Robust

Optimal

2-riccati

Uncertainties

H2-regulator

Article history:

Received 04.06.2018

Received in revised form 19.08.2018

Accepted 28.09.2018

Corresponding author:

Nataliia Lutska

E-mail:

lutskanm2017@

gmail.com

DOI: $10.24263 / 2304-$

974X-2018-7-3-15

\section{Abstract}

Introduction. Investigated robust optimal control system of pasteurization-cooling unit, functioning under conditions of intensive external disturbances, information and structural uncertainty in order to improve the efficiency.

Materials and methods. Methods of system analysis, mathematical statistics and identification used to construct a mathematical model of the control object. For the synthesis of the robust optimal controller, the 2-Riccati approach $\mathrm{H}_{2}$ control problems is applied, and to reduce the order of the received regulator - method for balanced model reduction.

Results and discussion. The work of the pasteurization unit is considered, since it is a key component of dairy production. Since the results of the operation of traditional automated systems depend on the intensity and quality of information flows, microprocessor technology, algorithmic and software, it is proposed to supplement them with robust optimal controllers based on the 2-Riccati approach. Identified a mathematical model of the object, which consists of linear differential equations of the seventh order, it is possible to synthesize a robust optimal controller of the 6th order. Performance indicators are calculated by comparing the synthesized system and the system with local regulators. In a robust optimal system, the magnitude of uncertainty increased fourfold, and the dispersion of control signals decreased fourfold, which proves its energy efficiency.

Conclusion. The performed modeling and calculation of qualitative characteristics showed a significant advantage of the synthesized system in front of systems with local regulators. 


\section{Introduction}

During Industry 4.0, when industrial enterprises grow into Smart Factory, combine advanced production technologies, automated production, communications and information technologies, the issue of improving automated control systems of technological processes based on intelligent approaches is relevant $[1,25]$. However, in terms of automation, such managing facilities have common problems of mismatch in temperature and quality values, uneven consumption and temperature of the incoming flow, as well as other internal and external factors which negatively affect the quality of the output product and the energy efficiency of the whole system. All these factors can be described in the uncertainty range of the object, and then it is possible to construct a robust optimal control system under one correctly selected criterion [2-5].

For production objects with significant uncertainties of the use of $\mathrm{H}_{2}-$ or $\mathrm{H}_{\infty}$-norms of the Hardy space of the closed system transfer function as a control criterion are effective for the proper types of input and output signals, whereby the system obtains the property of low-sensitivity (robustness) towards internal and external object changes [6]. The control device thus synthesized has a high order, and as a result, the complexity of the software implementation.

Since the object of study works under conditions of parametric and structural uncertainty, as well as under the influence of intense external disturbances, the goal of the work is to increase the efficiency of its control system by synthesizing an effective control device based on robust optimal practices.

\section{Materials and methods}

According to the purpose of the article, the following approaches and methods were used: system approach, statistical analysis, parametric identification of dynamic mathematical models, synthesis of the $\mathrm{H}_{2}$-regulator in the 2-Riccati approach, reduction of mathematical models, mathematical modeling. Using the system approach [7, 8], the theoretical bases of the study, in particular, the orderly and structure of the model of the control object are well-documented. The statistical analysis of process variables substantiated the essence of uncertainties, and also helped shape the form of weight transfer functions for external perturbations [9, 10]. Identification methods [11, 12] are used to obtain approximate parameters of the mathematical model of an object with multiplicative uncertainty. The synthesized $\mathrm{H}_{2}$-regulator differs from the classical one in that additional input and output matrix transfer functions are used [13-15]. The latter are formed on the basis of a compromise between the quality of the system in nominal mode, the energy saving of the system and the robustness to internal changes in the object. The introduction of matrix weight transfer functions led to an increase in the order of the synthesized regulator, therefore a number of methods for reducing the order of the regulator were subsequently used [16-20].

Based on the results of mathematical modeling of systems with robust and local regulators $[21,22]$, the main characteristics of quality and stability were calculated and the response graphs of the systems were obtained for various types of perturbations. 


\section{Results and discussion}

\section{Analysis of the object of control, a mathematical model of an object}

Modern dairy plants throughout the country are mostly equipped with lamellar pasteurization-cooling units of various types and constructions. A lamellar pasteurizationcooling unit is intended for continuous heating and pasteurizing of milk, cream and other liquid food products without losing the main properties such as protein, sugar and molecules of fat. The concept of their performance lies in the series flow from one tank into another, gradually mixing with the already heated milk, and then the milk is heated and maintained during an appropriate period of time at the temperature of pasteurization. After heating, the product is cooled and forwarded to other stages of processing or packaging.

Figure 1 shows a simplified scheme of production flows of a typical lamellar pasteurization-cooling unit. Here $t_{1 \mathrm{r}}$ is the temperature of incoming raw milk, $t_{1 \mathrm{p}}$ is the temperature of pasteurized milk, $t_{1 \mathrm{w}}$ is the temperature of the heated milk, $t_{1 \mathrm{rec}}$ is the temperature of recuperated milk, $t_{10}$ is the temperature of cooled pasteurized milk, $t_{2 \mathrm{~h}}$ is the temperature of hot water, $t_{2 \mathrm{c}}$ is the temperature of cooled water, $m_{1}$ is the consumption of milk, $m_{2}$ is the consumption of hot water, $m_{3}$ is the consumption of iced water, $m_{4}$ is the consumption of steam.

Automatic temperature regime control of a lamellar pasteurization-cooling unit is reduced to two local loops of temperature control for pasteurized and cooled milk (PID or PI) with a stabilized input flow. In terms of automation, the control object is multiplyconnected, transient; the coordinates of the state are divided by spatial value, also, the object operates under permanent intensive external disturbances which are characterized by both deterministic and random components, the latter having a pigmented spectrum. In addition to the external perturbations which are shown in Figure 1, the quality of the output product is influenced by the acidity of the input product and the ambient temperature, which are not included into the control loop. Consequently, the use of the local regulators leads to quality degradation of the output product, and in some cases leads to repasteurization of the processed milk.

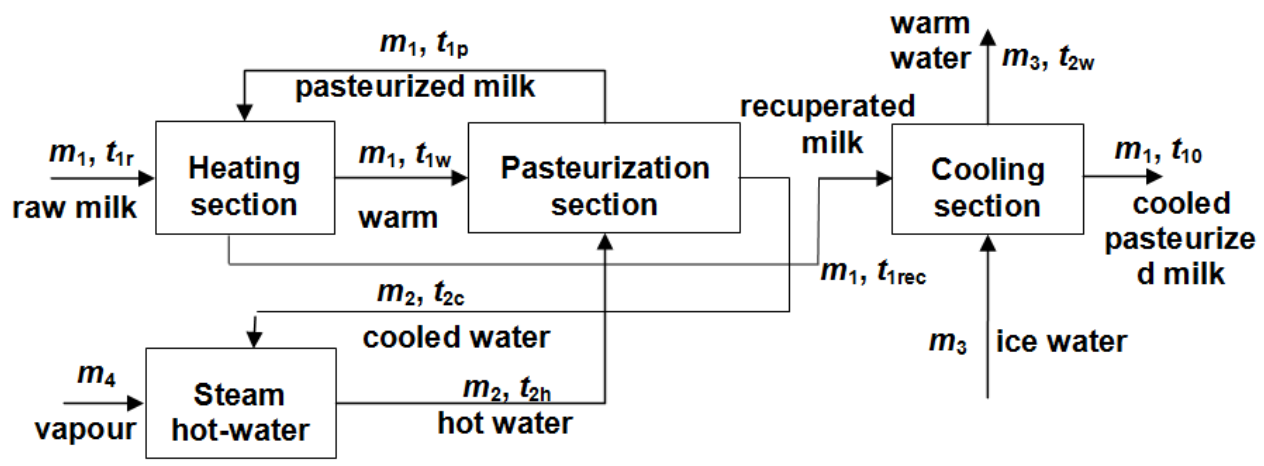

Figure 1. Scheme of the production flows in a lamellar pasteurization-cooling unit 
The problem of developing a mathematical model of a production process control object is still being controversial. For the synthesis of an effective control system, a mathematical model is to describe the object as best as possible, which leads to large orders of systems of differential equations, a complex description of parameters and traceability of a large number of external and internal variables in a production object, and consequently, to the complex and lengthy control algorithm, whereas simplifying the mathematical model reduces the quality of control [22]. Therefore, an alternative in developing the mathematical model of a production control object is using different types of uncertainties, which, on the one hand, simplifies the nominal model of an object, while taking into consideration the allowance in such description and changes in the object itself, on the other hand.

A lamellar pasteurization-cooling unit can be simply described by a system of differential equations of the $7^{\text {th }}$-order with a multiplicative type of uncertainty, including both parametric changes in an object and unmodulated dynamics, which appeared as a result of reducing the order of differential equations. Let's convert the model of a lamellar pasteurization-cooling unit to the space of state variables, taking into consideration the task signals in addition to the perturbations:

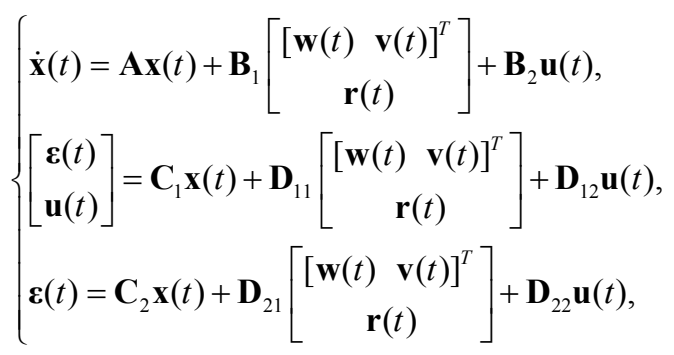

where $\quad \mathbf{x}(t)=\left[\Delta t_{\text {1rec }}, \Delta t_{1 w}, \Delta t_{1 p}, \Delta t_{2 c}, \Delta t_{10}, \Delta t_{2 w}, \Delta t_{2 h}\right]^{T}$ is a state coordinate vector; $\mathbf{u}(t)=\left[\Delta m_{3}, \Delta m_{4}\right]^{T}$ is a vector of control, $\mathbf{w}(t)=\left[m_{1}, m_{2}, \Delta t_{1 r}\right]$ is a vector of external perturbations; $\mathbf{v}(t)=\left[v_{1}(t), v_{2}(t)\right]$ is a vector of perturbations along the measuring circuit; $\mathbf{r}(t)=\left[\Delta r_{1}(t), \Delta r_{2}(t)\right]^{T}$ is a vector of the specified signals; $\mathbf{z}(t)=[\boldsymbol{\varepsilon}(t), \mathbf{u}(t)]^{T}$ is a vector of stabilized outputs; $\boldsymbol{\varepsilon}(t)=\mathbf{r}(t)-\mathbf{y}(t)$ is a vector of deviations from the specified signals; $\mathbf{y}(t)=\left[x_{3}(t), x_{5}(t)\right]^{T}$ is a vector of measurements.

All the matrix coefficients from (1) are determined on the basis of the aprior information about an object and as a result of identification [7-12]. The identification can be carried out by supplying pseudobinary signals to each input of the object and recording the output signals through the SCADA (Supervisory Control And Data Acquisition) program. The latter, through the PLC (Programmable Logic Controller) chain, is a field technology implemented by analog data transmission and industrial networks, receives information about the control object and executes a control signal. It is advisable to import the data into the Matlab software environment, where further processing will be carried out. Thus, for the A1-ОХЛ10 (OHL10) type lamellar pasteurization-cooling unit it is possible to determine and construct the basic matrix coefficients (1): 


$$
\begin{aligned}
& \mathbf{A}=10^{-2} \cdot\left[\begin{array}{ccccccc}
-23.31 & 0 & 20.75 & 0 & 0 & 0 & 0 \\
0 & -23.31 & 2.56 & 0 & 0 & 0 & 0 \\
0 & -2.25 & -22.47 & 0 & 0 & 0 & 24.72 \\
0 & 24.31 & 0 & -69.44 & 0 & 0 & 45.14 \\
3.07 & 0 & 0 & 0 & -10.57 & -54.02 & 0 \\
7.32 & 0 & 0 & 0 & 20.05 & -27.10 & 0 \\
0 & 0 & 0 & 19.16 & 0 & 0 & -19.16
\end{array}\right], \\
& \mathbf{B}_{1}=\left[\begin{array}{lll}
\mathbf{W}_{\mathbf{w}} \mathbf{B}_{1}^{\mathbf{w}} & \mathbf{B}_{1}^{\mathbf{v}} & \mathbf{B}_{1}^{\mathbf{r}}
\end{array}\right], \mathbf{B}_{1}^{\mathbf{v}}=\left[\mathbf{0}_{7 \times 2}\right], \mathbf{B}_{1}^{\mathbf{r}}=\left[\mathbf{0}_{7 \times 2}\right], \\
& B_{2}=\left[\begin{array}{cc}
0 & 0 \\
0 & 0 \\
0 & 0 \\
0 & 0 \\
0 & 0 \\
-4.078 & 0 \\
0 & 13.662
\end{array}\right] B_{2}=\left[\begin{array}{cc}
0 & 0 \\
0 & 0 \\
0 & 0 \\
0 & 0 \\
0 & 0 \\
-4.078 & 0 \\
0 & 13.662
\end{array}\right] \\
& \mathbf{C}_{1}=\left[\begin{array}{l}
-\mathbf{C}_{1}^{1} \\
\mathbf{0}_{2 \times 7}
\end{array}\right], \mathbf{C}_{1}^{1}=\left[\begin{array}{lllllll}
0 & 0 & 1 & 0 & 0 & 0 & 0 \\
0 & 0 & 0 & 0 & 1 & 0 & 0
\end{array}\right], \mathbf{C}_{2}=-\mathbf{C}_{1}^{1}, \\
& \mathbf{D}_{11}=\left[\begin{array}{ccc}
\mathbf{0}_{2 \times 3} & \mathbf{W}_{\mathbf{v}} \mathbf{I}_{2 \times 2} & \mathbf{I}_{2 \times 2} \\
& \mathbf{0}_{2 \times 7} &
\end{array}\right] ; \mathbf{D}_{12}=\left[\begin{array}{l}
\mathbf{0}_{2 \times 2} \\
\mathbf{I}_{3 \times 3}
\end{array}\right] ; \mathbf{D}_{21}=\left[\begin{array}{lll}
\mathbf{0}_{2 \times 3} & \mathbf{W}_{\mathbf{v}} \mathbf{I}_{2 \times 2} & \mathbf{I}_{2 \times 2}
\end{array}\right] ; \mathbf{D}_{22}=\left[\mathbf{0}_{2 \times 2}\right] .
\end{aligned}
$$

Here $\mathbf{0}_{i \times j}, \mathbf{I}_{i \times j}$ are zero and unity dimension matrices $i \times j$ respectively; $\mathbf{W}_{\mathbf{w}}, \mathbf{W}_{\mathbf{v}}$ are standardized weighting matrices of the intensity of external perturbations and noise measurements respectively. We might note that a control vector $\mathbf{u}(t)$ is additionally embedded into an output vector $\mathbf{z}(t)$ to restrict the signal of the former.

\section{Synthesis of a robust optimal regulator}

The functional chart of the control system is shown in Figure 2, where $\mathbf{G}(s), \mathbf{G}_{0}(s)$ are transfer functions of the uncertainty object and the nominal object accordingly, obtained from (1), and $\mathbf{K}(s)$ is a transferable function of the regulator, $\boldsymbol{\Delta}_{\mathbf{w}_{0}}(s)$ is a structural weighting uncertainty; $\mathrm{s}$ is a complex variable. Here, the mathematical model of the control object will be written as follows:

$$
\mathbf{G}(s)=\mathbf{G}_{0}(s)\left(\mathbf{I}+\boldsymbol{\Delta}_{\mathbf{W}_{0}}(s)\right), \quad\left\|\boldsymbol{\Delta}_{\mathbf{W}_{0}}(s)\right\|_{\infty}<\gamma,
$$

where $\gamma$ is the uncertainty range. 


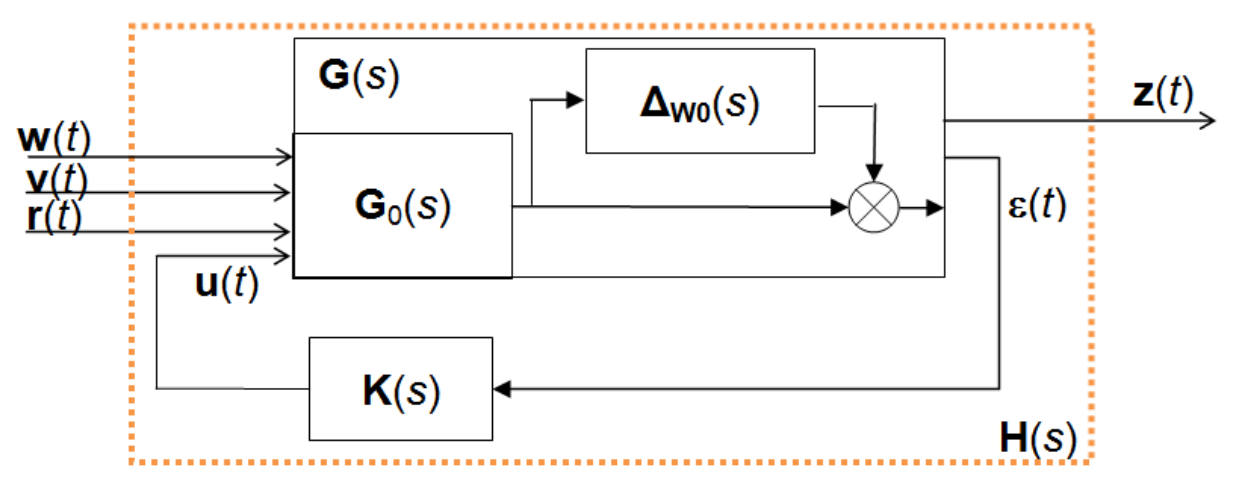

Figure 2. The functional chart of the control system

With regard to the above said, we can formulate the statement of the problem for the robust optimal control of a lamellar pasteurization-cooling unit: for a production object the mathematical model of which in the nominal mode is given by the system (1) with matrices (2), in the category of linear stabilizing controls

$$
\mathbf{u}=\mathbf{K}(s) \boldsymbol{\varepsilon}
$$

to find the optimal control which minimizes the specified quality criterion:

$$
J=\min _{\mathbf{K}(s) \in \Omega}\left\|\mathbf{W}_{L}(s) \mathbf{H}(s) \mathbf{W}_{R}(s)\right\|_{2},
$$

where $\mathbf{H}(s)$ is the transfer function of the closed system, $\Omega$ is the area of stabilizable controls; $\mathbf{W}_{L}(s), \mathbf{W}_{R}(s)$ are weighting matrices according to the outputs and inputs of the system. It is necessary to note that the weighting matrix $\mathbf{W}_{L}(s)$, specifies the quality of the system in the frequency range, and the matrix $\mathbf{W}_{R}(s)$ is a type of an input signal, in particular, one can specify a filter for an inhomogeneous signal spectrum. Thus, using criterion (5), the system minimizes the overall response pulse energy for the deterministic inputs, as well as the square root of the output dispersion for the specified dispersion of the input stochastic signal.

This problem has been solved in the state space for the standard $\mathrm{H}_{2}$ problem [13-15], based on the 2-Riccati approach, with the following weighting matrices:

$$
\begin{gathered}
\mathbf{W}_{L}=\operatorname{diag}\left(\frac{0.1}{50 s+1}, \frac{0.1}{125 s+1}, \frac{s}{500 s+1}, \frac{s}{1000 s+1}, 1,1\right) \\
\mathbf{W}_{R}=\operatorname{diag}\left(\frac{2.5}{2500 s+1}, \frac{1.5}{2000 s+1}, \frac{1}{200 s+1}, \frac{s}{s+0.1}, \frac{s}{s+0.1}, 1,1\right),
\end{gathered}
$$

where $\operatorname{diag}($ ) marks the diagonal matrix, while the linear regulator happens to be of the $11^{\text {th }}$ order. Analyzing the singular values of the transfer matrix of the regulator, it has been concluded that the regulator order can be reduced to the $6^{\text {th }}[16-20]$. The final regulator has 
been chosen and its order has been reduced by the method of balanced reduction according to the criterion:

$$
\left\|\mathbf{K}-\mathbf{K}_{r e d}\right\|_{\infty} \leq 2 \sum_{k+1}^{n} \sigma_{i},
$$

Where $\mathbf{K}(s), \mathbf{K}_{\text {red }}(s)$ are the transfer functions of the output and the reduced regulator respectively, with a marginal error of 0.0335 .

The regulator has been implemented in the range of state variables with the following matrices:

$$
\begin{aligned}
& \mathbf{A}^{K_{\text {red }}}=10^{-2} \cdot\left[\begin{array}{cccccc}
-0.88 & 0.52 & 0.33 & 0.59 & -5.65 & 0.67 \\
-3.51 & -388.41 & -265.61 & -35.26 & -8.09 & -18.69 \\
0.47 & 266.78 & -3.49 & 3.46 & 10.08 & -1.81 \\
0.25 & 52.73 & -6.25 & -1.14 & 28.34 & -2.42 \\
-5.42 & 13.64 & 1.05 & -11.09 & -184.56 & 130.86 \\
-0.39 & 30.69 & -1.60 & -0.24 & -125.39 & -3.48
\end{array}\right] \\
& \mathbf{B}^{K_{\text {red }}}=10^{-2} \cdot\left[\begin{array}{cc}
4.79 & 17.40 \\
149.45 & -4.68 \\
-12.23 & -2.08 \\
-6.10 & -1.54 \\
-0.17 & 60.97 \\
-4.84 & 5.18
\end{array}\right] \\
& \mathbf{C}^{K_{\text {rd }}}=10^{-2} \cdot\left[\begin{array}{cccccc}
18.04 & -2.10 & -4.11 & -6.27 & 60.96 & -6.80 \\
0.29 & 149.50 & 11.70 & 0.57 & 1.50 & 2.02
\end{array}\right], \mathbf{D}^{K_{\text {red }}}=\left[\mathbf{0}_{2 \times 2}\right] .
\end{aligned}
$$

\section{Results of the simulation}

The simulation of a system with a synthesized robust optimal regulator and local PID and PI regulators for a nominal model and a model with maximum multiplicative uncertainty has been conducted. The parameters of local regulators have been synthesized according to the criterion of maximum perturbation filtering. Signals of disturbances have been applied to the system input throughout the time frame, with external disturbances simulated by a stochastic and deterministic component, and at the time of $75 \mathrm{sec}$ the tasks from zero to $2{ }^{\circ} \mathrm{C}$ and $1{ }^{\circ} \mathrm{C}$ have changed respectively. The simulation results are shown in Fig. 3-5 and comparative characteristics are summarized in Table 1. 
Comparative characteristics of systems with $\mathrm{H}_{2}$ - and PID-PI regulators

\begin{tabular}{|c|c|c|}
\hline \multirow{2}{*}{ Characteristics } & \multicolumn{2}{|c|}{ Type of regulator } \\
\hline & $\mathrm{H}_{2}$-regulator & $P I D-P I$ regulators \\
\hline Maximum deviation & $\begin{array}{c}\varepsilon_{1}=2.1{ }^{0} \mathrm{C} \\
\varepsilon_{2}=1.0{ }^{0} \mathrm{C} \\
u_{1}=0.2 \mathrm{~kg} / \mathrm{sec} \\
u_{2}=0.9 \mathrm{~kg} / \mathrm{sec}\end{array}$ & $\begin{array}{c}\varepsilon_{1}=2.0{ }^{0} \mathrm{C} \\
\varepsilon_{2}=1.0{ }^{0} \mathrm{C} \\
u_{1}=1.0 \mathrm{~kg} / \mathrm{sec} \\
u_{2}=1.9 \mathrm{~kg} / \mathrm{sec}\end{array}$ \\
\hline Medium-quadratic deviation & $\begin{array}{c}D \varepsilon_{1}=0.2{ }^{0} \mathrm{C} \\
D \varepsilon_{2}=0.1{ }^{0} \mathrm{C} \\
D u_{1}=0.04 \mathrm{~kg} / \mathrm{sec} \\
D u_{2}=0.1 \mathrm{~kg} / \mathrm{sec}\end{array}$ & $\begin{array}{c}D \varepsilon_{1}=0.4{ }^{0} \mathrm{C} \\
D \varepsilon_{2}=0.1{ }^{0} \mathrm{C} \\
D u_{1}=0.2 \mathrm{~kg} / \mathrm{sec} \\
D u_{2}=0.4 \mathrm{~kg} / \mathrm{sec}\end{array}$ \\
\hline Stability margin & 0.08 & 0.12 \\
\hline$\left\|\mathbf{H}_{\mathbf{w \varepsilon}}(s)\right\|_{2}$ & 0.25 & 0.34 \\
\hline$\left\|\mathbf{H}_{\mathbf{v} \varepsilon}(s)\right\|_{2}$ & 1.02 & 2.25 \\
\hline$\left\|\mathbf{H}_{[\mathbf{w} \mathbf{v}] \varepsilon}(s)\right\|_{\infty}$ & 1.13 & 5.27 \\
\hline$\gamma$ & 0.56 & 0.13 \\
\hline$\|\mathbf{S}(s)\|_{\infty}$ & 1.63 & 5.29 \\
\hline
\end{tabular}

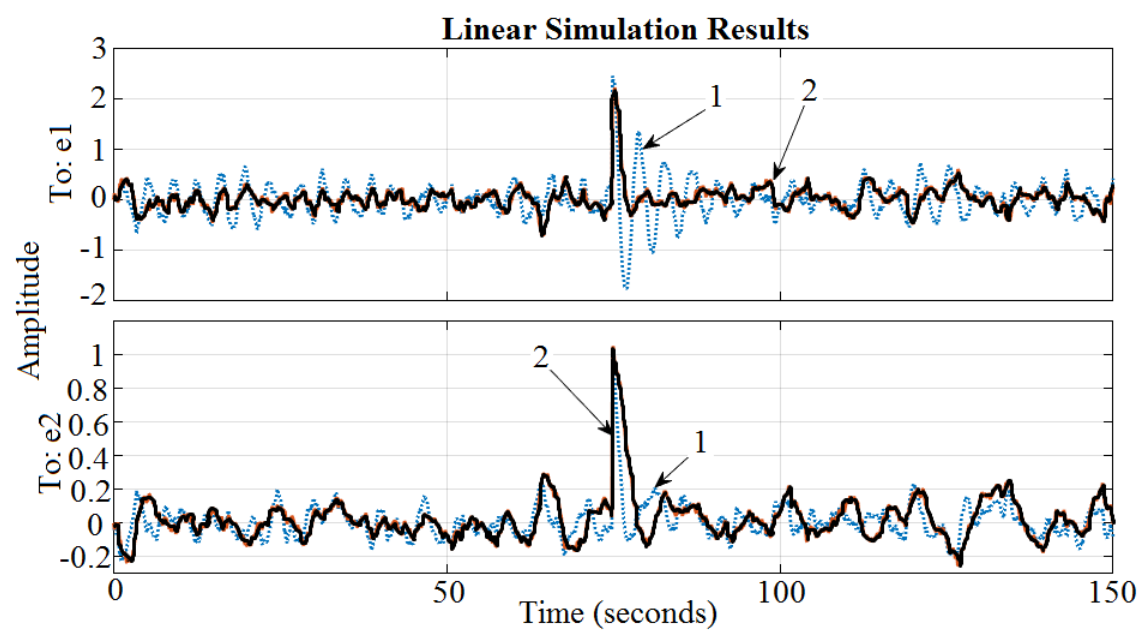

Figure 3. Deviation of pasteurization and cooling temperatures:

1 - System with PID-PI regulators; 2 -System with $\mathrm{H}_{2}$-regulators 


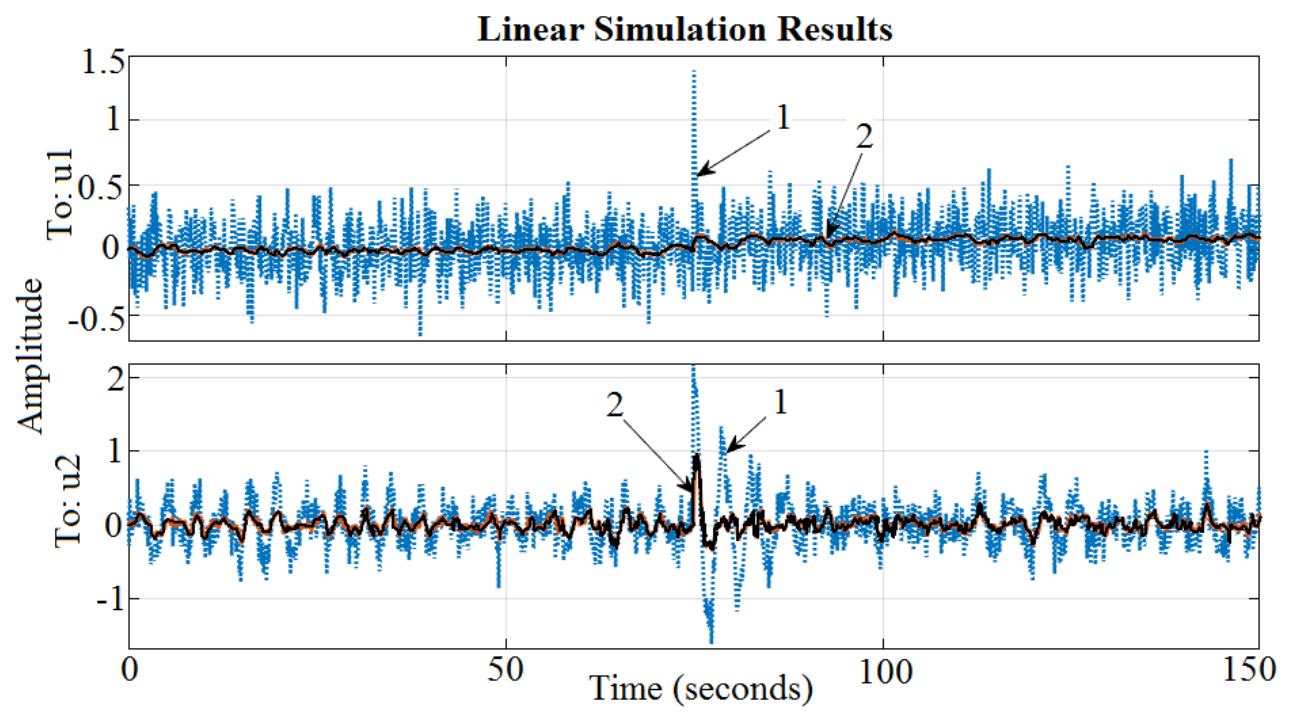

Figure 4. Deviation of control signals:

1 - System with PID-PI regulators; 2 - System with $\mathrm{H}_{2}$-regulators
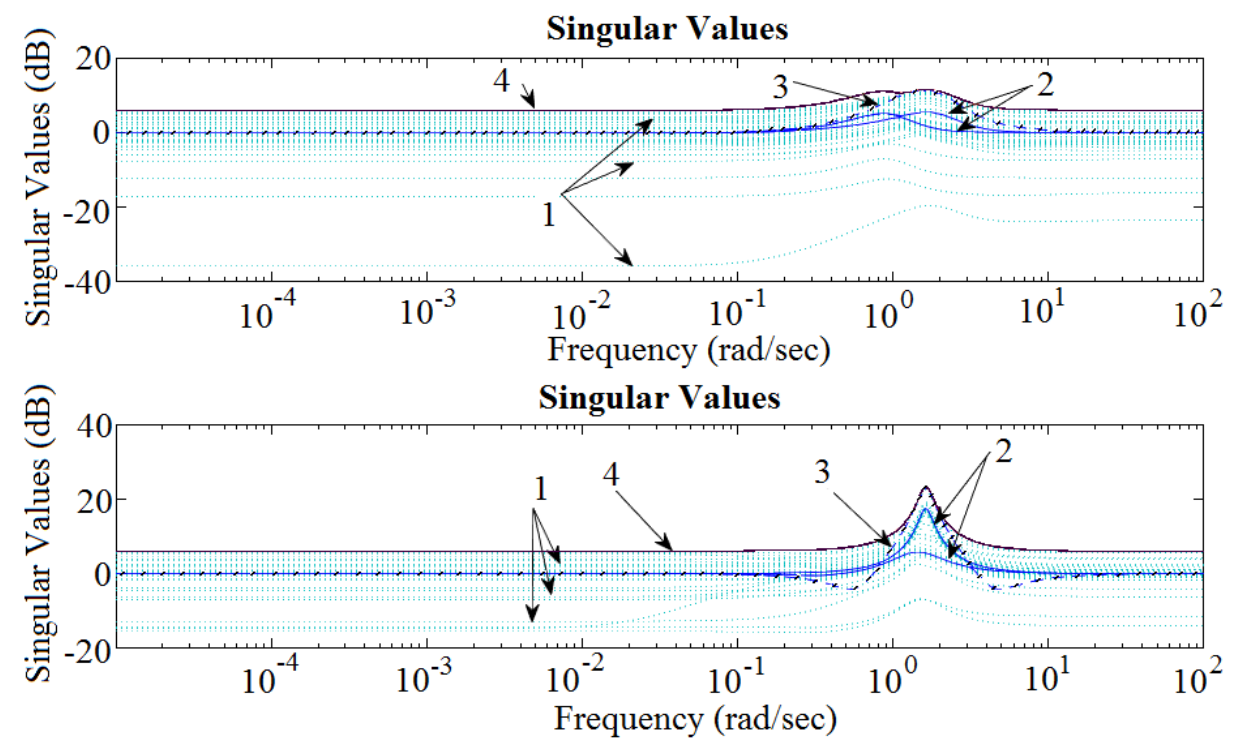

Figure 5. Singular values plot of dynamic system with uncertainty:

1 - System with sampled uncertainty; 2 - Nominal system; 3 - System with worst uncertainty; 4 - Worst-case gain (upper bound) 
The $\mathrm{H}_{2}$-regulator system shows better quality and energy-efficient performance, since the norms characterizing the quality of the system have decreased almost twice, and the scope of uncertainty has increased fourfold. In addition, the $\mathrm{H}_{\infty}$-norms of the sensitivity transfer functions $\mathbf{S}(s)$ for such a system are lower has tripled, which confirms the robust properties of the system. Also, the dispersion of the first regulated quantity was reduced twice, and the dispersion of control signals decreased respectively five and four times. In Fig. 5 is shown graphical worst-case gain analysis [21,22] synthesized system, in particular the curve of upper bound is the envelope produced by finding the highest gain within the uncertainty at each frequency. So, the time and frequency analysis of the system proved the effectiveness of the synthesized control system.

\section{Conclusion}

A lamellar pasteurization-cooling unit performs under the conditions of uncertainty of both the structure and parameters of the object, and intense external perturbations. Advance in efficiency of the control system of lamellar pasteurization-cooling units is possible by constructing a multidimensional optimal regulator in accordance with the $\mathrm{H}_{2}$-norm criterion. The mathematical model of the control object has been presented and reduced to the standard setting of the $\mathrm{H}_{2}$-optimization with the input and output weighting matrices while the synthesized regulator in the space of the state variables has been reduced to the $6^{\text {th }}$ order. The simulation of the system conducted by the $\mathrm{H}_{2}$-regulator has shown its effectiveness compared to the local PID-PI regulators.

Further research is aimed at automatically revealing the conditions for the applicability of robust-optimal regulators for building an information system to support management decisions.

\section{References}

1. Davis J., Edgar T., Porter J., Bernaden J. and M. Sarli (2012), Smart manufacturing, manufacturing intelligence and demand-dynamic performance, Computers \& Chemical Engineering, 47, pp. 145-156.

2. Bhattacharya S.P., Capellat H., Keel L.H. (2000), Robust Control: The Parametric Approach, Prentice Hall PTR.

3. Zhou, Kemin; Doyle C., John (1999), Essentials of Robust Control, Prentice Hall.

4. Morari Manfred; Zafiriou, Evanghelos (1989), Robust Process Control, Prentice Hall.

5. Ricardo S. Sánchez-Peñaand Mario Sznaier (1998), Robust Systems: Theory and Applications, Wiley, NewYork.

6. Ladanyuk A.P., Lutskaya N.N. (2016), Osobennosti zadach robastnogo upravleniia tekhnologicheskimi obieektami. Chast 1. Tekhnologicheskie obieekty i ikh matematicheskie modeli, Problemy upravleniia i informatiki, 5, pp. 16-23.

7. Pintelon R., Schoukens J. (2012), System Identification: A Frequency Domain Approach, Wiley, NewYork.

8. Skeppstedt A., Ljung L., Millnert M. (1992), Construction of composite models from observed data, Int. J. Control, 55(1), pp. 141-152.

9. Ninness B. M. (1993), Stochastic and Deterministic Modeling, University of Newcastle, NSW.

10. Milanese M. and Belforte G. (1982), Estimations theory and uncertainty intervals evaluation in the presence of unkown but bounded errors: Linear families of models and estimators, IEEE Trans. on Automatic Control, 27 pp. 408-414. 
11. Ljung L. (1999), System Identification: Theory for the User, Upper Saddle River.

12. Helmicki A.J. (1991), Control oriented system identification: A worst case / deterministic approach in $\mathrm{h}_{\infty}$, IEEE Transactions on Automatic Control, 36, pp. 11631176.

13. Doyle J.C., Glover K., Khargonekar P., Francis B. (1989), State-space solutions to standard $\mathrm{H}_{2}$ and $\mathrm{H}_{\infty}$ control problems, IEEE Trans. on Automat. Contr., 34 (8), pp. 831-847.

14. Khargonekar P. (1991), State-Space $H_{\infty}$ Control Theory and the LQG Problem, in Mathematical System Theory: the influence of R.E. Kalman, A.C. Antoulas, SpringerVerlag.

15. Glover K. (1984), All Optimal Hankel Norm Approximation of Linear Multivariable Systems, and Their L $\mu$-error Bounds, Int. J. Control, 39(6), pp. 1145-1193.

16. Safonov M.G., Laub A.J., Hartmann G. (1981), Feedback Properties of Multivariable Systems: The Role and Use of the Return Difference Matrix, IEEE Trans. of Automat. Contr., AC-26, pp. 47-65.

17. Safonov M.G., Chiang R.Y. (1989), A Schur Method for Balanced Model Reduction, IEEE Trans. on Automat. Contr., 34(7), pp. 729-733.

18. Safonov M.G., Chiang R.Y., Limebeer D.J.N. (1990), Optimal Hankel Model Reduction for Nonminimal Systems, IEEE Trans. on Automat. Contr., 35(4), pp. 496502 .

19. Zhou K. (1993), Frequency-weighted model reduction with $\mathrm{L}_{\infty}$ error bounds, Syst. Contr. Lett., 21, pp. 115-125.

20. Safonov M.G., Chiang R.Y. (1988), Model Reduction for Robust Control: A Schur Relative Error Method, International J. of Adaptive Control and Signal Processing, 2, pp. 259-272.

21. Blight J.D., Dailey R.L. and Gangsass D. (1994), Practical control law design for aircraft using multivariable techniques, International Journal of Control, 59(1), pp. 93-137.

22. Bates D. and Postlethwaite I. (2002), Robust Multivariable Control of Aerospace Systems, Delft University Press, Delft.

23. Korobiichuk I., Ladanyuk A., Vlasenko L., Zaiets N. (2018), Modern Development technologies and investigation of food production technological complex automated systems, International Conference on Mechatronics Systems and Control Engineering (ICMSCE), Amsterdam, Netherlands, pp. 52-57.

24. Iackymchuk T. (2013), Ukrainian Companies of Food Industry: Investment Activity and Factors Affecting the Results, Economics \& Sociology, 6(2), pp. 82-93, DOI: 10.14254/2071-789X.2013/6-2/8

25. Penchuk A. (2013), Dairy Industry in Ukraine: Evaluation of Business Efficiency, Economics and Sociology, 6(2), pp. 53-64, DOI: 10.14254/2071- 789X.2013/6-2 


\title{
Representation of agricultural producers' interests: substantiation of the research construct
}

\author{
Agota Giedrè Raišienè, Artiom Volkov, \\ Virgilijus Skulskis, Rita Vilkè \\ Lithuanian Institute of Agrarian Economics, Lithuania
}

\section{Keywords:}

Agriculture

Farmers

Participatory

Governance

Article history:

Received

19.06.2018

Received in

revised form

20.08.2018

Accepted

28.09.2018

Corresponding author:

Agota Giedrè

Raišienè

E-mail:

agotagiedre@

gmail.com
DOI:

$10.24263 / 2304-$

974X-2018-7-3-16

\section{Abstract}

Introduction. The research aims to substantiate a construct of the scientific research which enables assess the associated agricultural producers' involvement in agricultural policy-making processes.

Materials and methods. Methods of scientific discourse analysis, survey of agricultural producers, statistical data analysis, systematization and synthesis of scientific insights were used. The theoretical background is based on analysis of management theories explaining a nature of inter-organizational interaction.

Results and discussion. Representation of agricultural producers' interests in policy making processes is inappropriate. We chose Lithuania as example and found that even 85.6 percent of farmers are completely not members of any association or union and only about 10 percent of them participate in activities of organizations of agricultural area. The research results show that in the context of EU financial support for agriculture the problem of stakeholder participation in policy making processes deforms the opportunities of big and small farmers to defend their interests. Participative and Collaborative Governance and concept of partnership and inter-organizational collaboration were achieved i) by distinguishing characteristic groups of associated agricultural producer organizations' participation in agricultural policy making processes, ii) by compiling a scheme of research on the balance of need satisfaction and interest expression of associated agricultural producers, and iii) by forming theory-based battery of interview questions for further qualitative survey was. During analyzing results of research it was found that the implementation of interests based on needs should become a core task for policy makers. In order to do so, it must be ensured that stakeholders' influential power is balanced, and the needs of all interest groups are appropriately evaluated. The research results show that the assumptions for better opportunities to take agricultural stakeholder needs into consideration when forming and implementing agricultural policy could be strengthened.

Conclusions. Research allows systematically gather qualitative data and better substantiates recommendations to politicians and representatives of agricultural producer associations. 


\section{Economics and Management -}

\section{Introduction}

A competitive advantage of organization mostly is influenced by management decisions whereas in agricultural sector the competitiveness is distorted due to the EU support opportunities which essentially are only distributed taking the size of a given farm into consideration $[7 ; 40 ; 41 ; 37]$. Due to this reason, the business and operating conditions of larger-scale farmers are improved quicker than those of smaller ones. Financial support for larger-scale farms allows them to expand, purchase more or more advanced agricultural machinery, implement technological innovations etc. [25; 22; 19].

Furthermore, the differences in farming conditions are influenced by insufficiently justified agricultural policy priorities on a national level in most of post-Soviet countries, and Baltic countries are among them [6;25;37]. The support system in agriculture is formed to support farmers using the same principle without considering their needs, activity opportunities and objective constraints. On the other hand, even though farmers unite into associations and other organized entities, the interests of some of them in the context of agricultural policy are not being protected sufficiently [26].

With the start of a new EU financial period coming near in 2020, the abovementioned issues become especially significant. In addition to that, scientific research on administration effectiveness, business competitiveness and balanced representation of stakeholder interests in making decisions remain important as well $[29 ; 22 ; 7]$. Considering relevance, the aim of the article was defined: on the bases of scientific literature and results of the survey to substantiate a research construct which would enable to assess the associated agricultural producers' involvement in agricultural policy-making processes.

The research developed in later stages would allow the agricultural producers to better protect their interests in pursuing competitiveness in agricultural business and farming. It would also enable the political decision-makers to better understand the nature of stakeholders' needs and differences between them.

\section{Materials and methods}

With the aim to substantiate a research construct which would enable to assess the associated agricultural producers' involvement in agricultural policy-making processes, methods of i) scientific discourse analysis, ii) survey of farmers, iii) statistical analysis of primary data, iv) statistical analysis of secondary data, and v) systematization and synthesis of insights were used. The theoretical background of the article is based on management theories explaining a nature of inter-organizational interaction, and that are: Transaction Costs Economics theory [18; 27; 39], Stakeholders theory [11; 21; 28] and Network theory $[2 ; 3 ; 23 ; 32]$, whereas principles of interest representation and stakeholders' participation in policy making and implementation processes are explained by the concepts of participatory and collaborative governance $[9 ; 20 ; 29]$, also social partnership and interorganizational collaboration ideas $[31 ; 34 ; 17]$ were taken into consideration. Common agricultural policy (CAP) effect on farm development was based on statistical data of Eurostat, and survey of agricultural producers in Lithuania as one of examplar was completed with the aim to reveal context and relevance of the research construct. 


\section{Results and discussion}

\section{Research context: Common agricultural policy effect on farm development in Lithuanian}

The peculiarities of agriculture in Lithuania reduce the agricultural sector's resistance to negative factors both inside and outside the country and sector. These peculiarities were influenced by various conditions, the most significant of which are the implementation of Common Agricultural Policy (CAP) based on the EU support, specifics of national priorities in agriculture and lack of unity between agricultural producers in defending their essential interests.

The criticism on common agricultural policy, especially the imperfectness of direct payment system and its inability to implement the set goals is sore for over a decade [14; $5 ; 40 ; 41 ; 35]$. On one hand, the direct payment system is criticized by the society for spending public funds and constantly facing environmental and animal well-being problems. On the other hand, farmers are dissatisfied with the increasing inequality of income and, in their opinion, unjust distribution of direct payment system elements [22].

Back in 2005-2010, Lithuania was already one of the few EU countries with dominant effect of farm structure polarization, where the number of big farms (over 100 ha) doubled, the number of small farms (under $5 \mathrm{ha}$ ) increased slightly while the number of average farms decreased [25]. This phenomenon indicated an instable agricultural structure, the foundation of which (the average farms) was vulnerable and of low viability.

In 2016, compared to 2005, the number of farms over 100 ha and more in size increased by 114 percent in Lithuania, while in the EU-28 this number was only 11 percent on average (Figure 1). The number of farms of 10 to 100 ha decreased by 32.2 percent in this period while the number increased by 13 percent in the EU. Lastly, the number of farms under 10 ha decreased both in the EU and Lithuania - 33.2 and 44.9 percent decrease respectively. It should be noted that in Lithuania, the number of farms under 10 ha and farms between 10 and 100 ha decreased twice as quickly as in rest of the EU.

According to Lithuanian agricultural structure, in 2016 there were 107.8 thousand farms under 10ha. The number of farms over 100 ha was only 5.3 thousand, however, their owners owned almost 3.5 times more area by hectares. In other words, currently in Lithuania, 3.5 percent of landowners control more than 50 percent of all agricultural land utilities.

The changes in Lithuanian agricultural structure became clear after implementing the direct payment system and applying a one-time payment-for-area scheme [25]. A support system based on payments for owned agricultural land utility area in hectares had a strong influence on the changes in types of production generated in farms. Farmers significantly increased investment into grain growing as an activity that requires big areas of land. This allowed to ensure direct financial returns through direct payments with relatively low work and capital input requirements per 1 ha of land [37]. The consequences of decision to grow more grain are especially visible comparing years 2005 and 2016. In 2016, Lithuania became a leader in the change of grain growing farms amongst all EU member countries. In this time period, the number of grain growing farms in Lithuania increased by 346 percent while the growth in the EU was only 7 percent on average. It should be emphasized that the area of arable land used in farms increased as well - an increase of 186 percent is observed. 

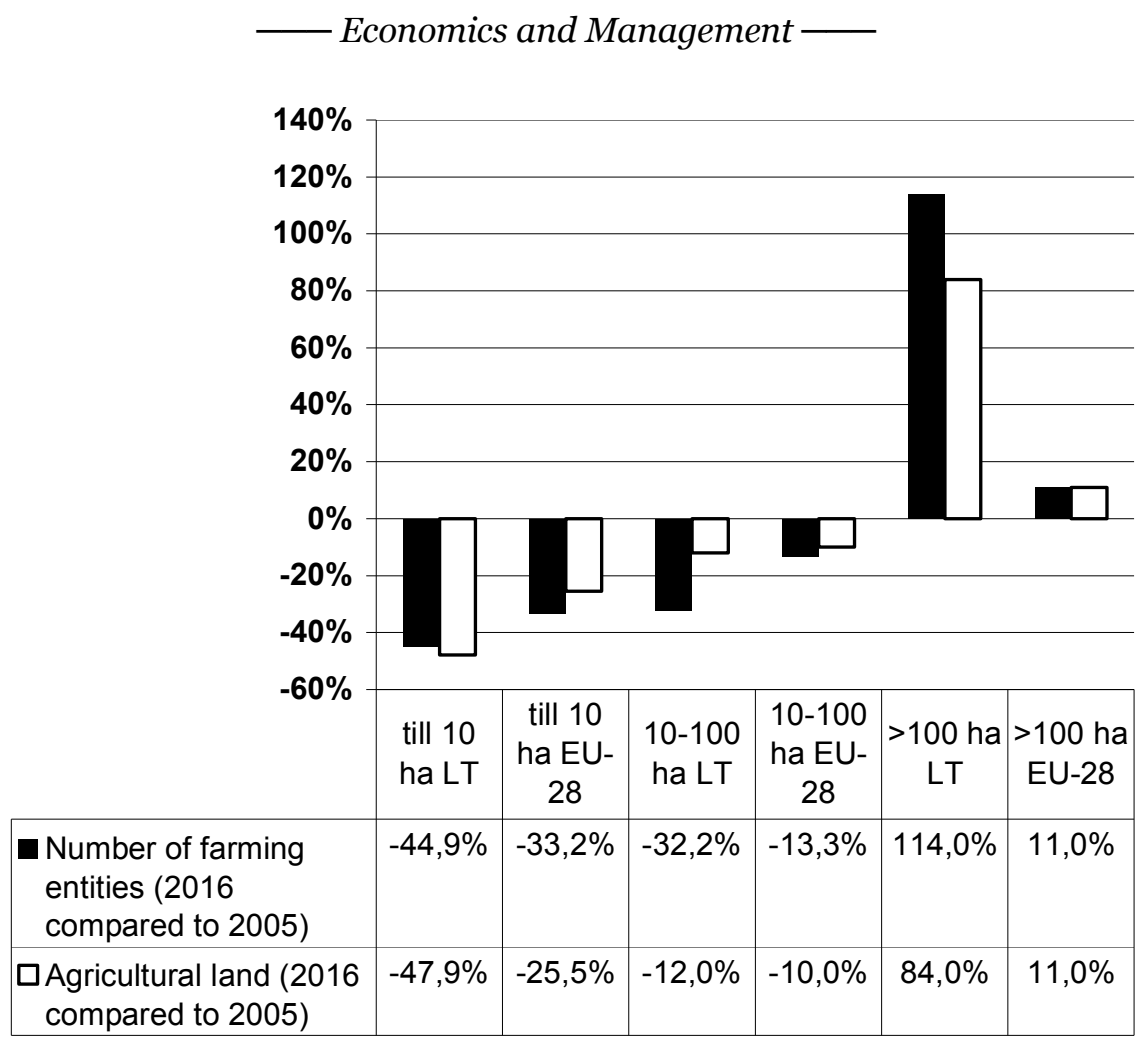

Figure 1. The change in the number of farms and farmland in different groups by size in Lithuania and on average in EU-28, 2016 compared to 2005. Source: authors compilation based on EUROSTAT.

The support measures of common agricultural policy had an influence on Lithuanian agricultural structure changes too. Some national level rules of financial support for agriculture made it easier for larger-scale farms, especially those over 100 ha to receive bigger support. Due to production potential being directly proportional to farm size, big farmers became more attractive to financial credit companies while the owners of small farms were assigned a higher risk group and lost a part of opportunities to acquire or develop their competitive advantage by investing into new activities or development.

Summing it up, the abovementioned reasons and conditions in Lithuania caused: i) agricultural structure changes and decrease in farm numbers; ii) vulnerability of farms growing other production than grain; iii) competitive imbalance between farms considering both size and production type; iv) contraposition of small and big farmers; v) more evident display of social inequality; vi) imbalance of agricultural producers' interest representation in agricultural policy making observed through political decisions that insufficiently satisfy the needs and interests of small farmers. However, in order to objectively evaluate if and how the size of the farm is related to the representation of interests of its owner in agricultural policy making and to provide recommendations which would allow to ensure adequate satisfaction of agricultural producers' needs, a definition of small, average and big farms has to be formed. 


\section{Economics and Management -}

The area of the farm is one of the most commonly used criteria in statistical, economic and political analyses which determine the boundaries between small and other farms. Small farms are defined differently in different countries: fewer than 2 ha, under 5 ha, under 10 ha of land utilities or 10 percent of smallest farms that declare land utilities [6;19; 10]. Thus, if an agreement was made in Lithuania on what criteria would allow to unambiguously classify farms by their size, it would be possible to more clearly evaluate the potency of farmer group interest representation and to pursue a common societal wellbeing by executing a more effective and favorable agricultural policy.

\section{Relevance of agricultural producers' interests representation research}

A survey of agricultural producers was carried out to determine the relevance of scientific research problem. An original representative empirical data were collected by experienced research subcontractor. Population of Lithuanian farmers equals to $\mathrm{N}=138.9$ thousand. Calculated representative population under statistical conditions of 3 percent error $(\varepsilon=0.05)$ and 95 percent $(p=0.5)$ confidence level is $n=1059$. Respondents were selected using systemic sampling of research subcontractors' database. Data were collected using telephone interviews of Lithuanian farmers in January-February 2017. Potential respondents had been telephoned 3211 times, 1491 times without response, 612 farmers rejected the suggestion to take part in the interview. Finally, 1108 interviews were found suitable for further investigations which satisfy defined statistical conditions.

The obtained data was processed with descriptive statistical analysis. The percentage distribution of respondents' answers was calculated, comparing data between the groups by using $\chi^{2}$ test (significance level $p<0.05$ ). The sample size of the study allows ensuring that the statistical error of the results does not exceed 3.1 percent. Statistical analysis of data was performed using the SPSS 20.0 program. A two-stage variable $\chi^{2}$ independence test was performed to determine whether the respondent's characteristics (sex, age, etc.) affect the distribution of answers to questions. Only those answers are used as evidence, in which the test showed that the distribution of answers depends on the respondents' characteristics.

The study involved 57.7 percent men and 42.3 percent women. The majority of surveyed farmers ( 38.3 percent) were respondents aged from 55 to 64 ; the second age group (27.6 percent) was farmers aged between 45 and 54, respondents of 65 years and older composed 23.9 percent. The smallest group of respondents is represented by youngest farmers: 1.1 percent is up to 35 years and 9.1 percent aged between 35 and 44 . The majority of respondents ( 34.5 percent) had acquired professional education; farmers with acquired upper and secondary education composed respectively 23.7 percent and 21.4 percent. The smallest group of respondents according to their education consists of respondents with lower secondary ( 4.6 percent) and primary education (1.6 percent). The majority ( 88.4 percent) of the surveyed farmers acquired education before 1990 (or in the Soviet period), 10 percent - before the Lithuania's accession to the EU (i.e. in the period of 1990-2004) and 1.6 percent in 2005 or later, i.e. after Lithuania's accession to the EU.

The majority of respondents ( 44.8 percent) are farmers whose farm size is up to 20 hectares (ha); 32.1 percent - from 20.1 to 50 ha; 13.7 percent - from 50.1 to 100 ha. The smallest part of the respondents are farmers with farms of 100.1 to 500 ha (9.2 percent) and more than 500.1 ha $(0.2$ percent).

According to the criterion of the duration of the activity, almost half of the surveyed farmers (46.6 percent) started their farming activities 21 year ago or even earlier, a similar proportion of respondents (43.1 percent) - from 11 to 20 years ago, and the youngest farms with experience 10 and less years of farming composed 10.3 percent. More than half of the 
respondents (54.1 percent) have mixed (both crop and livestock) farms, 21.5 percent are crop farmers, and livestock farmers compose 13.3 percent.

By summarizing the general statistical characteristics of the survey, it can be stated that given data is representative.

Talking about research insights, it should be emphasized that representation of agricultural producers' interests in is inappropriate. Even 85.6 percent of farmers are not members of any organization (e.g. association, union, confederation, etc.) and only about 10 percent of farmers participate in activities of organizations of their professional area (Figure 2).

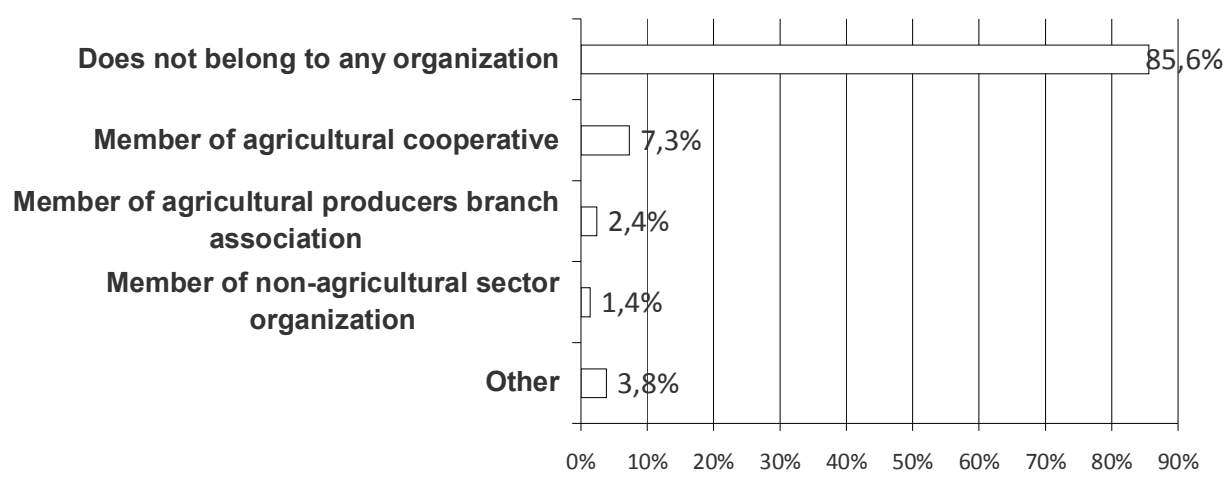

Figure 2. Agricultural producers' participation in organized activities.

Source: authors.

A similar portion of farmers shows personal initiative to cooperate having an aim to protect common interests (Table 1).

On the other hand, 53.8 percent of respondents are ready to contribute in case of joint activity were organized in their community or rural area, or area of their professional expertise (Figure 3).

Table 1

Distribution of answers to the question "Have you ever asked other farmers to cooperate with the aim to protect common interests?"

\begin{tabular}{|l|c|c|}
\hline & Frequency & Percent \\
\hline Yes & 147 & $\mathbf{1 3 , 3}$ \\
\hline No & 958 & $\mathbf{8 6 , 4}$ \\
\hline Other & 3 & 0,3 \\
\hline Total & 1108 & 100 \\
\hline
\end{tabular}

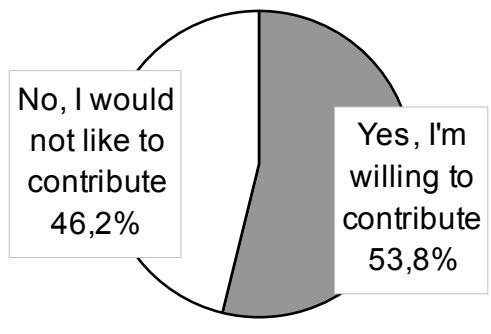

Source: authors.

Figure 3. Farmers' willingness to contribute in joint activity.

Source: authors. 


\section{- Economics and Management -}

The contradiction between attitudes and behavior of farmers can lead to a question of what determines the situation that farmers do not enter organizations for joint activities although they have willingness for this. In order to answer this question, qualitative research construct is modeled and presented further.

\section{Construct of research on representation of associated agricultural producers ${ }^{6}$ interests: theoretical background}

The plan of the research on associated agricultural producers' opportunities to satisfy the needs of represented farmers was based on a theoretical basis which would allow to explain the relationship between the society, country and business and would allow to understand what principles and assumptions should be followed to coordinate the goals of all sides.

Management theory analysis has allowed to distinguish three theories complying with this goal: Transaction Costs Economics theory, Stakeholders theory and Network theory, whereas principles of interest representation and stakeholders' participation in policy making and implementation processes are explained by the concepts of participatory and collaborative governance.

In this context, social partnership and interorganizational collaboration ideas were taken into consideration. They allowed to emphasize the essential goal and principle assumptions of joint actions of all stakeholders.

Transaction Costs Economics theory. Transactions costs economics theory (TCE) is based on specific assumptions. The first assumption states that an individual's behavior is opportunistic, and "self-interest is unconstrained by morality" [27]. The second assumption regards the requirement for success. Here, "efficiency" within predefined rules of the game is the criterion that determines the desirability of the outcome [39]. However, actors will not behave opportunistically by all means. The probability of opportunism occurring increases as asset specificity increases [18]. „Opportunism occurs when outcomes are highly uncertain, reputation is difficult to establish, and the payoff from opportunism in the present period outweighs the discounted present value of future cooperation" [18]. On the other hand, organizations have the ability to reduce opportunism through hierarchical control [15]. Thus, collaborative activities between the transaction parties are of major importance to the economic results the organization achieves. However, positive results are not always achieved. For example, when the number of interacting sides with influential power is low, competition occurs. It is especially relevant in the context of associated agricultural producer organizations and their influence on country-level decisions on agricultural sector. Ensuring that all stakeholders directly related to the decision are able to adequately participate in decision making processes becomes a crucial factor.

Stakeholder Theory. The Stakeholder Theory (SHT) connects the economic and social aspects of an organization and allows explaining the nature of relationships important to the existence of the organization [11]. According to SHT, the interests of all stakeholders are important, thus there should be no dominant interests [21]. An organization which takes into consideration the interests of all stakeholders sooner or later wins the competitive battle against an organization which only considers limited interests or bestows privilege on a particular interest group [8]. On an interorganizational level, SHT allows to solve the problem of organizational relations and interaction. The selection and inclusion of associated stakeholders should depend on the relevant issue and tasks being solved by the 
organization in given circumstances. With this goal in mind, Mitchell et al. offer to determine to what extent the stakeholders are significant in the organization, evaluating three attributes of organizational relations: 1) power to influence the organization, 2) legitimacy of the relationship between organization and the stakeholder and 3) urgency of reacting to stakeholders' demands [28]. Stakeholders that correspond with only one attribute are called latent; those that correspond with two attributes are called expectant while those that correspond with all the attributes are called definitive stakeholders. It is also possible that a group or organization does not correspond with any of the attributes, in which case they are considered potential stakeholders. It should be noted that power, legitimacy and urgency can change depending on circumstances. Due to this reason, attributes may be gained or lost [28]. Thus, the significance of a stakeholder should be evaluated every time taking into consideration both changes and reality. Moreover, stakeholders can be external and internal, part of which can have overlapping interests. This way, different stakeholders may have different opportunities for creating mutual benefit in the stakeholder relationship [30].

Frooman refills SHT by claiming that stakeholders tent to influence organization management and decision making: "The appropriateness of a stakeholder's claim may not matter nearly as much as the ability of the stakeholder to affect the direction of the firm." [12, p. 193]. Therefore, such characteristics of interaction as participation basis and relationship structure should be taken into account for stakeholder analysis and mapping. A proper understanding of stakeholders' interests and power is crucial for efficiency of organization management.

The contribution of SHT should be exclusively mentioned when speaking about public sector organizations. In this case, the term "stakeholders" covers the whole society or especially large parts of it. Stakeholder engagement in solving issues of societal well-being can therefore manifest through direct participation in activities of non-governmental organizations, government bodies etc. (e. g. decision making) or indirect participation incorporating significant actors into stakeholder networks.

Network theory. Representatives of political science and sociology employ the metaphor of network for explanation of political decision-making processes [32]. Network is a dynamic structure involving entities in different volumes and intensities. Networked organizations create a system of dependent variables without having a permanent organizational structure [2].

Concept of network theory was based by Kickert et al. [23], while Agranof and McGuire [3] processed the acquired empirical data and suggested a model of public network management. The network theory states that the performance of an organization is not based on hierarchical structures only, but on interaction between the components of the network. Therefore, network theory emphasizes the importance of facilitation, which is much more important in public sector. Facilitators must foster the members of the network, organize joint meetings and act as mediators in disputes; also, they must avoid supporting suggestions of particular interest groups and making one-man decisions [23]. The success of network structures is largely determined by the executives of organizations who should assume the function of a network conductor which is to create, manage and employ vertical as well as horizontal linkages among stakeholders [3].

The difference between Network theory and SHT and TCE is that it discusses subject relations, their directions and characteristics of the whole network rather than the interaction between actors and their influence on one another. 
The principle assumptions of all three theories are widely reflected in participatory and collaborative governance concepts which are important to consider to reasonably examine the issue of stakeholder participation in policy making processes.

Concepts of participatory and collaborative governance. Collaborative governance is defined as a structure and process of public policy decision making that involves various stakeholders to carry out a public purpose. Meanwhile, participatory governance is considered as involvement of public, private profit and NGO actors who are not normally concerned with decision making [9;29]. While participatory government is more focused on questions on government counseling with stakeholders, collaborative governance emphasizes the process of working together in particular. Both conceptions speak about participation and collaboration in making policy decisions and assessment of social impact. However, both of them have attributes characteristic only to one or another. According to Huxham, „collaboration carries ideological connotations associated with participation and empowerment. [...] Participation generally means engagement of stakeholders in the decision-making processes that affect them.“ [20, p. 340].

Concepts of collaborative and participatory governance deals with stakeholder inclusion into decision making processes as a way to increase the social and economic efficiency of the formed policy [4].

In order to implement collaborative governance conception in practice, it should be accepted that public interest and overcoming society's problems is of highest importance. In reality, it is complicated because interest groups compete with one another on a political level. It is hard for interest groups to give up on adversarialism and corporatism just like it is hard for the government to give up on managerialism [13].

Successful collaboration between stakeholders and the government depends on engagement of key stakeholders because weak engagement of stakeholders undermines the legitimacy of collaborative outcomes. Based on scientific research, authors state that exclusion of stakeholders can lead to situation where alternative forum will be formed [4]. Thus, it makes sense that the results of collaboration become distorted while the decisions that solve social and economic problems and due to which intersectoral collaboration takes place are usually inefficient.

Therefore, it is extremely important to find a way to ensure a balanced stakeholder participation in policy making in every case.

General provisions of inter-organizational interaction. The main value of partnership and inter-organizational collaboration is the effect of manifold synergy between actors, the goal they seek and processes they perform. Partnership is intended to implement social, economic and political programs and to solve problems common to stakeholders while collaboration is mainly characterized by the time given for joint work, especially to reach high level of trust and joint resources, from material to intellectual [31].

In social partnership, joint activity of organizations functioning in different sectors is of the highest value [34]; the competitive advantage is gained when neither partner can be changed or eliminated due to its unique position [33]. Partners that share common interests and joint goal rise to the next level of integration, the so called inter-organizational collaboration. As collaboration is a voluntary commitment in its nature, joint action requires stakeholders' commitment to behave on a non-competitive basis [17]. As a result, the live involvement of actors from organizations participating in joint activities, equal status in decision-making, efficiency of internal communication and continuous and 


\section{Economics and Management -}

reciprocal informative relations with a target group are of highest importance in collaboration $[38 ; 16]$.

The more intensively the organizations are involved into joint activities, the closer relations between them are formed and the higher joint results can be expected [36]. The process of implementation of partnerships and collaboration is full of difficulties. Many partnerships collapse due to bad understanding, incorrect allocation of costs and benefits, and distrust [1]. Thus, the principle assumptions of partnership and collaboration formed by scientists and verified by practitioners should be referred to by stakeholders with joint or overlapping goals.

\section{Methodological substantiation of the research construct}

The qualitative research methodological construct is based on analysis of beforementioned theories. It allows to identify the characteristics of associated agricultural producers' participation in agriculture policy making processes through economic benefit, engagement and commitment, influential power, nature of reciprocal relations and potential and constraints of collaboration (Figure 4.)

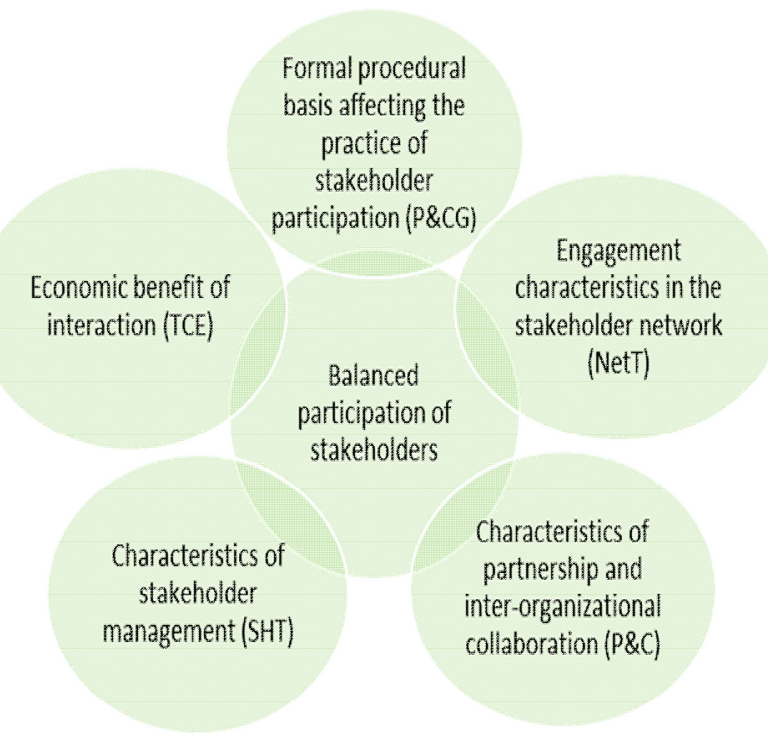

Figure 4. Groups of characteristics of associated agricultural producer organizations'
participation in agricultural policy making processes. Source: authors.

The distinguished characteristics of associated agricultural producer groups form a basis to study the specifics of such producers' participation in agricultural policy making and to prepare detailed instrumentation for research on the balance of the satisfaction of their needs and expression of interests. The instrumentation is schematically depicted in Figure 5.

The hypotheses of the research could be verified by a quantitative research. However, it is not the goal of this article and the instrumentation for quantitative research is not discussed further in the article. 


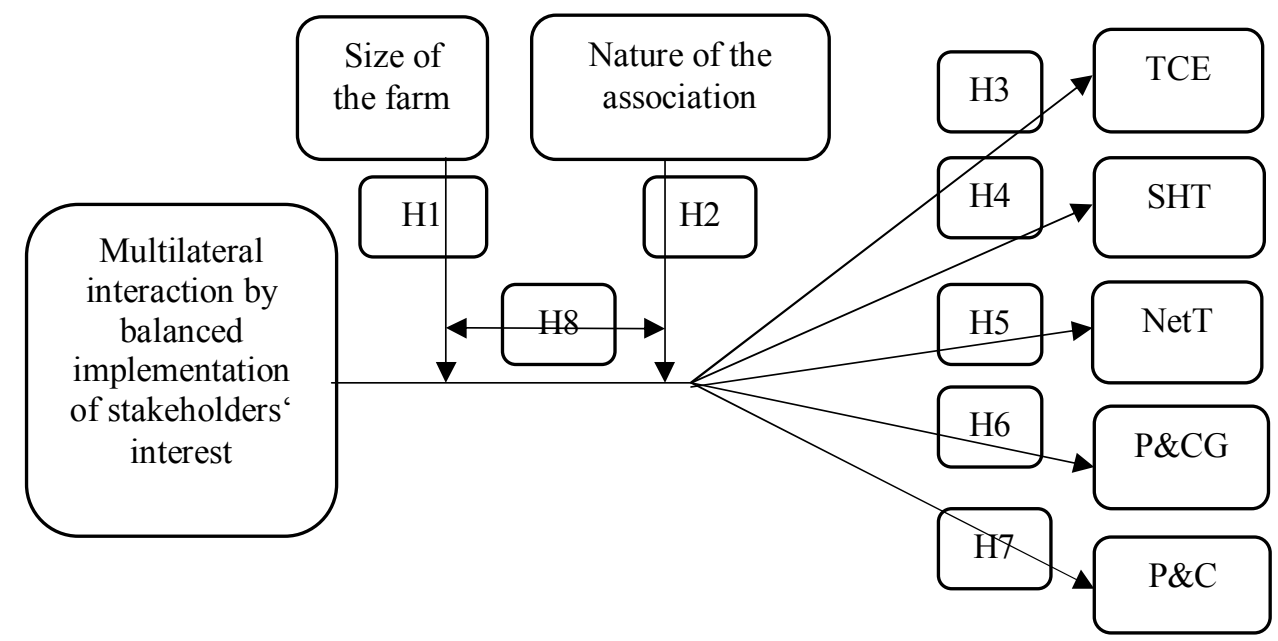

Figure 5. The scheme of research on the balance of associated agricultural producers' need satisfaction and interest expression.

Source: authors.

In order to determine what opportunities associated agricultural producer organizations have to express the needs and interests of their represented members, an expert, semistructured interview of farmer association leaders would be valuable. The interview would be carried out in a homogenous sample because all agricultural producer organizations in Lithuania and the EU have equal legal opportunities to participate in the policy making and implementation processes while the leaders of associations can take on the initiative in intersectoral activities in order to better meet the farmers' needs.

The interview questions were shaped on theoretical approaches discussed in the section above. Theory-based battery of research questions are shown at a Table 2.

Table 2

A construct of an interview: theory-based battery of research questions

Q1 - Transaction Costs Economics theory (TCE):

What economic benefit the associations achieve both separately and together and what benefit could they expect from participating in policy making processes?

$$
\text { Q2 - Stakeholder Theory (SHT): }
$$

How are the farmers' needs and expectations, and association's interests taken into account when forming agricultural policy at the State level?

Q3 - Network Theory:

How organized and enabling is the structure of associated agricultural producer network?

Q4 - Concepts of Participative and Collaborative Governance (P\&CG):

What structures and processes ensure the engagement of stakeholders of different sector, activity, volume and skills in the agricultural policy making processes?

$$
\text { Q5 - Partnership and inter-organizational collaboration (P\&C): }
$$

How satisfied are the agricultural producers with their reciprocal partnership and interorganizational and interinstitutional collaboration results and process?

Source: authors. 
The interview is designed to collect qualitative data required to better understand the problem context of agricultural producers' expression of interest.

The questions of Q1 group are meant to receive information about how the representatives of associated agricultural producers evaluate the opportunity to express the economic needs and interests of members they represent; if they have a possibility to initialize decisions based on needs and interests and propose decision corrections; if they collaborate with other associated agrarian organizations etc.

The questions of Q2 group help to find out if the needs expressed by agricultural producers and their associated organizations are held equally important in making agricultural policy decisions; how dominant interests are balanced out; how less active associated organizations of agricultural producers are included etc.

Q3 group's questions are meant to determine the existing relation structure by the power to influence agricultural policy decisions on a state level; how interorganizational and interinstitutional meetings between associated agricultural producer organizations are organized; what the essential characteristics of interorganizational relations in the agricultural producer representatives network are etc.

Q4 group's questions help to ascertain the principles of stakeholder engagement the governmental institutions follow and to determine if this procedure allows to ensure a balanced expression of interests as well as to find out what problems are solved by joint work between groups or institutions etc.

Questions of Q5 group are designed to receive information on the level of trust between agricultural producer organizations; what synergy stakeholder cooperation creates; what prevents joining intellectual, material and other resources to achieve both agricultural policy decisions that satisfy needs and interests and efficiency and effectiveness of activity etc.

Semi-structure interview provides the researcher with the opportunity to shift the conversation to relevant questions, ask additional questions or clarifications. Therefore, this interview should not be taken as an instruction but rather guidelines that facilitate the researchers' work and allow to maintain the theoretical methodological integrity of the research.

\section{Conclusions}

The analysis of scientific literature allows to state that a scientific and practical problem of stakeholder participation in policy making processes exists. In the context of the common agricultural policy of the EU and particularly in the context of EU financial support for agriculture, this problem is faced by a wide circle of stakeholders and becomes especially sore because it deforms the opportunities of big and small farmers to defend their interests.

In order to solve this problem, the article forms a theoretically and methodologically substantiated construct of associated agricultural stakeholder organizations ' influential power and participation in agricultural policy making. Based on the Transaction Costs Economics theory, Stakeholder Theory, Network Theory as well as the concept of Participative and Collaborative Governance and concept of partnership and interorganizational collaboration, the following were achieved:

a. Characteristic groups of associated agricultural producer organizations ‘ participation in agricultural policy making processes were distinguished;

b. A scheme of research on the balance of need satisfaction and interest expression of associated agricultural producers was compiled; 
c. A theory-based battery of interview questions for further research of stakeholder in agriculture was formed.

Research proposed in the article could strengthen the assumptions for better opportunities to take agricultural stakeholder needs into consideration when forming and implementing agricultural policy. It should be emphasized that the implementation of interests based on needs, not wishes, principles or intent should become a core task for policy makers. In order to do so, it must be ensured that stakeholders' influential power is balanced, and the needs of all interest groups are appropriately evaluated.

Research on representation of agricultural producers' interests, conducted based on the theoretical and methodological construct of the research would allow to systematically gather qualitative data and better substantiate recommendations to politicians and representatives of agricultural producer associations who seek to more efficiently engage and participate in agricultural politics.

\section{References}

1. Afsarmanesh M., Camarinha-Matos L., Soares A.L. (Eds.) (2016), Collaboration in a Hyperconnected World. 17th IFIP WG 5.5 Working Conference on Virtual Enterprises, PRO-VE 2016, Porto, Portugal, October 3-5, 2016, Proceedings, Springer.

2. Agranoff R., McGuire M. (2001), After Network Is Formed: Process, Power and Performance, In Mandel (ed.) Getting Results through Collaboration: Networks and Network Structures for Public Policy and Management, Quorum Books.

3. Agranoff R., McGuire M. (2003), Inside the Matrix: Integrating the Paradigms of Intergovernmental and Networking Management, International Journal of Public Administration, 26(12), pp. 1401-1422.

4. Ansell Ch., Gash A. (2007), Collaborative Governance in Theory and Practice, Journal of Public Administration Research and Theory, 18, pp. 548-571.

5. Bureau, J.C., Mahé L.P. (2008), CAP Reform Beyond 2013: An Idea for a Longer View. http://www.notre-europe.eu/uploads/tx_publication/Etude64-CAP-Propositions-EN_01.pdf

6. Csaki C., Forgacs C. (2009), Small Farms in Central and Eastern Europe: Is There a Future for Them? University of Kent, Canterbury, UK.

7. European Commission (2017), Direct Payments, Single Area Payment Scheme and Transitional National Aid.

8. Donaldson T., Preston L.E. (1995), The stakeholder theory of the corporation: concepts, evidence, and implications. Academy of Management Review, 20(1), pp. 65-91.

9. Emerson K., Nabatchi T. (2015), Collaborative Governance Regimes. Washington, DC: Georgetown University Press.

10. European Commission (2011), EU Agricultural Economic Briefs. What is a small farm? Brief, 2.

11. Freeman R.E. (1999), Response: divergent stakeholder theory, Academy of Management Review, 24(2), pp. 233-236.

12. Frooman J. (1999), Stakeholder influence strategies, Academy of Management Review, 24(2), pp. 191-205.

13. Futrel R. (2003), Technical advertarialism and participatory collaboration in the U.S. chemical weapons disposal program, Science, Technology and Human Values, 28, pp. 451-482.

14. Gay S. H., Osterburg B., Baldock D., \& Zdanowicz A. (2005), Recent evolution of the EU Common Agricultural Policy (CAP): state of play and environmental potential. MEACAP WP6, D4b, Federal Agricultural Research Centre, Braunschweig and Institute for European Environmental Policy, London.

15. Ghoshal S., Moran P. (1996), Bad for Practice: A Critique of the Transaction Cost Theory, The Academy of Management Review, 21(1), pp. 13-47.

16. Gray B. (1985), Conditions facilitating interorganisational collaboration. Human Relations, 39(10), pp. 911-936. 
17. Henneman E.A., Lee J.L., Cohen J.I. (1995), Collaboration: concept analysis. Journal of Advanced Nursing, 21, pp. 103-109.

18. Hill C.W.L. (1990), Cooperation, Opportunism, and the Invisible Hand: Implications for Transaction Cost Theory, The Academy of Management Review, 15(3), pp. 500-513.

19. Hubbard C. (2009), Small farms in the EU: How Small is Small? University of Kent, Canterbury, UK.

20. Huxham C.H. (2000), The challenge of collaborative governance, Public Management, 2(3), pp. $337-357$.

21. Jones T.M., Wicks A.C. (1999), Convergent stakeholder theory, Academy of management review, 24(2), pp. 206-221.

22. Katsarova I. (2013), Common Agricultural Policy after 2013. What will change, Library of the European Parliament-Library Briefing.

23. Kickert W.J., Klijn E.H., Koppenjan J. (1997), Managing Complex Networks: Strategies for the Public Sector, Sage Publications, London.

24. Le Ber, M.J., Branzei, O. (2010), (Re)Forming Strategic Cross-Sector Partnerships: Relational Processes of Social Innovation, Business \& Society, 49(1), pp. 140-172.

25. Melnikienè R., Volkov A. (2013), Impact of the CAP support measures on the agricultural sector in Lithuania, Economic, social and institutional factors in the growth of agri-food sector in Europe, Multi-Annual programme 2011-2014, 67(1), pp. 112-127.

26. Milašius A. (2018), Ükininkai suskilo - kuria alternatyva Žemés ūkio rūmams. Accessed (23-072018) on https://www.delfi.lt/agro/agroverslo-naujienos/ukininkai-suskilo-kuria-alternatyvazemes-ukio-rumams.d?id=77797353

27. Milgrom P.R., Roberts I. (1992), Economics, orgranization and management. Englewood Cliffs, NJ: Prentice Hall.

28. Mitchell R.K., Agle B.R. \& Wood D.J. (1997), Toward a theory of stakeholder identification and salience: defining the principle of who and what really counts, Academy of Management Review, 22(4), pp. 853-886.

29. Newig J., Challies E., Jager N.W., Kochskaemper E., Adzersen A. (2017), The Environmental Performance of Participatory and Collaborative Governance: A Framework of Causal Mechanisms, Policy Studies Journal, pp. 1-29.

30. Post J.E., Preston L.E., Sachs S. (2002), Managing the extended enterprise: the new stakeholder view, California management review, 45(1), pp. 6-28.

31. Raisiene A.G. (2009), In Quest of Integrated Collaboration, LAP LAMBERT Academic Publishing AG \& Co. KG, Saarbrucken.

32. Rethemeyer K.R. (2005), Conceptualising and Measuring Collaborative Networks, Public Administration Review, 65 (1), pp. 117-121.

33. Samii R., Van Wassenhove L.N., Bhattacharya S. (2002), An Innovative Public-Private Partnership: New Approach to Development, World Development, 30 (6), pp. 991-1008.

34. Seitanidi M.M., Koufopoulos D.N., Palmer P. (2010), Partnership Formation for Change: Indicators for Transformative Potential in Cross Sector Social Partnerships, Journal of Business Ethics, 94, pp. 139-161.

35. Swinnen, J. (Ed.) (2010), The Political Economy of the Most Radical Reform of the Common Agricultural Policy, Centre for European Policy Studies.

36. Torres G.W., Margolin F.S. (2003), The Collaboration Primer. Proven Strategies, Considerations and Tools to Get Your Started, HRET, pp. 20.

37. Vidickienė D.; Melnikienè R. (2014), Kaimo politikos evoliucija, Lietuvos agrarinès ekonomikos institutas, pp. 272.

38. Vigoda-Gadot E. (2004), The case for collaboration: A road map based on the Carmelite project in Israel and some lessons for revitalizing democracies, Public Administration and Management Journal, 9(1), pp. 1-14.

39. Williamson O.E. (1991a), Strategizing, economizing, and economic organization, Strategic Management Journal, 12, pp. 75-94.

40. Zahrnt V. (2009a), Public money for public goods: winners and losers from CAP reform, European Centre for International Political Economy, pp. 1-37.

41. Zahrnt V. (2009b), The Budgetary Aspects of The New CAP Payments: note, Policy Department B: Structural and Cohesion Policies. 


\section{Анотації}

\section{Харчові технології}

\section{Вплив метилжасмонату, саліцилової кислоти та аскорбінової кислоти на якісні показники полуничних плодів (Fragaria x ananassa Duch) під час холодного зберігання}

Мераб Ягенті, Леван Гулуа, Тамара Турманідзе Аграрний університет Грузії, Тбілісі, Грузія

Вступ. Проведені дослідженян з метою вивчення комбінованого ефекту розчину метилжасмонату, саліцилової кислоти та аскорбінової кислоти на зберігання полуничних плодів.

Матеріали та методи. Антоціани кількісно визначені $\mathrm{pH}$-диференційованим методом. Загальні фенольні сполуки визначали за допомогою реагенту ФолінаЦикальте. Аналіз FRAP (відновлення флюоресценції після фотознебарвлення) застосовували для визначення антиоксидантної активності. Визначення окремих антоціанів проводили за допомогою високоефективної рідинної хроматографії (HPLC) із використанням рідинного хроматографа марки Varian-Prostar-500. Аналіз текстури полуниці проводили з використанням аналізатора текстур.

Результати i обговорення. Досліджено вплив комбінованого розчину метилового жасмонату (MJ), саліцилової кислоти (SA) та аскорбінової кислоти (AА) на зберігання полуничних плодів (сортів Вікторії та Камарози). Оброблення за допомогою $\mathrm{MJ}$, SA та AA позитивно вплинуло на рівень вмісту вітаміну С у плодах полуниці під час зберігання. Загальні антоціани в контрольних зразках сорту Вікторії

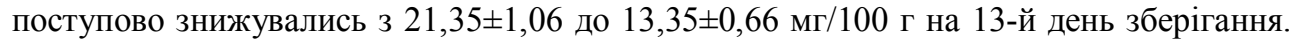
Стосовно оброблених зразків, то вміст антоціанів зменшувався до $15,49 \pm 0,77$ мг/100 г. У зразках сорту Карамоза загальний вміст антоціанів знизився 3 46,93 $\pm 2,34$ до $20,41 \pm 1,02$ і до $34,59 \pm 1,72$ мг на 100 г плодів у контрольних і оброблених зразках відповідно. Загальні фенольні сполуки (ЗФС) у контрольних зразках сорту Вікторія спочатку складали $129,86 \pm 6.49$ мг/100г, а в кінці експерименту знизилися до $111.15 \pm 5.55$ мг/100 г, у той час як у досліджуваному зразку ЗФС залишалися незмінними. ЗФС в Карамоза спочатку були на 40\% більше, ніж у Вікторії, тобто складали 181,51 $\pm 9,07$ мг/100 г. Після 13 діб зберігання ЗФС зменшувалися до $131,00 \pm 6,55$ та до $150,2 \pm 7,50$ мг/100 г у контрольних та оброблених зразках відповідно. Вплив обробки був статистично та практично значущим. Під час зберігання антиоксидантна активність плодів зменшувалася поступово. Зміна антиоксидантної активності оброблених зразків була менш значною, ніж у необробленому зразку, тобто на 17,9 та 23,3\% для плодів сортів Вікторія та Камароса відповідно. Основним антоціаніном у плодах обох сортів був пеларгонідин-3-Оглюкозид. Його початковий вміст у плодах становив 68,45 $\pm 3,42$ і $65,28 \pm 3,26 \%$ від загальної кількості антоціанів для сортів Вікторії та Камарози відповідно.

Висновок. Обробка фруктів суниці за допомогою комбінованих розчинів метилжасмонату, саліцилової кислоти та аскорбінової кислоти позитивно вплинула на зберігання плодів. Вмісту антоціанів та загальних фенолів, а також антиоксидантного потенціалу протягом періоду зберігання було значно підвищено. 
Оброблення комбінованим розчином призвело до поліпшення текстури плодів під час процесу зберігання.

Ключові слова: полуниия, фенол, антиоксидант, антоиіан, метилжасмонат, саліцилова кислота, аскорбінова кислота.

\title{
Формування функціонально-технологічних властивостей фаршів 3 яловичини 3 використанням харчової добавки на основі нанопорошку подвійного оксиду дво- та тривалентного заліза
}

\author{
Ірина Цихановська ${ }^{1}$, Людмила Скуріхіна ${ }^{2}$, \\ Вікторія Свлаш ${ }^{2}$, Лариса Павлоцька ${ }^{2}$ \\ 1 - Українська інженерно-педагогічна академія, Харків, Украӥна, \\ 2 - Харківський державний університет харчування та торгівлі, Харків, Украӥна
}

Вступ. Досліджено вплив харчової добавки на основі нанопорошку подвійного оксиду дво- та тривалентного заліза на показники якості й технологічні властивості м'ясних фаршів з яловичини.

Матеріали і методи. М'ясні фарші з яловичини, в які додавали нанопорошок подвійного оксиду дво- та тривалентного заліза у кількості $0,05-0,15 \%$. Волого- та жироутримувальну здатність визначали за допомогою жироміра та рефрактометра; стійкість фаршевих емульсій - методом центрифугування; ступінь пенетрації та граничне напруження зсуву - на конусному пластомірі; липкість - за величиною зусилля розділення двох поверхонь, зв'язаних фаршем.

Результати і обговорення. За рахунок великого питомого об'єму, спорідненості до білків, бактеріостатичності, високого хімічного потенціалу і термостабільності нанопорошок подвійного оксиду дво- та тривалентного заліза має сорбційні, комплексоутворюючі, емульгуючі, вологозв'язуючі, водо- i жироутримувальні властивості. Тому сприяе формуванню нових функціонально-технологічних показників м'ясних фаршевих систем i покращенню споживчих характеристик одержаних з них готових виробів.

Введення харчової добавки на основі нанопорошку подвійного оксиду дво- та тривалентного заліза у фарші з яловичини у кількості $0,05-0,15 \%$ до маси м'яса сприяє покращенню органолептичних (на 1,0-1,2 бала за 9-бальною шкалою) та функціонально-технологічних показників порівняно 3 контролем: вологоутримувальна здатність збільшується на $1,1-2,0 \%$; жироутримувальна здатність - на 1,2-2,6\%; емульгуюча здатність - на 1,3-2,0\%; стабільність або стійкість фаршевих емульсій - на 1,4-2,1\%. Також сприяє зменшенню рівня загального мікробного забруднення $36,2 \times 10^{5} \mathrm{KУO} /$ - у контролі до $(5,1-5,8) \times 10^{5}$ $\mathrm{KУO/г} \mathrm{у} \mathrm{зразках,} \mathrm{збагачених} \mathrm{Fe}_{3} \mathrm{O}_{4}$, тобто на 6,5-19,6\%. Втрати при термообробці дослідних зразків охолоджених фаршів з додаванням 0,05-0,15\% $\mathrm{Fe}_{3} \mathrm{O}_{4}$ зменшуються на $14,4-18,4 \%$.

Раціональна кількість харчової добавки на основі нанопорошку подвійного оксиду дво- та тривалентного заліза - $0,1 \%$ до маси м'ясної сировини.

Висновки. Харчова добавка на основі нанопорошку подвійного оксиду дво- та тривалентного заліза покращує якість i технологічні характеристики м'ясних фаршевих систем.

Ключові слова: м'ясо, фари, оксид заліза, якість. 


\title{
Хімічний склад листя гуньби сінної
}

\author{
Віра Оболкіна ${ }^{1}$,Тамара Носенко ${ }^{1}$, Ольга Дзигар ${ }^{1}$, Джамал Рахметов \\ 1 - Національний університет харчових технологій, Київ, Украӥна \\ 2 - Національний ботанічний сад імені М. М. Гришка НАН, Київ, Украӥна
}

Вступ. Досліджено хімічний склад листків гуньби сінної, яка $є$ джерелом біологічно-активних речовин і використовується як пряно-ароматична сировина в кондитерських виробах.

Матеріали і методи. Дослідження хімічного складу проводили методами: ультрашвидкісної високоефективної рідинної хроматографії; спектроскопії; газової хроматографії з мас-селективним детектуванням. Для дослідження складу агліконів екстрактів листя було використано кислотний гідроліз. Після проведення гідролізу, аглікони екстрагували етиацетатом, екстракти використовували для хроматографічного аналізу. Для ідентифікації компонентного складу було використано метод дериватизації.

Результати і обговорення. У складі листків гуньби сінної підтверджено наявність фенольних сполук, фенолкарбонових кислот, хлорофілу, алкалоїду тригонеліну, які мають високий антиоксидантний потенціал. 3 літературних джерел відомо, що фенольні сполуки у рослинах рідко зустрічаються у вільному стані. Більшість їх представлено у вигляді різноманітних О- і С-глікозидів. Різноманіття флавоноїдних глікозидів обумовлено значним набором цукрів i можливостями приєднання їх як агліконів, а також тим, що цукри можуть мати різну конфігурацію глікозидних зв'язків. У процесі досліджень ідентифіковані: луксоза, бета-dlарабінопіраноза, сукроза (цукроза), рафіноза, гліцерин, ксилітол. Доведено наявність амінокислот: L-аланіну, L-валіну, L-проліну, L-треоніну. Ідентифіковані також оксооцтова кислота; сукцинова кислота; 2, 3-діоксипропанова кислота; 2, 3, 4тригідроксимасляна кислота; пальмітинова кислота; альфа-ліноленова кислота.

Ефірна олія гуньби містить: гексадецен, ейкосанол, етилпальмінат, етиллінолат; ліноленову, бета-гідроксимасляну, бета-аміноізомасляну, гідроксибутандикарбонову, 1, 2, 3-пропантрикарбонову кислоти; етилові ефіри ліноленової, левулінової, пальмітинової, етилпальмітинової, лимонної кислот, які, ймовірно, формують флейвор пряно-ароматичної сировини.

Висновки. Наявність у листках гуньби фенольних сполук, есенціальних нутрієнтів, ароматичних речовин має сприяти подовженню терміну придатності, підвищенню харчової цінності, поліпшенню органолептичних властивостей кондитерських виробів.

Ключові слова: гуньба сінна, листя, прянощі, аромат, фенол.

\section{Зміна холестерину та вміст вільних жирних кислот у сирі Карс Груєр (турецький молочний продукт, вироблений традиційним способом)}

\author{
Ася Четінкая ${ }^{1}$, Фатіх $\mathrm{O}_{3}^{2}$ \\ 1 -Кафказький університ, Карс, Туреччина \\ 2 - Університет «Ататурк», Ерзурум, Туреччина
}

Вступ. Проведено дослідження змін співвідношення вільних жирних кислот та холестерину в сирі Карс Грейвер, виготовленому у традиційний спосіб, залежно від 
тривалості дозрівання, а також жирнокислотного складу і рівня холестерину залежно від тривалості дозрівання сиру.

Матеріали і методи. Вміст жиру у зразках сиру визначали методом Гербера. Для ідентифікації окремих жирних кислот i визначення вмісту холестерину використовували хроматографію з пламенево-іонізаційним детектуванням (GC/FID).

Результати і обговорення. Встановлено, що вміст жиру у зразках сиру Карс Гравіер становить 27,0-38,50\%. Масова частка холестерину в зразках сиру коливається від 45,70 до 55,80 мг/100 г під час дозрівання протягом 90 днів. У зразках сиру Карса Грав'єра виявлено 16 насичених і ненасичених жирних кислот. Також було зазначено, що у зразках сиру Гравієра вміст летких жирних кислот (масляної кислоти та міристинової кислоти) збільшується до 25-го дня $(\mathrm{P}<0,01)$ i зменшується з 45-го дня до 90-го дня. Вміст вільних жирних кислот (пальмітинова i лінолева кислоти) загалом зменшуються до 25-го дня, а потім знову починає збільшуватися і зростає до кінця періоду дозрівання. Після 90 днів зберігання сиру Карса Грав'єра вміст пальмітинової, олеїнової, мірістичної та стеаринової кислот становить близько 74,29\% від загальної кількості вільних жирних кислот. У досліджуваних зразках основними насиченими жирними кислотами $\epsilon$ пальмітинова та стеаринова кислоти. Було показано, що олеїнова кислота - домінуюча ненасичена жирна кислота. У зразках сиру вміст мононенасичених жирних кислот (MUFA) i поліненасичених жирних кислот (PUFA) становить 28,38-32,37\% і 1,59-1,84\%, відповідно. Для зразка сиру Карса Гравіера індекс атерогенності (AI) становить 2,573,04 .

Висновок. Жирні кислоти є попередниками ароматичних сполук, таких як вільні леткі жирні кислоти 3 коротким і середнім ланцюгом, а також етилкетони, етери та тіоетери, що утворюються в сирі внаслідок перебігу різноманітних біохімічних процесів. Наявність значної кількості жирних кислот 3 короткими та середніми ланцюгами є причиною аромату сиру Гравіер.

Ключові слова: сир, груєр, холестерин, жирні кислоти.

\title{
Ідентифікація бджолиного воску та його фальсифікату методом інфрачервоної спектроскопії
}

\author{
Володимир Вишняк ${ }^{1}$, Олег Дімітрієв², \\ Світлана Літвинчук ${ }^{1}$, Валерій Домбровський ${ }^{3}$ \\ 1 - Національний університет харчових технологій, Київ, Україна \\ 2 - Інститут фізики напівпровідників імені В. С. Лашкарьова НАН Украӥни, Київ \\ 3 - ТОВ «Київоблбджолопром», Боярка, Украӥна
}

Вступ. Визначення спектральних особливостей природного бджолиного воску методами інфрачервоної (ІЧ) спектроскопії відбивання та поглинання 3 метою виявлення наявності вуглеводневих домішок, зокрема парафіну та церезину.

Матеріали та методи. Натуральний бджолиний віск, парафін, церезин, а також їх суміші досліджувалися методом інфрачервоної спектроскопії відбивання та поглинання за допомогою спектрометрів Infrapid-61, Luminar 5030 та SPECORD M80.

Результати та обговорення. Інфрачервоні спектри відбивання від гладких поверхонь зразків (парафін, церезин, віск, суміш бджолиного воску та церезину, суміш воску парафіну та церезину, суміш воску та парафіну) мають подібну 
структуру. Спостерігаються два явно виражені максимуми на довжинах хвиль 1510 та 1581 нм. Співвідношення $\mathrm{R}_{\mathrm{w}(1581)} / \mathrm{R}_{\mathrm{W}(1510)}$ змінюється у діапазоні від 1,115 до 1,265. Найменше значення відповідає натуральному бджолиному воску, а максимальне значення - церезину. Після подрібнення зразка інфрачервоні спектри дифузного відбивання не зазнали суттєвих змін, найбільш інтенсивні спектральні максимуми не змінили свого положення, але відбувся перерозподіл спектральних ліній за інтенсивністю. Чітко виражені відмінності в області від 1723 до 2400 нм. Коефіцієнт $\alpha$ для спектрів відбивання від гладкої поверхні становив 1,2 , а для спектрів відбивання від подрібнених зразків 1,1. Відмінності спектрів відбивання в області спектра від 1100 до 1350 нм проявляються на довжині хвилі 1212,5 нм.

Спектри ІЧ-спектра дали змогу з'ясувати різницю між природним бджолиним воском і церезином через співвідношення характеристик відбиття при 1510 та 1581 нм: максимальне відношення відповідало воску, а найменше відношення - церезину. Різні пропорції смуг, що відповідають валентним коливанням $\mathrm{CH}_{2}$ та $\mathrm{CH}_{3}$, показали, що вуглеводневі ланцюжки молекул воску довші, ніж молекули досліджуваних парафіну та церезину. Встановлено, що вуглеводневі домішки в бджолиному воску асоціюються із звуженням смуги $\mathrm{C}=\mathrm{O}$ при $\sim 1736 \mathrm{~cm}^{-1}$.

Висновки. Виявлені спектральні закономірності дадуть змогу ідентифікувати натуральний бджолиний віск і виявити його фальсифікат.

Ключові слова: віск, парафін, церезин, спектроскопія, фальсифікат.

\title{
Протимікробні властивості модельних препаратів у системній концепції здоров'я
}

\author{
Микола Осейко ${ }^{1}$, Василь Шевчик ${ }^{2}$, Олена Покришко ${ }^{3}$ \\ 1 - Національний університет харчових технологій, Київ, Украӥна \\ 2- "Мікрохірургія очей Василя Шевчика", Чернігів, Украӥна \\ 3 - Тернопільський державний медичний університет імені I. Я. Гробачевського \\ Міністерства охорони здоров'я Украӥни, Тернопіль, Україна
}

Вступ. Ми проаналізували протимікробну ефективність досліджуваних препаратів серії КТІОЛ-БФ на стандартних культурах мікроорганізмів: S. aureus, Escherichia coli, P. aeruginosa та S. saprophyticus.

Матеріали та методи. Досліджуються модельні препарати серії КТІОЛ-БФ (біологічно функціональні). Препарати створені на основі рослинних і тваринних екстрактів, що містять розчин йоду або не містять його. Як контроль використано препарати повідон-йод та хлорофіліпт. Протимікробні властивості зразків препаратів визначили за модифікованим методом дифузії ("стінний" метод) щодо збільшення верхнього діапазону оцінювання.

Результати і обговорення. Науковим підгрунтям дослідження є системна концепція здоров'я, що розроблена на основі еколого-технологічної системи KTIOL-I i фізіологічно функціональної системи KTIOL-II. Препарат на основі рослинного екстракту забезпечив початковий хороший протимікробний ефект на всі досліджувані мікроорганізми. Введення до препарату на основі екстрактів рослин і на основі рослинних та тваринних екстрактів 3 розчином нанорозмірних часток колоїдного срібла до 35 мас. \% трохи зменшило протимікробну дію зразків щодо S. aureus i S. Saprophyticus. Зразок на основі рослинних і тваринних екстрактів показав гарний протимікробний ефект на мікроорганізми S. Saprophyticus, E. coli, P. 
aeruginosa. Зразки показали хороший протимікробний ефект на всі досліджувані мікроорганізми.

Модельні зразки препарату на основі двофазних рослинних модифікованих екстрактів забезпечили дуже добру інтегральну протимікробну дію на всі досліджувані мікроорганізми. Із них два зразки на основі екстрактів рослин та на основі рослинних і тваринних екстрактів виявили високу протимікробну дії на штам кишкової палички (діаметр затримки росту 30 мм).

Підтверджена можливість високої антимікробної дії на штам E. coli (затримка зростання діаметра 30 мм). Це пов'язано з комплексною дією цих двох зразків на досліджувані грампозитивні і грамнегативні штами мікроорганізмів.

Висновки. Виявлена та підтверджена можливість високої протимікробної активності зразків на основі двофазного рослинного екстракту та на основі рослинного екстракту і розчину йоду на штам Escherichia coli. Ті ж самі зразки показали високі та хороші протимікробні властивості як на інших штамах, так і інтегрально.

Ключові слова: КТІОЛ, мікроорганізм, резистентність, E. coli, антимікробний, здоров'я.

\section{Дослідження функціонально-технологічних властивостей білкового композиту тваринного походження}

Наталя Поварова, Людмила Мельник Одеська національна академія харчових технологій, Одеса, Україна

Вступ. Метою дослідження $є$ вивчення функціональних i технологічних властивостей отриманих білкових композицій із м'яса птиці та визначення оптимальної з високими показниками якості.

Матеріали і методи. Досліджується м'ясо механічного обвалювання птиці, філейна частина птиці, окорок із шкурою, яке піддавалося мікрохвильовому вакуумному сушінню 3 вологістю не більше 5\%, готові зразки Mepro 85 (голландського виробника) - тваринні білки великої рогатої худоби та Sunprotein рослинний білок.

Результати і обговорення Отримані результати свідчать про те, що отримані сухі порошки дають змогу наблизити готовий продукт до продукту зі збалансованим складом, високої якості і харчової цінності. Досліджено, що зразки 3 філейної частини, окорок курячий та м'ясо механічного обвалювання містили більше вільної вологи 80-96\%, що надає продукту з його використанням більшої соковитості і ніжної консистенції.

При цьому найкраща водоутримувальна здатність у зразка 3 філейної частини $10,2 \%$ та у Sunprotein - 11,4\%. Найбільшу жироутримувальну здатність мало м'ясо механічного обвалювання птиці - 13,1\%, якщо порівняти із зразком Mepro 85 $5,25 \%$. Емульсійна здатність у зразку м'ясо механічного обвалювання птиці становить 73\%, що на 20-25\% вище порівняно з іншими зразками.

У результаті проведення мікробіологічних досліджень не було виявлено бактерій групи кишкової палички, патогенних мікроорганізмів, в тому числі роду Сальмонела, сульфітредукуючих клостридій. Загальна кількість мікроорганізмів після сушіння у всіх зразках не перевищує норматив для вареного сушеного м'яса $\left(5 \times 10^{3)}\right.$. Найкращий результат порівняно з іншими спостерігався у зразку Sunprotein $-1,8 \times 10^{3}$. 
При сенсорному аналізі встановлено, що зразок із філейної частини має кращий зовнішній вигляд і запах, тоді як у м'яса механічного обвалювання консистенція краща. Вона найбільш розсипчаста, притаманна сухим порошкам.

Висновки. Порівняльний аналіз підтверджує високі функціональні й технологічні властивості зразків із філейної частини птиці і м'яса механічного обвалювання птиці, а також є безпечними при застосуванні у м'ясних продуктах.

Ключові слова: м'ясо, білок, птичя, добавка, сушіння.

\section{Біотеннологія, мікробілогія}

\section{Визначення, характеристика і промислова утилізація автохтонних штамів Streptococcus thermophilus, виділених 3 молдовського сирого молока і молочних продуктів спонтанного бродіння}

Анатолій Карташев

Науково-практичний інститут садівництва, виноградарства і харчових технологій, Кишинеу, Молдова

Вступ. Молочнокислі бактерії з відомими метаболічними властивостями визначають сенсорні характеристики продуктів, забезпечують їх якість і безпеку. Обмежена кількість високобіотехнологічно доступних штамів і постійний ризик нападів бактеріофагових атак виправдовують необхідність нових штамів.

Матеріали і методи. Визначення термофільних молочнокислих бактерій здійснювалось на основі фенотипічних властивостей і використанням молекулярних методів - RAPD-ПЛР та ФТРР-спектроскопії. Антагоністична активність відібраних штамів проводилася дифузійним методом. Порівняння стартерної культури та зразків йогурту виконувалося за традиційними технологіями.

Результати і обговорення. Вибрані штами $S$. thermophilus характеризуються інтенсивним підкисленням молока протягом 3-4 годин, розвиваючи молочну кислотність 65-74 ${ }^{\circ} \mathrm{T}$ та утворюючи однорідний компактний щільний коагул, що забезпечує його тверду консистенцію. Штами $S$. thermophilus штамів CNMN-LB-50 i CNMN-LB-51 здатні синтезувати екзополісахариди (ЕПC).

Антагоністична активність протипатогенних мікроорганізмів штамів Росії висока. Діапазон інгібуції від 16 до 18 мм від Escherichia coli. і 19-21 мм на Staphylococcus aureus, який пригнічує розвиток кишкових інфекцій i запобігає розвитку патогенів у зразках ферментованого молока. Максимальний сигнал EPS, синтезований за субоптимальної температури $32{ }^{\circ} \mathrm{C}$, на $19,4 \%$ вище, ніж за оптимальної температури для цього процесу $\left(40{ }^{\circ} \mathrm{C}\right)$ для штамів S. thermophilus CNMN-LB-50 i 23,8\% для S. thermophilus CNMN-LB-51. Щоб стимулювати синтез ЕПС у промислових умовах виробництва кисломолочних продуктів без зміни температури, поживне середовище повинно бути доповнене сахарозою у кількості $8 \%$.

Висновки. Продемонстровано можливість отримання 3 мікрофлори сирого молока i молочних продуктів спонтанного бродіння автохтонних штамів молочнокислих бактерій з цінними біотехнологічними властивостями, призначених для використання в складі заквасок для виробництва ферментованих молочних продуктів.

Ключові слова: Streptococcus thermophilus, молоко, бродіння, ідентифікація. 


\title{
Харчова безпека
}

Оцінка концентрації важких металів у їстівних риб'ячих м'язах та зразках води, зібраних з різних локацій біля Читтагонгу: проблема охорони здоров'я

\author{
Яакія Султана Йотхі ${ }^{1,3}$, Ішрат Захан Анка ${ }^{1}$, \\ Шахаріор Хашем ${ }^{2,3}$, Шамсул Моршед ${ }^{1}$ \\ 1 - Читтагонгський університет ветеринарних і тваринницьких наук, Читтагонг, \\ Бангладеш \\ 2 - Бангладешський аграрний університет, Бангладеш \\ 3 - Хіросімський університет, Японія
}

Вступ. Проведено дослідження концентрації важких металів у зразках риби та води, зібраних із різних районів Читтагонгского району, Бангладеш.

Матеріали та методи. Концентрації важких металів, включаючи $\mathrm{Cr}, \mathrm{Cu}, \mathrm{Ni}, \mathrm{Pb}$ та $\mathrm{Fe}$ у морській воді та морських рибах (пам-крокер, бомбейська качка і анчоус) виявлені за допомогою атомно-абсорбційного спектрометра у районі міста Читтагонг, Бангладеш.

Результати та обговорення. Середня концентрація важких металів була виявлена у воді в діапазоні $\mathrm{Cr}$ 0,01338-0,0789 мг/л, Cu 0,0014-0,0284 мг/л, Ni 0,0259-0,2519 мг/л, $\mathrm{Pb}$ 0,0109-0,1596 мг/л, i Fe 0,2176-1,787 мг/л. Аналіз зразків води показав, що розподіл важких металів в порядку величини, виглядає так: $\mathrm{Fe}>\mathrm{Ni}>\mathrm{Pb}>\mathrm{Cr}>\mathrm{Cu}$. Різниця може бути пов'язана 3 розташуванням локацій, рівнем забруднення у воді через промислові стоки та антропогенні види діяльності. Хоча середня концентрація важких металів була виявлена у всіх зразках риби в діапазоні $\mathrm{Cr} 3.2039-16.3495$ мг/кг сухої маси, $\mathrm{Cu}$ 1.5589-4.5848 мг/кг сухої маси, Ni 0.1101-1.9029 мг/кг сухої маси, Рb 0.4373-2.7638 мг/кг сухої маси і Fe 30,9599-108,780 мг/кг сухої маси. Розподіл важких металів у зразках риби виглядає так: $\mathrm{Fe}>\mathrm{Cr}>\mathrm{Cu}>\mathrm{Pb}>\mathrm{Ni}$. Аналіз показав, що величини важких металів були більш-менш схожі $з$ даними інших дослідників. Різниця може бути пов'язана із накопиченням металів у рибі та різноманітних видах риб, що живуть у одній водоймі, але різного рівня забруднення у воді. Серед усіх зразків 17\% зразків риби мали надлишок $\mathrm{Cr}$, в той час як прийнятна межа дорівнює 15.0 мг/кг для риб. Середні концентрації $\mathrm{Pb}$ у всіх рибних зразках були на 17\% нижче рівня виявлення, $33 \%$ - оптимальні та $33 \%$ - вищі, ніж максимально дозволені концентрації $(1,5$ мг/кг). Fe у всіх рибних зразках був на $33 \%$ нижчим, $17 \%$ оптимальним і 50\% - вищим, ніж максимально дозволені концентрації (43 мг/кг), рекомендовані ФАО/ВООЗ.

Висновки. Більшість досліджених видів риб є безпечними для споживання. Тому це дослідження спрямоване привернути увагу органів охорони здоров'я та охорони навколишнього середовища до потреб відповідної регуляторної бази.

Ключові слова: важкий метал, вода, море, морська риба, Чіттагонг. 


\title{
Процеси і обладнання
}

\section{Інтенсифікація охолодження рукавних полімерних пакувальних плівок стічною плівкою рідини}

\author{
Ігор Мікульонок ${ }^{1}$, Аркадій Пєтухов ${ }^{1}$, Віктор Гапон $^{1}$, Олександр Гавва ${ }^{2}$ \\ 1 - Начіональний технічний університет Украйни «Київський політехнічний \\ інститут імені Ігоря Сікорського», Київ, Украӥна \\ 2 - Національний університет харчових технологій, Київ, Украӥна
}

Вступ. Проведено аналітичні й натурні дослідження процесу охолодження пакувальної плівки з поліетилену високого тиску (ПЕВТ) стічною водяною плівкою.

Матеріали і методи. Експериментальні дослідження охолодження плівки проведені за таких параметрів: тип плівки - плоска; швидкість руху плівки - 0,03$0,50 \mathrm{~m} / \mathrm{c}$; розміри щілинного розподільника водяної плівки: величина щілини - 0,40,8 мм, ширина щілини - 300 мм; температура охолодної води - 15-40 ${ }^{\circ} \mathrm{C}$. Раціональні параметри процесу охолодження визначені на основі математичного моделювання.

Результати і обговорення. Параметри рідинної плівки змінюються тільки на вхідній ділянці й залежать від щільності зрошення, швидкості полімерного рукава й початкового розподілу швидкості плівки рідини на виході з розподільного кільця. За високих значень щільності зрошення $(\mathrm{Re}>20000)$ у теплообміні бере участь лише пристінний шар рідини.

Для плівки з поліетилену високого тиску іï зовнішня поверхня твердне на відстані близько 0,01 м від початку контакту з водою, а внутрішня поверхня - на відстані близько 0,10-0,15 м. Тому кільце для розподілу рідини необхідно встановлювати після закінчення ділянки роздуву заготовки полімерного рукава. Також потрібно забезпечити стійкий рух суцільної плівки рідини по зовнішній поверхні полімерного рукава на довжині до 0,2 м від початку контакту рідини 3 полімерною плівкою.

Температура охолодної води в діапазоні $20-60{ }^{\circ} \mathrm{C}$ істотно не впливає як на інтенсивність процесу охолодження, так і на фізико-механічні властивості одержуваної полімерної плівки.

Для товстих плівок з ПЕВТ (завтовшки понад 200 мкм) і завширшки понад 1 м інтенсивність охолодження обмежена критичною щільністю зрошення.

Для практичного застосування отриманих результатів запропоновано номограму для визначення об'ємної щільності зрошення охолодної води, а також об'ємної продуктивності технологічної лінії залежно від розмірів готового полімерного рукава.

Висновки. Наукове значення результатів полягає у визначенні раціональних умов застосування рідинного охолодження одержуваних екструзією рукавних полімерних плівок.

Ключові слова: упаковка, полімер, екструзія, плівка, охолодження. 


\title{
Вплив нанорозмірного гідроксиду алюмінію на структурно-механічні властивості бурякової тканини
}

\author{
Тарас Никитюк ${ }^{1}$, Валентин Олішевський ${ }^{1}$, Свген Бабко $^{1}$, Олег Прокопюк ${ }^{2}$ \\ 1 - Національний університет харчових технологій, Київ, Украӥна \\ $2-$ ТОВ «Теплоком»
}

Вступ. Проведені дослідження 3 метою підтвердження доцільності використання нанорозмірного гідроксиду алюмінію в процесі екстрагування сахарози 3 бурякової стружки 3 метою підвищення структурно-механічних властивостей бурякової тканини.

Матеріали і методи. Дослідження термохімічного впливу водних розчинів додаткових реагентів на структурно-механічні властивості бурякової тканини методом гідравлічного пресування зразків тканини цукрового буряка циліндричної форми із заданими геометричними розмірами. Перед цим кожен з отриманих зразків підлягав тепловій обробці у водних розчинах різних реагентів при температурі 70-72 ${ }^{\circ} \mathrm{C}$ і тривалості досліду 60 хв.

Результати та обговорення. Обробка зразків бурякової тканини додатковими розчинами сульфату алюмінію, сульфату кальцію, нанорозмірного гідроксиду алюмінію та їх комбінаціями в процесі екстрагування при температурі 70-72 ${ }^{\circ} \mathrm{C}$ дасть змогу зменшити ступінь деформації зразків бурякової тканини порівняно зі зразком, що не піддавався обробці додатковими реагентами. Ступінь зразка бурякової тканини, що був оброблений розчином нанорозмірного гідроксиду алюмінію, на 18 \% нижчий, ніж контрольний зразок без обробки додатковими реагентами. Такий результат можна пояснити високою хімічною активністю реагенту нанорозмірного гідроксиду алюмінію. Іони цієї сполуки здатні утворювати в поверхневому шарі тканини досить стійкі нерозчинні комплексні сполуки з пектиновими і білковими речовинами, які, адсорбуючись на шарі бурякової тканини, формують щось подібне до молекулярного каркасу, що підвищує стійкість бурякової тканини до стискаючих навантажень.

Величиною, яка найточніше може описати якість бурякової тканини, є іiі здатність відновлювати свою форму та пружність при періодичних стискаючих навантаженнях, є саме: модуль пружності. При тепловій обробці за температури 70$72{ }^{\circ} \mathrm{C}$ модуль пружності зразків бурякової тканини, що піддавалася обробці додатковим реагентами, на $35-40 \%$ вищий, ніж зразок бурякової тканини без обробки додатковими реагентами.

Висновки. Застосування в процесі екстрагування нанорозмірного гідроксиду алюмінію, забезпечить збереження цілісності структури бурякової тканини в процесах екстрагування та пресування; гарантує високу якість екстрагенту, дифузійного та очищеного соку.

Ключові слова: иукровий буряк, стружка, тканина, екстрагування, нанорозмірний, гідроксид алюмінію, пружність. 


\title{
Крутильні коливання гвинтового робочого органу шнекового багатофункціонального транспортера з урахуванням динаміки суцільного потоку оброблювального середовища
}

\author{
Олег Ляшук ${ }^{1}$, Марія Сокіл ${ }^{2}$, Юрій Вовк ${ }^{1}$, \\ Анна Цьонь ${ }^{1}$, Андрій Гупка ${ }^{1}$, Олександр Марунич ${ }^{1}$ \\ 1 - Тернопільський національний технічний університет імені Івана Пулюя, \\ Тернопіль, Україна, \\ 2 - Національний університет «Львівська політехніка», Львів, Україна
}

Вступ. Метою статті є математична модель коливань робочого органу шнекового транспортера для транспортування сипких вантажів з урахуванням зміни щільності оброблюваного середовища, швидкості обертання шнека, маси при появі явища резонансу.

Матеріали і методи. Досліджуються крутильні коливання гвинтового робочого органу шнекового багатофункціонального транспортера, які виникають внаслідок дії оброблювального середовища. Дослідження проведено методом математичного моделювання.

Результати i обговорення. Основними обмежуючими факторами, які ускладнюють моделювання, $\epsilon$ нерівномірність розподілу середовища уздовж довжини шнека; тіло виконує гнучкі коливання; рух оброблюваного середовища вздовж робочого гвинта спричиняє малі коливання згину, викликає появу «додаткових сил». Для забезпечення достовірності математичної моделі введено такі припущення: робочий гвинт шнека обертається 3 постійною кутовою швидкістю навколо своєї поздовжньої осі, яка в недеформованому положенні збігається з віссю $\mathrm{OX}$; вектором визначається поперечне переміщення нейтральної осі робочого гвинта у довільному моменті в напрямку, перпендикулярному його недеформованому положенню (щодо фіксованої системи відліку OXYZ); безперервний потік обробленого середовища, маса якого на одиницю довжини повільно змінюється вздовж гвинта і рухається 3 постійною відносною (відносно робочого шнека) швидкістю.

Математична модель враховує обмеження i припущення для існуючого шнекового транспортера довжиною 2,5 i 3 м, який використовується для переміщення сипких вантажів щільністю 10, 20, 40 кг/м. Змінними параметрами є довжина шнека, щільність оброблюваного середовища, швидкість обертання шнека, мaca.

На основі моделі побудовано залежності амплітуди коливань від довжини шнека, щільності оброблюваного середовища, швидкості обертання шнека, маси.

Висновки. Математична модель дає змогу удосконалити процес розробки i проектування шнекових транспортерів сипких вантажів, забезпечуючи при цьому надійність процесу транспортування та системи «оброблюване середовищегвинтовий робочий орган».

Ключові слова: шнек, конвеєр, амплітуда, резонанс, моделювання. 


\title{
Автоматизація технологічних процесів
}

\section{Ефективна робастно-оптимальна система керування пластинчастою пастеризаційно-охолоджувальною установкою в умовах дії інтенсивних зовнішніх збурень}

\author{
Наталія Луцька ${ }^{1}$, Наталія Заєць $^{2}$, Лідія Власенко ${ }^{1}$, Володимир Штепа ${ }^{3}$ \\ 1 - Національний університет харчових технологій, Київ, Украӥна \\ 2 - Національний університет біоресурсів та природокористування Украӥни, \\ Київ, Украӥна \\ 3 - Поліський державний університет, Пінськ, Білорусь
}

Вступ. Досліджено робастно-оптимальну систему керування пастеризаційноохолоджувальною установкою, що функціонує в умовах інтенсивних зовнішніх збурень, інформаційної та структурної невизначеності, 3 метою підвищення ефективності іï функціонування.

Матеріали і методи. Методи системного аналізу, математичної статистики та ідентифікації використовуються для побудови математичної моделі об'єкта керування. Для синтезу робастно-оптимального регулятора застосовано 2-Ріккаті підхід для проблеми $\mathrm{H}_{2}$-керування, а для зменшення порядку отриманого регулятора - метод збалансованого зменшення моделі.

Результати і обговорення. Пастеризаційна установка $є$ ключовим компонентом виробництва молочної продукції. Оскільки результати роботи традиційних автоматизованих систем залежать від інтенсивності та якості інформаційних потоків, мікропроцесорної техніки, алгоритмічного та програмного забезпечення, пропонується доповнити їх робастно-оптимальним регулятором на основі 2-Ріккаті підходу. На основі визначеної математичної моделі об'єкта, що складається 3 лінійних диференціальних рівнянь сьомого порядку, синтезовано робастнооптимальний регулятор 6-го порядку. Показники ефективності розраховуються шляхом порівняння синтезованої системи та системи $з$ локальними регуляторами. У робастно-оптимальній системі розмах невизначеності збільшився в чотири рази, а дисперсія керуючих сигналів зменшилася в чотири рази, що підтверджує енергоефективність системи.

Висновок. Проведене моделювання та розрахунок якісних характеристик показали значну перевагу синтезованої системи перед системами 3 локальними регуляторами.

Ключові слова: робастний, оптимальний, 2-Ріккаті, невизначеність, $H_{2}-$ регулятор. 


\title{
Економіка і управління
}

\section{Представлення інтересів сільськогосподарських виробників: обгрунтування структури дослідження}

\author{
Агота Гієдре Райшене, Артьом Волков, \\ Віргіліус Скалскіс, Ріта Вілке \\ Литовський ініститут аграрної економіки, Вільнюс, Литва
}

Вступ. Метою статті є обгрунтування структури наукових досліджень, яка дає змогу оцінити участь сільськогосподарських виробників у процесах формування аграрної політики держави.

Матеріали і методи. Під час дослідження використовувалися методи наукового обгрунтування, аналізу, систематизації, синтезу та опитування. Теоретичне обгрунтування базується на аналізі теорій управління, що пояснює характер міжорганізаційної взаємодії.

Результати і обговорення. Представляти інтересів сільськогосподарських товаровиробників у процесі формування аграрної політики $є$ недоцільним. Як приклад для дослідження ми вибрали Литву i встановили, що 85,6\% сільськогосподарських виробників не є членами асоціацій чи об'єднань і тільки близько $10 \%$ них беруть участь у роботі сільськогосподарських організацій.

Результати дослідження показують, що відповідно до політики фінансової підтримки агропідприємств у ЄС проблема участі зацікавлених осіб в управлінні підприємством зменшує можливості великих i малих сільськогосподарських виробників захищати свої інтереси. Програма участі та спільного управління i концепція партнерської та міжорганізаційної взаємодії були узгоджені шляхом:

а) відмежування відповідних груп асоціацій сільськогосподарських виробників від участі в процесі формуванні політики галузі;

б) розроблення схеми для досягнення балансу між потребами зацікавлених осіб та асоціацій сільськогосподарських виробників;

в) формування теоретичної бази для подальшого якісного опитування всіх учасників взаємовідносин.

Під час аналізу результатів досліджень було встановлено, що досягнення інтересів, заснованих на потребах, повинне стати головним завданням для політиків. Для цього необхідно забезпечити збалансованість впливу зацікавлених сторін 3 метою врахування інтересів усіх учасників. Результати досліджень показують, що 3 метою досягнення інтересів зацікавлених осіб потрібно враховувати їхні потреби в процесі формування агрополітики товаровиробника.

Висновок. Сформована у дослідження система дає змогу систематично збирати якісні дані та подавати раціональні пропозиції політичним і сільськогосподарським організаціям.

Ключові слова: сільське господарство, фермер, управління. 


\section{Instructions for authors}

\section{Dear colleagues!}

The Editorial Board of scientific periodical

\section{"Ukrainian Food Journal"}

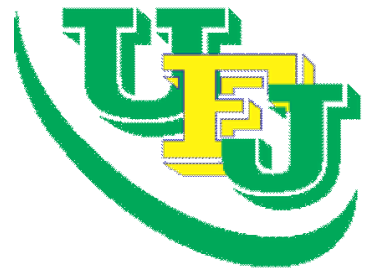

invites you for publication of your research results.

Requirements to all texts:

Language - English.

Size of the article - 10-15 pages in Microsoft Word 2003 and earlier versions with filename extension *.doc (!)

Times New Roman, font size 14, 1 line intervals, margins on both sides $-2 \mathrm{~cm}$.

The structure of the article:

1. The title of the article

2. Authors (full name and surname)

3. Institution, where the work has been performed.

4. Abstract (2/3 of a page). The structure of the abstract should correspond to the structure of the article (Introduction, Materials and methods, Results and discussion, Conclusion).

5. Keywords.

6. The main body of the article should contain the following parts:

- Introduction

- Materials and methods

- Results and discussion

- Conclusion

- References

If you need you can add another parts and/or divide them into subparts.

7. The information about the author (Name, surname, scientific degree, place of work, email and contact phone number).

All figures should be made in graphic editor, the font size 14 .

The background of the graphs and charts should be only in white color. The color of the figure elements (lines, grid, text) - in black color.

Figures and EXCEL format files with graphs additionally should be submitted in separate files.

Photos are not recommended to be used as graphical materials.

\section{Website of Ukrainian Food Journal: http://ufj.ho.ua}

\section{Email for all submissions and other inquiries: ufj_nuft@meta.ua}




\section{Шановні колеги!}

Редакційна колегія наукового періодичного видання «Ukrainian Food Journal» запрошує Вас до публікації результатів наукових досліджень.

\section{Вимоги до оформлення статей}

Мова статей - англійська.

Мінімальний обсяг статті - 8 сторінок формату А4 (без врахування анотацій i списку літератури).

Стаття виконується в текстовому редакторі Microsoft Word 2003, в форматі *.doc.

Для всіх елементів статті шрифт - Times New Roman, кегль - 14, інтервал - 1.

Всі поля сторінки - по 2 см.

1. УДК.

\section{Структура статті:}

2. Назва статті.

3. Автори статті (ім'я та прізвище повністю, приклад: Денис Озерянко).

4. Установа, в якій виконана робота.

5. Анотація. Обов'язкова структура анотації:

- Вступ (2-3 рядки).

- Матеріали та методи (до 5 рядків)

- Результати та обговорення (пів сторінки).

- Висновки (2-3 рядки).

6. Ключові слова (3-5 слів, але не словосполучень).

\section{Пункти 2-6 виконати англійською і українською мовами.}

7. Основний текст статті. Має включати такі обов'язкові розділи:

- Вступ

- Матеріали та методи

- Результати та обговорення

- Висновки

- Література.

За необхідності можна додавати інші розділи та розбивати їх на підрозділи.

8. Авторська довідка (Прізвище, ім'я та по батькові, вчений ступінь та звання, місце роботи, електронна адреса або телефон).

9. Контактні дані автора, до якого за необхідності буде звертатись редакція журналу.

Рисунки виконуються якісно. Скановані рисунки не приймаються. Розмір тексту на рисунках повинен бути співрозмірним (!) тексту статті. Фотографії можна використовувати лише за їх значної наукової цінності.

Фон графіків, діаграм - лише білий. Колір елементів рисунку (лінії, сітка, текст) - чорний (не сірий).

Рисунки та графіки EXCEL 3 графіками додатково подаються в окремих файлах.

Скорочені назви фізичних величин в тексті та на графіках позначаються латинськими літерами відповідно до системи СІ.

В списку літератури повинні переважати англомовні статті та монографії, які опубліковані після 2000 року. 


\section{Правила оформлення списку літератури}

B Ukrainian Food Journalвзято за основу загальноприйняте в світі спрощене оформлення списку літератури згідно стандарту Garvard. Всі елементи посилання розділяються лише комами.

\section{1. Посилання на статтю:}

Автори А.А. (рік видання), Назва статті, Назва журналу (курсивом), Том (номер), сторінки.

Ініціали пишуться після прізвища.

Всі елементи посилання розділяються комами.

1. Приклад:

Popovici C., Gitin L., Alexe P. (2013), Characterization of walnut (Juglans regia L.) green husk extract obtained by supercritical carbon dioxide fluid extraction, Journal of Food and Packaging Science, Technique and Technologies, 2(2), pp. 104-108.

\section{2. Посилання на книгу:}

Автори (рік), Назва книги (курсивом), Видавництво, Місто.

Ініціали пишуться після прізвища.

Всі елементи посилання розділяються комами.

Приклад:

2. Wen-Ching Yang (2003), Handbook of fluidization and fluid-particle systems, Marcel Dekker, New York.

\section{Посилання на електронний ресурс:}

Виконується аналогічно посиланню на книгу або статтю. Після оформлення даних про публікацію пишуться слова Available at: та вказується електронна адреса.

Приклади:

1. (2013), Svitovi naukovometrychni bazy, available at: http://www1.nas.gov.ua/publications/q_a a Pages/scopus.aspx

2. Cheung T. (2011), World's 50 most delicious drinks [Text], Available at: http://travel.cnn.com/explorations/drink/worlds-50-most-delicious-drinks-883542

Список літератури оформлюється лише латиницею. Елементи списку українською та російською мовою потрібно транслітерувати. Для транслітерації 3 українською мови використовується паспортний стандарт, а з російської - стандарт МВД (в цих стандартах використовуються символи лише англійського алфавіту, без хвостиків, апострофів та ін).

Зручні сайти для транслітерації:

З української мови - http://translit.kh.ua/\#lat/passport

3 російської мови $-\mathrm{http}: / /$ ru.translit.net/?account=mvd

\section{Додаткова інформація та приклад оформлення статті - на сайті http://ufj.ho.ua}

Стаття надсилається за електронною адресою: ufj_nuft@meta.ua 
Ukrainian Food Journal публікує оригінальні наукові статті, короткі повідомлення, оглядові статті, новини та огляди літератури.

\section{Тематика публікацій в Ukrainian Food Journal:}

Харчова інженерія

Харчова хімія

Мікробіологія

Фізичні властивості харчових

продуктів

Якість та безпека харчових продуктів
Процеси та обладнання

Нанотехнології

Економіка та управління

Автоматизація процесів

Упаковка для харчових продуктів

Періодичність виходу журналу 4 номери на рік.

Результати досліджень, представлені в журналі, повинні бути новими, мати чіткий зв'язок 3 харчовою наукою i представляти інтерес для міжнародного наукового співтовариства.

Ukrainian Food Journal індексується наукометричними базами:

Index Copernicus (2012)

EBSCO (2013)

Google Scholar (2013)

UlrichsWeb (2013)

Global Impact Factor (2014)

Online Library of University of Southern Denmark (2014)

CABI full text (2014)

Directory of Research Journals Indexing (DRJI) (2014)

Universal Impact Factor (2014)

Directory of Open Access scholarly Resources (ROAD) (2014)

European Reference Index for the Humanities and the Social Sciences (ERIH PLUS) (2014)

Directory of Open Access Journals (DOAJ) (2015)

InfoBase Index (2015)

Chemical Abstracts Service Source Index (CASSI) (2016)

Emerging Sourses Citaton Index (2018)

Рецензія рукопису статті. Матеріали, представлені для публікування в «Ukrainian Food Journal», проходять «Подвійне сліпе рецензування» двома вченими, призначеними редакційною колегією: один $є$ членом редколегії і один незалежний учений.

Авторське право. Автори статей гарантують, що робота не $є$ порушенням будь-яких авторських прав, та відшкодовують видавцю порушення даної гарантії. Опубліковані матеріали є правовою власністю видавця «Ukrainian Food Journal», якщо не узгоджено інше.

Політика академічної етики. Редакція «Ukrainian Food Journal» користується правилами академічної етики, викладених в роботі Miguel Roig (2003, 2006) "Avoiding plagiarism, self-plagiarism, and other questionable writing practices. A guide to ethical writing". Редакція пропонує авторам статей і рецензентам прямо слідувати цьому керівництву, щоб уникнути помилок у науковій літературі.

Інструкції для авторів та інша корисна інформація розміщені на сайті http: / / ufj.ho.ua 


\section{Редакційна колегія}

Головний редактор:

Валерій Манк, д-р. техн. наук, проф., Національний університет харчових технологій, Украӥна

\section{Члени міжнародної редакційної колегії:}

Валерій Мирончук, д-р. техн. наук, проф., Начіональний університет харчових технологій, Україна

Віктор Стабніков, канд. техн. наук, доц., Національний університет харчових технологій, Украӥна

Віргінія Юренієнє, д-р., проф., Вільнюський університет, Литва

Володимир Іванов, д-р., проф., Державний університет Іови, США

Владімір Груданов, д-р. техн. наук, проф., Бєларуський державний аграрний технічний університет

Йорданка Стефанова, д-р, Пловдівський університет "Паісій Хілендарскі", Болгарія Крістіна Попович, д-р., доц., Технічний університет Молдови

Марк Шамцян, канд. техн. наук, доц., Санкт-Петербурзький державний технологічний інститут, Росія

Лелівельд Хуб,, асоиіачія «Міжнародна гармонізаційна ініціатива», Нідерланди

Паскаль Дюпьо, д-р, Університет Клод Бернард Ліон 1, Франиія

Семіх Отлес, д-р., проф, Університет Еге, Туреччина

Соня Амарей, д-р., проф, Університет «Штефан чел Маре», Сучава, Румунія

Стефан Стефанов, д-р., проф., Університет харчових технологій, Болгарія

Тетяна Пирог, д-р. біол. наук, проф., Національний університет харчових

технологій, Украӥна

Томаш Бернат, д-р., проф., Щецинський університет, Польщза

Юлія Дзязько, д-р. хім. наук, с.н.с., Інститут загальної та неорганічної хімії імені B. I. Вернадського НАН Украӥни

Юрій Білан, д-р., Щецинський університет, Польщза

\section{Члени редакційної колегії:}

Анатолій Сайганов, д-р. екон. наук, проф., Інститут системних досліджень в АПК НАН Беларусі

Валерій Мирончук, д-р. техн. наук, проф., Наџіональний університет харчових технологій, Украӥна

Віктор Стабніков, канд. техн. наук, доц., Національний університет харчових технологій, Украӥна

Віргінія Юренієнс, д-р., проф., Вільнюський університет, Литва

Володимир Ковбаса, д-р. техн. наук, проф., Національний університет харчових технологій, Украӥна

Володимир Іванов, д-р., проф., Державний університет Іови, США 
Владімір Груданов, д-р. техн. наук, проф., Бєларуський державний аграрний технічний університет

Галина Сімахіна, д-р. техн. наук, проф., Національний університет харчових технологій, Украӥна

Йорданка Стефанова, д-р, Пловдівський університет "Паісій Хілендарскі", Болгарія Крістіна Попович, д-р., доц., Технічний університет Молдови

Лада Шерінян, д-р. екон. наук, професор., Національний університет харчових технологій, Украӥна

Марк Шамцян, канд. техн. наук, доц., Санкт-Петербурзький державний технологічний інститут, Росія

Микола Сичевський, д-р. екон. наук, проф., Інститут продовольчих ресурсів НААН Украӥни

Лелівельд Хуб, асоиіація «Міжнародна гармонізаційна ініціатива», Нідерланди

Олександр Шевченко, д-р.техн. наук, проф., Національний університет харчових технологій, Украӥна

Олена Грабовська, д-р. техн. наук, проф., Національний університет харчових технологій, Украӥна

Олена Драган, д-р. екон. наук, проф., Національний університет харчових технологій, Украӥна

Ольга Рибак, канд. техн. наук, доц., Тернопільський національний технічний унівреситет імені Івана Пулюя, Україна

Паскаль Дюпьо, д-р, Університет Клод Бернард Ліон 1, Франція

Семіх Отлес, д-р., проф, Університет Еге, Туреччина

Соня Амарей, д-р., проф, Університет «Штефан чел Маре», Сучава, Румунія

Стефан Стефанов, д-р., проф., Університет харчових технологій, Болгарія

Тамара Березянко, д-р. екон. наук, проф., Національний університет харчових технологій, Украӥна

Тетяна Пирог, д-р. біол. наук, проф., Національний університет харчових технологій, Україна

Томаш Бернат, д-р., проф., Щецинський університет, Польщза

Юлія Дзязько, д-р. хім. наук, с.н.с., Інститут загальної та неорганічної хімії імені В. I. Вернадського НАН України

Юрій Білан, д-р., Щецинський університет, Польщза

Олексій Губеня (відповідальний секретар), канд. техн. наук, доц., Національний університет харчових технологій, Украӥна. 


\section{Ukrainian Food Journal}

\section{Volume 7, Issue 3 2018}

\section{Tом 7, № 3 \\ 2018}

Підп. до друку 28.09.2018 р. Формат 70x100/16.

Обл.-вид. арк. 15.36. Ум. друк. арк. 14.98 .

Гарнітура Times New Roman. Друк офсетний.

Наклад 100 прим. Вид. № 12н/18.

НУХТ. 01601 Київ-33, вул. Володимирська, 68

Свідоцтво про державну реєстрацію друкованого засобу масової інформації

KB 18964-7754P

видане 26 березня 2012 року. 